Portland State University

PDXScholar

\title{
Telling Stories (Out of School) of Mother Tongue, God's Tongue, and the Queen's Tongue: An Ethnography in Canada
}

Joan Ratzlaff Swinney

Portland State University

Follow this and additional works at: https://pdxscholar.library.pdx.edu/open_access_etds Let us know how access to this document benefits you.

\section{Recommended Citation}

Swinney, Joan Ratzlaff, "Telling Stories (Out of School) of Mother Tongue, God's Tongue, and the Queen's Tongue: An Ethnography in Canada" (1991). Dissertations and Theses. Paper 1240.

https://doi.org/10.15760/etd.1239

This Dissertation is brought to you for free and open access. It has been accepted for inclusion in Dissertations and Theses by an authorized administrator of PDXScholar. Please contact us if we can make this document more accessible: pdxscholar@pdx.edu. 
TELLING STORIES (OUT OF SCHOOL)

OF MOTHER TONGUE, GOD'S TONGUE, AND THE QUEEN'S TONGUE:

\title{
AN ETHNOGRAPHY IN CANADA
}

by

JOAN RATZLAFF SWINNEY

A dissertation submitted in partial fulfillment of the requirements for the degree of

\author{
DOCTOR OF EDUCATION \\ in \\ EDUCATIONAL LEADERSHIP
}

Portland State University

(C) 1991 


\section{TO THE OFFICE OF GRADUATE STUDIES:}

The members of the Committee approve the dissertation of Joan Ratzlaff Swinney presented June 24, 1991.
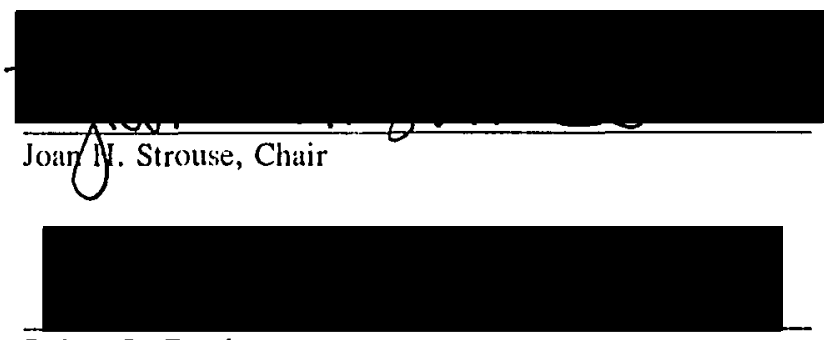

Robert B. Everhart
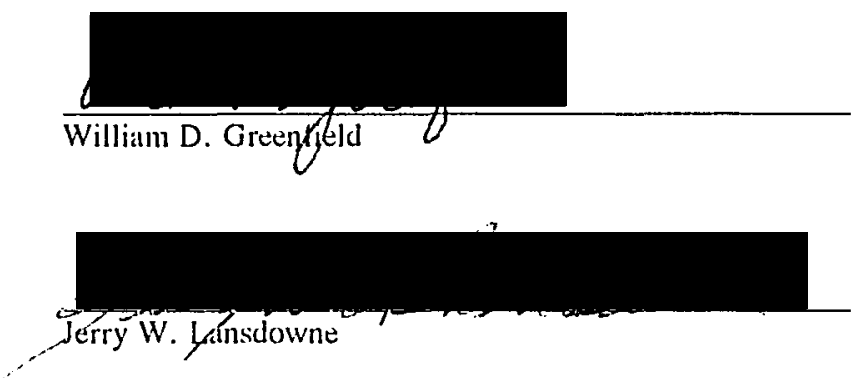

APPROVED:

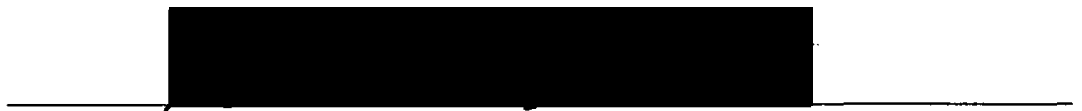

Robert B. Everhart, Dean, School of Education

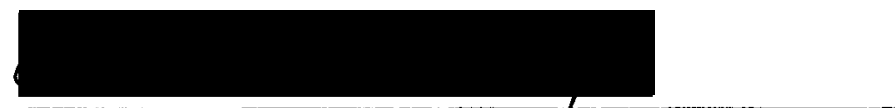

C. William Savery, Vice Provost for Graduate Studi Sand Research 
AN ABSTRACT OF THE DISSERTATION OF Joan |Ratzlaff Swinney for the Doctor of Education in Educational Leadership presented June 24, 1991.

Title: Telling Stories (Cut of School) of Mother Tonguc, God's Tongue, and the Queen's Tongue: An Ethnography in Canada

APPROVED BY THE MEMBERS OF THE DISSERTATION COMMITTEE:

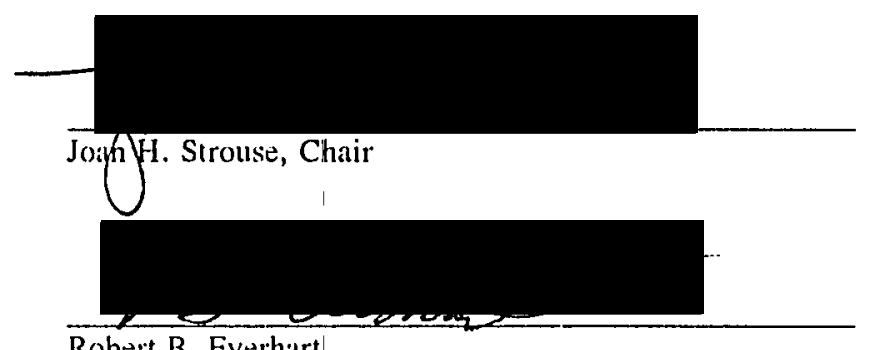

Robert B. Everhart
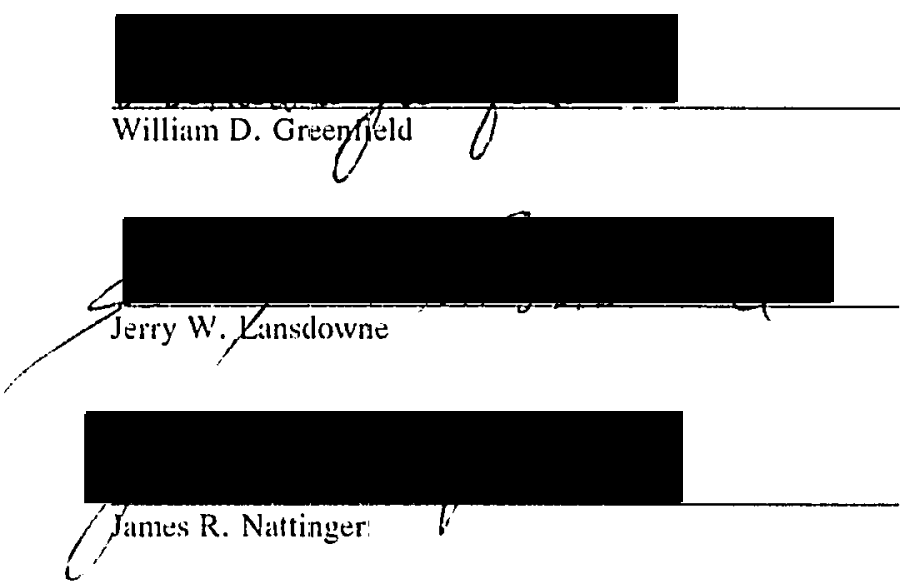

Histories give little attention to language dominance in school and community -- to the fact that the past one-hundred years of "One: People, One Language, One School" attitudes, policies, and goals in Anglo-American schools and communities have brought with them the demise of Native-Anerican languages, the disappuarance of linguistic difterences due to 
immigrant origin, the disvalue or sterentype of linguistic patterns derived from regional and ethnic variation, and the insistence on English as a mark of linguistic and intellectual virtue. Telling Stories (Out of School) of Mother Tongue, God's Tongue, and the Queen's Tongue: An Ethnography in Canada gives attention to one such history. Told in Mennonite perspective and framed in Manitoba schools between 1890 and 1990, Telling Stories (Out of School) begins with tales of English-speaking Canadian insistence on and German-speaking Mennonite resistance to English-only language education policies in public and private schools serving a Mennonite speech community in southern Manitoba. The research problem links itself historically to a series of language education acts passed hy the Manitoba Legislature, adjudicated by the Manitoba Attomey General, the Canadian Supreme Court, and the British Privy Council, and enforced by the Manitoba Department of Education -- all between 1890 and 1920. These English-only policies, deemed an expedient response to the question of how to unify EnglishCanadians, French-Canadians, Aboriginals, and immigrants, abrogated the language education rights of all linguistic minorities. English prevailed in Manitoba schools until the 1960s. After the mid-1960s, though, the Canadian Parliament in concert with the Manitoba Legislature, the Manitoba Department of Education, and local public school districts re-affirmed Canada's English-French legacy as well as its multilingual, multicultural heritage with yet another series of language and language education acts -- the Canadian Official Languages Act of 1969, the Canadian Constitution Act of 1982, and the Canadian Multicultural Act of 1988. Today, the Canadian "Cultural Mosaic," or "Multiculturalism Within a Bilingual Framework, " dispels the "Melting Pot" myth borrowed from the United States at the turn of the century. And, the 1990 right to "language education choice" in Manitoha's system of public schools denies the 1890 rule of "One People, One Language, One School." To trace historical and recent developments in a Mennonite speech community associated with these policies, and subsequently with the contact of English, High German, and Low German "outside the classroom, " the ethnographer -- 
an irsider-outsider -- synthesizes the Hymes-type work in ethnographies of speaking and the Milroy-type work in language and social networks to examine the Ferguson-coined phenomenon of diglossia and the Fishman-extended relationship between socieral diglossia and individual bilingualism. Interviews with fifty-seven speakers, treated as a sequence of ethno-acts and ethno-events, are guided by the general question of sociolinguistic research -- who uses what language with whom, when, where, and why? Using Hymes' mnemonic code of SPEAKING leads to the description of a shared history and a shared way of speaking, as well as to insights into linguistic continuity, change, and compartmentalization. Telling Srories (Out of School) endlsi with tales of an ethnic revival in Mennonite schools and community today -- with new voices speaking Low German, High German, and English. While the present eihnography of a Mennonite speech community in Canada, framed in Manitoba schools between 1890 and 1990, should be regarded as impressionistic and preliminary, the fact remains -- language dominance does do something to the life of language in a community as does language education policy that atternpts to "start where the child is . . linguistically." 


\section{ACKNOWLEDGEMENTS}

For the travel and research grant that made this ethnography possible, I thank the Canadian Embassy, its Canadian Studies Graduate Student Fellowship Program, and Norman London, academic officer. For their briefings on Canadian social policy and Manitoba educational policy, I am indebted to the Manitoba Department of Education and Training, especially Ed Buller, deputy minister; Eliana Handford, coordinator of languages, multiculturalism, and ESL; and Abe Peters, German language consultant. For the opportunity to see and hear about "language education choice" in practice, I thank the board members and educators with the River East, Hanover, Garden Valley, and Rhineland school divisions, noteably Robert Cross, assistant superintendent of the River East School Division, and Gilbert Unger, superintendent of the Hanover School Division. For their assistance with the collection of data, I thank the many people in the Mennonite community, particularly Heidi Ens-Harms and Di Brandt, poets; Jacob Loewen, linguist; Peter Zacharias, historian; Lawrence Klippenstein, archivist with the Mennonite Heritage Centre; Kenneth Reddig, archivist with the Centre for MB Studies in Canada; Harry Loewen, chair of Mennonite Studies, and Al Reimer, professor emeritus of English, both at the University of Winnipeg.

For their scholarship and their mentorship, I remain indebted to the five exceptional people at Portland State University who served on my dissertation committee: Joan Strouse, committee chair and professor of education, who thoughtfully guided me and this interdisciplinary effort from its beginning and tirelessly read, listened to, and commented on stories; James Nattinger, head of the Department of Applied Linguistics, who caused me to

rethink everything I know about language and language learning; Jerry Lansdowne, professor of urban studies, who molded my thoughts about community science and community building; William Greenfield, professor of education, who encouraged an interdisciplinary approach to 
scholarship in education; and Robert Everhart, dean of the School of Education, who influenced me and this study with engaging discussions of ethnography. Finally, on the home front, I

thank Frank Swinney and Erik Swinney for cheering me on. 
TABLE OF CONTENTS

PAGE

ACKNOWLEDGEMENTS $\ldots \ldots \ldots \ldots \ldots \ldots \ldots \ldots \ldots \ldots \ldots \ldots \ldots \ldots \ldots$ ii

LIST OF FIGURES $\ldots \ldots \ldots \ldots \ldots \ldots \ldots \ldots \ldots \ldots \ldots \ldots$ viii

PROLOGUE TO TELLING STORIES (OUT OF SCHOOL) $\ldots \ldots \ldots \ldots \ldots \ldots \ldots$

\section{CHAPTER}

I MOTHER TONGUE! GOD'S TONGUE! ENTER THE QUEEN'S TONGUE! A TELLING STORY OF LANGUAGE IN ANGLO-AMERICAN

SCHOOLING .......................

"What! Learn English! My Children Shall Not!":

A Speech Act in a Mennonite Private School Around $1890 \ldots \ldots$. . . . . 1

"One People, One Language, One School System":

Speech Acts in the Manitoba Legislature Between 1890 and 1960 . . . . . . 3

An English-only Stump Speech

A French Appeal to the British-Canadian Tribunal

A Mennonite Appeal to the British-Canadian Tribunal

A Circumspect View of Events Between 1890 and 1960

"Multiculturalism Within a Bilingual Framework":

Speech Acts in Parliament and the Manitoba Legislature Between 1960 and

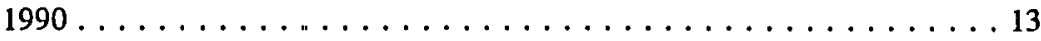

Trends in the Canadian Parliament

Directions in the Manitoba Legislature

Language Education "Choice" in Manitoba Public Schools

A Telling Story $c$ Language in Anglo-American Schooling $\ldots \ldots \ldots 18$

II TOWARD ETHNOGRAPHY AS "COMMUNITY SCIENCE": AN INTERDIISCIPLINARY MODEL OF A SPEECH COMMUNITY . . . 21

A Tradition of Ethnography $\ldots \ldots \ldots \ldots \ldots \ldots \ldots \ldots \ldots$

A Question of Mother Tongue and God's Tongue:

Ferguson's (1959) Speech Act on "Diglossia" . . . . . . . . . . . . 26 
Ferguson's Pioneering Research on Diglossia High-Low Language Criterion and Rubrics The Issues of Origin and Stability

A Question of Mother Tongue, God's Tongue, and the Queen's Tongue:

Fishman's (1967) Speech Act on Diglossia and Bilingualism . . . . . . . 35

Fishman's Pioneering Extension of Diglossia

An Interactive Model of Diglossia and Bilingualism

An Interactive Model of Biculturalism and Di-ethnia

The Issues of Maintenance, Shift, and Revival

Ethnography as "Community Science":

Hymes' (1961) Speech Act on "The Ethnography of Speaking" . . . . . . 50

Problems of "One Language" Attitudes, Policies, and Goals in Schools

The Ethnography of Speaking: An Interdisciplinary

Concept

The Ethnography of Speaking: Some Initial Heuristic Schema

The Ethmography of Speaking: Imperatives for Change

III ETHNOGRAPHY OF SPEAKING IN A MENNONITE COMMUNITY:

AN INSIDER-OUTSIDER FRAMEWORK $\ldots \ldots \ldots \ldots \ldots \ldots \ldots 61$

Starting From Language $\ldots \ldots \ldots \ldots \ldots \ldots \ldots \ldots$

A Century of Languge Education Debate

Pre-existing Models and Intuition

An Insider-Outsider Framework

Entering the Mennonite Speech Community:

Speech Events During the Summer of 1989

Assuming an Insider-Outsider Persona -- Months Before

Crossing the Forty-ninth Parallel -- The Day of 3 July

Touring the Historical Mennonite Reserves -- The Day of 3 July

Touring the Present-day Mennonite Speech Community -- The Week of 3 July

Interviewing Speakers in the Mennonite Speech Fields:

Speech Events in the Urban North End and the Rural Reserves . . . . . . 79

Asking the Grand Tour Question -- The Week of 3 July

Asking Insider-Outsider Questions -- The Weeks After 3 July

Assembling and Analyzing Languge and Social Data -- The Weeks

and Months After 3 July

Re-attaching "Back Home" -- Months Later

Re-Entering the Mennonite Speech Community: The Summer of $1990 \ldots 92$ 


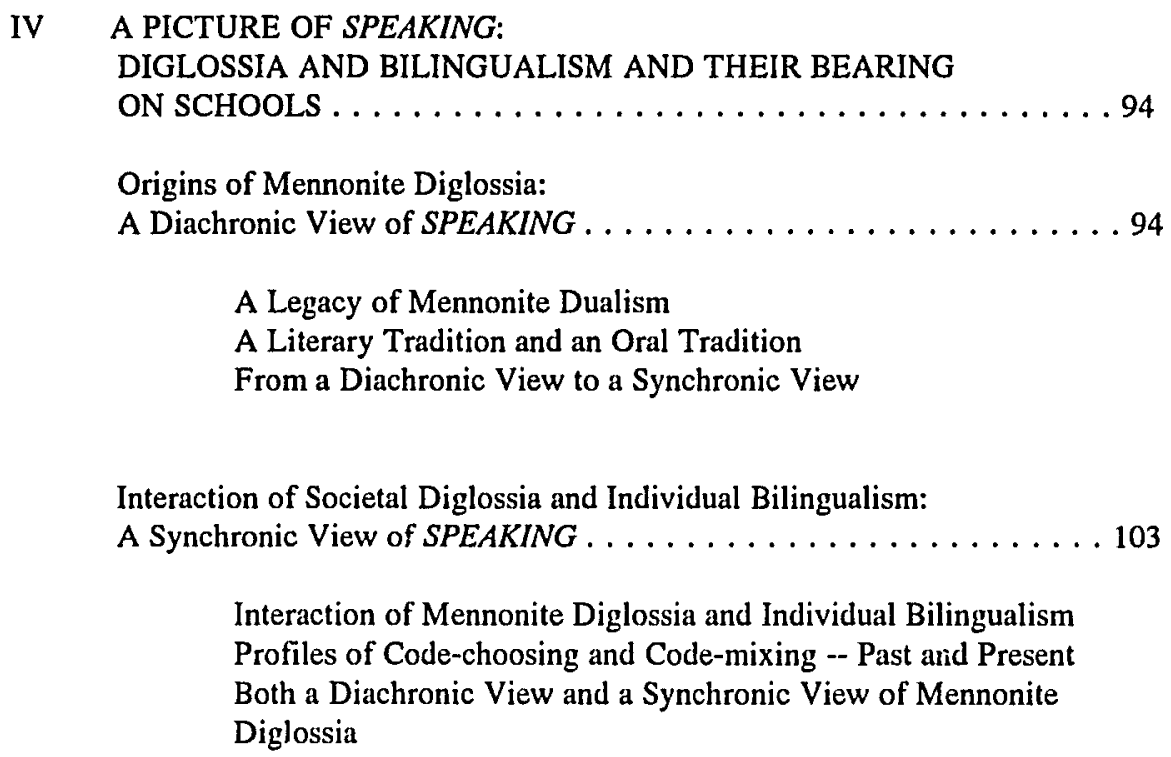

Origins of Mennonite Diglossia:

A Diachronic View of $S P E A K I N G \ldots \ldots \ldots \ldots \ldots$
A Legacy of Mennonite Dualism
A Literary Tradition and an Oral Tradition
From a Diachronic View to a Synchronic View

Interaction of Societal Diglossia and Individual Bilingualism:

A Synchronic View of SPEAKING . . . . . . . . . . . . . . . 103

Interaction of Mennonite Diglossia and Individual Bilingualism Profiles of Code-choosing and Code-mixing -- Past and Present Both a Diachronic View and a Synchronic View of Mennonite Diglossia

V COMING FULL CIRCLE:

AN ETHNIC REVIVAL IN SCHOOLS AND SCHOOLING. . . . . . . . 130

History Need Not Repeat Itself . . . . . . . . . . . . . . . . . . 130

Issues, Imperatives, and Questions . . . . . . . . . . . 131

U.S. Policy-makers, Educators, and Linguists Should Take a Look at Historical Problems of One People, One Language, One School Policies

U.S. Policy-makers, Educators, and Linguists Should Take a Look at Canada's Idea of Cultural Pluralism

U.S. Policy-makers, Educators, and Linguists Should Step Back Imaginatively and Ask "What If?"

EPILOGUE . 139

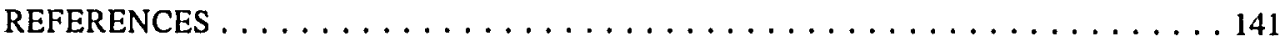

APPENDICES

A INSIDER-OUTSIDER INTERVIEW: GUIDELINE, SPEAKER, QUESTIONS, AND CODES . . . . . . . . . . . . . . . . 162

B LANGUAGE AND SOCIAL DATA . . . . . . . . . . 172

C DATA SUMMARY . . . . . . . . . . . . . . 174

D NETWORK INDEX SORT ................. 181 


\section{LIST OF FIGURES}

FIGURE $\quad$ PAGE

1. Language Education "Choice" in Manitoba ............. . 17

2. An Historical Problem in Anglo-American Schooling . . . . . . . . . 20

3. Ferguson's "High-Low" Criterion and Defining Languages . . . . . . . . 29

4. Ferguson's "Function" Criterion . . . . . . . . . . . . . 30

5. A Model of Ferguson's Diglossia ................ 36

6. Fishman's Types of Diglossia . . . . . . . . . . . . . . . 40

7. Fishman's Interactive Model of Diglossia and Bilingualism . . . . . . . 42

8. A Model of Fishman's Diglossia and Bilingualism . . . . . . . . . . 46

9. A Model of Hymes' Ethnography of Speaking . . . . . . . . . . . . . 59

10. Mennonite Reserves in Southern Manitoba . . . . . . . . . . . . 72

11. Mennonite East Reserve in Southern Manitoba . . . . . . . . . . . 73

12. Mennonite West Reserve in Southern Manitoba . . . . . . . . . . . . . 74

13. Kildonan on the North End of Winnipeg . . . . . . . . . . 75

14. Mennonite Communities Around the World . . . . . . . . . . . . 78

15. A Schematic of Milroy's Network . . . . . . . . . . . . . 84

16. Relations Between $S P E A K I N G$ and Questioning . . . . . . . . 85

17. Insider-Outsider Protocols $\ldots \ldots \ldots \ldots \ldots \ldots \ldots \ldots \ldots \ldots \ldots \ldots \ldots \ldots$

18. Anabaptist Movement in Europe ................... 98

19. Mennonite Settlement in Eastern Europe . . . . . . . . . . . . . . . . 99

20. Mennonite Settlement in North America . . . . . . . . . . . . . . 100

21. Profile of Diglossia and Bilingualism -- Past . . . . . . . . . 109 
22. Profile of Diglossia and Bilingualism - Present $\ldots \ldots \ldots \ldots \ldots \ldots 110$

23. Profile of Repertoires -- Past $\ldots \ldots \ldots \ldots \ldots \ldots \ldots \ldots \ldots \ldots 11$

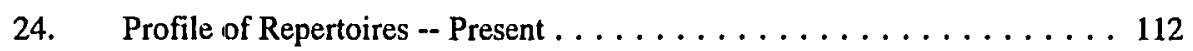

25. A Profile of a Kanadier Speech Network . . . . . . . . 113

26. A Profile of a Russlaender Speech Network ............ 114 


\section{PROLOGUE TO TELLING STORIES (OUT OF SCHOOL)}

Stories are central to Telling Stories (Out of School). For stories themselves (not to mention conversations, songs, jokes, prayers, rituals, hymns, tales, instructions, ceremonies, riddles, doctrines, and laws) -- all "speech acts and speech events" -- constitute "the very warp and woof" of ethnic life (Fishman, 1985b, p. xi). But here, in Telling Stories (Out of School): An Ethmography in Canada, stories reveal links between language and ethnicity in a Mennonite speech community in southern Manitoba. Indeed, vignettes of Mother tongue (Plautdietsch or vernacular Low German) and God's tongue (Hochdeutsche or classical High German) coming in contact with the Queen's tongue (Canadian English) between 1890 and 1990, reveal language to be "a part . . . an index ... and a symbol" (Fishman, 1985b, pp. 501-505) of Mennonite ethnicity. For Mennonite storytellers themselves describe Plautdietsch as the "down-to-earth" language of home and village "capable of expressing the ... 'soul'" (Klassen, 1989, p. 8) of the Mennonite experience (Reimer, 1983, p. 11). They characterize Hochdeutsche as the "otherworldly" (Loewen, 1980, p. 85) language of the Mennonite meetinghouse and schoolhouse that separates the prosaic here and now from the utopic hereafter and maintains "the barrier against .

.. national languages" (Loewen, 1986, p. 85). They refer to English as the "worldly" (Loewen, 1980, p. 6) language of English-Canadian schools after 1890. And, the fact that these Mennonite storytellers choose both English and German to tell stories of their experiences in German-only schools in Mennonite private schools around 1890, in English-only "national" schools after 1920 (Bergen, 1950; Ens, 1978, 1980; Epp, 1974, 1982; Epp-Thiessen, 1982; Klassen, 1989; Loewen, 1965, 1968; Loewen, 1982; Peters, 1985; Zacharias, 1976; Loewen \& Reimer, 1985; Reimer, Reimer, - Thiessen, 1983), and in English-German bilingual public schools now, (no snall detail), shows education to be a complex ethno-cultural arena -- a "field" 
(Lewin, 1939; Bales, 1950, 1979) of interaction and change (Fishman, 1972, 1985, 1989;

Hymes, 1967, 1974, 1980, 1986).

To follow the intricate processes of interaction and change is the ultimate aim of this ethnography in Canada (the thesis I proposed in committee in 1989, and defended in 1991). To have asked Mennonite storytellers in "the field," during the summer of 1989 -- Who uses what language where, when, and why? (Fishman, 1972, p. 46) -- reveals a telling story of language continuity, language conflict, and language compartmentalization in a Mennonite speech community. To have reconsidered the question in the field again, during the summer of 1990 -Is it possible that the narrower issues "change and continuity" in "sidestream" ethnicity and language reflect the broader issues of "shift and constancy" in "mainstream" ethnoculture? (Fishman, 1985b, pp. 502-517) -- yields a qualitative yes when I compare evidence of a Mennonite ethnic revival with that of the "widespread North American . . . 'ethnic revival' of the mid-60s and mid-70s" (Fishman, 1985b, p. xii). It seems possible that the narrower issues sidestream issues of Mennonite language and ethnicity may indeed reflect broader mainstream issues of Canadian "multiculturalism within a bilingual framework" (Wardhaugh, 1983). The yes, however, is tentative and begs further study.

Turning now to the organization of Telling Stories (Out of School), "speech acts" and "speech events" constitute beginning, middle, and end of the ethnography. In early chapters, stories lend both an historical and a present-day context to the ethnography of speaking English and German in a Mennonite community in southem Manitoba. In Chapter I, for example, German-speaking Mennonite storytellers themselves describe the historical "problem" of German-only Mennonite ethnicity in local schools while English-speaking Canadian storytellers offer the historical "solution" of English-only attitudes, policies, and goals in Anglo-American education, all framed in Manitoba schools between 1890 and 1990 (Clark, 1968; Cook, 1966; Epp, 1974, 1982; Ewart, 1894; Peters, 1985; Wardhaugh, 1983). Then policy-makers, 
linguists, and educators talk about the legacy of English-French dualism in Canada; the trends toward bilingualism and multiculturalism in goverment, schools, and communications since the 1960s (Beer \& Jacob, 1985; Burnaby, 1987; Cummins, 1984, 1988, Ducharme, 1984; Edwards, 1984; Elliott, 1983; Foucher, 1985; Wardhaugh, 1983, 1986, 1987); and the policies and practices in bilingual education in Manitoba public schools since the 1970s (Dyck, 1986; Manitoba Education, 1983a, 1983b, 1988, 1989a, 1989b, 1990; Plett, 1986; Manitoba Parents, 1985, 1988; River East, 1989; Malyzynsky, 1989). In Chapter II, international sociolinguists advance interactive models of ethmolinguistic dualism -- diglossia (Ferguson, 1959), diglossia with and without bilingualism (Fishman, 1967), and di-ethnia (Fishman, 1980) -- as a way of explaining issues of literacy and language development in multilingual, multicultural societies, and point to the tradition of ethnography as a way of knowing and following the "holistic and nonquantitative 'poetic' perspectives" (Fishman, 1985b, p. 473) of language use in the educational experience (Hymes, 1961, 1974, 1980). In chapters $I I I$ and $I V$, I myself tell stories of entering and re-entering the Mennonite speech community to undertake the ethnography during the summers of 1989 and 1990; of assuming an insider-outsider persona (Milroy, 1986); and of enmeshing myself in speech networks of within the Mennonite speech community. There, I find evidence of an ethmic revival that is recreated and reinterpreted by some speakers in Plautdietsch, by others in Hochdeutsche, and by still others in English given myriad possibilities of interaction among "persons ... places ... topics ... role relationships" in community and school (Fishman, 1985b, p. 503). The markers of this particular ethnic revival include increases in mother-tongue claims (Klassen, 1989, pp. 3-18), increases in mother-tongue writings (Loewen \& Reimer, 1985, pp. 279-286) and mother-tongue schools, and finally, calls for research in ethnic studies at universities (Loewen, 1980), at heritage centers (Loewen, 1986), and in political arenas (Manitoba Minister of Culture, 1990; Manitoba Minister of Education \& Training, 1990). 
Near the end of Telling Stories (Out of School), in Chapter V, I shift my point-of-view from narrower issues of language continuity and change in the sidestream to broader issues of language maintenance and shift in the mainstream. For inside the local speech community, Mennonites who claim to use both Low German and High German say that one-language attitudes expressed in Manitoba public school policies and Canadian social policy in the first half of the twentieth century contributed to a gradual shift from German to English (Klassen, 1989, p. 7). Now, in the second half of the century, they add, Canada's pluralistic language policies and Manitoba's bilingual educational policies (Journal, 1989, pp. 44; Manitoba 1983c) "have helped to create an atmosphere in which it is not only acceptable, but even desirable to express one's ethnicity" (Klassen, 1989, p. 6). Beyond the local Mennonite speech community, Manitoba policy-makers and educators who oversee language education policy and practice in Manitoba public schools say local communities have taken advantage of federal and provinciai legislation enabling them to exercise "language education choice" in local schools (Ducharme, 1988; Manitoba Education, 1989a). Francais and French immersion programs piloted during the 1970s, and English-German, English-Hebrew, and English-Ukrainian bilingual programs piloted during the 1980s, have gained community acceptance (Manitoba Education, 1983a, 1983b, 1988, 1989a, 1989b, 1989c, 1990). Early assessments of those bilingual programs indicate that students master content in both languages, achieve proficiency in English equal to students in English-only programs (Manitoba Education, 1988, p. 12), and "learn tolerance and gain self-confidence in their own abilities" (Manitoba Education, 1983c p. 48). As one policymaker says, "bilingual education fosters mutual respect in all shades of good" (Journal, 1989, p. 54).

Given this particular account of history, perhaps policy-makers, linguists, and educators in the United States, like those in Canada, should give attention to their own language histories. Perhaps they too should step back imaginatively and ask "What if . . Why . . How 
did it start?" (Hymes, 1980, p. 71). Given this prologue to Telling Stories (Out of School), I turn now to one particular story of language that started in a Mennonite Private School around 1890, and the words (in German): "What! Learn English! My children shall not!" (Epp, | 1974). 


\section{CHAPTER I}

MOTHER TONGUE! GOD'S TONGUE! ENTER THE QUEEN'S TONGUE! A TELLING STORY OF LANGUAGE IN ANGLO-AMERICAN SCHOOLING

Reflecting on the last one-hundred years of language attitudes, policies, and goals in Anglo-American schooling, a linguist and dean of a school of education called for an imaginative solution to an historical problem ...

Histories... give little attention to it. A broad picture is clear enough: wipe out the [Native] languages, erase linguistic differences due to immigrant origin, disvalue or stereotype dialect, insist on a single standard as a badge of intellectual and personal virtue. Lirtle seems to be known about the formation of these views in schools of education, their implementation in schools and school districts, the tensions, and interactions, and adjustments in specific regions, where specific configurations of linguistic difference and verbal repertoire prevailed. One senses a pervasive difference in atritude today berween groups differently situated in the class structure, a pattern of difference perhaps between the Eastern seaboard and the West, but without adequate documentation.

Perhaps we need to step back, imaginatively, in a way analogous to "zero-budgeting." What if. . . Why . . . How did it start? (p. 71).

Del Hymes (1980)

\section{"WHAT! LEARN ENGLISH! MY CHILDREN SHALL NOT!" A SPEECH ACT IN A MENNONITE PRIVATE SCHOOL AROUND 1890}

Mother tongue (vernacular German) and God's tongue (classical German), together with a right to teach Deutsche und Religion (catechism) in Mennonite private schools, stirred Mennonites to emigrate from Russia to Canada, during the 1870s and 1880s (Dyck, 1980, p. 
201). What awaited them on the Manitoba prairies, in the 1890 s, was the Queen's tongue (Canadian English), or in the words of a Mennonite patriarch, "a rationale for [Canadian] public schools . . one king, one God, one navy, one all-British empire" (Epp, 1974, p. 333).

These Mennonites sensed, rightly so, that English schools threatened the survival of their school and their community, their way of life. An anonymous observer, likely a school inspector fluent in English and German, participated in a gathering of villagers at a Mennonite private school, around 1890 (Epp, 1974). His record of a speech act (talk, in this case, in vernacular German, transcribed in classical German, and translated into Canadian English) foreshadowed an event that loomed ahead in Canada, the passage of legislation compelling German-speaking Mennonites to close their Mennonite private schools and send their children to "national" English schools (Peters, 1985):

An Older Neighbor: We do not wish to have an inspector. Our schools are good enough.

A Younger Neighbor: I believe it would be well if we could have some English in our schools.

Several Voices: What! English?

Other Younger Neighbors: Why not? We should know how to read and write English. That is necessary. Who now can really decipher the government letter that has been sent to us?

An Older Person: That is entirely unnecessary. Our schools are private schools and the government has nothing to say to them.

$A$ Voice from the Rear: No, he must not be allowed to do that. We must treat the government with respect.

A Neighbor: Have they not promised religious freedom to us?

A Voice from the Rear: And in Canada one must know how to speak Canadian, that is English.

An Older Person: That shows the new spirit. Beware of such suggestions. That is the beginning of the end. For twenty years we have not leamed English and were happy without it. But today, many are getting along too well. The young men know better than their elders the things that ought to be done. 
Another Older Person: The Bible has been written in German, why then should we have to learn English. My children at least shall not do so.

A Third Elderly Person: Neither shall mine (Epp, 1974, pp. 342-343; italicized language mine).

Word of "an inspector . . English . . . a government letter . . . religious freedom . . . the new spirit . . the German Bible . . . my children" spread from the Mennonite German private school to Mennonite villages across the Manitoba prairies. Talk turned into an organized movement to avoid "national" schools, generally; to resist English and the Union Jack, specifically; to preserve Deutsche und Religion, ultimately (Bergen, 1959; Ens, 1974, 1980; Epp, 1974, 1982; Francis, 1953; Peters, 1985; Redekop, 1989).

In a sequence of acts and events including the Manitoba Legislature's passage of the Public Schools Act in 1890, the British Privy Council's denial of the Mennonites' appeal to reopen Mennonite private schools in 1920, and the Canadian Parliament's restoration of minority language rights in 1969, German-speaking Mennonites found themselves embroiled in a bitter controversy over linguistic dualism in Manitoba schools. The chain of events marked the official entry of the Queen's tongue in the Mennonite speech community (Clark, 1968; Cook, 1966; Epp, 1974, 1982; Ewert, 1894; Peters, 1985).

\section{"ONE PEOPLE, ONE LANGUAGE, ONE SCHOOL SYSTEM": SPEECH ACTS IN THE MANITOBA LEGISLATURE BETWEEN 1890 AND 1960}

Claims and counterclaims heard from the pulpit, the press, and the bench, marked official English "a problem" for German-speaking Mennonites in Manitoba (not to mention all linguistic minorities in Canada). The problem first surfaced in 1889, when an English-speaking attorney and spokesperson from the so-called "Equal Rights Association" in Ontario talked to Manitobans about "One People, One Language, One School System" (Clark, 1968, pp. 2-5). One year later, the "infamous" Ontario attorney and the Manitoba Attorney General led the 
English-Canadians in the Manitoba Legislature to ratify the Manitoba Public Schools Act of 1890 (Wardhaugh, 1983, p. 119). In "the most significant move . . . in Western Canada," the English majority abrogated language and school rights of all linguistic minorities and gave Manitoba a system of secular English schools "modelled on that of Ontario . . . and on the nonsectarian schools of the mid-western American states to the south" (Wardhaugh, 1983, pp. 119120). So the Manitoba school language question became a searing political issue that not only separated the Conservatives from the Liberals but also dissevered English-Protestants, FrenchCatholics, and German-Mennonites. Each linguistic group took a position on the Manitoba school language question.

An English-only Stump Speech

An English-speaking preacher, a known crony of the Manitoba Attorney General and the infamous Ontario attorney (Clark, 1968), spoke of the "polyglot" from the pulpit and before the press in the 1890s. In a sermon entitled "One Canadian People" (Bryce, 1889) and, later, in an article entitled "The Manitoba School Question" (Bryce, 1893), he offered a rationale for English-only in Manitoba's public schools. He characterized a "unique" problem facing Manitoba: a province made up of ten-thousand Icelandic, Scottish, Ukrainian, Polish, Hungarian, and Finnish immigrants; twelve-thousand French-speaking Metis and Quebecers; and "fifteen thousand German-speaking Mennonites . . . more ignorant to-day as a people than when they came from Russia eighteen years ago" (Bryce, 1893, p. 64). Tossing out terms like "equal rights for all ... special privileges for none" (Bryce \& Ewert, 1889, p. 39), the preacher proposed an English-only "melting pot" based on principles applied in the American states to the south. There, he declaimed, English-only public schools anglicized French speakers in Louisiana; German speakers in Kansas, Illinois, Minnesota, and Nebraska; and Spanish speakers in Texas. If such a model worked to unite and homogenize an American people, then such a model would surely "rear up a homogeneous Canadian people," he concluded. 
Amid persuasive protests from Manitoba's linguistic minorities, the Manitoba

Legislature passed the 1890 Public Schools Act. In defense of the Legislature's action, the

Canadian Magazine published what Preacher Bryce, an English-speaking Presbyterian, called

"The Manitoba School Question" (Bryce, 1893), or what Preacher Dyck, a German-speaking

Mennonite, called "a rationale for [Canadian] public schools . . . one king, one God, one navy, one all-British empire" (Epp, 1974):

The problem facing Manitoba was unique. The province was made up of people of many nations. Its speech is polyglot, with the majority Englishspeaking.

What could patriotic Manitobans do? They were faced with the prospect of whole masses of the population growing up illiterate. The Mennonites, who came from Russia, are more ignorant to-day as a people than when they came from Russia eighteen years ago. Yes, British Manitoba has been a better foster-mother of ignorance than . . . Russia had been.

The only hope for the province was to fall back on the essential rights of the province, and provide one public school for every locality, and have a vigorous effort made to rear up a homogeneous Canadian people . . . . the first steps have been taken, and in the mind of most . . . the battle has been won.

There was no abuse of Catholics, or Mennonites, or foreigners. There has not been the slightest animosity manifested. Violence was unknown in the campaign, or at the polls. There was simply the conviction that public schools are a great necessity . . . that they are the only fair system yet devised for meeting prevailing ignorance; and that in order to make us a united people, a patriotic love of our province demands this expedient.

Our French-Canadian and Mennonite fellow-countrymen are coming to see this (Bryce, 1893, in Clark, 1968, pp. 63-64).

But, neither the Russian-Mennonites nor the French-Canadians had come "to see this." Between the 1890s and the 1920s, both linguistic minorities appealed their cases for language education rights to British-Canadian judicial system, not without "abuse . . animosity . . . violence."

\section{A French Appeal to the British-Canadian Tribunal}

Outraged by insults about illiteracy, Manitoba's linguistic minorities appealed their language education cause to the British-Canadian tribunal for intervention. The first appeal, one 
led by the French-speaking minority in the case of Brophy and others v. Manitoba Attorney General (1894), and supported by German-speaking Mennonites, challenged the authority of the Manitoba Legislature to mandate "English-only" schools on the grounds that the 1890 Public Schools Act violated the existing precedent for language education rights found in a careful reading of the articles of the Canadian Confederation. The Brophy case ended in 1897, with the Laurier-Greenway Compromise, an interim bilingual education compromise in Manitoba schools (Ducharme, 1988; Foucher, 1985).

Brophy and others v. Manitoba Attorney General (1894). To protest the so-called problem of French-Catholic schools, the linguistic minority took its language education cause to the Manitoba Courts. In Brophy and others v. Manitoba Attorney General (1894), the French minority argued that the 1890 Manitobal Public Schools Act violated the existing precedent for minority language rights found in a careful reading of Article 93 of the historic British North American Act of 1867, "the centrepiece of the Canadian Constitution until very recently" (Mallea, 1989):

The 1867 British North America Act. Nothing in any such Law shall prejudicially affect any Right of Privilege with respect to Denominational Schools which any Call of Persons have by Law in the Province at the Union (Clark, 1968, p. 102, emphasis mine).

and of Article 22 of the historic Manitoba Act of 1870 (Foucher, 1985, p. 190):

The 1870 Manitoba Act. Nothing in any such Law shall prejudicially affect any right of privilege with respect to Denominational Schools which any class of persons have by Law or practice in the Province at the Union (Clark, 1968, p. 102, emphasis mine).

The Brophy case moved from the Manitoba Court of Appeals in Winnipeg, to the Canadian Supreme Court in Ottawa. There, the Minister of Justice heard the case and referred it to the Judicial Committee of the Privy Council in London. In 1895, the Judicial Committee of the Privy Council held for Brophy and the minority but ruled that the jurisdiction for such questions of language education lay with the Province of Manitoba (Clark, 1968, pp. 118-177; 
Foucher, 1985, pp. 189-210; Mallea, 1989, pp. 57-60). The Judicial Committee returned the case to the Canadian Supreme Court where the Chief Justice addressed the constitutional issue of minority language rights:

The rights of the minority in this instance arise from a compact entered into between the people of Canada and those of the Red River, a compact ratified and made binding by the Parliament of both peoples and the Imperial Parliament as well ... The minority in defense of their rights have complied with every form of the law, have carried their case through every court of jurisdiction in the land to the foot of the Throne itself, have had their claims favorably decided upon by the highest court in the realm . . . Can any claim of expediency without the exercise of downright tyranny override the justice of the minority's demands? (Kribs, 1895, in Clark, 1968, pp. 177-181).

Minority Language Education Rights Restored in 1897. The issue did not die in closed judicial chambers. In 1896, the newly-elected Canadian Prime Minister found it politically expedient to listen to the voices of the linguistic minority. He promptly negotiated a compromise with the Manitoba Premier, the Laurier-Greenway Compromise of 1897, a middle course "to provide language rights for non-English-speaking children in the public schools and to permit religious instruction each day" (Durnford, 1978, pp. 334-335). From 1897, the year the Manitoba Legislature approved the compromise for bilingual education, until shortly after the turn of the century, communities of German-speaking Mennonites and French-speaking Catholics as well as other linguistic minorities took advantage of Manitoba's bilingual schools (Skelton, 1921, pp. 211-214, in Clark, 1968). But soon, talk of British patriotism and Canadian nationalism together with rumors of war with Germany turned liberal notions of bilingual education to conservative moves toward English-only schools. In the years surrounding Britain's 1913 declaration of war on Germany, the English majority in Manitoba recoiled to pass yet other school legislation designed to assimilate linguistic minorities.

\section{A Mennonite Appeal to the British-Canadian Tribunal}

Solemnly Mennonite passivists, who in 1890, uttered "What! Learn English? My children shall not ..., " turned into Mennonite activists resisting the Union Jack and the 
Queen's tongue in "national" schools after 1900. The Mennonite appeal for German language education rights in Mennonite schools, led by seven Mennonite congregations in southern Manitoba, in the case Manitoba Attorney General v Hildebrand and Doerksen (1919), tested the legality of English-only schools on the premise that the 1890 Public Schools Act breached the 1873 Canadian Priviligium, also referred to as the 1873 Orders-in-Council. The Hildebrand case ended in 1920, with the denial of German language rights in Manitoba schools, and a halt to all "flirtation with multiculturalism and multilingualism" (Wardhaugh, 1983, p. 121) in Manitoba until federal legislation in the 1960s revoked English-only language education acts. Events unfolded in this way.

Mennonite Resistance to "National" English Schools. Two events in the Manitoba Legislature between 1900 and 1920, passage of the flag-raising legislation of 1907, and passage of the Compulsory School Attendance Act of 1916, put an end to possibilities for GermanEnglish bilingual schools granted by the Laurier-Greenway Compromise. These acts essentially foreclosed on all remaining legal choices for German Mennonite private schools. The Mennonite resistance heightened after 1907, when the newly elected Manitoba Premier decreed that the "Union Jack, a symbol of the British Empire, be . . . raised in public schools daily" (Epp, 1974, p. 345). Resistance spread beyond the "Mennonite Reserves" in Manitoba, to reserves in Ontario and Saskatchewan, where the legislatures passed similar school laws promoting flag-raisings in "national" English schools. Protestors likened flag-raising ceremonies in national English schools to those in schools in Britain, the United States, not to mention Germany itself and called such acts a sign of rising militarism in national schools. Speaking before Parliament, on behalf of a German-speaking Mennonite delegation, an Englishspeaking Canadian law-maker explained that to these German-speaking passivists, flags and flagraisings in national English schools represented a nation preparing for war:

[We] regret the steps taken to inculcate the spirit of militarism in the minds of the rising generation and . . . we hereby express ourselves in favor of 
inculcating the principles of peace and good will to all men in the minds of our children, using every means to spread the means of peace (Epp, 1974, pp. 346347).

But public opinion tumed against Germany, against pacifism, against the Germanspeaking Mennonite passivists from Russia. Departments of education in Manitoba, Ontario, and Saskatchewan sent school inspectors into German-speaking communities with a "national" goal: to enforce flag-raising and English-speaking policies in public schools and to prosecute those in Mennonite districts who avoided or resisted English schools. In more than one situation, German-speaking congregations on the Mennonite Reserves in Manitoba, Ontario, and Saskatchewan found themselves making choices: at first, choosing between incentives for sending their children to "national" English schools, on one hand, and options for bilingual public schools or German private schools, on the other hand; later, choosing between being taxed, fined, or jailed by provincial authorities for speech acts in German, on one hand, or excommunicated by the congregation for speech acts in English, on the other hand. One desperate Mennonite appealed his predicament to the Minister of Education in a letter dated 1908:

Having the future of my children in view I took the necessary steps to join a more progressive branch of the Mennonite church. As soon as the leaders of the Old Colony [congregation] got notice of my steps they excommunicated me and forbade all the members to have any more dealing with me. The consequence was that I had to give up my home, my business, and everything for the sake of giving my children a better education and this in a land of the free. Now ... don't you think that existing conditions are an insult to our liberal constitution (Saskatchewan Archives Board, 1908, in Epp, 1974, pp. 353).

A swift retort came, not from the Minister of Education, but from the Premier:

Inform the Mennonite heads that unless they leave free those of their people who wish to use the public school we will compel the formation of Public School Districts where ever there are enough children of school age and will force the payment of taxes; and . . . inform them also that we will deprive them of the legal right to solemnize marriages (Saskatchewan Archives Board, 1908, in Ens, 1980, pp. 75-76). 
One member of the press blamed the government for "the loss of [French and German] schools 'to the national system'." An editor, following the Mennonite resistance on behalf of the Manitoba Free Press in 1910, warned Conservative legislators that "undue pressure" brought upon the Mennonites could lead to dislocation of these people and destruction of their villages and schools:

It is asserted quite positively that the conservative [Mennonite] people, are to this day so tenacious of their principles that if any attempt should be made on the part of the government to force public schools upon them or even to force them to teach English in their private schools -- not that they have any conscientious scruples against learning English, but because they resent all outside, that is government, interference -- they would leave the country in spite of the large material interests which they have there (Manitoba Free Press, 1910, in Epp, 1974, p. 348).

Eventually one third of the Mennonite population in Manitoba protested by enigrating to Mexico and Paraguay, but not until after the situation worsened.

Another newly-elected Manitoba Premier, determined to leave his mark on Manitoba education, led the Manitoba Legislature to pass the Compulsory School Attendance Act of 1916. The law not only compelled Mennonites to send their children to "national" schools. It also put an end to German-English bilingual schools granted by the Laurier-Greenway Compromise and forced closure of all German Mennonite private schools in Manitoba (Peters, 1985, p. 32). The Manitoba Minister of Education defended action taken by the Manitoba Legis|ature:

The immigrant children are the raw material of Canadian citizenship \#. . The sooner we understand this the quicker they will assimilate themselves to our conditions and the admixture we all desire will take place. We shall build up a Canadian nationality under the British flag, carrying on British justice, freedom, and democracy ...

In the past we have not been careful of whom we admitted, but have laken all classes from Germany, Russia, Italy, Austria, and given them the privileges of citizenship ... to those who come determined to be 100 percent Canadian . . . we will bid welcome, but if they come determined to stay German, to stay Ruthenian, we want them turned back (Thornton, 1916, in Peters, 1985, p.' 32). 
Manitoba Attorney General v Hildebrand and Doerksen (1919). Repeatedly, between 1916 and 1920, Mennonite patriarches, suited in black and governed by rules of Deutsche und Religion, appealed to the British-Canadian tribunal, robed in black and governed by policies on English and the Union Jack. Led by a Mennonite Bishop, the Mennonite Emergency Delegation on Education entered the case of Manitoba Attorney General v Hildebrand and Doerksen (1919), a defense of Deutsche und Religion in Mennonite private schools based upon the promises of the 1873 Canadian Orders-in-Council and the 1873 Canadian Priviligium. In closed chambers, the German-speaking Mennonite minority reminded the English-speaking majority that the Ordersin-Council granted the Mennonites, along with the Quakers, pacifist status and that the Canadian Priviligium guaranteed Mennonites "exemption from military service . . . free land grants on the condition of settlement ... the privilege of affirming instead of making affidavits ... warrants from Hamburg to Fort Garry" and, above all, "privilege of religious freedom extended to the education of children in schools" (Friesen, 1985, pp. 16-17).

The Hildebrand case moved from Manitoba's Court of Appeals, through Canada's Supreme Court, to Britain's Privy Council in London, and climaxed in June of 1920, when the Judicial Committee of the Privy Council denied the Mennonites their German language education rights. In a narrow interpretation of the British North America Act of 1867 and the Manitoba Act of 1870, the justices found Article Ten of the Canadian Priviligium, the legal rationale for the defense of Mennonite private schools, to be null and void in matters of language education in the Province of Manitoba. Neither the 23 July 1973 version of the Priviligium, stating:

The Canadian Priviligium of 23 July 1874. That the Mennonites will have the fullest privilege of exercising their religious principles is by law afforded [emphasis added by Epp, 1982] the Mennonites, without any kind of molestation or restriction whatever (Epp, 1982, p. 106)

nor the revised 13 August 1873 version filed as Canadian Orders-in-Council, stating: 
The Order-in-Council of 13 August 1873. That the Mennonites will have the fullest privileges of exercising their religious principles, and educating their children in schools, as provided by law [emphasis added by Epp, 1982], without any kind of molestation or restriction whatever (Epp, 1982, p. 106)

held in the case of Manitoba Attorney General v Hildebrand and Doerksen (1919) (Epp, 1974,

1982; Mallea, 1989; Peters, 1985). In the context of the Mennonite community, the 1890

Manitoba Public Schools Act together with the 1916 Manitoba Compulsory School Attendance

Act, essentially denied the Mennonites the right to teach Deutsche und religion in the Mennonite

private schools. Increasingly after the 1920s, Mennonite mother tongue (vernacular German)

and God's tongue (classical German) fell victim to the confounded issues of Canada's national

policy to promote English and the Union Jack.

\section{A Circumspect View of Events Between 1890 and 1960}

A Canadian linguist provided a "century-spanning appraisal of language and ethnicity in Canada" and looked circumspectively at the Manitoba Public Schools Act of 1890 . He characterized the school language act and its impact on linguistic minorities as "the most significant move ... in western Canada" (Wardhaugh, 1983, p. 119). Commenting on the relative status of English, French, and immigrant languages before and after the 1890 Act, he remarked (Wardhaugh, 1983, pp. 119-121):

When Manitoba . . . was founded in 1870, there was no threat to the French [minority nor to the Mennonite minority] in the new province: their linguistic and ... [denominational] rights were apparently guaranteed. But within a very few years much of the tolerance for the French language [and immigrant languages] . . that had existed at the time of Confederation and the passing of the Manitoba Act of 1870 had been replaced by a desire to make the West conform to "English" traditions. The provisions of the British North America Act were given their most limited interpretation: there would be conformity to its letter rather than it spirit. Provincial legislation which changed language laws went unchallenged by the federal government, secular English schools became the model almost everywhere (Wardhaugh, 1983, p. 119).

The most significant move against the French [and Mennonites] in western Canada was the decision of the Manitoba Legislature in 1890 to remove state support from the ... [denominational school system] of the province ... . That those privileges had been granted under the Manitoba Act of 1870 [and 
the Canadian Priviligium of 1873] was of no consequence. Since they pertained to education, a provincial responsibility, they could be removed, or so the argument went (Wardhaugh, 1983, pp. 119-120).

Essentially, the English majority settled the issue of English-French dualism and

English-German dualism by dismantling the system of denominational schools guaranteed by the

Canadian Confederation.

The mid years of the 1890s saw the . . Catholics [and Mennonites] in Manitoba take their case to the Privy Council in London where they ultimately gained support for their claim that their rights had been infringed and that their grievance was legitimate .... the outcome gained only a compromise solution, the Laurier-Greenway compromise of 1896 , enacted into Manitoba law the following year . . . . the compromise . . . left open certain possibilities for a variety of bilingual schools, possibilities that many groups in addition to the French [including the Mennonites] took advantage of at the turn of the century. However, the outbreak of World War I brought an end to this flirtation with multiculturalism and multilingualism. Such a policy was felt not to be in the best interests of a country committed, outside of Quebec at least, to a defense of King and Empire. Bilingual education was suppressed and the Manitoba French [and Mennonites] had to wait until 1970 for the restoration of their right to have their children educated in French [German] (Wardhaugh, 1983, pp. 120-121).

Clearly, the Manitoba Public Schools Act of 1890 was a "most significant move." The "move" virtually denied all minorities language education rights, and it superposed English on German-speaking Mennonites in Manitoba and Saskatchewan, indeed on all linguistic minorities in Western Canada. Increasingly after the 1890 s and until the 1960 s, the minority language education rights remained suppressed in Manitoba while the notion of a nationalizing AngloAmerican "melting pot" spread across Canada (Clark, 1968; Wardhaugh, 1983, 1987).

\section{"MULTICULTURALISM WITHIN A BILINGUAL FRAMEWORK": SPEECH ACTS IN PARLIAMENT AND THE MANITOBA LEGISLATURE BETWEEN 1960 AND 1990}

Canada moved boldly in the 1960 s to dispel the "melting-pot" myth borrowed in the

1890s from the American states to the south. The then new Prime Minister from Quebec, fluent in English and French, began to articulate a new Canadian agenda for the twenty-first century, an agenda of unity through diversity. He called for an end to "One People, One Language" 
nationalism, the hallmark of North American and Western European ethnoculture in the

nineteenth and twentieth centuries, and called it a "rustic and clumsy" tool to be discarded:

In the advanced societies, where the interplay of social forces can be regulated by law, where the centres of political power can be made responsible $\mid$ to the people, where the economic victories are a function of education and automation, where cultural differentiation is submitted to ruthless competition, and where the road to progress lies in the direction of international integration, nationalism will have to be discarded as a rustic and clumsy tool (Trudeau, 1968, p. 202).

Instead, he spoke of a new Canadian federalism, a new ethos or a "Cultural Mosaic" to inform the beliefs, customs, and practices of a pluralistic society:

The die is cast in Canada: there are two main ethnic and linguistic groups: each is too strong and too deeply rooted in the past, too firmly bound to a mother-culture, to be able to engulf the other. But if the two will collaborate at the hub of a truly pluralistic state, Canada could become the envied seat of a form of federalism that belongs to tomorrow's world . . . . Canada would offer an example to all those new Asian and African states . . . who must discover how to govern their polyethnic populations with proper regard for justice and liberty . . . Canadian federalism is an experiment of major proportions; it could become a brilliant prototype for the moulding of tomorrow's civilization (Trudeau, 1968, pp. 178-179).

Following the Prime Minister's lead, the Canadian Parliament took steps to re-affirm the legacy of English-Canadian, French-Canadians, immigrants, and Native peoples inherited at the Battle on the Plains of Abraham. The Prime Minister, a provocative spokesperson for the French minority and elected leader of the English majority, transformed Canada's legacy of linguistic dualism into a trend toward cultural pluralism. Parliament and the Prime Minister coined it "Multiculturalism Within a Bilingual Framework." Thus the historical problem of unity through Anglo-American conformity gave way imaginatively to a futuristic trend toward Canadian unity through ethno-cultural plurality.

\section{Trends in the Canadian Parliament}

Canada launched its experiment in "multiculturalism within a bilingual framework" in 1963, when Parliament appointed a Royal Commission on Bilingualism and Biculturalism "to 
look into the relationship between the English and French in Canada and make recommendations for changes" (Wardhaugh, 1987, p. 223). Acting on the reports of the Royal Commission and on the successes of the Civil Rights Movement in the United States as well (Wardhaugh, 1983, pp. 39-46), the Canadian Parliament passed legislation proclaiming a dominantly Englishspeaking country to be an "officially bilingual" nation and an "officially multicultural" society (Wardhaugh, 1983, pp. 198-218). In effect, the Official Languages Act of 1969 restored French language rights outside Quebec and declared English and French to be the official languages throughout Canada, i.e. in government, communications, and education; the Constitution Act of 1982 together with the Charter of Rights and Freedoms, enshrined English and French in the Constitution and guaranteed language education rights to all of Canada's linguistic minorities, i.e. French-Canadians, Native peoples, and immigrants; and the Multiculturalism Act of 1988 committed federal resources to support Canada's goals in cultural pluralism, i.c. programs in race relations, cross-cultural awareness, heritage cultures and languages, and community participation (Bourhis, 1984a, 1984b, 1984c; Breton, 1980; Burnaby, 1987; Canada, 1988; Cummins, 1984a, 1984b, 1984c, 1988; Driedger, 1984; Driedger \& Hengstenberg, 1986; Ducharme, 1984; Foucher, 1985; Heller, 1984; Isajiw, 1984; Joy, 1972; Lachepelle \& Henripin, 1982; Mallea, 1984, 1989; McLend, 1983; Rubin, 1971, 1983; Wardhaugh, 1983, $1986,1987)$.

\section{Directions in the Manitoba Legislature}

Manitoba adopted the national experiment in "Multiculturalism Within a Bilingual Framework" as its own when the law-makers placed bilingualism and bilculturalism atop the province's educational agenda. Acting on the findings of the 1959 Royal Commission on Education and in accord with the 1969 Official Languages Act, the Manitoba Legislature restored French language education rights by virtue of the Manitoba Public Schools Act of 1970. Thus English and French became the official languages of instruction in Manitoba public 
schools. However, the issue of "nonofficial" languages, Native languages, land immigrant languages, remained unaddressed in Manitoba until the 1980s when law-makers, in response to the nation-wide debate surrounding Canadian repatriation, passed two additional pieces of school language legislation: the Manitoba Public Schools Act of 1980 and an amendment in 1982. These laws, a response to the Canadian Charter of Rights and Freedoms, guaranteed all linguistic minorities the right to educate their children "in the official langulage of their choice" (Ducharme, 1984, p. 1).

\section{Language Education "Choice" in Manitoba Public Schools}

Today, the Canadian Secretary of State, the Manitoba Department of Culture, Heritage, and Citizenship, and the Manitoba Department of Education and Training promote "Multiculturalism Within a Bilingual Framework" or language education "choice" in Manitoba public schools. The Department of Education and Training currently administers policies and coordinates resources to support three models of language education "choice": "Official" language programs, "Heritage" language programs including bilingual programs and language enrichment programs, and "Native" language programs, all illustrated in figure 1 (Manitoba Education, 1983a, 1983b, 1988, 1989a, 1989b, 1989c, 1990).

In a policy statement dated June of 1990 , the Manitoba Minister of Education and Training, speaking in English and French, reaffirmed Manitoba's commitment to language choice by outlining standards for programs in "Francais and Immersion . . . Multiculturalism . . . Native language and studies ... [and] bilingual programs in languages other than English and French." Central to the Minister's "blueprint" for student success in the twenty-first century are the concepts of English-French dualism, cultural pluralism, and community participation (Manitoba, 1990, pp. 8-23):

Answering the Challenge . . provides a blueprint for the future development of . . . curriculum, . . . assessment, evaluation and reporting over the next decade .... It also addresses changing societal expectations of the educational 
LANGUAGE EDUCATION "CHOICE" IN MANITOBA

(a) "Official" Language Programs

English

Francais

French Immersion

(b) "Heritage" Language Programs

Bilingual Programs

English-German

English-Hebrew

English-Ukrainian

Language Enrichment Programs

Chinese

Filipino

Hutterian German

Icelandic

Italian

Latin

Polish

Porruguese

Punjabi

Spanish

Yiddish

(c) "Native" Language Programs

Chipewyan

Cree

Dakota/Sioux

Island Lake Cree

Ojibway

Figure 1. Language education "choice" in Manitoba. Manitoba educational policy mandates three models of language education "choice" in public schools: (a) "Official" language programs, (b) "Heritage" language programs, and (c) "Native" language programs. Source: Manitoba (1989a, 1990). 
system . . . . the policy directions . . . are the result of an extensive review process and reflect the input of the various partners in the educational process: parents, educators, post-secondary institutions, business and professional organizations . . . . the goal of high school education is to provide students with the knowledge, skills, confidence and values that enable them to lead successful lives and make positive contributions to society ... to handle successfully the demands of the 21st century (Manitoba Ministry of Education and Training, 1990, p. 1).

While the trend toward "Multiculturalism Within a Bilingual Framework" presents a unique set of problems to Canadian educators, linguists, and policy-makers, the direction clearly introduces a different set of standards for language planning and policy in education. In Manitoba public schools, for example, three language education policies have prevailed since the 1960s. One, Canadian "Multiculturalism Within a Bilingual Framework" replaces "One People, One Language, One School System" as a rationale for language planning and educational policymaking in Manitoba public schools. Two, the Canadian Charter of Rights and Freedoms, enshrined in the Canadian Constitution, mandates choice in decisions of minority language education rights in local communities. And three, the Manitoba Ministry of Education prescribes a process that involves community participation -- parents, educators, post-secondary institutions, and business and professional organizations -- in local school reform. It appears that Canadian educators, linguists, and policy-makers have indeed stepped back imaginatively to ask "What if . . . Why . . . How did it start?"

\section{A TELLING STORY OF LANGUAGE IN ANGLO-AMERICAN SCHOOLING}

Given this history, this telling story of language in Anglo-American schooling, framed in Manitoba schools between 1890 and 1990, a question surfaces. Who in the Mennonite speech community today uses what language with whom, when, where, and why? What went on then in the aftermath of an English-only act, a compulsory school attendance law, and an appeal for language education rights that took the Mennonite speech community to the Canadian Supreme Court and the British Crown itself? And what's going on now in the aftermath of 
"Multiculturalism Within a Bilingual Framework"? In the particular situation of one-hundred years of contact between sidestream language and culture in a Mennonite speech community in Manitoba and mainstream language and culture in Canada, illustrated in figure 2, is there continuity, change, and compartmentalization? Is it possible that narrower issues of "change and continuity" -- micro-issues of sidestream ethnoculture -- reflect broader issues of "shift and constancy" -- the macro-issues of mainstream ethnoculture? Is it possible to know and to follow the intricate processes of change and continuity? If so, how so? To answer these questions, I turn my attention toward ethnography as "community science," to concepts of ethnolinguistic dualism, and to a centuries-old tradition of diglossia. 

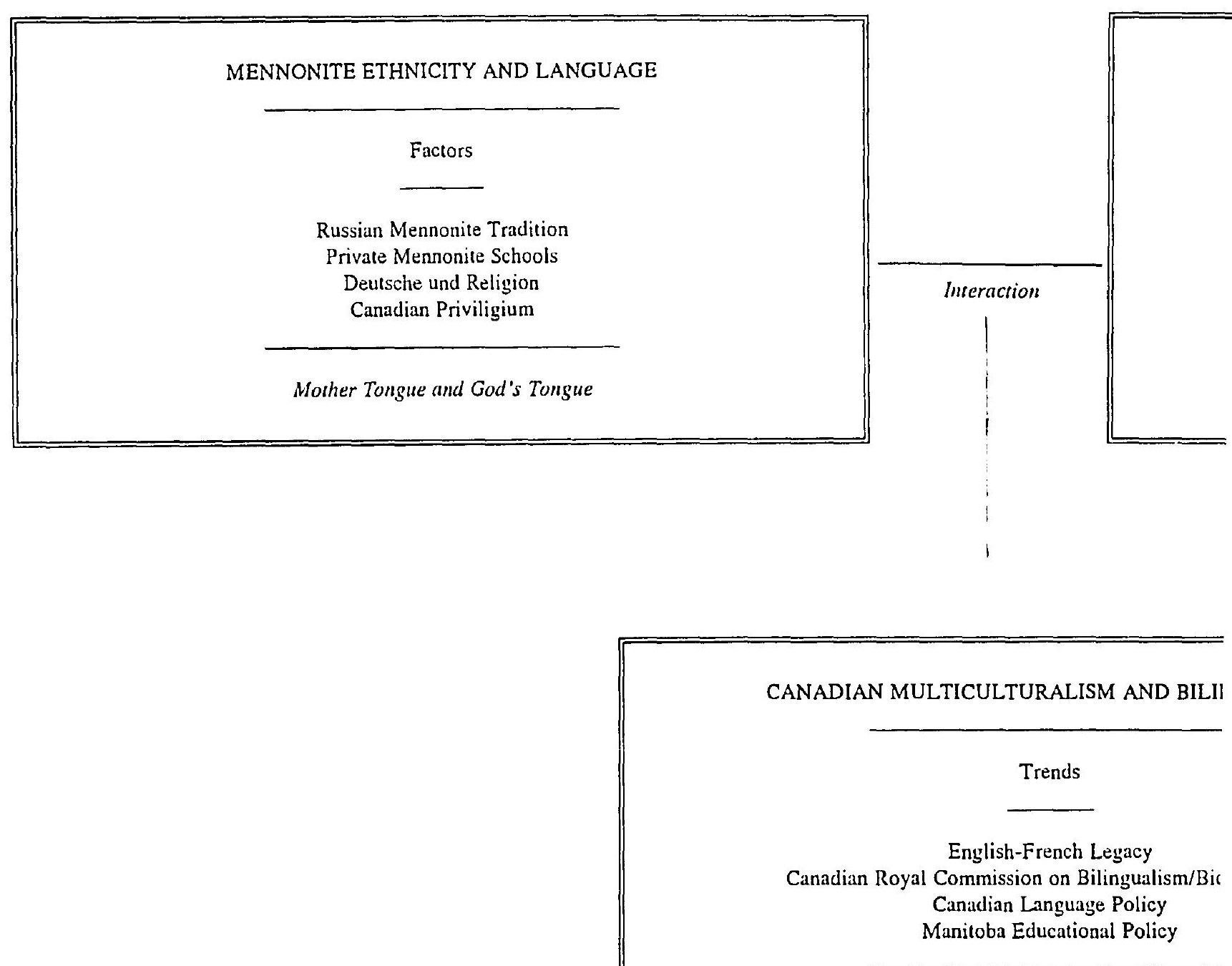

Official Languages, Heritage Languages, Native

Figure 2. An historical problem in Anglo-American s 


\section{CANADIAN CULTURE AND HERITAGE}

Factors

British-Canadian Tradition

Public Sectarian Schools

Interaction

English-only and Union Jack

Canadian Nationalism

Queen's Tongue

\section{IN MULTICULTURALISM AND BILINGUALISM}

Trends

English-French Legacy

a Royal Commission on Bilingualism/Biculturalism

Canadian Language Policy

Manitoba Educational Policy

Languages, Heritage Languages, Native Languages

;torical problem in Anglo-American schooling. 



\title{
CHAPTER II
}

\section{TOWARD ETHNOGRAPHY AS "COMMUNITY SCIENCE": AN INTERDISCIPLINARY MODEL OF A SPEECH COMMUNITY}

\begin{abstract}
Singling out ethnolinguistic diversity as an historical problem and an enduring question in education, national development, and cross-cultural communication, an ethnographer said . . .
\end{abstract}

The role of language in thought and culture cannot be assessed for bilinguals until the role of each language is assessed; but the same is true for monolinguals since in different societies language enters differentially into educational experience. . . . What is needed, then, is a general theory and body of knowledge within which diversity of speech, repertoires, ways of speaking, and choosing among them find a natural place. Such a theory and body of knowledge are only now being built in a sustained way (pp. 38-40).

Del Hymes (1986)

\section{A TRADITION OF ETHNOGRAPHY}

Two ways of speaking and two ways of knowing have marked Mennonite language and ethnicity for at least four centuries (R. Epp, 1986; Goertzen, 1972; Hostetler, 1974, 1980; Klassen, 1989; Loewen, 1986; Mireau, 1965; Reimer, Reimer, \& Thiessen, 1983). This state of ethmolinguistic dualism, a term used here to link language and ethnicity in a Mennonite speech community, is defined as a particular situation in which two traditions of one language, an oral tradition and a literary tradition (R. Epp, 1987; Klassen, 1989; Loewen, 1986; Reimer, 1983), are used to interpret two worlds, one secular and one sacred (Loewen, 1980, pp. 85-95; Driedger, 1980, pp. 123-136), and to compartmentalize two "fields" of social interaction (Bales, 1979), a prosaic "here and now," and a utopic "hereafter" (Kanter, 1972; Manuel \& Manuel, 
1979). And while the term ethnolinguistic dualism is not limited singly to a Mennonite speech community, not to any one time, any one place, nor any one language family (Ferguson, 1959, pp. 336-337), the historical problem and the enduring question of ethnolinguistic diversity in multilingual, multicultural societies have gone relatively unnoticed until the middle of the twentieth century when the "human sciences" -- language, anthropology, sociology, psychology, and education -- converged in ethnography, a community science (Gumperz \& Hymes, 1986; Hymes, 1980).

Today, leading researchers advance the concepts of this ethnolinguistic dualism, namely diglossia (Ferguson, 1959), diglossia with and without bilingualism (Fishman, 1967), bilingualism with and without diglossia (Fishman, 1967), and di-ethmia (Fishman, 1980), as ways of explaining the origin, maintenance, and change of conditions in which two forms of language exist side-by-side in a speech community, each with a separate role or function. To develop these models, researchers looked not to the paradigm $(K u h n, 1962)$ in the social sciences derived from the natural sciences -- the "hard-nosed, quantitative, experimental socialscience" approach to "data, proofs, and tests" influenced by the "hypothetico-deductive" tradition. Rather they pointed to the paradigm in the human sciences derived from the humanities (Hymes, 1983) - the "holistic and nonquantitative 'poetic' perspective" of folklore, folk linguistics, and national philologies influenced by the "descriptive-inductive" tradition (Fishman, 1985, p. 473). Thus, some linguists and social scientists, concerned with building a general theory and a body of knowledge, revived the tradition of ethnography and started a movement called sociolinguistics by linguists and social scientists, educational linguistics by linguists and educational researchers, or community science by ethnographers (Goetz \& Lacompte, 1984; Gumperz, 1968; Gumperz \& Hymes, 1986; Hymes, 1980; Wax, 1971). 
Reorienting themselves to community science, these linguists joined social scientists as a whole to redress the fundamental problem of cross-cultural and educational research, namely the problem of social scientists asking functional questions without the training to deal with the linguistic face of the problem, and of linguists neglecting social meaning, diversity, and use. Together these language and social scientists took a view that sociolinguistics itself "[did] not accept but [offered] a critique of the present partitioning of man [woman and child]" among disciplines (Hymes, 1986, p. 41). And ethnography, a holistic enterprise, permitted linguists, anthropologists, sociologists, psychologists, and educators partly to link, partly to cut across, yet partly to build between and among the ordinary practices of the disciplines.

Given this interdisciplinary framework, then, together with its "strong network of commitments . . conceptual, theoretical, instrumental, and methodological" (Kuhn, 1961, p. 42), sociolinguists revived an intellectual tradition "which holds that [humankind] cannot be understood apart from the evolution and maintenance of its ethnographic diversity" (Hymes, 1986, p. 41). With that tradition came a notion of speech community (Gumperz, 1968; Hymes, 1961, 1974, 1986; Labov, 1966, 1972; Milroy, 1980, 1986) and a discovery that one speech community differs significantly from another.

[Speech] communities differ significantly in ways of speaking, in patterns of repertoire and switching, in the roles and meanings of speech. They indicate differences with regard to beliefs, values, reference groups, norms, and the like as these enter the ongoing system of language use and its acquisition by children (Hymes, 1986, p. 42).

The interdisciplinary framework led also to some "heuristic schema" that provided for the observation and analysis of the "sociolinguistic system" of a community (Hymes, 1986, p. 52):

Sociolinguistic systems may be treated at the level of national states, and indeed, of an emerging world. My concern here is with the level of individual speech communities and groups. The interaction of language with social life is viewed as first of all a matter of human action, based on a knowledge, sometimes conscious, often unconscious, that enables persons to use language. Speech events and larger systems indeed have properties not reducible to those of the speaking competence of persons. Such competence, however, underlies communicative conduct, not only within communities but also in encounters 
between them. An adequate descriptive theory would provide for the analysis of individual communities . . . . individual systems.

Among the notions with which such a theory must deal are those of speech community, speech situation, speech event, speech act, fluent speaker, components of speech acts, functions of speech (Hymes, 1986, p. 53).

Ethnography, thus conceived theoretically and practically as the ethnography of speaking (Hymes, 1974, pp. 88-90), permitted linguists and social scientists, first, to concern themselves with integrating the human sciences holistically in community science (Hymes, 1980); second, to describe the interaction of language in community and school, both "mainstream" and "sidestream" (Fishman, 1985b); and third, to ask some questions about literacy and language development in multilingual, multicultural societies (Alatis, 1980; Alatis, Stern, Stevens, 1983; Alexiou, 1982; Dil, 1971, 1972a, 1972b, 1989; Di Pietro, 1985;

Ferguson, 1959, 1962a, 1962b, 1963a, 1963b, 1968a, 1985; A. Fishman, 1988; J. Fishman 1967, 1968a, 1971, 1972, 1983, 1985, 1989; Gumperz, 1985; Haugen, 1957, 1962, 1987;

Hymes, 1980, 1985; Rubin, 1968, 1983, 1985).

Adopting the ethnography of speaking, I return to an historical problem of language in Anglo-American society and schooling, described in Chapter $I$, and to the general question of sociolinguistic research -- Who uses what language with whom, when, where, and why? Hoping to contribute to knowledge of the links between language and ethnicity (Fishman, 1989), I start with the existence of Mother tongue and God's tongue in a Mennonite speech community, with the concept of diglossia noticed first in Charles Ferguson's (1959) seminal work "Diglossia" in Word, and next in Joshua Fishman's (1967) explorative study "Diglossia With and Without Bilingualism" in The Joumal of Social Issues. These studies explain the phenomenon of linguistic dualism, link it to ethnicity, and shed light on the issues of origin, maintenance, and shift (Fishman, 1966, 1967, 1968a, 1971a, 1971b, 1972a, 1972b, 1980, 1983, 1985a, 1985b, 1986, 1989). In the case of Mennonite speech communities in Canada, these studies describe the historical conditions giving rise to the complex relationship between and among vernacular 
German, classical German, and Canadian English. They further raise some issues of maintenance and shift that relate to points of contact between sidestream and mainstream language in compulsory Anglo-American schools (Daniels, 1989; Hymes, 1980; Keim, 1975; Mallea, 1989). An essential study, too, is Del Hymes' (1961) "Functions of Speech: An Evolutionary Approach" in Anthropology and Education. This essay is the first word on the perspective known today as "the ethnography of speaking" (Hymes, 1962, 1964, 1972, 1974, $1980,1986)$ and an important contribution to the nascent field of "educational linguistics" (Hymes, 1961, 1962, 1980; Spolsky, 1978, 1986; Stubbs, 1985). Hymes' ethnography of speaking together with Robert Bales' (1979) SYMLOG, a system for the multiple-level observation of groups and Lesley Milroy's (1980) Language and Social Networks, a soon-to-be "classic" in sociolinguistics, connect the interactive concept of ethnography to the interactive nature of ethnographer.

Precursors all, these pioneering studies link the disciplines of linguistics and social science as a whole, explain the particular situation of ethnolinguistic dualism in a Mennonite speech community, and address issues related to the historical problem of sidestream language and ethnicity mainstream schools. These studies further nelp me deal with problems in the literature associated with social scientists undertaking language research without linguistic training (Driedger, 1984; Driedger \& Hengstenberg, 1986; Redekop, 1987; Urry, 1978), and some contradictions in the literature related to English and German language scholars taking steps to standardize a language variety and neglecting diversity, use, and meaning (Klassen, 1989; Loewen, 1988; Reimer, 1983; Rempel, 1984). Eventually, these important firsts that lead to some answers to the all-encompassing question of who uses what language with whom, when, where, and why. 


\section{THE QUESTION OF MOTHER TONGUE AND GOD'S TONGUE: FERGUSON'S (1959) SPEECH ACT ON "DIGLOSSIA"}

\section{Charles Ferguson noticed the phenomenon of Mother tongue and God's tongue and} coined it diglossia, a term he modelled on the French word diglossie and related to the European notion bilingualism. He introduced the term as "one particular kind of standardization ... [ [in which] two varieties of a language exist side by side throughout the community, with each having a definite role to play" (Ferguson, 1959, p. 325). His article "Diglossia" first appeared in a 1959 issue of Word and is now considered a seminal statement in the literature on linguistic dualism. The journal article introduced the classic concept and led, after three decades of language research, to an almost universal acceptance of an assumption about "bilingualism without diglossia":

When Charles Ferguson first coined the term "diglossia" he set off a flurry of activity directed toward an examination of the relationships between functionally differentiated languages . . . It became almost universally accepted that bilingualism without diglossia is a transitory situation leading inevitably to unstable bilingualism and, eventually, monolingualism (Dodson, 1989, p. 387).

The assumption held in Ferguson's (1959) pioneering study of diglossia in four speech communities; it held later in his studies of bilingualism in multilingual societies in Asia, Africa, Europe, and Latin America (Ferguson, 1960, 1962a, 1963a, 1966a, 1968a, 1985); and, apparently, it holds loday, as this study will reveal, in a Mennonite speech community in Canada.

\section{Ferguson's Pioneering Research on Diglossia}

Ferguson, an observer of bilingualism in speakers and multilingualism in societies, noticed that different languages were commonly assigned different tasks. He noted particular speakers who often used one language variety in one setting and another variety at a different time and place. Ferguson later called this phenomenon diglossia and the situation diglossic, for they represented a particular dual relationship between language form and social meaning: 
DIGLOSSIA is a relatively stable language situation in which, in addition to the primary dialects of the language (which may include a standard or regional standards), there is a very divergent, highly codified (often grammatically more complex) superposed variety, the vehicle of a large and respected body of written literature, either of an earlier period or in another speech community, which is learned largely by formal education and is used for most written and formal spoken purposes but is not used by any sector of the community for ordinary conversation (Ferguson, 1959, p. 336).

Ferguson found this phenomenon and this situation to be "widespread, although rarely mentioned let alone satisfactorily described" (Ferguson, 1959, p. 326). So his contribution to the codification of diglossia amounted to a pionering study in language research.

Interested in solving the problems of language development and language standardization, Ferguson assembled the necessary language data. Systematically, he codified the data, first, by applying a general question of the high-low factor to four speech communities under study, and second, by applying particular questions to speech communities which met the criterion. The "high-low" language factors and the nine rubrics of diglossia remain the criteria for the classic model of diglossia.

\section{"High-Low" Language Criterion and Rubrics}

Having collected historical and descriptive data, Ferguson found that four speech communities, the Arabic, Modern Greek, Swiss German, and Hairian Creole communities, all met certain "high-low" language factors. He found in each community, for example, a stable relationship between two varieties of the same language, a "superposed" or "classical" variety called "high" variety or simply $\mathrm{H}$ and a "vernacular" variety called "low" variety or simply $\mathrm{L}$

(Ferguson, 1959, p. 327):

For convenience of reference the superposed variety in diglossia will be called the $\mathrm{H}$ ("high") variety or simply $\mathrm{H}$, and the regional dialects will be called $\mathrm{L}$ ("low") varieties or, collectively, simply L (Ferguson, 1959, p. 327).

He also found $\mathrm{H}$ to be a variety which speakers learned formally and which was the vehicle of a large and respected body of literature. Concurrently, he discovered $L$ to be a 
variety which speakers acquired naturally as a mother tongue. He also noticed that the four speech communities differentiated the two varieties not only in use, but also in name, for each speech community named $\mathrm{H}$ and $\mathrm{L}$ in the "High," and each re-named $\mathrm{H}$ and $\mathrm{L}$ in the "Low." Figure 3 below charts data from Ferguson's application of the high-low criterion to the four speech communities, or as he called them, the "defining languages." Immediately following the names of the defining languages are the names for their $\mathrm{H}$ and $\mathrm{L}$. I have included data from my application of the "high-low" criterion to a Mennonite speech community.

Once Ferguson confirmed the presence of the high-low factor in the four defining languages, he systematically explained the origin of diglossia under nine rubrics (Fasold, 1984, p. 34): function, prestige, literary heritage, acquisition, standardization, stability, grammar, lexicon, and phonology (Fasold, 1984. p. 34; Ferguson, 1959, pp. 328-336).

Function. A critical feature of diglossia has to do with the situations in which $\mathrm{H}$ and $\mathrm{L}$ are used. Speakers know that in one situation, only $H$ is appropriate, and in another only $L$ is well-chosen. A few situations entail slight overlapping. In the case of the four defining languages, speakers in the speech communities understand the norms of language choice and social situation and use $\mathrm{H}$ and $\mathrm{L}$ appropriately. Figure 4 illustrates the situations and choices of $\mathrm{H}$ and $\mathrm{L}$ in diglossia. To use the wrong variety in an inappropriate situation is a serious social error. No speaker regularly uses $\mathrm{H}$ as a medium of ordinary conversation. Any attempt to do so is considered pedantic or artificial or in some sense disloyal to the speech community. In each defining language, typically, a speaker reads aloud from a newspaper in $\mathrm{H}$ and discusses its contents in $\mathrm{L}$, or a speaker listens to a lecture in $\mathrm{H}$ then discusses it, "often with the lecturer himself, " in L. Typically, too, a poet writes poetry in both $\mathrm{H}$ and L, but the status of the two types of poetry is different. Only poetry written in $\mathrm{H}$ is felt to be "real" poetry (Ferguson, 1959 , pp. 328-29, 336). 


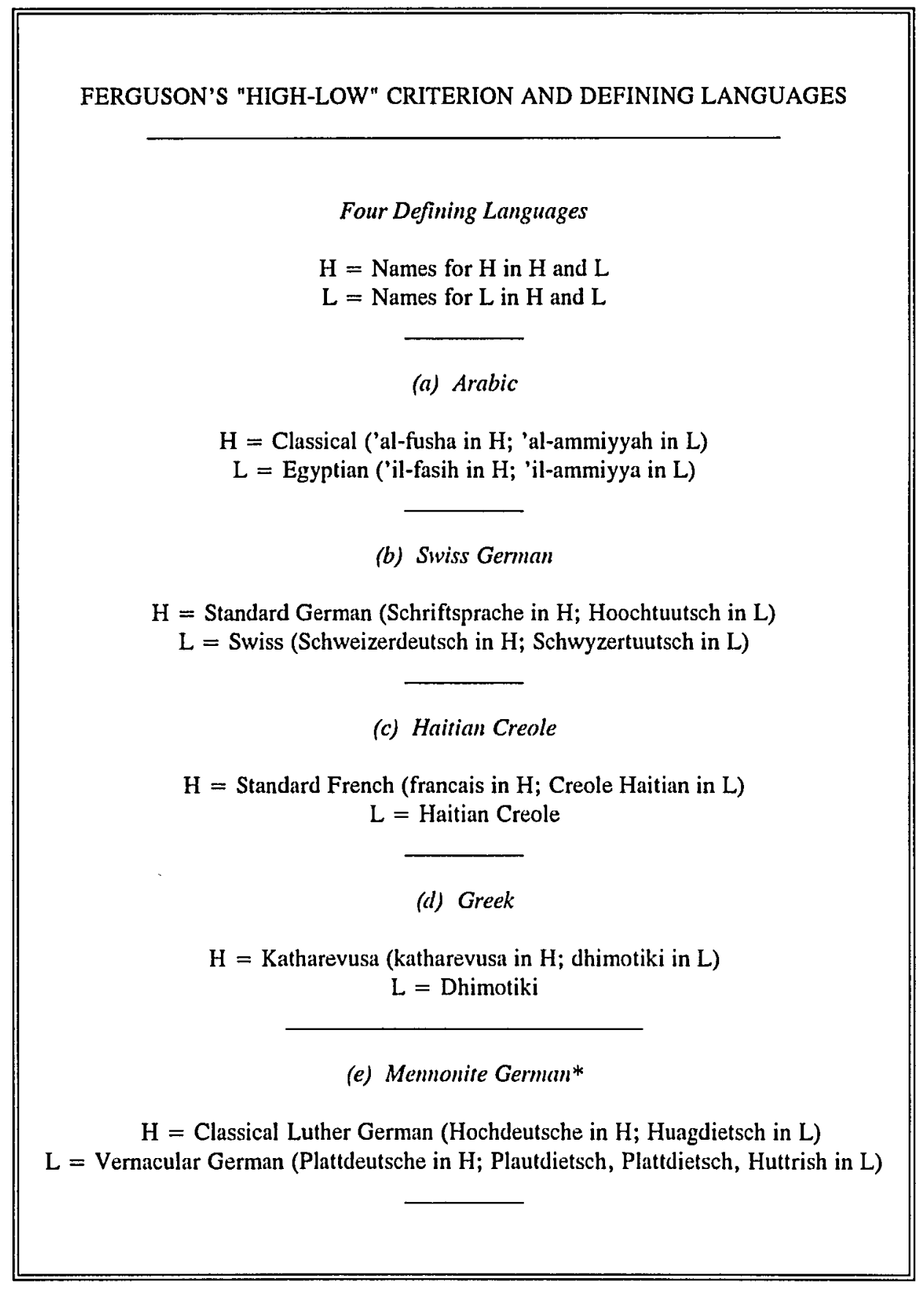

Figure 3. Ferguson's "high-low" criterion and defining languages.

Ferguson applies the "high-low" criterion to four speech communities or defining languages: (a) Arabic, (b) Swiss German, (c) Haitian Creole, and (d) Greek, each with names for H and L. Source: Ferguson (1959, p.

327). (*Ferguson's "high-low" criterion can be applied to [e] Mennonite German with names for $\mathrm{H}$ and L.) 
FERGUSON'S "FUNCTION" CRITERION

Choices Diglossic Situations

H L

H Sermon in church or mosque

L Instructions to servants, waiters, workers

H Personal letter

H Speech in parliament, political speech

H University lecture

L Conversations with family, friends, colleagues

H News broadcasts

L Radio "soap opera"

H Newspaper, editorial, news story, caption on picture

L Caption on political cartoon

H Poetry

L Folk literature

Figure 4. Ferguson's "function" criterion. Ferguson applies the "function" criterion to diglossic situations and illustrates the choices speakers make between $\mathrm{H}$ and $\mathrm{L}$ varieties of language. Other criteria include prestige, literary heritage, acquisition, standardization, stability, grammar, lexicon, and phonology. Source: Ferguson (1959, p. 329). 
Prestige. In diglossic communities, speakers typically share the attitude that $\mathrm{H}$ is superior, more logical, and more beautiful than $\mathrm{L}$ and that $\mathrm{L}$ is inferior. For example, some educated speakers say they do not speak L. Some go so far as to say L does not exist, that it is not a language. Interestingly, the same speakers can be observed to use L especially when they talk with their mothers, children, or servants. The attitude persists not as a lie, but rather as a form of self-deception.| On the other hand, some uneducated speakers who understand little or no $\mathrm{H}$ insist that it should be used in formal situations connected to religion, politics, and education. In the case of Greek, the language of the New Testament and karharevusa is felt to be the same language; and in the case of Arabic, the language of the Koran is believed to be God's tongue, i.e. "to be outside the limits of space and time, to have existed "before" time began with the creation of the world" (Ferguson, 1959, p. 330).

Literary Heritage. In each of the defining languages, a great literary tradition is tied to the history of the speech community and a highly valued canon written in H. Contemporary writers carry on the great tradition of writing in $\mathrm{H}$, and consider it to be good literary taste to use expressions from an earlier period in current written work. In all defining languages, the literary tradition is remote from contemporary society. In the cases of Greek and Arabic, the tradition is rooted in the distant history of the speech community itself; and in the cases of Haitian Creole and Swiss German, the tradition is tied to a distant territory, to a different speech community allogether (Ferguson, 1959, p. 36).

Acquisition. A significant feature of diglossic situations is the fact that the means for learning $L$ differs from the method for acquiring $H$. In the former situation, children learn $L$ naturally at home as a mother tongue and on the playground from other children. Adults use $\mathrm{L}$ to speak with children, parents, and servants, and among themselves. Alternatively, children and adults learn $\mathrm{H}$ as an "add-on" or a "superposed" variety after $\mathrm{L}$ has been acquired. Children may hear $\mathrm{H}$ from time to time, but they acquire $\mathrm{H}$ formally as a language of instruction in 
school, a language of catechism in churches and parochial schools, or a language of the classical tradition through tutelage. Given the pattern for learning $\mathrm{L}$, it is a fact that all speakers learn the $L$ variety and apply the implicit rules of $L$ grammar with "near perfection" even though many say "that $L$ has no grammar and that $L$ speech is the result of the failure to follow the rules of $\mathrm{H}$ grammar. " In the situation of $\mathrm{H}$, on the other hand, it remains a fact that some speakers may never learn the $\mathrm{H}$ variety at all. Those speakers who do acquire $\mathrm{H}$ memorize, apply, and recite explicit rules of $\mathrm{H}$ grammar, often with limitations (Fasold, 1984, p. 37; Ferguson, 1959, p. 331)).

Standardization. Common to each of the defining languages is a strong tradition of standardization, a process by which governments, schools, churches, academies deliberately take steps to codify the $\mathrm{H}$ variety formally. Grammars, dictionaries, orthographies, pronunciation keys, usage glossaries, and style books are the instruments of standardization. In some cases, the process can involve steps to change language attitudes by symbolizing or identifying the use of the $\mathrm{H}$ variety functionally as a mark of prestige. Rarely is the process of standardization undertaken with comparable studies of the $\mathrm{L}$ variety. If and when diglossic communities attempt to standardize the $L$ variety, the studies tend to be recent, to be written by scholars outside the community or novices inside the community. In either case, studies of $\mathrm{L}$ are thought at best to exhibit informal standards with wide variation in spelling rules, pronunciation, grammar, and vocabulary, at worst to be corrupt (Fasold, 1984, p. 37; Ferguson, 1959, p. 331-332;

Wardhaugh, 1986, pp. 30-31).

Stability. Diglossia is a stable phenomenon that may persist hundreds, even thousands of years. Some argue that diglossia is "required" in order to maintain more than one variety in one speech community. In cases of competition between $\mathrm{H}$ and $\mathrm{L}$ varieties, speakers tend to resolve tension by developing mixed, intermediate forms of the language which share classical 
and vernacular features of $H$ and $L$. Borrowing from $H$ to $L$ is usual; however, use of $L$ in $H$ does occur (Fasold, 1984, p. 37; Ferguson, 1959, pp. 332-33).

Grammar. In cases of diglossia, the grammars of $\mathrm{H}$ differ considerably from the grammars of $\mathrm{L}$. Features noticeably present in $\mathrm{H}$ and absent in $\mathrm{L}$ may include case, number, and gender of nouns, tense and mood of verbs, and a syntax of introductory phrases and subordinate clauses. Typically, the $\mathrm{H}$ system of grammar is based on elaborate categories and structures while the $\mathrm{L}$ system of grammar is reduced or absent. So, it appears that the $\mathrm{L}$ grammar is of a different sort, usually less inflexted (Ferguson, 1959, pp, 333-334).

Lexicon. Characteristically, the diglossic lexicon features some words that occur in both the $\mathrm{H}$ and the $\mathrm{L}$ vocabularies and some words that occur in either one or the other vocabulary. Words marked as scholarly or technical, "nuclear fission" for example, appear in the $\mathrm{H}$ lexicon but not in the L. Conversely, words representing homey objects or farm implements occur in $\mathrm{L}$ but have no equals in $\mathrm{H}$. But the striking feature of the lexicon is the existence of paired items. For example:

one $\mathrm{H}$ one $\mathrm{L}$, referring to fairly common concepts frequently used in both $\mathrm{H}$ । and $\mathrm{L}$, where the range of meaning of the two items is roughly the same, and ' the use of one or the other immediately stamps the utterance or written sequence as $\mathrm{H}$ or $\mathrm{L}$ (Ferguson, 1959, p. 334).

One example, from Greek, is the pair of words for "wine": the H word is inos, and the L word is krasi. In a restaurant, the menu will say inos and the patron will ask for krasi from the waiter. At first glance, the English words children and kids appear to be likewise paired items; but in English, both words may be written and spoken. In diglossic communities, typically speakers use $H$ words when writing and $L$ when talking (Ferguson, 1959, pp. 334-35). $i$

Phonology. The range of sounds differs both across $\mathrm{H}$ and $\mathrm{L}$ varieties and across speech communities. In the case of Greek, the range of phonological variation is narrow, in the case of Arabic and Haitian Creole, moderate, and in the case of Swiss German, wide. The H and $L$ phonemes as well as the ways of combining $H$ and $L$ sounds seem to be derived from the 
same phonological system. Given one system of phonology, the $L$ may be a subsystem or a parasystem of $\mathrm{H}$ (Fasold, 1984, p. 38; Ferguson, 1959, p. 335-36).

\section{The Issues of Origin and Stability}

Finally, Ferguson addressed the issues Iof origin and stability in his 1959 study. He described diglossia as "widespread" and, given favorable conditions, likely to eventuate at any time, in any place, within any linguistic family. He found three factors to be critical to the origin, maintenance, and stability of diglossia in a speech community: a sizable body of literature, a limited access to literacy, and a suitable period of time to the condition of stability. He said, also, if and when:

(1) there is a sizable body of literature in a language closely related to (or even identical with) the natural language of the community, and this literature embodies, whether as source (e.g. divine revelation) or reinforcement, some of the fundamental values of the community;

(2) literacy in the community is limited to a small elite;

(3) a suitable period of time, on the order of several centuries, passes from the establishment of (1) and (2) (Ferguson, 1959, p. 338);

then diglossia will likely occur, gain acceptance, and endure for centuries perhaps. However, he continued, if and when certain trends appear in the speech community, trends toward:

(a) more widespread literacy (whether for economic, ideological or other reasons);

(b) broader communication among different regional and social segments of the community (e.g. for economic, administrative, military, or ideological reasons);

(c) desire for a full-fledged standard "national" language as an attribute of autonomy or of sovereignty (Ferguson, 1959, p. 338);

then, leaders will likely call for a unified community, a single language, and the exclusive adoption of either $\mathrm{H}$ or $\mathrm{L}$ as the standard. Concerning the desire for autonomy and sovereignty, he said, "The arguments explicitly advanced seem remarkably the same from one [speech community] to another" (Ferguson, 1959, p. 338). Ferguson concluded that the prognosis for 
diglossia in some situations could be continued stability. In other situations, though, pressures for increased literacy, broader communication, and the development of nationalism could blur distinctions between $\mathrm{H}$ and $\mathrm{L}$ and eventually lead to the demise of the diglossic situation. A model of Ferguson's diglossia, figure 5, identifies conditions associated with the origin of diglossia, trends associated with the demise of diglossia, and "high-low" factors associated with classic diglossia.

Although Ferguson himself characterized his 1959 paper on diglossia to be "preliminary" and "impressionistic," his study is nevertheless considered the definitive statement on diglossia. Written while he was at Harvard's Center for Middle Eastern Studies, he appealed to linguists for further study of diglossia:

Study of such matters as diglossia is of clear|value in understanding processes of linguistic change and presents interesting challenges to some of the assumptions of synchronic linguistics. Outside linguistics proper it promises material of great interest to social scientists in general, especially if a general frame of reference can be worked out for analysis of the use of one or more varieties of language within at speech community. Perhaps the collection of data and more profound study will drastically modify the impressionistic remarks of this paper, but if this is so the paper will have had the virtue of stimulating investigation and thought (Fergulson, 1959, p. 340).

Clearly, Ferguson's statement on diglossia achieved the virtue of stimulating further investigation of the question "Who uses what language with whom?" Among the first to respond to his appeal was Fishman (1967) whose examination of mother tongue, god's tongue, and the queen's tongue not only revised and expanded Ferguson's (1959) concept of diglossia but also carefully distinguished it from bilingualism.

A QUESTION OF MOTHER TONGUE, GOD'S TONGUE, AND THE QUEEN'S TONGUE: FISHMAN'S (1967) SPEECH ACT ON DIGLOSSIA AND BILINGUALISM

Joshua Fishman took heed of Ferguson's appeal for further study of diglossia. His article "Diglossia With and Without Bilingualism; Bilingualism With and Without Diglossia" 

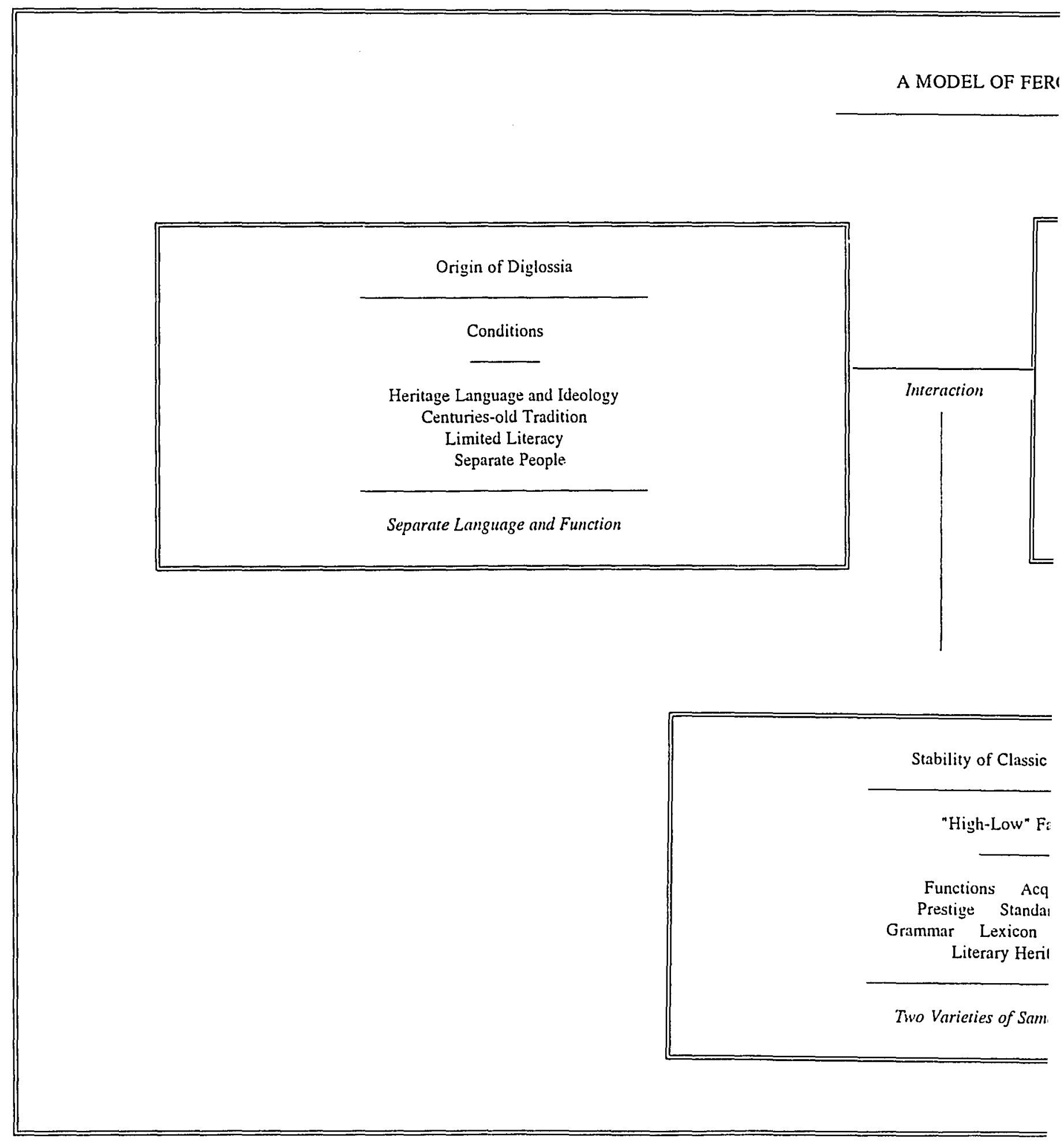

Figure 5. A model of Ferguson's । 

A MODEL OF FERGUSON'S DIGLOSSIA

\begin{tabular}{|c|c|c|}
\hline & Demise of Diglossia & \\
\hline & Trends & \\
\hline \multirow[t]{2}{*}{ Interaction } & \multicolumn{2}{|c|}{$\begin{array}{c}\text { National Language and Ideology } \\
\text { Modern-day Standards } \\
\text { Widespread Literacy } \\
\text { United People }\end{array}$} \\
\hline & Mixed Langu & \\
\hline
\end{tabular}

Stability of Classic Diglossia

"High-Low" Factors

Functions Acquisition

Prestige Standardization

Grammar Lexicon Phonology Literary Heritage

Two Varicties of Same Language

Figure 5. A model of Ferguson's diglossia. 

f:rst appeared in a 1967 issue of The Journal of Social Issues. The article is now considered an important contribution to the literature on diglossia and bilingualism because it addressed a major concern at the time, the concern that the term diglossia could "degenerate into just . . a a fancy synonym for bilingualism" (Stewart, 1962, p. 159); and it urged social scientists and linguists as a whole to redress the problem in the literature on bilingualism and bilingual education. The problem, Fishman said, could be remedied if linguists, sociologists, and psychologists were to link traditions in language research:

The psychological literature on bilingualism is . . more extensive than its sociological counterpart . . . workers in the former field have failed to establish contact with those in the latter. In the past decade a very respectable ... sociologically oriented . . . literature has developed dealing with bilingual societies. It is the purpose of this paper to relate these two research traditions to each other by tracing the interaction between their two major constructs: bilingualism (on the part of psychologists) and diglossia (on the part of sociologists) (Fishman, 1967, p. 29).

A decade later, after linguists and social scientists as a whole established linkages and compared their research on linguistic diversity, use, and meaning, Fishman (1980) clarified the distinction between individual bilingualism and societal diglossia:

The relationship between individual bilingualism and societal diglossia is far from being a necessary or casual one, i.e. either phenomenon can occur with or without the other ... It is but one more example of the weak relationship obtaining between various individual social hehaviors and their corresponding societal counterparts . . . . Thus diglossia differs from bilingualism in that it represents an enduring societal arrangement, extending at least beyond a third generation period, such that two "languages" each have their secure, phenomenologically legitimate and widely implemented functions (Fishman, 1980 , p. 3).

In the same article, an authoritative statement in The Journal of Multilingual and Multicultural Development on the issues of language maintenance and shift, Fishman (1980) called attention

to a related distinction, the one between individual biculturalism and societal di-ethnia:

Just as diglossia is the stable, societal counterpart to individual bilingualism, so di-ethnia is the stable, societal counterpart to individual biculturalism. Diethnia requires societal compartmentalization as well as institutionally protected functional specificity. These desiderata are hard to attain and to retain -- both ideologically and structurally -- under "modern", interactive, 
mobile and individualistic urban industrial conditions. However, some groups have intuitively or consciously, displayed a talent for exactly such arrangements. Much bilingual education unknowingly leads to transitional rather than to stable accommodations in the areas of language and culture (Fishman, 1980, p. 3).

Finally, Fishman examined those groups in the urban industrial context that consciously and unconsciously displayed a talent for attaining, retaining, and reviving language and ethnicity. In an impressive collection of research spanning more than two decades, Fishman presented evidence of "the widespread North American and Western European 'ethnic revival" (Fishman 1977, 1980, 1982, 1983, 1984, 1985). He linked similar phenomena among indigenous minorities in North America and Europe, among "non-Founding minorities in Canada, and among Euro-immigrants in Australia. Of The Rise and Fall of the Ethnic Revival, Fishman (1985) said:

[The] "ethnic revival" of the mid-60s to mid-70s . . . was a period in which the Western capitalist uniformizing ethos was found wanting in many ways, by many groups, and in many places ... . the "central idea" was found profoundly disappointing . . . due to its purported materialism, violence, intrusiveness, bureaucracy, demoralization, lack of warmth . . . its apparent lack of Gemeinschaft . . . (whether in terms of . . one's own kind . . . or . . . purely human, interactional terms) (Fishman, 1985, p. xiii).

Any theory of the ethnic revival . . must cope, therefore, with its cooccurance in time with both indigenous and immigrant revivals in many and quite separate parts of the Western world (Fishman, 1985, p. 508).

So, Fishman's contribution to the literature on ethnolinguistic dualism included a 1967 statement on individual bilingualism and societal diglossia, a 1980 statement on individual biculturalism and societal di-ethnia, and a 1985 statement on an ethnic revival, all of which raised the important issues of language maintenance and shift in education.

Fishman's Pioneering Extension of Diglossia

Fishman $(1967,1980)$ borrowed Ferguson's (1959) high-low criterion to designate the "superposed" or classical variety in cases of diglossia. There, however, Fishman departed from Ferguson to extend diglossia beyond its original restriction of two varieties of a language. 
Specifically, Fishman (1967) de-emphasized Ferguson's "two . . . varieties of the same language" (Ferguson, 1959, p. 325, italics mine), and he extended the range of linguistic relatedness along a continuum that recognized the presence of "several separate codes, " on one hand; and the presence of "separate dialects, registers, or functionally differentiated language varieties of whatever kind," on the other hand (Fishman, 1972, p. 92). As a consequence, Fishman altered Ferguson's notion structurally to include languages or codes, registers, and styles within the concept of diglossia and functionally to include "use-oriented" and "useroriented types of diglossia (Britto, 1986, pp. 35-40).

Fishman (1967) also borrowed Ferguson's (1959) symbol H to designate the superposed variety or classical variety. Fishman compared $H$ to "no one's mother tongue, "the variety that is typically leamed in school, govemment, or church (Fishman, 1980, p. 4); and he contrasted $\mathrm{L}$ as a universally available and spoken mother tongue, the variety acquired naturally in the home and used every day. Fishman applied these extended criteria to cases of diglossia found in Arabic, Swiss German, Haitian Creole, and Greek (Ferguson, 1959); Spanish and Guarani (Rubin, 1962, 1966); Hebrew and Yiddish (Fishman, 1965, 1972); and Old Mennonite and Old Order Amish (Hostetler, 1963, 1974, 1980; Kloss, 1966). From these comparative studies, he observed four types of diglossia. Figure 6 illustrates Fishman's types of diglossia, classifies the relationship between $\mathrm{H}$ and $\mathrm{L}$, and provides examples of each case. Additionally, Fishman singled out the Old Order Amish speech community (Mennonite speech community) as a "complex case" of diglossia in which speakers use two Hs and one L. This complex pattern, he pointed out, revealed one H (Luther Bible German or classical German in the case Mennonites) to be a variety used in "ethnically encumbered or traditional pursuits"; another H (American English in the case of the Old Order Amish and Canadian English in the case of Mennonites) to be a variety used in "ethnically unencumbered or modern pursuits"; and the $L$ (Pennsylvania German in the case of Old Order Amish or Plaurdietsch in the case of 


\section{FISHMAN'S TYPES OF DIGLOSSIA}

\section{Four Types of Diglossia}

(a) $H$ as classical, $L$ as vernacular

Relationship between $\mathrm{H}$ and $\mathrm{L}$ :

The two varieties are genetically related.

Cases:

Classical \& vernacular Arabic

Classical \& Classicized Greek

Classical \& vernacular Tamil

Classical \& vernacular Sinhalese

Latin \& French among francophone scholars \& clergy

Sanskrit \& Hindi

Classical Mandarin \& Modern Pekinese

(b) $H$ as classical, $L$ as vernacular

Relationship between $\mathrm{H}$ and $\mathrm{L}$ :

$$
\text { Case: }
$$

The two varieties are genetically unrelated.

Loshn koydesh \& Yiddish

(c) $H$ as written/formal-spoken, $L$ as vernacular

Relationship between $\mathrm{H}$ and L:

The two varieties are genetically unrelated. Cases:

Spanish \& Guarani in Paraguay

English (or French) \& vernaculars in colonies

(d) $H$ as written/formal-spoken, $L$ as vermacular

Relationship between $\mathrm{H}$ and $\mathrm{L}$ :

The two varieties are genetically related. Cases:

High German \& Swiss German

Pekinese \& Cantonese

Standard English \& Caribbean Creole

Figure 6. Fishman's types of diglossia. Fishman identifies four types of diglossia, H-L relationships, and cases. Source: Fishman (1980, pp. 4-5). 
Mennonites) to be the variety used every day in pursuit of family, home, and simple economies (Fishman, 1980, p. 4).

Given these types and varieties of diglossia, Fishman reconceptualized his pioneering extension of societal diglossia with individual bilingualism first as an interactive model of diglossia and bilingualism then as an interactive model of biculturalism and di-ethnia.

\section{An Interactive Model of Diglossia and Bilingualism}

Fishman $(1967,1980)$ defined diglossia as a social phenomenon or arrangement maintained intergenerationally by social and linguistic compartmentalization and bilingualism as an individual phenomenon maintained as an "individual asset or debit." Fishman viewed the two not as "a-s-or-none" phenomena, but as continuous variables that interact systematically in a "field" (Bales, 1950). To explain the interactive relationship simply, though, Fishman dichotomized diglossia and bilingualism as if he observed them to be strictly compartmentalized. Thus he explained the complex process of interaction and change and raised important issues of maintenance and shift, and in some cases of revival. Figure 7 illustrates his interactive model of bilingualism and diglossia in a four-fold schema of (1) both diglossia and bilingualism, (2) diglossia without bilingualism, (3) bilingualism without diglossia (transitional), and (4) neither diglossia nor bilingualism (or monolingualism).

Both Bilingualism and Diglossia (Cell A). The idealized view of a speech community with both bilingualism and diglossia is one in whicl: nearly everyone knows both $\mathrm{H}$ and $\mathrm{L}$, and the pattern of distribution resembles stable diglossia. In Paraguay, for example, more than half the population speaks both Spanish (H) and Guarani (L) (Rubin, 1968); in the region of the Swiss German, the entire school-age and adult population alternates between Standard German (H) and Swiss German (L) (Ferguson, 1959); and in an area of Montreal, communities of different origins interact in English (H) and French (L) (Hughes, 1970). In speech communities such as these, compartmentalization occurs at various levels of social life ranging from 


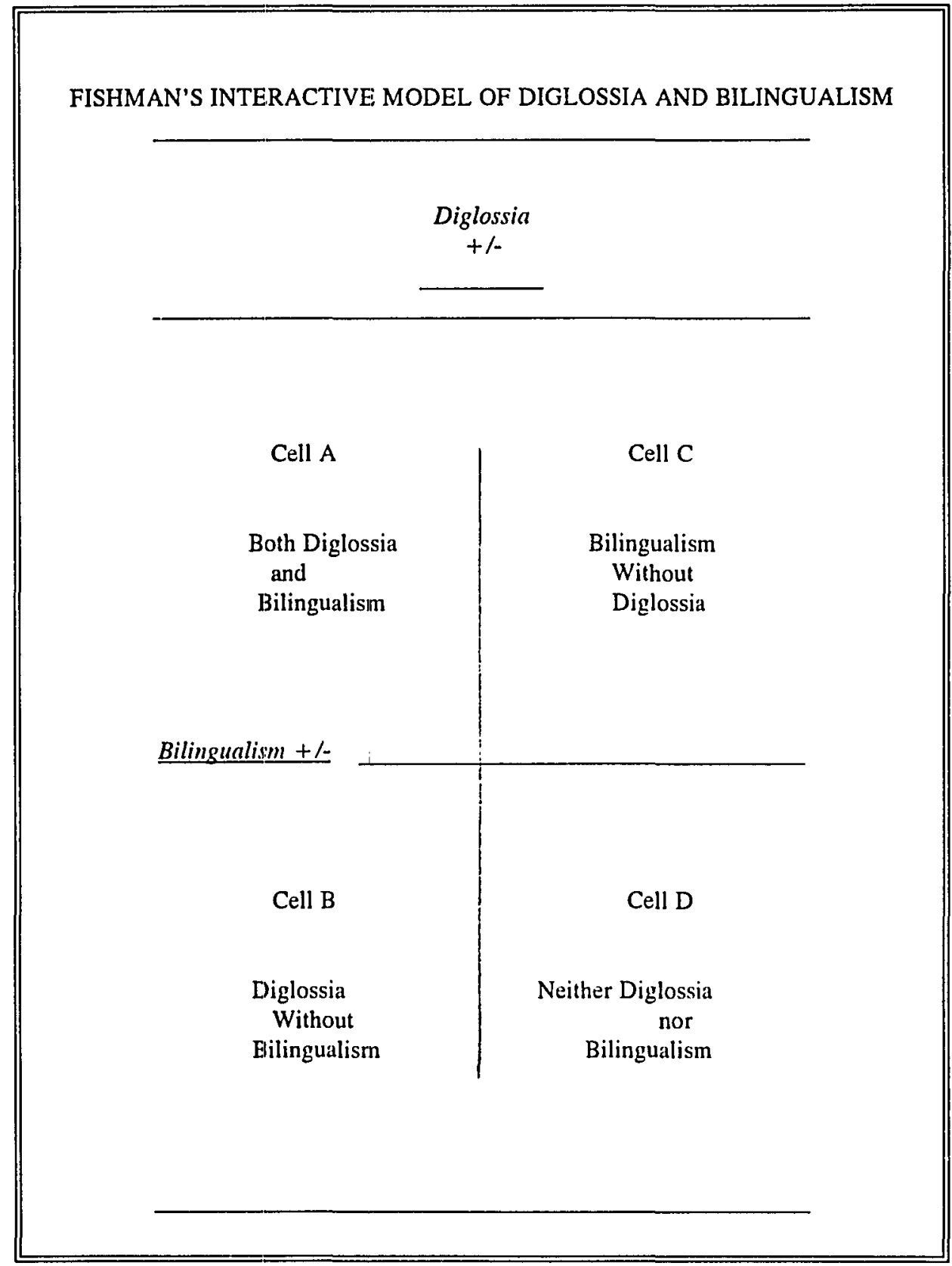

Figure 7. Fishman's interactive model of diglossia and bilingualism.

Fishman's interactive model of societal diglossia and individual bilingualism is illustrated as a fourfold schema: Cell $\mathrm{A}$, both diglossia and bilingualism; Cell B, diglossia without bilingualism; Cell C, bilingualism without diglossia; and Cell D, neither bilingualism nor diglossia. Source: Fishman (1980, p. 6). 
worldwide and nationwide societies through ethnic communities to individuals in social networks. Membership in the society, community, or network is based on knowledge of the "correct" language in the appropriate social context, access to legitimate and complementary social roles via linguistic repertoires, and entry to institutions of language/literacy learning. The studies illustrate several important points about diglossia: one, that a diglossic community, whether large or small (i.e. Paraguay or a Montreal neighborhood), may be complex; two, that linguistically unrelated languages (i.e. Spanish, an Indo-European language, and Guarani, an indigenous American language) may exist in a diglossic relationship; and three, that a school system in the modern world may be instrumental in maintaining diglossia (i.e. Swiss German schools) (Fishman, 1967, 1971, 1980).

Diglossia Without Bilingualism (Cell B). The model of diglossia without bilingualism may occur when two or more groups unite within one political, religious, and/or economic entity. Leaders, the "insiders," speak only the $\mathrm{H}$ language; and the others, the "outsiders" and often a larger group, speak only the $L$. Examples of this situation may be found in the past, in czarist Russia, colonial Asia, and colonial Africa, when fashionable nobles spoke Northern European languages $(\mathrm{H})$ and the masses spoke vernaculars (L). Cases also exist currently, among urbanized African groups, Hindu castes, and French-Canadians whose access to roles via linguistic repertoires is minimal or nonexistent except through interpreters or through the use of a pidgin (Fishman, 1967, 1971, 1980).

Bilingualism Without Diglossia (Cell C). A speech community with bilingualism and without diglossia is one in which members speak two or more languages and do not restrict the use of one language to one set of circumstances or purposes. During periods of immigration, colonization, and industrialization, a modern speech community and its government, church, and school may absorb or dislocate members of the traditional speech community. Instead of "two carefully separated languages each under the eye of caretaker groups of teachers, preachers 
and writers" (Fishman, 1967, p. 36), a new pattern of language mixing and switching becomes the mother tongue (and only tongue) of the new generation. The circumstances may lead either to diminished compartmentalization, fluid roles and relationships, and communicative interaction, on one hand, or to an elaborated version of the traditional situation before immigration, colonialization, or industrialization, on the other. Thus, bilingualism without diglossia is a "leaky" variety, "extremely unstable and transitional" that results from rapid and massive changes in diglossic relationships that leads to displacement or replacement of either the H, the L, or both (Fishman, 1967, 1971, 1980).

Neither Bilingualism Nor Diglossia (Cell D). The pattern of neither bilingualism nor diglossia, but monolingual, presumes a speech community to be small, isolated, and undifferentiated, both linguistically and socially. A few speech communities resemble this characterization. But, no speech community is completely homogeneous or completely monolingual. The presence of changing patterns of speech in work, religion, and education lead to changing patterns of talk and writing; additionally the absence of traditional compartmentalization in instructional settings may lead to a mixing and shifting of different regional dialects. This phenomenon may be found in speech networks (Fishman, 1967, 1971, 1980; Milroy, 1980, 1986).

\section{An Interactive Model of Biculturalism and Di-ethnia}

Fishman's (1967) interactive model of diglossia and bilingualism led him, similarly, to the interactive concept of individual biculturalism and societal di-ethnia mentioned earlier (Fishman, 1980). He defined biculturalism as an "individual asset or debit" like bilingualism that corresponded to no particular societal or inter-generational arrangenent and di-ethnia as a societal arrangement like diglossia that ethno-societies maintained intergenerationally by means of social compartmentalization. He tentatively suggested a four-fold model of interactive 
biculturalism and di-ethnia and qualified it as "weakly related" (Fishman, 1980, pp. 10-13).

Thus, he said:

Not only can we find bilingualism with and without diglossia (cells 1 and 2), as well as diglossia with and without bilingualism (cells 1 and 3 ), but we can also find (a) multiculturalism with and without di-ethnia, as well as (b) diethnia with and without either bilingualism or diglossia. As we note, multiculturalism and di-ethnia do not form a four-fold table . . . as do bilingualism and diglossia (Fishman, 1980, p. 11).

Still tentative, Fishman suggested di-ethnia to be a rare phenomenon. When di-ethnia exists beyond the "three generation cut-off" as it does among the Old Order Amish

(Mennonites), Hasidim, African-Americans, and the Aboriginals on American shores, and among Moslems, Japanese, Chinese, and non-Russophone Soviets elsewhere, it is "rarer . . . than diglossia and far, far rarer . . . than biculturalism":

Di-ethnia . . . is found beyond the three generation cut-off in the . . . world where traditional behaviors, dress, diet and values dominate most of life but where modern econo-technical roles require different dress, diet and languages and do so not only for intergroup interactions but for intragroup interactions within this arena as well. Similar compartmentalization is encountered beyond the three generation cut-off . . . among stable populations living at longestablished political borders and sharing market days and other limited collective experiences (e.g. sports contexts). Finally, and even more exceptionally, di-ethnia is still encountered at times even after language shift has eroded bilingualism and diglossia to the vanishing point. Thus, even with the transethnification of Blacks and aborigines, a deep-seated and often conflicted di-ethnia at times reveals itself (Fishman, 1980, p. 13).

For Fishman $(1966,1967,1980)$, the concepts of diglossia, bilingualism, biculturalism, and diethnia revealed a complex "field" of ethnolinguistic interaction and change and in some cases an ethnolinguistic revival (Fishman, 1985). The complex interactive relationship between sidestream ethnicity and language and mainstream ethnicity and language and related concepts of individual bilingualism and biculturalism, and societal diglossia and di-ethnia, is illustrated in figure 8. 


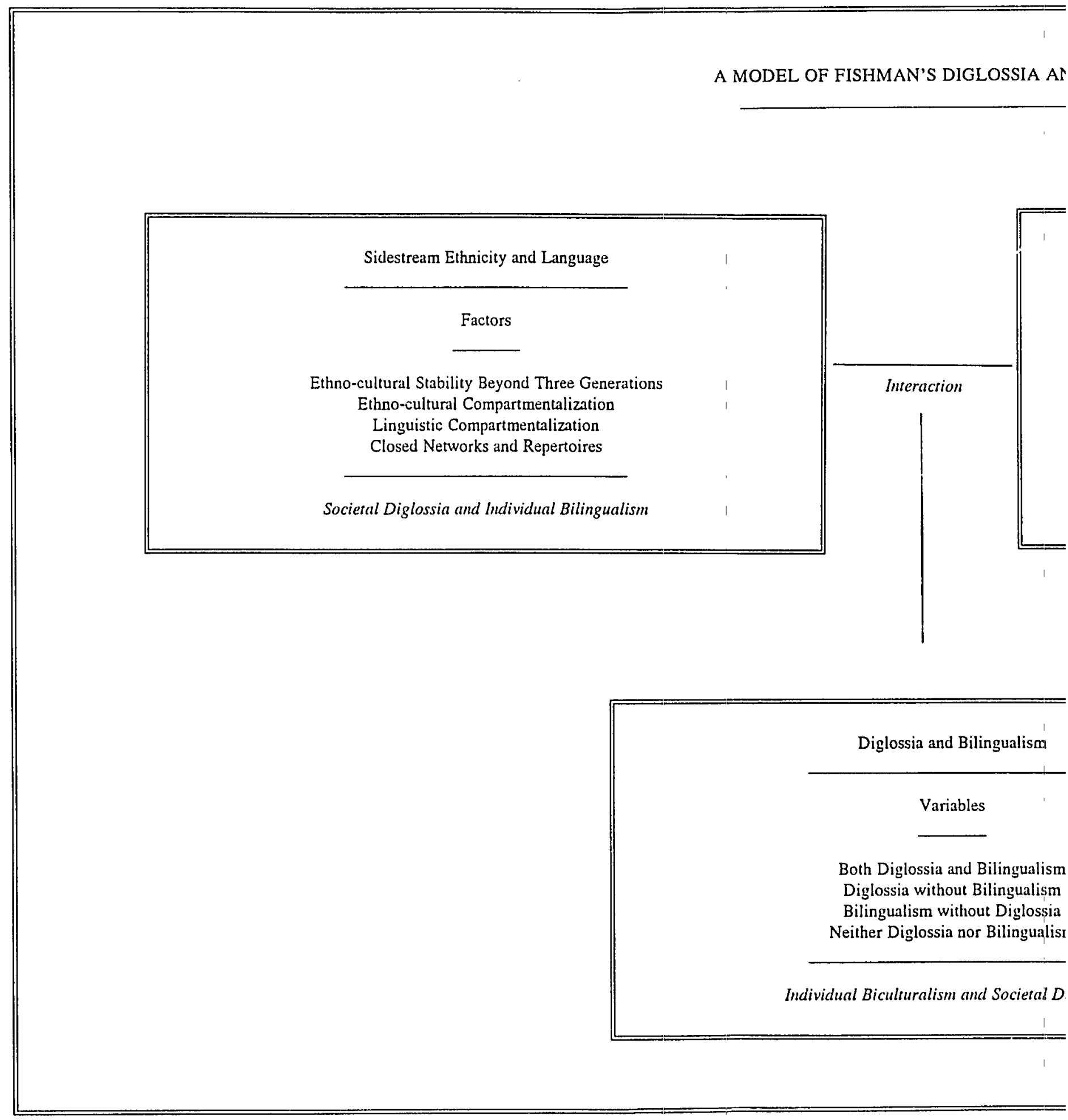

Figure 8. A model of Fishman's diglossia and b 

The Issues of Maintenance, Shift, and Revival

Fishman's studies of language and culture generally and of language and ethnicity specifically gave him a good vantage point for examining the cross-cultural and cross-linguistic experience of sidestream ethnicity in mainstream educational settings. First, concerning the terms culture and ethnicity, he said:

Culture is a much broader designation than ethnicity, particularly in connection with modern complex societies. It deals with norms pertaining to all of human behavior, belief, and valuation. Ethnicity is a narrower concept, particularly in modern times,. It focuses on "peopleness relatedness", that is: on those cultural behaviors, values and beliefs that are related to "peopleness authenticity", i.e. to membership in a particular people and its defining tradition (Fishman, 1980, p. 10).

Second, concerning the relationship between language and ethnicity in education, a

field that brought him to the very heart of sensitive issues of inter-generational continuity, conflict, and compartmentalization, Fishman said language itself is an inevitable part of ethnoculture, an index of ethnoculture with which it is associated, and a symbol of the ethnoculture with which it is joined (Fishman, 1989, pp. 83-85):

Language is . . part of culture .. A All those who seek to enter fully into a given ethnoculture and understand it must, accordingly master its language . . . On the other hand, language shift, or loss of a culture's intimately associated language, is indicative of far-going culture change, at the very least, and possibly, of cultural dislocation and destruction . . . L Language as an index of culture is a by-product . . . of culture. Languages reveal the ways of thinking ... Languages provide lexical terms for . . . artifacts, concerns values and behaviors recognized by their associated ethnocultures . . . . Language is an elaborate symbol system of humankind . . . Language . . . "stands for" or evokes . . . culture (Fishman, 1985, pp. xi-xii).

Third, concerning the process of interaction and change, the issues of maintenance and shift, Fishman found comparmentalization to be the crucial factor contributing to stable diglossia and fluidity to be the critical factor contributing to unstable diglossia, transitional bilingualism, and eventual monolingualism (Fishman, 1967, 1980). In stable diglossic situations, he added, for example, speech communities maintained social compartmentalization and linguistic compartmentalization through membership in closed nerworks where participants 
established "strict . . . boundaries" between the societal functions" of traditional and modern life and enforced the associated use of $\mathrm{H}$ and $\mathrm{L}$ varieties of language, respectively. In leaky diglossic situations, however, speech communities developed fluid social and linguistic relationships through membership in open networks in which members participated in "'public familiarity' between strangers and semistrangers . . . nonstatus-stressing interaction . . . and rationalization of the work [school] sphere" (Fishman, 1980, p. 5). The closed-network situation, he continued, accounted for the separation between sacred and secular in ethnic life as well as the separation between indigenous and foreign, traditional and modern, elite and mass in cultural life. And the open-network situation accounted for "blurred" relationships between ethnic life and modern life (Fishman, 1980, p. 5). Milroy $(1980,1986)$ complemented this description of open and closed networks with a description of "uniplex" and "multiplex" networks together with concepts of "zones . . exchanges . . rights . . . and obligations" of network membership (Milroy, 1980, 1986).

Finally, in relation to the issues of maintenance and shiff, Fishman raised a third issue, the issue of the revival of sidestream ethnicity amid mainstream ethnicity. Fishman observed evidence of an ethnic revival among immigrant minorities and indigenous minorities in the United States, Canada, and parts of Europe. The principles governing the implementation of ethnic revivals, he added, were both micro-determined and macro-determined. At the microlevel, he observed evidence of ethnic revivals in scenes from ethnic life, in the ethno-acts and ethno-events of sidestream ethnicity involving certain persons, certain places and their congruent topics and role relationships, the very building blocks of ethnic-situations. At the macro-level, he found entire slices of ethnic life implemented in "religion more than work, home/family more than street/neighborhood, school more than entertainment" (Fishman, 1985, p. 503). He characterized sidestream ethnicity as something distinct from "all or nothing." Instead, he advanced a notion of "ethnicity repertoire" which got to the sidestream contextual issues of 
what language with whom, when, and why. He found the critical factors of ethnicity repertoire

to be repertoire compartmentalization and repertoire range in networks (Fishman, 1985):

Immigrant-derived ethnicity [in North America] . . . and indigenous minority ethnicity in many settings throughout the world . . . implemented as it largely is in a context characterized by interethnic contact . . . is largely a reportorial phenomenon. By this I mean it coexists together with a number of "varieties" of socially-patterned behaviors, some of which are sidestream ethnicityderived, others of which are mainstream ethnicity-derived . . . the first and second generational pangs of conflict and double marginality . . . are still present . . . but they are much more muted and mellow . . . The spirit of the times is different . . . Mainstream ethnicity . . . is criss-crossed by sidestream ethnicity-associated ways of doing, feeling and knowing . . . [and sidestream ethnicity] is criss-crossed by mainstream doings, feelings and knowings. The total repertoire is increasingly experienced as a highly integrated whole (rather than as bits and tatters of disparate cloth), although it is made up, as are all modern cultures, of old and new threads of diverse ages and origins. It is the totality of these threads which constitute the total repertoire, but they are never implemented totally, all at the same time. As with repertoires more generally, the ethnic repertoire is selectively (i.e. contextually) implemented, on the basis of socioconsensual principles of appropriateness and in pursuit of individual goals within a framework of social norms and expectations. Identity is a matter of social location . . . Particular combinations of threads ("varieties" . . .) are selectively implemented, sometimes combining sidestream and mainstream ethnicity, and sometimes combining old (arguably "authentic") and new aspects of either or both. Old bread and new wine are constantly brought together, and as a result, newness is less overwhelming and disorienting. The principles of selection between the myriad of possible combinations are both macro- and micro-determined (Fishman, 1985, pp. 502-503).

Fishman concluded that in contexts where sidestream ethnicity and mainstream ethnicity

were jointly permissible, compartmentalization diminished and the blending of ethnicities

proceeded rapidly. On the other hand, in situations allocated to either one ethnicity or another,

the two could be kept studiously apart.

The compartmentalization of dual ethnicity is generally difficult to maintain in modern, interactive urban contexts. As a result, not only does di-ethnia seldom obtain at the societal level, but ethnic discontinuity also becomes rare (Fishman, 1985, p. 505).

Language is . . part of, indexical of, and symbolic of ethnocultural behavior. As ethnicities meld, change, or absorb and replace one another, it is inevitable that the languages of these ethnicities will be modified as well . . . (p. 505) . . .. the ethnic revival . . . that occurred ... generally related to increased institutional concern for language and increased retrospective mother-tongue acquisition . . . Some traditional communities . . . proved capable . . of 
language maintenance via boundary maintenance (Fishman, 1985, pp. 507508).

Fishman called for continued study of ethnic revivals saying that any theory of an ethnic revival in Anglo-America must take into account its co-occurance, during the sixties and seventies, with both indigenous and immigrant revivals in many parts of North America and Western Europe (not to overlook recent ethnic revivals in Eastern Europe and Asia) (Fishman, 1985, pp. 490-525). Among those to share Fishman's concern for ethnolinguistic heritage was Del Hymes who spoke of the problem of "old dichotomies . . . [between] mutually exclusive opposites" and the need for "balance . . . between modes of use of language . . . . mutually indispensable functions" (Hymes, 1986, p. 148).

\section{ETHNOGRAPHY AS "COMMUNITY SCIENCE: HYMES' (1961) SPEECH ACT ON "THE ETHNOGRAPHY OF SPEAKING"}

First and foremost, a humanist, Del Hymes championed a "multilingual, multicultural world in which 'little peoples' and 'little languages' would not only be respected but valued" (Fishman, 1982, p. 5). A participant-observer of ways of speaking and ways of knowing in many sectors of life, education, national development, cross-cultural communication (Hymes, 1986, p. 38), he held fast to the holistic perspective of ethnography at a time when social scientists generally rejected descriptive research in favor of experimental research.

For three decades, Hymes advocated interdisciplinary partnerships. One such partnership among language, anthropology, and education gave rise to the field educational linguistics (Hymes, 1961, 1980; Spolsky, 1978; Stubbs, 1985, 1986) in the past decade:

Of "educational linguistics" . . . the fundamental point is sound and essential. We need to be able to think of language situations and educational situations as part of the evolution of human societies ... We need to think of languages and personal competencies as specific sets of communicative means, shaped by particular histories and adaptive niches. We need to transcend the liberal assumption built into so much of linguistic thought, that all sets of communicative means are equal in the eyes of linguistic theory. They are not equal in the eyes of history. 
We inhabit a world whose languages are stratified in terms of roles . . as world, national, and local . . . for example English, Danish, Frisian ... It remains that English, as the name for a set of lexical and discourse resources, and a body of materials employing them, has a different scale.

With regard to persons [whose command of English is limited] . . . we must be vigilant against false stereotypes and ascription of deficit . . . The truth is social life shapes communicative competence and does so from infancy onward. Depending on gender, family, community, and religion, children are raised in terms of one configuration of the use and meaning of language rather than another. The particular configuration will affect the opportunities and access they have for other uses and meanings of language. Depending on social, economic, political factors, they will come to be able to use and experience language in some ways and not in others. Often enough, the result will be less than justice or vision would require (Hymes, 1980, pp. v-vi).

For his contributions to community science, to the convergence of language,

anthropology, sociology, psychology, and education in ethnography, his colleagues Ferguson and Fishman dubbed him "a leading light" among "a few courageous stalwarts" (Fishman, 1982, p. 5).

\section{Problems of "One Language" Aititudes, Policies, and Goals in Schools}

Hymes' was among the first to link problems of literacy, language development, and language assessment in multilingual, multicultural societies to prevailing "One People, One Language, One School" attitudes, policies, and goals in official systems of education. His earliest studies of Otomi, Zapotec, and Funio languages in official Spanish schools in Latin America, and of Kaska, Hopi, and Navaho languages in official English schools in North America, led him to say to an audience of educators that ways of knowing and "ways of learning a language" are "not the same from society to society, or from group to group in societies as our own" (Hymes, 1961, pp. 2-16).

Early in the 1960s, Hymes offered a solution to the problem of one language policies and practices in diverse speech communities. He spoke of a partnership between anthropology and education to address the advantages and disadvantages of language education policies and 
practices on language development and assessment. What he proposed, then, was an approach

to bilingual education that was not transitional in attitude, policy, and goal:

It is possible to design materials for teaching of one language specifically for speakers of another, and to anticipate the particular advantages and disadvantages their own system will confer on the task. This suggests the contribution that anthropology can make to such problems in education . . . . Such a science would . . . make it possible to predict or at least anticipate more effectively the interference which a program of literacy, bilingual education, and so forth would encounter . . . . It is remarkable that no such comparative study of speech function exists (Hymes, 1961, pp. 7-8).

Such designs of bilingual programs, he said, could have long-term benefits to the role of

language in modern society, benefits best assessed not by test scores but by case-history accounts

that show the benefits to children, to communities and their schools (Hymes, 1980, pp. 142-

146).

Hymes continued to voice these concerns in the 1980 s. Speaking to another generation of educators of the present-day threat of the proposed English-only language amendment to the United States Constitution (Daniels, 1989; Fishman, 1989; Gonzalez, Schott, \& Vasquez, 1988; Marshall, 1986; Stalker, 1988; Sundherg, 1988) to bilingual education and to the situations of African-, Asian-, European-, Hispanic-, and Native-Americans in Anglo-American classrooms, Hymes called for a renewed link between language research and educational research. Research of "the role of language in human life," he said, "has been inadequate" (Hymes, 1980, p. 139). Hymes remained committed, then, to solving scientific and practical problems associated with proposed changes to the way linguists understand language development and what educators do with language development in schools:

The ability of schools to deal with the linguistic situation [of ethnic heritage and uses of language] in the United States [and Canada] is severely limited. One often says start where the child is, develop the child's full potential. To do that, linguistically, one must have knowledge of ways of speaking in the community of which the child is a part. Very little knowledge of this sort is available. 
If we are to know . . what speaking is like, there must be ethnographies of speaking, open to discovery of facts that are inconvenient for one's grammar, pedagogy, or social assumptions (Hymes, 1980, pp. 139-140).

He remained committed to the ethnography of speaking, a concept, a mode, an "imperative"

$(1961,1972,1980,1986)$.

\section{The Ethnography of Speaking: An Interdisciplinary Concept}

Hymes viewed the ethnography of speaking as an interdisciplinary research concept and a descriptive mode. He distinguished between "ethnography" and "field work" by saying that "field work" was a term used loosely at times for coming in contact with people as sources of information and that not all field work was ethnography. He further restricted "ethnography" to connote "inquiry that is open to questions and answers not foreseen . . . not precoded." "Ethnography," he added, amounted to "steering" between the poles of an "I was there" approach and a "pre-coded set of alternative responses" approach; to "being attentive and smart; " to knowing when not to rule out "sensitive awareness, empathy, and intuition;" recognizing when to call upon pre-existing models and frameworks; and to "being able to get beyond them" (Hymes, 1980, pp. 73-74).

Ethnography, then, is a matter of "feedback, of "dialectal interplay":

In a word, ethnography is inquiry that begins with recognition that one is at work in situations that are indeed, massively prestructured, but prestructured by the history and ways of those among whom one inquires (Hymes, 1980, p. 74).

Concerning himself, then, with "multiple levels" (Bales, 1979) of interaction, Hymes said the goal of sociolinguistic inquiry is to describe "a language, the social relations, or culture of a community" at the levels of the individual, the group, the community, the nation-state, and indeed, the "emerging world society" (Hymes, 1986, p. 53):

Such a goal is of concern to practical work as well as to scientific theory. In a study of bilingual education, e.g., certain components of speaking will be taken into account, and the choice will presuppose a model, implicit if not explicit, of the interaction of language and social life. The significance attached to what is found will depend on understanding what is possible, what 
universal, what rare, what linked, in comparative perspective. What ... researchers need to know linguistically about a community, in selecting a language variety, and in conducting interviews, is in effect an application of the community's sociolinguistic description. In turn, practical work, if undertaken with its relevance to theory in mind, can make a contribution, for it must deal with the interaction of language and social life, and so provides a testing ground and source of new insight (Hymes, 1980, pp. 52-53).

Hymes' coined "some initial heuristic schema" needed for systematic and adequate description. Essential concepts, he said, included a notion of community and its scales of speech community, speech field, speech network, and speech situation; a notion of speech situation and its scales of speech event, speech act; and components of speech and its mnemonic code of SPEAKING (Hymes, 1986, pp. 52-53).

\section{The Ethnography of Speaking: Some Initial Heuristic Schema}

Hymes characterized a speech community as a specific set of linkages among individuals, language, and speech rules and place or situation governing language and linguistic variation. He defined speech community itself as a community sharing rules for the conduct and interpretation of speech, and rules for the interpretation of at least one linguistic variety ${ }^{n}$ ( $p$.

54). Woven into that notion of speech community were scale units of analysis including speech

field (akin to the notion of social field)" (p. 55), defined as the total range a person's speech knowledge or repertoire, and speech network, defined as a system of linkages based on shared language and shared rules for speaking. Hymes adopted the following definitions:

The term speech community . . postulates the basis of description as a social, rather than a linguistic, entity .... A speech community is defined as a community sharing both rules for the conduct and interpretation of acts of speech, and rules for the interpretation of at least one common linguistic code . ... The speech field (akin to the notion of social field) can be defined as the total range of communities within which a person's knowledge of code and speaking rules enables him to move. Within the speech field must be distinguished the speech network, the specific linkages of persons through code and speech rules across communities (Hymes, 1967, p. 18).

Similarly, Hymes presented situational and contextual notions of a speech evemt, defined as a sequence of "speech acts," and speech act represented mnemonically as SPEAKING, a code for 
"components of speech acts": "setting . . . participant . . . end . . . act sequence . . key . . . instrumentality ... norm . . . and genre" (Hymes, 1974, 1980).

Setting (S). The component termed "setting and scene" makes up the "situation" of the speech act. Setting refers to the time and place and to the general physical circumstances of the act while scene gives "cultural definition" or provides a "psychological definition" of the occasion. Setting is concrete and somewhat static while scene is kinetic and may shift within one setting, as from "formal to informal" or "serious to festive." Speech acts can thus be used to define scenes and may be judged as appropriate or inappropriate in relation to scenes. Similarly, scenes may define acts and may be judged appropriate or inappropriate in relation to settings. So setting and scene may be linked as components of the act situation (Hymes, 1986, p. 60).

Participant (P). The component called "participant" related to the roies and relationships between and among speakers. A participant generally fulfills a socially specified role determined by such factors as gender, age, education, occupation, and identity. Additionally a participant generally interacts in a relationship characterized as a triad, defined as a combination of three roles, a speaker (sender), a listener (receiver), and an observer (audience); a dyad, defined as a combination of two roles, a speaker and a listener; or a monad, defined as a speaker who participates in solo or aside with indifference to relationship. In each case, "participant" is a universal component of a speech act. Competence requires knowing the conventions of the triadic model of roles and relationship, the dyadic model of roles and relationship, and the monodic model of a participant role (Hymes, 1986, pp. 58-61).

End (E). "End" refers to the conventionally expected purpose or outcome of a speech act or speech event. The purpose of the event from the standpoint of a speech community need not be identical to the goal of the participants. An event in a schoolroom has a recognizable social end in view, but the various participants, for example, the superintendent, the principal, 
the teacher, the student, and parents have different personal goals. The rules vary accordingly (Hymes, 1986, pp. 61-62).

Act Sequence (A). "Act sequence" deals with message form and message content, "how things are said" and "what is said." Both factors are central to the "syntactic structure" of the speech act; both are tightly interdependent; and both are key to the scientific and humanistic study of "ways of speaking." Concerning message form, rules govern, condition, and at limes control the inner logic of what is said. With respect to message content, rules govern matters of "topic and change of topic." Competence, the ability of the speaker to deal "how things are said" and "what is said," requires (a) understanding "what is being talked about . . . when what is being talked about has changed," (b) managing talk about the topic, and (c) changing talk about the topic. At the same time, competence requires a personal mastery and autonomous freedom that go beyond an explicit statement of rules and features of message form and message content. The more a "way of speaking" is shared by a group, the more meaningful it becomes within a group, indeed, the more important it is to scientific and humanistic inquiry of human expression (Hymes, 1986, pp. 59-60).

Key (K). The component "key" refers to the tone manner, or spirit in which an act is performed and the message is conveyed. Competence involves knowing not only "what" should happen next but also "how" it should happen. When "what" a speaker says does not match the "key ... register . . . or style" the speaker is using, listeners are likely to pay more attention to the key than to the content, for example, to the burlesque of ritual rather than to the ritual itself (Hymes, 1986, p. 62; Wardhaugh, 1986, p. 240).

Instrumentality (I). The component called instrumentality is understood to mean (a) speech code or form of speech and (b) speech channel. The speech code or choices of speech codes may be indicative of the history of language resources in the community; the presence, or absence, of mutual intelligibility among speakers; and specialization of use or function. The 
speech channel is understood to indicate choice of oral, written, telegraphic, semaphore, or other medium of transmission of speech. Competence in the instrumentalities in a speech community requires developing a repertoire of codes, knowing when to switch codes, and sensing how to, and how not to, mix codes (Hymes, 1986, pp. 62-63).

Norms of Interaction and Interpretation (N). Two factors, the norms of interaction and the norms of interpretation, may be grouped together as "norms." The norms of interaction govern speakers' interaction in speech acts. Knowing when to take turns at talk, for example; or recognizing when to sing, pray, recite, or whisper in a church service; and laughing when the boss tells a joke involve norms of social interaction. The norms of interpretation govern the meaning speakers give to loudness, silence, eye contact, closeness, and distance. Competence in the norms of interaction requires knowing, using, and applying the interactional rules of social structure and social relationships agreed upon by the community. Competence in the norms of interpretation requires knowing, using, and applying the meaning of myth, legend, or lore in cultural beliefs, customs, adhered to by the community. While there is overlap between the rules of interaction and the rules of interpretation, the former implicates proprieties of a social system and the latter implicates proprieties of a cultural system (Hymes, 1986, p. 64).

Genre (G). The speech act itself may be viewed as an instance of "story" or "genre." For all speech acts, poems, myths, tales, proverbs, riddles, curses, prayers, lectures, ads, letters, even dissertations and dissertation defenses, may be characterized as stories or genres. Various formulas "mark" the ways in which one genre differs from another (Hymes, 1986, p. 65). These formulas make up the linsey-woolsey of ethnography (not to mention the chantilly of English belles-lettres).

The Ethmography of Speaking: Imperatives for Change

Hymes recognized language to be "a subject beset by prejudice and preformed opinion." He adopted the paradigm of the "human sciences, " revived the tradition of 
ethnography, and conceived of the ethnography of speaking, illustrated in figure 9 . He challenged those concerned with literacy, language development, and language assessment to "step back, imaginatively, in a way amalogous to "zero-budgeting" -- to ask "What if ... ?" (Hymes, 1980, p. 71). What if educators were to "start where the child is . . linguistically . . - [to] develop the child's full potential"? What if classrooms in multilingual, multicultural settings were to become natural places for ways of speaking, ways of knowing, and ways of learning? What if educational leaders were to become a major force in addressing the complex problems of language acquisition, development, and assessment in curriculum and instruction, special education, and counseling? What if policy-makers were to validate the use of minority mother tongue and majority mother tongue in education as "a fundamental human right"?

(Spolsky, 1986, p. 14). What if concerned policy-makers, superintendents, principals, teachers, and parents involved themselves with concerned linguists and educational researchers, all adopting certain imperatives and certain goals?

First, to see the need for knowledge of language situations in our country [and our communities].

Second, to support training and research to obtain such knowledge.

Third, to change the relations between linguistics and education.

Certain goals on which we would probably agree should govern imperatives for change. The treatment of language in schools should help, not harm. It should help children, and through them their families and communities, to maintain and foster self-respect. It should be consonant with respect for diversity of background and aspirations. It should contribute to equality rather than inequality (Hymes, 1980, pp. 140-141).

While some mainstream policy-makers, educators, and linguists misconceive these goals and imperatives for change as "nationalism or . . chauvinist tribalism" (Fishman, 1985b, pp. 490-501), this concern for ethnic heritage and language as "nostalgia and sentimentality" (Hymes, 1980, p. 146), this interest in a Mennonite speech community as "particularistic and limiting" (Hymes, 1980, p. 146), I a'ssert that these goals, imperatives, concerns, and interests are central to the role of language in school and community today: 


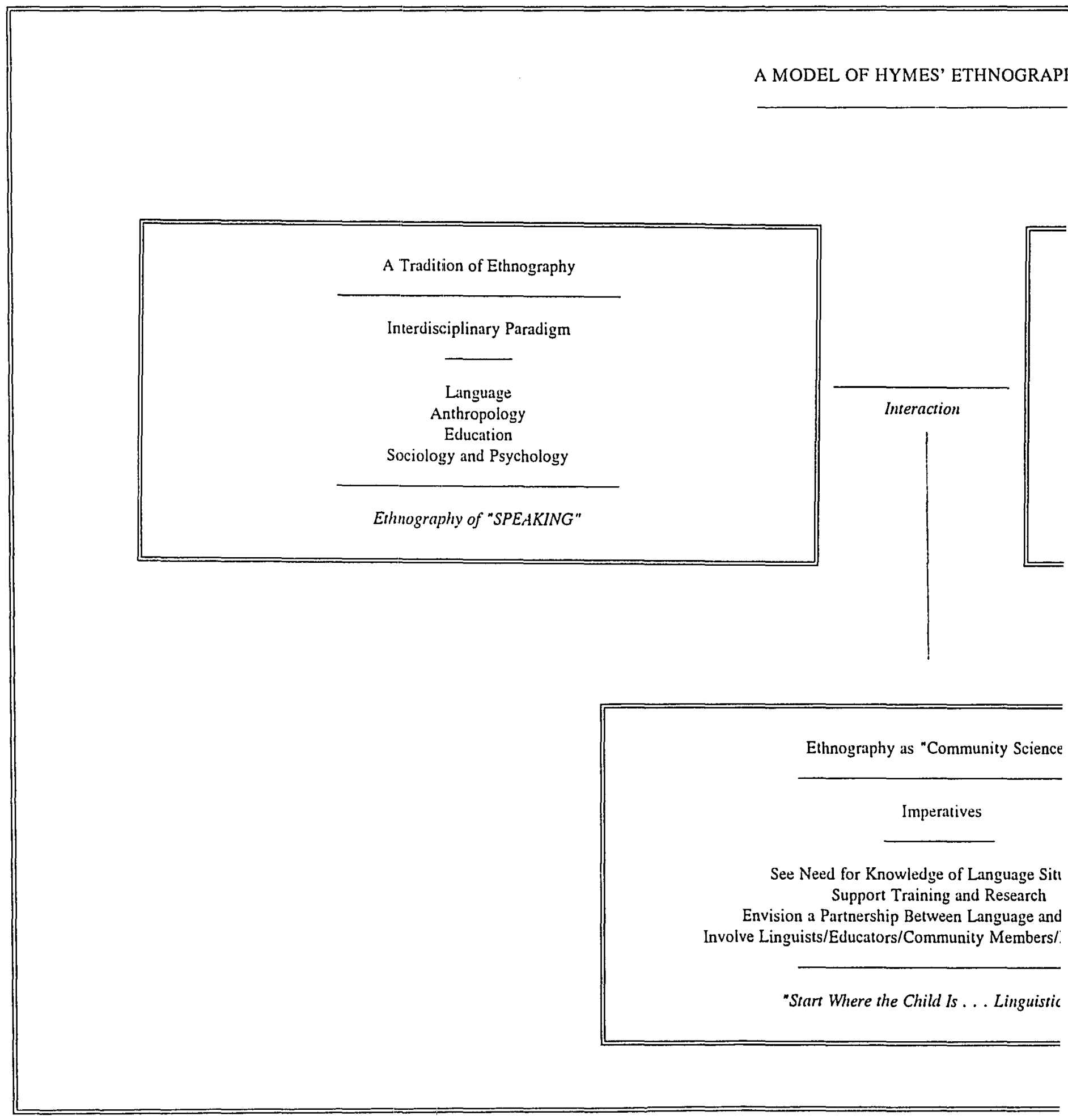

Figure 9. A model of Hymes' ethnography of 



\section{IODEL OF HYMES' ETHNOGRAPHY OF SPEAKING}

\begin{tabular}{|c|c|}
\hline & Ethnography of Speaking \\
\hline & Factors \\
\hline \multirow[t]{2}{*}{ Interaction } & $\begin{array}{c}\text { Speech Community } \\
\text { Speech Network and Speech Repertoire } \\
\text { Speech Event and Speech Act } \\
\text { Setting/Participant } / \text { End } / \text { Act } / \text { Key } / \text { Instrumentality } / \text { Norm } / \text { Genre }\end{array}$ \\
\hline & Components of "SPEAKING" \\
\hline
\end{tabular}

Ethnography as "Community Science"

Imperatives

See Need for Knowledge of Language Situations Support Training and Research

vision a Partnership Between Language and Education Linguists/Educators/Community Members/Parents/Children

"Start Where the Child Is . . Linguistically"

9. A model of Hymes' ethnography of speaking. 

This . . revival of concern with ethnic heritage and uses of language is not merely a part of the annual tourist laundry ring around the world, each countryside emptying out in summer to take in someone else's carefully staged culture while on vacation. It is a shift in outlook that has to do with what one is for oneself, as a member of a family with a certain name, a certain history, a knowledge of certain places, certain ways of meeting sorrow and sharing joy. Many ... know the price that can be exacted in acquiring a lingual franca at the cost of a language of the home.

Some repudiate concern of this kind as nostalgia and sentimentality, even a dangerous refusal to face present realities. I think that something profound is involved. Any one concern may seem particularistic and limiting; when all such concerns are considered together, one sees something general, a deeprunning tide. It is a vision limited to a national lingua franca that begins to appear old-fashioned, limited, sectarian (Hymes, 1980, p. 146, italics mine).

So, to approach educational situations and language situations of African-, Asian, Hispanic-,

Native-, and European-Americans, and further, to approach situations renewed by immigration, with one-language attitudes, policies, and goals, without a revival of concern for ethnic heritage and uses of language, does indeed seem "old-fashioned, limited, and sectarian." Such an approach to diversity seems in need of assessment.

Moving now from ethnography as community science in Chapter II, toward an ethnography of speaking in a Mennonite speech community in Chapter III, I return to concepts and methods derived from this interdisciplinary framework. I adopt the Hymes-type work in ethnographies of speaking and the Milroy-type work in speech networks to examine the Ferguson-coined phenomenon of diglossia and the Fishman-extended relationship between societal diglossia and individual bilingualism to look at the historical problem and enduring question of language. 


\title{
CHAPTER III
}

\section{TOWARD AN ETHNOGRAPHY OF SPEAKING IN A MENNONITE COMMUNITY: AN INSIDER-OUTSIDER FRAMEWORK}

\begin{abstract}
Moving toward some heuristic schema of inquiry, open to questions and answers not foreseen, and closed to a routine of precoded content, an ethnographer said ...

If one starts from social life in one's study, then the linguistic aspect of the ethography requires one to ask what are the communicative means, verbal and other, by which this bit of social life is conducted and interpreted? What is their mode of organization, from the standpoimt of repertoires of codes? Can one speak of appropriate and inappropriate, better and worse uses of these means? How are the skills entailed by the means acquired, and to whom are they accessible? These guestions lead one into the territory of the other starting point. If one starts from language in one's study, then ethnography of the linguistic work requires one to ask, who employs these verbal means, 10 what ends, when and where and how? What organization do they have from the standpoint of the patterns of social life? (p.
\end{abstract} 83).

Del Hymes (1980)

\section{STARTING FROM LANGUAGE}

Sensitive to language situations in Mennonite speech communities north of the fortyninth parallel (for I learned rules for "speaking Mennonite" at home in Canada, and observed code-choosing and code-mixing after the family migrated to the United States), and concerned about educational situations in Anglo-American speech communities south of the line (for I learned rules for "speaking English" in schools in the United States, and trained in universities 
to teach English and to oversee schooling in multilingual, multicultural communities), I presented my committee with two reasons for undertaking an ethnography in Canada. Both started from language. First, the history of English language dominance in Canadian schools after the 1890 s, described in detail in Chapter I, apparently was repeating itself in some American schools to the south. For, in the aftermath of the 1982 proposed English Language Amendment to the U.S. Constitution (Daniels, 1990a; Judd, 1990; Marshall, 1986), policymakers in sixteen states had passed English-only statutes stripping linguistic minorities of their language rights in education (Daniels, 1990b). So the historical problem of English-only attitudes, policies, and goals in Anglo-Canadian schooling at the start of the twentieth century remained a problem in Anglo-American schooling near the end of the century. Second, the situations of diglossia and bilingualism, described in detail in Chapter II, evidently remained widespread and persistent in some ethnic communities (Manitoba, 1983a, 1983b, 1989a 1990), the United States (Fishman, 1989), and elsewhere (Ferguson, 1985; Fishman, Tabouret-Keller, Clyne, Krishnamurti, Abdulaziz, 1989). While trends toward cultural pluralism in Canada fostered views that "heritage languages" are schoolworthy (Fishman, 1985b, 1989), a legacy of English dominance in the United States renewed old attitudes that English-only was nationworthy, therefore schoolworthy. Such views of language and their bearing on schools were rarely given the attention they deserve (Ashworth, 1985; Baron, 1990; Bernstein, 1986;; Burnaby, 1987; Combs \& Lynch, 1990' Coulmas, 1984; Daniels, 1990a; Davis, 1990; Drake, 1984; Gonzalez, 1990; Gonzalez, Schott, \& Vasquez, 1990; Jernudd \& Rubin, 1971; Kloss, 1966; Marshall, 1986). So the Mennonite speech community in Canada presented itself as an ideal site for the study of language attitudes, policies, and goals in schooling. Given history, pre-existing models, and intuition, 1 proposed an insider-outsider approach to the ethnography of speaking in a Mennonite community. My committee accepted the rationale, and I undertook the fieldwork during the summers of 1989 and 1990. 


\section{A Century of Language Education Debate}

Canada's language education debate began in the 1890 s, the decade when the Manitoba Legislature, joined by the Manitoba's system of public schools, laid the English-only plank in the conflicted language education platform. Between the 1890s and the 1920s, the historical language debate shifted from a mainstream question of English and French in Westem Canada, to a sidestream question of English and German in southern Manitoba. The so-called "Manitoba School Question," an English-only initiative for school reform, eventuated in "One People, One Language, One School System" policies and goals for all linguistic minorities. These Englishonly attitudes instituted between the 1890s and 1920s, prevailed in Manitoba public schools until the 1960s. Then, between the mid-1960s and the mid-1970s, when the "uniformizing ethos, " found "wanting in many ways, by many groups, and in many places" pointed the way toward an "ethnic revival" (Fishman, 1985, pp. 489-517), Canadian social planners introduced a new direction in Canadian language policy; Manitoban legislators proposed a new initiative in Manitoba language educational policy and practice; and communities of linguistic minorities petitioned local school policy-makers for bilingual programs in heritage languages. The new direction dubbed the "Official Languages Act" in 1969, the Canadian "Charter of Rights and Freedoms" in 1982, and "Multiculturalism Within a Bilingual Framework" in the 1988, guaranteed "language education choice" to all linguistic minorities in Canada. Yes, policies and goals in Canada and Manitoba had changed. But had attitudes changed? To begin the inquiry, I borrowed some pre-existing models and intuition and approached the inquiry as both an insider and an outsider.

\section{Pre-existing Models and Intuition}

Hymes talked about steering between pre-existing models and intuition to engage in an "emic-etic" dialectal (Sapir, 1970). Given this orientation to inquiry, I designed an insideroutsider approach to the ethnography of speaking. Starting from intuitive knowledge of 
language in a Mennonite speech community, then, I restated the general question of sociolinguistic research (Fishman, 1972):

Who employs these verbal means [English, vernacular German, and classical German], to what ends, when and where and how? What organization do [members of the speech community] have from the standpoint of the patterns of social life (Hymes, 1980, p. 83).

In the particular situation of the Mennonite speech community and its schools, I made a significant distinction between the use of language "outside the classroom" according to norms "inside the local community" (Hymes, 1980):

Some essential light can be shed by knowledge of language development as it occurs outside the classroom . . . according to the norms of local cultures. One would want to know what kinds of use of language are valued, which users of language are valued, how these values are exhibited, experienced, and acquired. One would want to know how the relationship between language use in school and language use outside of school is viewed, where there is continuity, where conflict, where compartmentalization (Hymes, 1980, p. 72).

To follow the direction of continuity and change from the perspectives of both an insider and an outsider, I adopted Hymes' (1986) model of the ethnography of speaking inside the community, outside the school, Milroy's (1986) concept of the ethnographer as an insider-outsider or a

friend-of-a-friend, and proceed to look at the particular language phenomenon characterized by Ferguson (1959) as diglossia and by Fishman $(1967,1980)$ as societal diglossia and individual bilingualism.

Insider-Outsider Anproach to Ethnography. Like Hymes $(1974,1986)$ who reduced the scope of the ethnographies of speaking to small-scale studies of communities and their schools, I drew distinctions among "speech community . . . speech field . . . speech network." Then I integrated these distinctions with some insider information about shared rules for language form and function (Hymes, 1986, pp. 53-56). Tentatively:

[The Mennonite] . . . speech community is defined as a [southem Manitoba] community sharing rules for the conduct and interpretation of speech, and rules for the interpretation of . . . [ two varieties of German and a variety of English]. Both conditions are necessary. 
The [Mennonite] . . . speech field . . . can be defined as the . . range of . . . communities [Kildonan on the North End of Winnipeg, the East Reserve approximately 50 kilometers southeast of Winnipeg, and the West Reserve, approximately 100 kilometers southwest of Winnipeg] within which a person's knowledge of ... [High German, Low German, and English] and speaking rules [for Traditional Mennonite diglossia, one $\mathrm{H}$ and one $\mathrm{L}$, or Modern Mennonite diglossia, two $\mathrm{Hs}$ and one L] potentially enables him [or her] to move communicatively.

Within the speech field must be distinguished the [Mennonite] speech network, the specific linkages of . . . [local policy-makers, educators, and parents tied to German language education] across communities.

In sum, . . . [a Mennonite's] speech community may be . . . [Kildonan, East Reserve, or West Reserve] . . . or portion of it; one's speech field will be delimited by one's repertoire of patterns of speaking [High German, Low German, and English]; . . . [A Mennonite's] speech network is the effective union of these last two (adapted from Hymes, 1986, pp. 54-55).

Given this model of a speech community, a speech field, and a speech network, I

borrowed Ferguson's (1959) classic concept of diglossia and Fishman's $(1967,1980)$ interactive

concept of diglossia and bilingualism redefined the particular way of speaking in a Mennonite

community. Tentatively, I defined the traditional repertoire of Mennonite diglossia as two

varieties of the same language, one $H$ and one $L$ (Ferguson, 1959), and the modern repertoire of

Mennonite diglossia as a complex pattern of two Hs and one L (Fishman, 1980):

TRADITIONAL MENNONITE DIGLOSSIA is a relatively stable language situation in which, in addition to the primary dialects of the variety (which may include a standard [Plautdietsch] or regional standards [Chortiza or Old Colony and Molotschna or Volga derived from the Danzig, Marienburg and Elbing communities with borrowings from Groningin and Holstein]), there is a very divergent, highly codified (often grammatically more complex [phonemically, morphemically, and syntactically) superposed variety [Hochdeutsche], the vehicle of a large and respected body of written literature, either of an earlier period [the sixteenth century reformation] or in a different speech community [Zurich and Wittenburg], which is learned largely by formal education [catechism] and is used for most written and formal spoken [sacred] purposes but is not used by any sector of the community for ordinary [secular] conversation (adapted from Ferguson, 1959; R. Epp, 1987).

MODERN MENNONITE DIGLOSSIA is a complex case of $H$ as classical, and $L$ as vernacular, the two being genetically related . . . an instance of dual Hs in conjunction with a single $\mathrm{L}$, one $\mathrm{H}$ commonly being utilized for ethnically encumbered or traditional $\mathrm{H}$ pursuits and the other for ethnically unencumbered or modern pursuits. For example . . . [the RussianMennonites] reveal a complex form . . . involving High Luther Bible German 
[Hochdeutsche] and English as $\mathrm{H}$ and [Plautdietsch] as L (adapted from

Fishman, 1980; R. Epp, 1987).

Given this diglossic situation, I returned to Hymes' $(1974,1986)$ ethnography of speaking, a sociolinguistic system of a community that starts from language. So, Hymes' components of speech organized mnemonically as components of SPEAKING, namely setting or scene, participants, ends or purpose, act sequence, key or tone, instrumentalities or code, norms or rules, and genre, permitted me to concern myself with relationships between language and ethnicity in the local community and its local schools.

Insider-Outsider Role of Ethnographer. Like Labov (1972) and Milroy (1986), I concerned myself with some insider-outsider issues related to the problem characterized in the sociolinguistic literature as the "Observer's Paradox" (Labov, 1972, p. 209):

The aim of linguistic research in the community must be to find out how people talk when they are not being systematically observed; yet . . obtain these data by systematic observation .... . One way to overcome the paradox is to break through the constraints of the interview by various devices which divert attention away from speech, and allow for the vernacular to emerge. This can be done in . . . intervals and breaks which ... involve the subject in questions and topics which recreate strong emotions he has felt in the past, or involve him in other contexts (Labov, 1972, p. 209).

To solve the problem of how to obtain representative data, I borrowed methods both Labov (1972) and Milroy (1986) used to study relationships between language and ethnicity.

Labov (1972), for example, in his studies of Martha's Vineyard and New York City's Lower East Side, tackled the problem of how to obtain natural speech by considering the social context of the interview. To get beyond the formal style of speech associated with the interview, he interrupted the interview and asked speakers to read text, word lists, and paired words, and to tell stories. Thus, he isolated careful styles of speech from casual styles, and hypercorrected patterns of speech from vernacular patterns.

Milroy (1986), in her studies of Belfast's Ballymacarrett, Clonard, and Hammer communities, pursued the problem by introducing the significant notion of fieldworker as both an insider and an outsider, or a friend-of-a-friend. "Between them," an insider as a collector of 
primary data and an outsider as a controller of interaction with primary groups, "they may have access to a greater stylistic range than either can have, working alone" (Milroy, 1986, p. 41). Milroy observed, too, that women who assume an insider-outsider role are viewed with less suspicion than men, and a solitary woman is to be regarded as less threatening and "therefore more likely to be able to collect large amounts of data" (Milroy, 1986, p. 44). A more detailed description of Milroy's concept of the fieldworker and speech networks continues in this chapter in the section on methods.

\section{An Insider-Outsider Framework}

Selectively, then, 1 connected pre-existing models and intuition to build an insideroutsider framework. First, Hymes' $(1974,1986)$ model of speech community, field, and network enabled me to reduce the scope of the ethnography to a small-scale study of language education inside a local community and outside the local school. Second, Ferguson's (1959) classic concept of diglossia and Fishman's $(1967,1980)$ interactive concept of diglossia and bilingualism permitted me to make a basic assumption about language: that diglossia is a widespread societal arrangement, that bilingualism an individual asset or debit, and that bilingualism without diglossia is a transitory situation leading inevitably to unstable bilingualism and eventual monolingualism. Third, Labov's (1972) and Milroy's (1986) concerns about the problem of obtaining representative, the so-called "Observer's Paradox, " led me to approach the entire process of inquiry as both an insider and an outsider. Fourth, Hymes' $(1974,1986)$ components of SPEAKING guided input leading to description.

Putting it all together then, I started with the question of language: Who uses what language with whom, when, where, and why? I assumed an insider-outsider persona upon entering the Mennonite speech community. I approach an insider-oussider imterview as a speech event with intervals and breaks between speech acts of "act sequences" in the primary settings of the home, the congregation, and the school. I will devole the remainder of this chapter to the 
description of entering the Mennonite speech community during the summers of 1989 and 1990, interviewing speakers, and obtaining data representative of traditional and modern Mennonite diglossia and its bearing on schools.

\section{ENTERING THE MENNONITE SPEECH COMMUNITY: SPEECH EVENTS DURING THE SUMMER OF 1989}

My Mennonite family name linked me ethnicully to the first Russian-Mennonite immigrants to Manitoba who arrived aboard the riverboat Imternational on 23 July 1874 (Driedger, 1990, p. 13). Deemed an insider by virtue of my relationship to "Widow Rutzloff" whose named appeared on the Shantz List of Mennonire Immigramts, 1874-1880 (Plett, 1987, p. 73), and to her son "Hein Ratzlav" whose name appeared on the Quebec Ship Lists, 1874-1875 (Plett, 1987, p. 63) -- yet an outsider by virtue of my presence as an Anglo-American language researcher and a solitary woman from Oregon, whose name appeared on appointment calendars as "Ratzlaff-Swinney" -- I assumed an insider-outsider persona with considerable authenticity (Milroy, 1986, pp. 40-46).

\section{Assuming an Insider-Outsider Persona -- Months Before}

Gradually I "re-oriented" myself to ways of speaking and knowing in a community of people with whom I shared a common history and a common language linked to ethnicity (Wax, 1971, p. 14). Three events between February and July of 1989, stand out as having contributed in critical ways to my re-socialization and entry. The first, a small-scale pilot study of language and ethnicity I carried out in a Mennonite community sited in the United States, gave me firsthand experience with the "Observer's Paradox." The experience prompted me to embrace the problem by designing a mechanism for feedback into the ethnography (Bales, 1979; Hymes, 1980; Sapir, 1933). I accomplished this by assuming an insider-outsider role and approaching the interview as a speech event, a sequence of speech acts with breaks and intervals, discussed 
above and again in detail below. The second event, a series of letters and telephone conversations with four Mennonite elders in Canada (Journal, 1989, pp. 1,2,15,46), linked me as a "friend-of-a-friend" from the very day I entered the community (Milroy, 1986, pp. 46-47). The mutual "exchange of tokens" (Milroy, 1986, p. 41) and the associated "rights ... obligations" (Bales, 1979, 11-18), in this case the naming of a "friend" in exchange for the sharing of findings, together with the right to gain access and the responsibility to refrain from recording electronically, eventually enmeshed me in networks of speaking relationships "outside the classroom according to the norms of the local community" (Hymes, 1980, p. 72). The third event was the rite of entry itself.

Crossing the Forty-ninth Parallel -- The Day of 3 July.

Crossing the forty-ninth parallel at Emerson, I travelled toward my destination, Winnipeg. Awaiting me there, on the North End, at the Centre for Mennonite Brethren (MB) Studies in Canada, were a summer residence on the MB campus, a work-study space in the MB Archives, and a grand tour charted by the elders, all marking my entry the day of 3 July.

Driving north along the Highway 75, parallel to the Red River, my destination still an hour away, I thought about the language history of the Manitoba prairies. Ahead, at the confluence of the Red and Assiniboine rivers lay "The Forks" at Fort Garry, one of the linguistic crossroads in the history of North American and the center of present-day Winnipeg (named by the Crees, win meaning "muddy" and nipee meaning "water"). "The Forks" or Upper Fort Garry, as it had been called for more than two-hundred years, connected the trade routes of the British in Upper Canada, the "vast territory of the Canadian northwest between the Great Lakes and the Rockies" granted to the Hudson's Bay Company (Driedger, 1990, pp. 1315), with those of the French in Lower Canada, the Northwest Company in Montreal and its connections to European trade routes. There aboriginals, trappers, and farmers exchanged goods and services in English, French, Cree, Chipawayan, Dakota/Sioux, Ojibway, Island Lake 
Cree, Chinese, Punjabi, Yiddish, Scotrish, German, and Ukrainian. Yes, I thought, "The Forks" at Fort Garry was one of the linguistic crossroads of North America -- the very site where the heritage languages taught in Manitoba public schools today first came in contact.

\section{Touring the Historical Mennonite Reserves -- The Day of 3 July}

Still driving north, parallel to the Red River, I thought about the Mennonites who passed through the Forks on their way to the "Mennonite Reserve" in 1874 (Driedger, 1990, p. 13). That year, five boatloads of German-speaking Mennonite immigrants from Russia stopped briefly at Upper Fort Garry, bartered for supplies in Low German, "continued on to disembark at the forks of the Red and Rat rivers" where they rested in sheds and tents, drew water from a now legendary well, and "gave thanks" in High Gcrman. The secular exchanges in Low German and the sacred exchanges in High German increased on the prairies, between 1874 and 1890; for those years marked the arrival of the first wave of 7,000 Russian Mennonite immigrants to Canada, known then and still today as Kamadier (Canadians). These Germanspeaking Kanadier settled on the eight townships known as the "East Reserve" and on the seventeen townships known as the "West Reserve" (Epp, 1974, p. 200; Friesen, 1985) -- they broke sod, established villages, built schools, and, in 1890, came into conflict with English and the Union Jack, "a rationale for [Canadian] public schools . . . ." In 1916, after twenty-five years of passive resistance to English-only trends in Canada, the Kanadier from the rural reserves petitioned the Manitoba Attomey General for the right to preserve Deutsche und Religion in Mennonite private schools (Epp, 1974, p. 333). By 1920, the year the British Privy Council and Canadian Supreme Court declared the language education clause of 1873 Canadian Priviligium not binding on the Manitoba government, the population of German-speaking Mennonites in Manitoba had increased to 21,300 German-speakers. While the population up to that time was largely concentrated on the rural reserves in southern Manitoba, the Mennonite speech community was on the brink of change (Epp, 1974). 
The 1920 Supreme Court decision and the aftermath jolted Mennonites across Canada. In Manitoba alone, an estimated 3,800 Kanadier left for Mexico and Paraguay to protest the rules compelling Mennonites to close German Mennonite private schools and to send their children to English national schools. The Kanadier who remained on the East Reserve and the West Reserve after the 1920, acquiesced to sending their children to English-only schools. And within the same decade, between 1922 and 1930, the Kanadier who remained on the Canadian prairies hosted the second wave of 21,000 Russian-Mennonite immigrants known then and today as Russlaender (Russians). In less than two decades, between 1947 and 1960, the Kanadier and the Russlaender together hosted the third wave of 7,000 Russian-Mennonite immigrants called Neueingewanderte (newly immigrated), and the returning wave of Kanadier from Mexico and Paraguay after the 1960s, called Auswanderer (emigres) (Dyck, 1974, pp. 201-206; Klassen, 1989, p. 5). Some Russlaender, Neueingewanderte, and Auswanderer re-settled among the Kanadier in Manitoba, and sent their children to consolidated English-only public schools on the East and West reserves. Many, though, re-settled in the "Mennonite Ghetto" on the "North End" of Winnipeg (Journal, 1989), known historically as "Foreign Quarter," "New Jerusalem," and "CPR Town" (Driedger, 1990, p. 18), and sent their children to English-only public schools in urban Winnipeg.

Still driving north, heading into Winnipeg, I watched for landmarks. Passing "the Forks" at Fort Garry, I imagined the sights and sounds of an historical linguistic crossroads. Beyond the dome of the Manitoba Legislature, over the tracks of the Canadian Pacific Railway (CPR), across the bridge spanning the Red River, I reached my destination, the North End. The moment marked the end of a journey and the beginning of a grand tour. I collected my maps of historical sites and present-day settings, depicted in figures 10-13. The map of the historical Mennonite reserves in southern Manitoba, illustrated in figure 10, shows the geographic relationships of the rural East Reserve, the rural West Reserve, urban Winnipeg, and the 


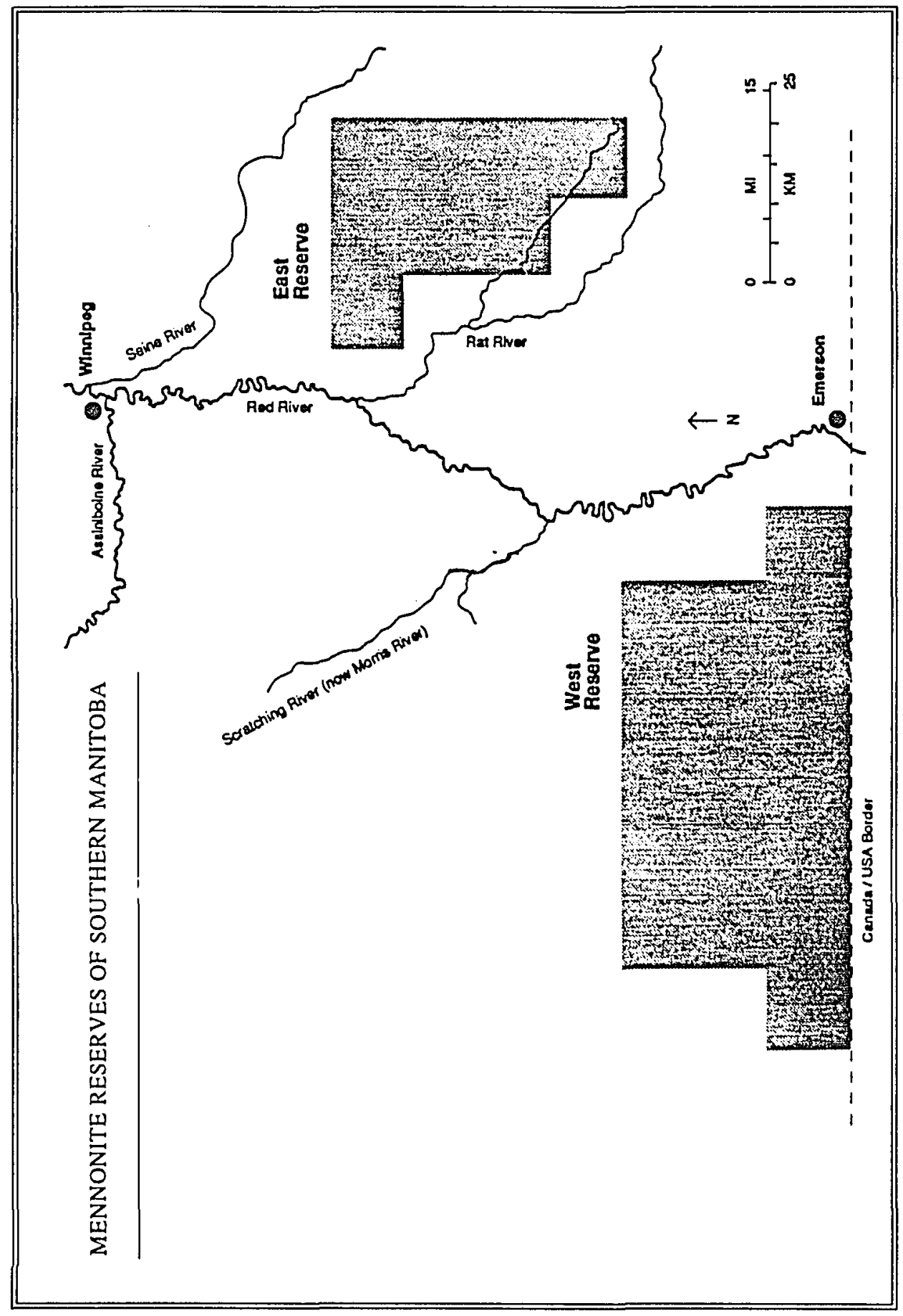

Figure 10. Mennonite reserves in southern Manitoba. A map of southern Manitoba shows the locations of the East Reserve and the West Reserve and their proximity to Winnipeg and the Canada/USA border. Source: Klassen (1989, p. 304). 


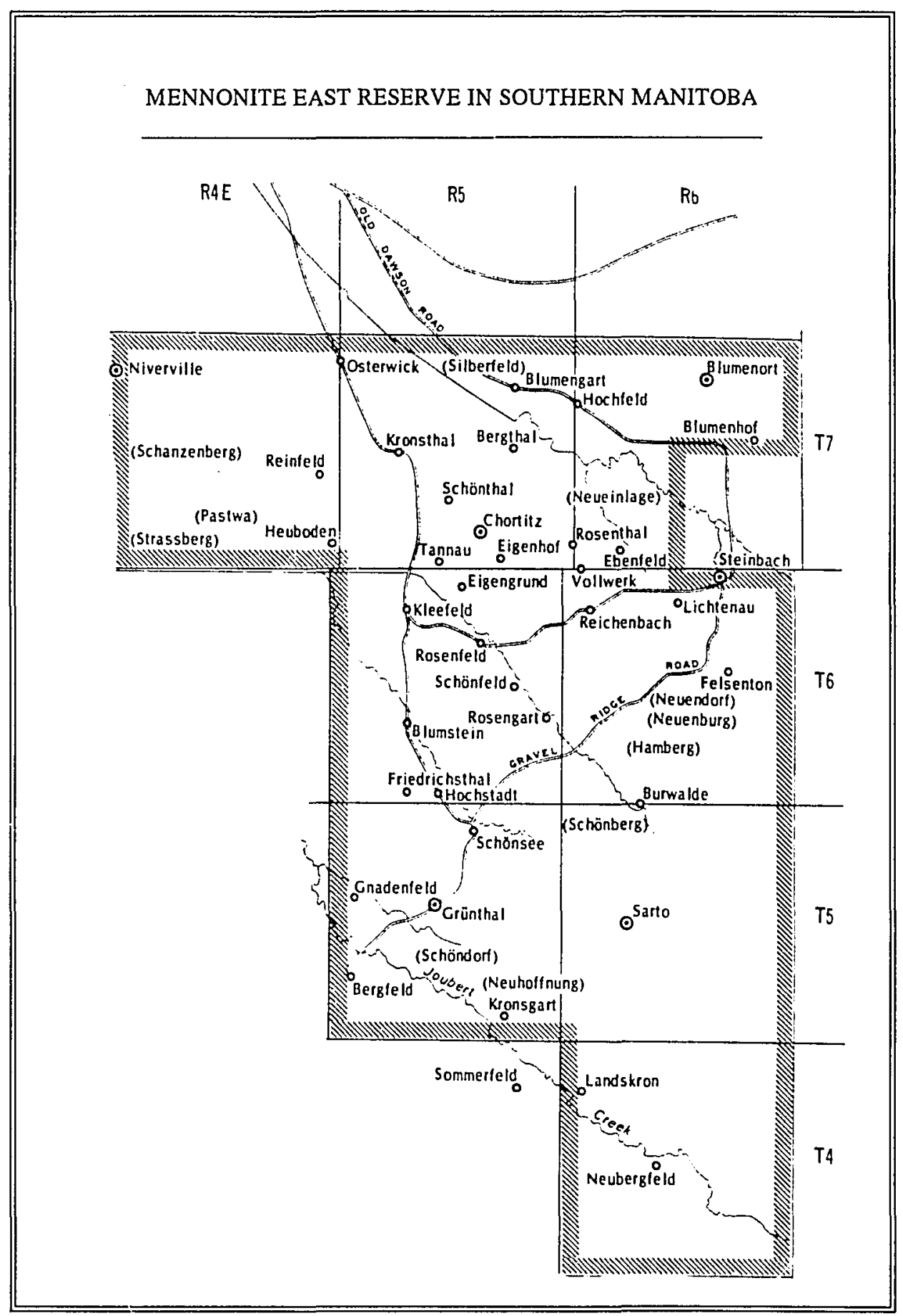

Figure 11. Mennonite East Reserve in southern Manitoba. A map of the East Reserve shows where the Mennonites first settled and where the movement to resist English and the Union Jack took foot. Source: Epp (1974, p. 213). 


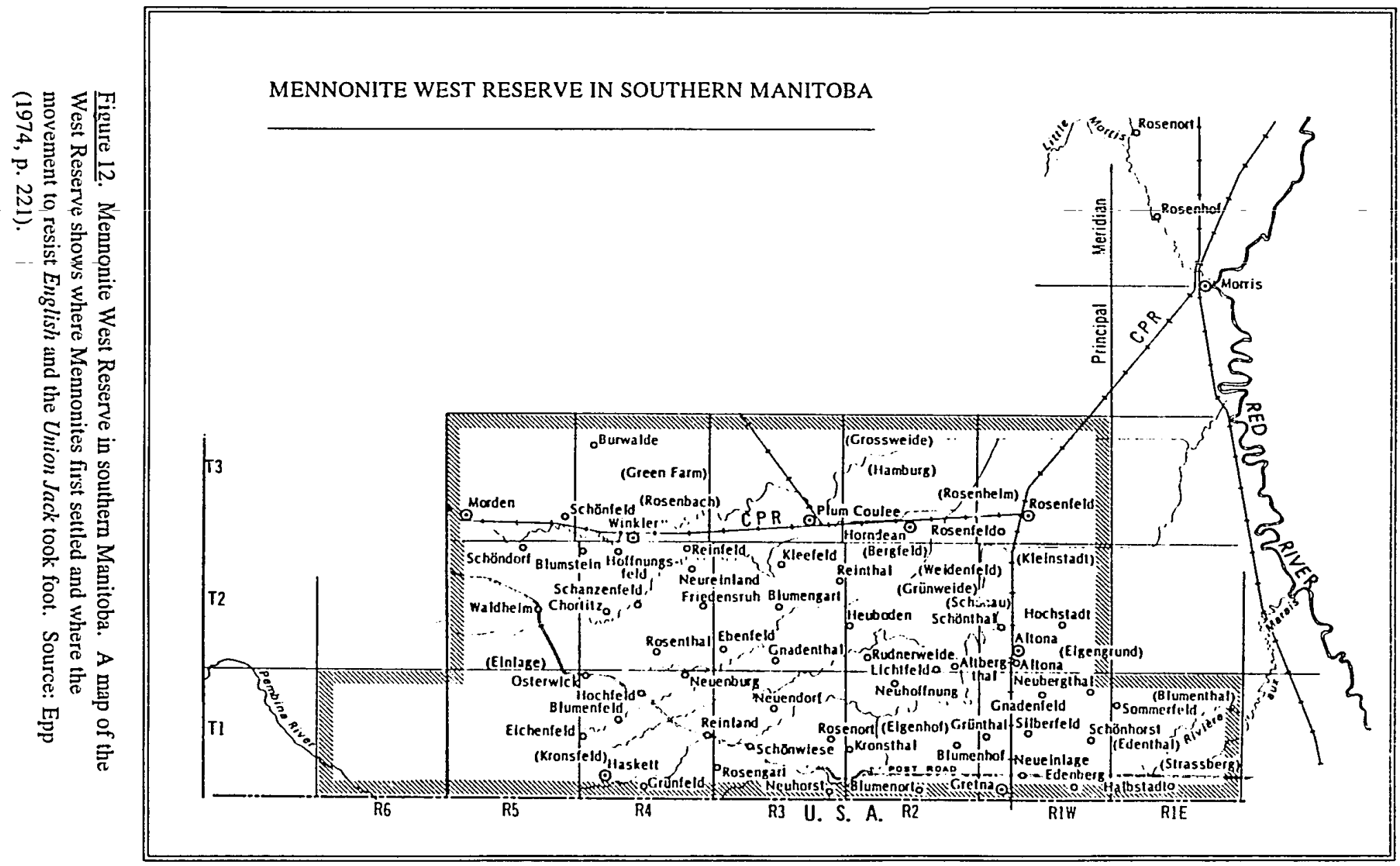




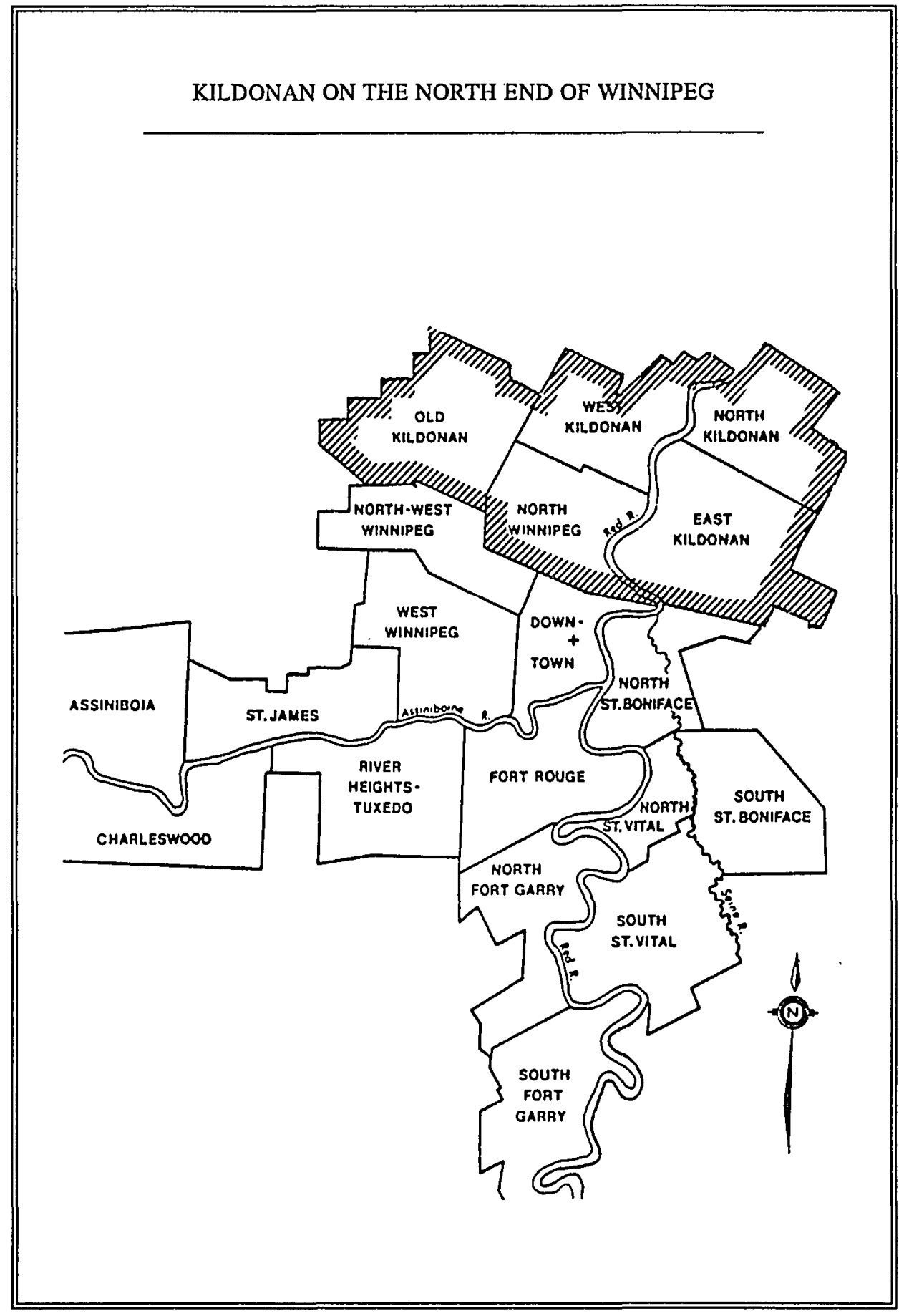

Figure 13. Kildonan on the North End of Winnipeg. A map of Kildonan on the North End shows an area of dense Mennonite population, referred to as the "Mennonite Ghetto" or as the "Foreign Quarter . . . New Jerusalem . . . CPR Town." Source: Driedger (1990, p. 18). 
Canada/USA border. Maps of the historical East Reserve and the historical West Reserve, illustrated figures 11 and 12 respectively, represent the geographic origin of the movement to resist English and the Union Jack took foot. And the map of the present-day North End or Kildonan, illustrated in figure 13, shows where I lived and studied for six weeks.

Touring the Present-day Mennonite Speech Community $\rightarrow$ The Week of 3 July

Over the threshold of the Centre |for MB studies, I introduced myself to "friends" as "Ratzlaff-Swinney." Mutually, "friends"|and I exchanged "tokens" or guarantees of "good faith" and laid the groundwork for a series of interyiews with community-minded elders in urban Winnipeg who were to facilitate the ethnography of speaking by opening doors to "friends" or "speakers" in the Mennonite speech community and its urban and rural speech fields. By the end of the week of 3 July, the grand tour of the Mennonite speech community had taken me inside the Manitoba system of public schools and inside the Mennonite system of private schools where I met and talked with "friends" and "friends-of-friends" -- all of whom eventually contributed to my understanding of the use of llanguage "outside the classroom" according to the norms of the local Mennonite speech community.

The grand tour itself took me to three fields in the present-day Mennonite speech community: the "North" field and the "North" or River Elast School Division serving the Mennonite population in the urban villages of Kildonan, the "East" field and the "East" or Hanover School Division serving the Mennonite population in Steinbach and rural villages of Hanover municipality, and the "West" field and the "West" or Rhineland and Garden Valley school divisions serving the Mennonite population in Wirikler, Altona, and the villages of the Rhineland and Garden Valley municipalities. Along the way, I stopped to talk with "friends" including the administrator of the Manitoba Department of Education as well as the heritage language coordinator and consultants to the English-Germian bilingual program, who all promote "Language Choice" in Manitoba public schools; the professors in the Mennonite Studies Centre 
at the University of Winnipeg who promote an interdisciplinary program in Mennonite Low German literature and language; the archivists at the Centre for MB Studies in Canada and at the Mennonite Heritage Centre who promote teaching and research in areas of Mennonite history, literature, and culture; and demographers at STATS Canada who disseminate Canadian census data on language, ethnic origin, place of birth, and schooling specifically, and population generally.

Census data I collected from these public and private research centers helped me understand abstract notions of speech community, speech field, and speech network in concrete terms. For example, I learned that the Mennonite speech community, with a population of 63,490 in the province, and 19,105 in Winnipeg, according to the 1981 Canadian census, represented the largest regional and local concentrations of Mennonites in the world (Statistics Canada, 1981, 93-931). Outside of the province, the Manitoba population figure represented thirty-three percent of the Mennonite population in Canada, nineteen percent of the Mennonite population in North America, and eight percent of the Mennonite population in the world, according to the 1984 Mennonite membership census of Mennonite communities around the world, illustrated in figure 14 (Friesen, 1985). Inside the province, within the system of Manitoba public schools, where the student population enrolled in German language programs was monitored by the Manitoba Department of Education in cooperation with the Manitoba Parents for German Education, the 1988 student census indicated that 87 percent of the 5,447 students enrolled in German language education, grades K-12, was concentrated in three speech fields of the Mennonite speech community -- an urban field in Kildonan on the North End of Winnipeg, with fifteen percent of Manitoba's German language students enrolled in one school division; a rural field in the historical "East Mennonite Reserve" southeast of Winnipeg, with twenty-five percent enrolled one school division; and a rural field in the historical "West 


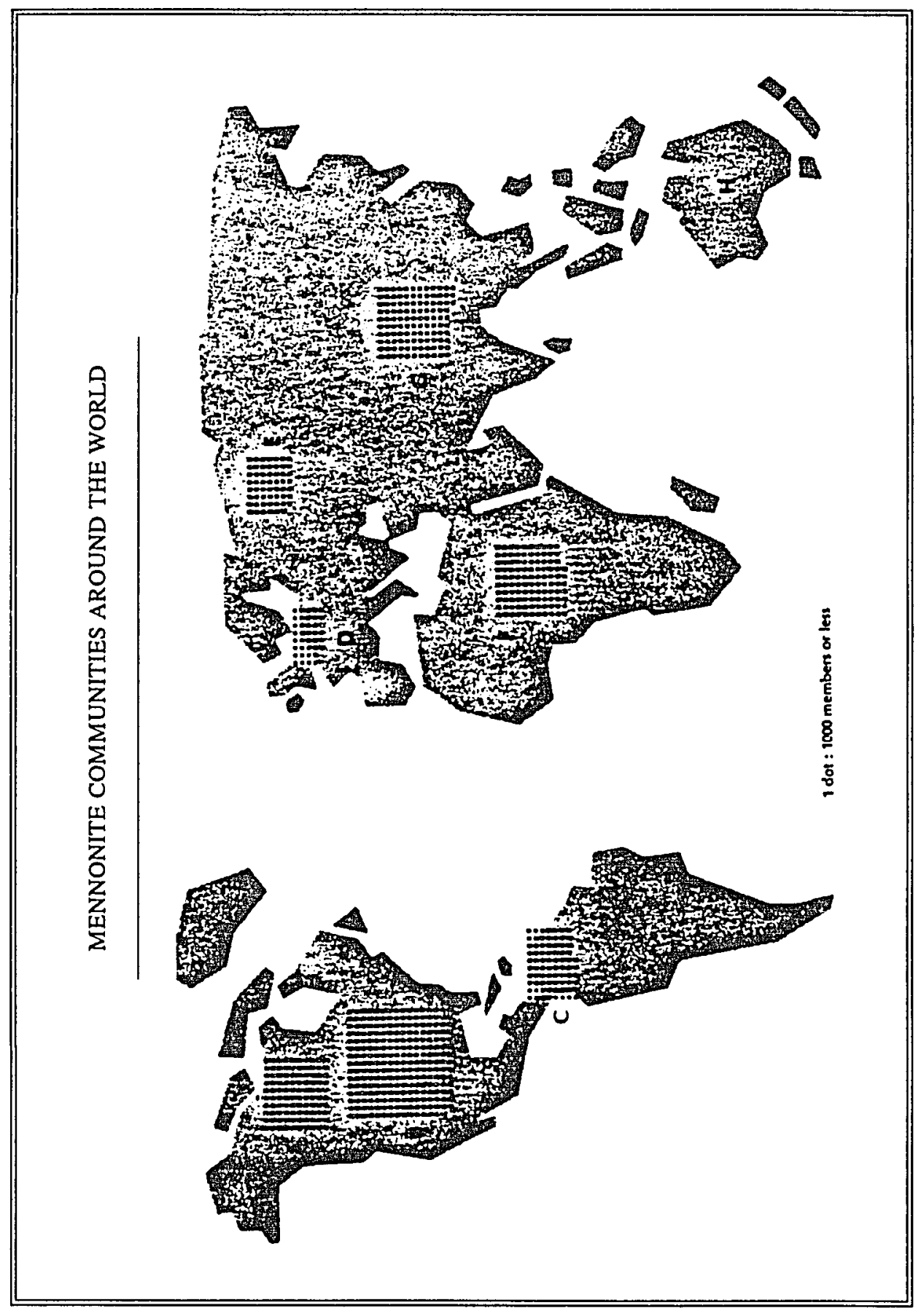

Figure 14. Mennonite communities around the world. A map of Mennonite communities around the world shows that the Mennonite population in southern Manitoba represents thirty-three percent of the Mennonite population, in Canada, nineteen percent in North America, and eight percent, in the world. Source: Friesen (1985). 
Mennonite Reserve" southwest of Winnipeg, with sixty percent, enrolled in two school divisions.

A closer look at the 1988 student census revealed disparity in the enrollment figures related to German "core" or "enrichment" programs and those related to English-German "bilingual" programs. For example, eighty-five percent of the 692 students enrolled in the English-German bilingual education program was concentrated in the K-8 program of the urban North school division in Kildonan, while the remaining fifteen percent was enrolled in the K-3 program of the rural East school division on the East Reserve (Manitoba Parents for German Education, 1988). The rural West school divisions offered no English-German bilingual program. The clusters of student interest in English-German bilingual programs in the North and East fields vis-a-vis the cluster of apparent student disinterest in the West field suggested to me that speech networks linked to German language education in the North, West, and East fields of the Mennonite speech community held different views of English-German bilingual education program.

I considered the piece of evidence important clue to the answer of the question -- Who uses what language with whom, when, where, and why? -- perhaps an indicator of continuity, conflict, and compartmentalization in the context of language education policy and practice in Manitoba schools. The answer, I thought, lay in the networks of parents, educators, and local policy-makers of the school divisions in the North, East, and West fields who knew "what kinds of use of language are valued, which users of language are valued, and how these values are exhibited, experienced, and acquired" (Hymes, 1980, p. 72).

\section{INTERVIEWING SPEAKERS IN MENNONITE SPEECH FIELDS: SPEECH EVENTS IN THE URBAN NORTH END AND THE RURAL RESERVES}

Starting from language, I crossed threshold of the North End, the East Reserve, and the West Reserve to elicit a picture of the physical setting, the cultural scene, and the diglossic 
situation in the Mennonite community and its schools. Having traced the historical language developments and their bearing on present-day educational policy and practice in local schools, I continued to steer between pre-existing models and intuition as I approached the interviews as an insider-outsider. Eventually, I hoped to discover which language varieties were valued, which speakers were valued, and how speakers exhibited, experienced, and acquired these attitudes in community and school (Hymes, 1980, p. 72). For the time, I treated the interviews as a series of speech events and speech acts, the questions and responses as heuristic input to description coded mnemonically as SPEAKING, and the linkages of parents, educators, and policy-makers to English-German bilingual education as speech networks. The remainder of this chapter is devoted to a description of the methods I used (a) to collect language and social data on fiftyseven speakers in the urban and rural speech fields of the community, (b) to treat the data as a sez̨uence of ethno-events and ethno-acts marked by components of speaking, and (c) to establish linkages between patterns of speaking and language education policies and practices. A complete discussion of findings can be found in Chaprer IV. Brief discussions of methods, instruments, and procedures follows below.

\section{Asking the Grand Tour Question -- The Week of 3 July}

The grand tour question -- Who uses what language with whom, when, where, and why? -- opened doors to "friends" and "friends-of-friends" inside the local community and permitted me to observe and participate in language situations and educational situations in local schools, both private and public. In a series of exchanges during the week of 3 July, Mennonite elders pointed to historical and theological collections the Centre for the MB Studies in Canada and the Mennonite Heritage Centre (Journal, 1989, pp. 1, 2, 6, 8, 10, 44, 46). And Manitoba policy-makers and educators directed me to statutes and administrative rules in the legislative archives (Journal, 1989, pp. 4, 5, 9, 21). I reviewed the literature from both sectors. Within a few days, Mennonite scholars at the university invited me to share early findings with a "forum" 
linked to the interdisciplinary program in Mennonite Studies (Journal, 1989, pp. 2, 44, 45, 46). Later, local policy-makers invited me to attend a special meeting of the school board (Journal, 1989, p. 54). I participated in both. Mennonites asked me not to "tape" my interviews and not to "survey" their friends (Journal, 1989, 1, 2, 10). I took hand-written notes instead. All described the lay of the land and named "friends" associated with the rural schools and villages of the East Reserve and West Reserve and the urban schools and villages of the North End. Some talked of the tradition of High German in the congregation, Low German at home and in the villages, and English in schools; others, of the trend toward English-German bilingual education in two local school divisions (Journal, 1989, pp. 3, 4, 5, 8, 9, 11, 13, 14, 21). I listened, observed, and asked more questions. By the end of the week of $3 \mathrm{July,} \mathrm{I} \mathrm{found} \mathrm{myself}$ enmeshed in a network of relationships with Mennonite law-givers, scribes, and preachers, on one hand, all concerned with catechism; and with Canadian law-makers, administrators, and teachers, on the other hand, all concerned with matters of language education. Having elicited a general picture of speaking during the week of $3 \mathrm{July,}$, moved from the grand-tour question to some insider-outsider questions afterward.

\section{Asking Insider-Outsider Questions -- The Weeks After 3 July}

To elicit patterns of speaking Low German, High German, and English systematically, I concerned myself with how to select speakers inside the community and how to ask questions to elicit a picture of language use in the home, the congregation, and the school, and how to assemble language and ethnic data that had a bearing on education. Still guided by pre-existing models and intuition, plus information gained from the grand tour and the grand tour question, I established (a) a set of criteria for selecting speakers, (b) a list of questions for giving informal structure to interviews, and (c) a database for entering and retrieving information on language and ethnicity in education. Later, I analyzed the language and social data for (c) repertoires of 
speaking and (d) linkages or networks of policy-makers, educators, and parents across the speech community and its fields.

Selecting Speakers. My initial list of three "friends" increased overnight to twelve friends, over three-weeks, to seventy-five friends, then decreased over six weeks to fifty-seven speakers as I decided who to interview and who not to interview. Selectively, I chose to interview only those speakers who met criteria tying them specifically to language education policy, practice, and promotion. So, a potential speaker had to be linked to the research problem and question either as a teacher or administrator with a role in implementing EnglishHigh German bilingual studies, a professor with a role in implementing Mennonite Low German studies, a school board member with a role in overseeing language education policy, or a parent with a role in preserving a High German language heritage or a Low German language heritage. Who these fifty-seven speakers are in terms of age, sex, education, occupation, ethnicity, and identity, and in terms of network structure will be described in described in Chapter IV. Eventually I found myself linked to them through a mutual interest in German language education in the Manitoba system of highe $r$ education, the Manitoba system of public schools, and the Mennonite system of private schools.

Asking Questions. Having decided who to interview, I initiated calls to potential speakers from a telephone in the MB archives, a place defined physically and culturally as a "Mennonite setting" where English, High German, and Low German are spoken. Usually, after a span of a few days, my telephone inquiry in English to potential speakers broke into a face-toface talk about High German, Low German, or English-German bilingual education. In interviews with educators, policy-makers, or parents in offices, libraries, cafes, meetinghouses, and residences, I observed "how things were said" and "what was said." I participated with speakers in interviews that extended into a sequence of speech acts with other participants. Typically, an interview lasted from one-to-three hours and was only the first speech act of a 
sequence of three to eight speech acts. Sequential acts generally occurred after a few days' break or a week's interval and involved the speaker in other contexts. Subsequent situations and contexts typically involved a speaker in a dyadic or triadic relationship with a co-educator, a supervisor, an elected official, a pastor, a spouse, a parent, a sibling, or a child. Subsequent events and acts often entailed a guided tour of a Mennonite village on the East Reserve or the West Reserve, a traditional Mennonite residence or meetinghouse, or a modern German-English bilingual school; an informal gathering of friends and family in a kitchen or dining room, in a restaurant, at a picnic-in-the-park; or a celebration in a community center. Depending on setting-scene, participant, and end or purpose, I found that I spent as much time as thirty-six hours with one speaker and as little time as one hour with six speakers. Altogether, though, I tallied 1,248 hours of study in the field, 208 hours of participation with fifty-seven speakers, and an average of three-and-one-half hours in each interview (Journal, 1990).

Assembling and Analyzing Language and Social Data -- The Weeks and Months After 3 July

What follows are exhibits and descriptions of methods and instruments I used to keep a record of language and social data and the procedures I used to analyze the data. Exhibit A, inserted as Appendix A (p. 160), is the list of questions titled "An Insider-Outsider Interview." Exhibit B, inserted as Appendix B (p. 170), is a chart titled "An Insider-Outsider Interview: Language and Social Data on Fifty-seven Speakers." Exhibit C, inserted as Appendix C (p. 172), is a series of six summaries, each labelled "Data Summary." Exhibit D, inserted as Appendix D (p. 179), is a chart labelled "Network Index Sort." Exhibit E, inserted as figure 15 , is a schematic of a speech network and its zones. Exhibit F, inserted as figure 16 , is a chart titled "Correlations Between insider-outsider questions and Hymes' Components of SPEAKING." Exhibit G, inserted as figure 17, is a list titled "Insider-Outsider Protocols" used to encode questions and decode responses related to Hymes' sociolinguistic system. These methods of assembling and analyzing the database of $\mathbf{5 7}$ language and social variables. 


\section{A SCHEMATIC OF MILROY'S NETWORK}

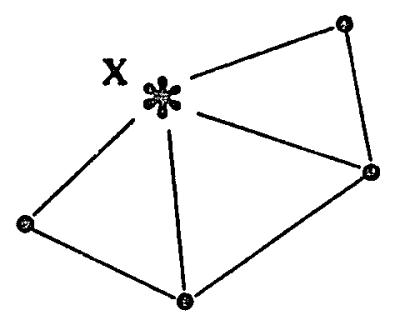

(a) High-density Network

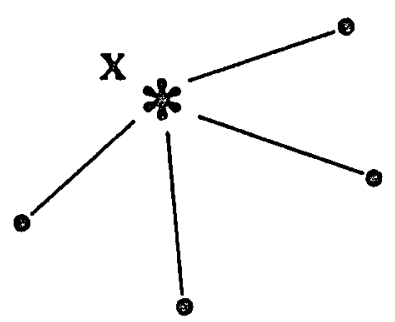

(b) Low-density Network

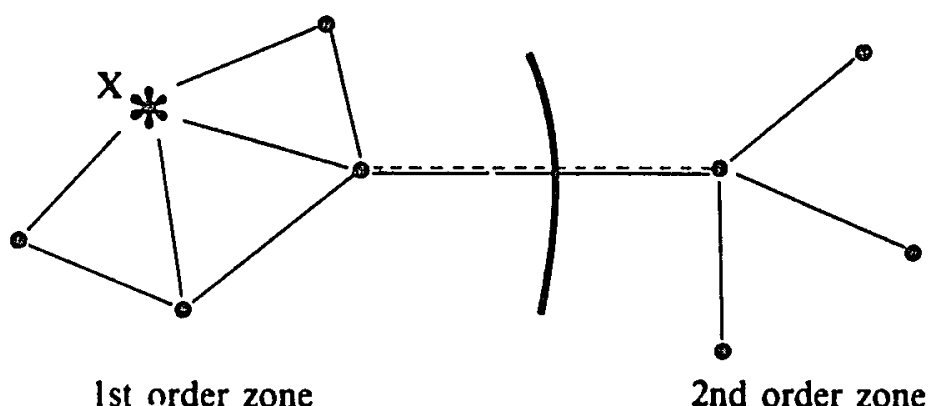

(c) High-density Network and Zones

Figure 15. A schematic of Milroy's network. A schematic of speech network illustrates three ty'pes of network structure: (a) a high-density personal network structure with $X$ ats the focal point of the network, (b) a low-density network structure with $X$ as the focal point, and (c) a highdensity personal network structure, showing first and second order zones with $X$ as the focal point. Source: Milroy (1986, pp. 20,48). 


\section{RELATIONS BETWEEN SPEAKING AND QUESTIONING}

Hymes' Components of Speech Insider-Outsider List of Questions

Setting and Scene $(S)=$ Questions 3, 4, 135

Time, physical place, culturall scene

Participants $(P)=$ Questions 1, 2, 5-14

Dyadic/triadic/monadic roles and relationships of speakers

Ends $(E)=$ Questions 40-81, 92-126

Purpose, goal, or outcome -- stated or unstated

Act sequence $(A)=$ Questions $1-135$

Message form -- "how things are said"

Message content -- "what is said"

Competence -- knowledge and interaction ।

Key $(K)=$ Questions 92-126

Tone or style of the message

Instrumentalities $(l)=$ Questions 92-126 ।

Codes -- use of English, High German, or Low German

Channels -- oral, written, or other communication

Competence -- skill in choosing, switching, mixingl codes

Norms $(N)=$ Questions 82-91, 127-135

Norms of interaction governing roles and relationships of men, women, children Norms of interpretation governing codes in homes, meetinghouses, schoolhouses

Genre $(G)=$ Questions 127-135

Insider-Outsider Interview -- speech event

"Story" -- speech act

Myths, legends, poems, tales, prayers, lectures, sermons $;-$ speech acts

Figure 16. Relations between SPEAKING and questioning. Schema derived from Hymes' components of SPEAKING relate to questions asked and data collected. Source: Hymes (1986, pp. 55-65). 
INSIDER-OUTSIDER PROTOCOLS

(a) Link and "anchor" to a "friend-of-a-friend" (Milroy, 1986, pp. 41-42).

(b) Exchange tokens of "good faith."

(c) Become enmeshed in the rights and obligations of the speech network.

(d) Participate in the insider-outsider interview as a "speech event."

(e) Guide interview unobtrusively with "a list of questions."

(f) Ask questions in English about German.

(g) Divert attention away from English (Labov, 1972, pp. 207-209).

(h) Relate questions to components of SPEAKING (Hymes, 1986, pp. 55-65).

(i) Record language and social data by means of handwritten notes.

(j) Capture data within an hour of each interview.

(j) Build database of language and social data.

(k) Encode and decode responses assisted by: COMPAQ portable computer; MICROSOFT WORD, a word-processing system;

SYSTAT, a quantitative research application; QUATRO, a qualitative research application.

(l) Analyze language and social data.

(m) Give attention to:

Scales of community, field, network;

Components of SPEAKING;

Their bearing on schools and schooling.

Figure 17. Insider-Outsider protocols. Protocols for entering the community, the field, and the network guide the incpuiry at each stage of the ethnography. Source: Adapted from Hymes' (1986), Labov (1972), and Milroy (1986). 


\section{Exhibit A: An Insider-Outsider Interview (Appendix A). "An Insider-Outsider}

Interview, " approached as a speech event with breaks and intervals between act sequences, permitted me to collect data on the use of English, High German, and Low German in the home, in the congregation, and in schools, according to local norms. At the same time, the approach permitted me to observe speakers in other contexts and thus served as a means of "accounting for (and reducing) the effect of an . . o observer on the data" (Milroy, 1986, p. 43). The list of questions is derived from Labov's $(1966,1972)$ studies of New York City's Lower East Side and Martha's Vineyard, from Fishman's (1971) study of the Barrio, from Milroy's (1986) study of Belfast, and from my pilot study of a Mennonite community in the United States (1989). Upon entering the Mennonite community in Manitoba, I refined the list of questions based on my talks with elders. After the "grand tour, "I piloted the list of questions with several elders. Because I observed that my use of the word "survey" raised speakers' "red flags" -- perhaps, as one speaker suggested, because it connoted a mass mailing with low returns -- I promptly relabelled the survey "a list of questions." Afterward, I became the sole user of the instrument. I myself recorded observations on the list of questions, either with a speaker at the close of an interview or in solitude within an hour of the event depending on whether my speaking relationship was informal or formal. The record became a database of language and social variables on 57 speakers.

Exhibit B: Language and Social Data on Fifty-seven Speakers (Appendix B). The second exhibit is a chart titled "An Insider-Outsider Interview: Language and Social Data on Fifty-seven Speakers." The exhibit represents the database I created from the collection of twenty-seven language and ethnic variables on fifty-seven individual speakers. With a few exceptions, the base is a repository of "qualitative data" on language and ethnicity rather than "quantitative data." 
Variables numbered Q1 to Q10 and Q39 correlate with questions 1-10 and question 39 on the "list of questions." These variables represent individual ethnic characteristics such as age; sex; generation in Canada; and Mennonite/non-Mennonite status of ethnicity, education, marriage, and residential neighborhood. Similarly, variables Q11(-17) to Q32(-38) and Q40(46) to Q121(-126) correlate with that sequence of questions on the question list. These variables reflect what speakers described as the historical choice of language use in the home, congregation, and school, as well as the present-day choice of language use in the home, congregation, and school. Variables numbered parenthetically on the exhibit are not represented in the database because they represent language and ethnic data collected from a speaker about his or her parents' and siblings' use of language. The family data, while interesting, represent a speaker's "impressionistic" and "hazy" recollection of historical events.

Variable numbered Q82(-91), the network index, is a quantitative measure of network strength. A speaker's network index is calculated by assigning points to the five conditions of network membership that he or she fulfills (Blom \& Gumperz, 1986; Bortoni-Ricardo, 1985; Gal, 1979; Milroy, 1986). The conditions of a Mennonite speech network below are adapted from Milroy's work (1986, pp. 139-144):

1. Locale of school and/or residence ties to a Mennonite speech field $=1$ point.

2. Both kinship and nuclear family ties to the Anabaptist-Mennonite ethnic tradition $=1$ point.

3. Language education policy, practice, promotion ties to English-High German bilingual education and/or Low Gernan studies $=1$ point.

4. Gender ties $=1$ point.

5. Voluntary association or leisure ties $=1$ point.

Scores range from zero for someone who fulfills none of the conditions to five for someone who integrates closely into the community in the sense that kin, school, and friendship ties are solidly contracted within the network. Condition one is an indicator of nerwork density and conditions 
two, three, four, and five are indicators of network multiplexity. Both density and multiplexity serve as mechanisms of enforcement and are discussed below in a section on analyzing language and social data.

Variables Q127 to Q134 relate to the history of language policy in the Manitoba Legislature. Few speakers had ready knowledge of this history although some speakers whose families had lived in the community since the 1920s shared feelings of loss and dislocation associated with the exodus to Mexico and Paraguay after the 1916 Act and the case of Manitoba Attorney General v Hildebrand and Doerksen (1919). Additionally, many speakers expressed feelings of optimism associated with the bilingual and multicultural policies in the $1960 \mathrm{~s}, 1970 \mathrm{~s}$, and 1980s. Given these responses to question, I relied on secondary sources for an official history and on primary sources for an anecdotal history. Finally, variable Q135 is an openended series of responses recorded in a journal but not in the clatabase. These responses prompted the title Telling Stories (Out of School).

Exhibit C: Data Summary (Appendix C). The "Data Summary" derived from Exhibit B, "Language and Social Variables on 57 Speakers" above, is a series of six reports on language use in the Mennonite speech community. Three reports show language use in the home, in the congregation, and in the school and are organized under the headings "Mennonite Speech Community and Speech Fields" and "Mennonite Speech Community and Speech Repertoires" derived from variables $\mathrm{Q} 3, \mathrm{Q7}$, and $\mathrm{Q} 10$, social variables of of location, ethnicity, and intragroup ethnicity, and variables Q40 and Q92, Q68 and Q107, and Q54 and Q1 14, variables of home language, congregation language, and school language. In most cases data were validated by direct observation of code-choosing, code-switching, and code-mixing in the context of interviews asi speech events.

Exhibit D: Network Index Sort (Appendix D). The "Network Index Sort," derived from Exhibit B, "Language and Social Variables on 57 Speakers", variable Q82 above, is a 
report on density and multiplexity of network strength introduced above. To obtain the report, I sorted the database with a three-step procedure: one, a sort by network index score, variable Q82; two, a sort by Mennonite ethnicity, variable Q10; and three, a sort by present-day language choice in school, variable Q107. The procedure isolated twenty-nine speakers with a network index of five:| sixteen were Kanadier and thirteen were Russlaender. Given the configuration history, ethnicity, language, and network structure, I expected to find evidence of continuity, conflict, and change in their attitudes about the role of language in education.

Exhibit E: Network Structure (Figure 15). So, the Kanadier Network and the Russlaender Network and their attitudes about language became the object of descriptive analysis in Chapter IV. For after two decades of sociolinguistic research, ethnographers considered speech retworks to be a strong indicator of enforcement mechanisms and a useful instrument in sociolinguistic analysis. Fishman's $(1967,1971,1980,1986)$ model of open and closed networks made binary/distinctions between fluid interaction in open networks or compartmentalized interaction in closed networks. But Milroy's (1986) model of speech networks and Bales' $(1950,1965 \mathrm{a}, 1965 \mathrm{~b}, 1970,1979)$ model of communication networks revealed a more complex structure of interaction. Milroy (1986) based network structure and strength on cluster, the content that ties speakers to sector (for example, language education policy and practice in public schooling); densin, the ratio of possible relationships to the total actual relationships that link speakers liogether; and multiplexity, the number of strands that link speakers (density and multiplexity together, for example: same neighborhood/household, same kinship group, same family, same school/employer, same gender, and same voluntary leisure association) (Bales, 1979; Milroy, 1986). So Milroy (1986) conceived speech networks to be either "Imultiplex" and "many stranded" or "uniplex" and "single stranded." In the multiplex network, speakers linked with others in more than one linguistic capacity. In the uniplex network., speakers linked to others in one linguistic capacity only. The schematic of a speech 
network, figure 15, illustrates the structure of two types of networks and the zones of a network. The first network type, figure 15a, is a "high-density" speech network: one with speech repertoires bonding one friend to another hypothetically in terms of a Mennonite speech field, a territorial boundary; Mennonite ethnicity, a kinship tie; Mennonite family and kinship tie; English-High German bilingual education and Low German studies, a language education tie; a gender relationship; and a voluntary leisure relationship. These bonds between friends and others eventually became factors contributing to an index of ethnicity in speech networks. The second network type, figure $15 \mathrm{~b}$, is a "low-density" speech network: one with speech repertoires bonding one friend from another hypothetically in terms of a single relationship among the possibilities of field, kinship, language education, gender, and leisure (Milroy, 1986, p. 20, 139-144). The third network type, figure 15c, is a schematic of a network and its zones (Milroy, 1986, pp. 46-48).

Exhibit F: Relations Between of Questioning and SPEAKING (Figure 16). In keeping with Hymes' $(1974,1986)$ sociolinguistic system, I correlated questions and responses with Hymes' components of 'peech coded mnemonically as SPEAKING. Thus questions 1-135 and variables 1-135 offer heuristic input to description of setting-scene, participant, end or purpose, act sequence, key or style, instrumentality or code, norms of interaction and interpretation, and genre (Hymes, 1986, pp. 58-65). While an imperfect guide, these components are essential and often mark the presence or absence of rules or norms of speaking and thus have a bearing on schools and education.

Exhibit F: Insider-Outsider Protocols (Figure 17). To put it all together systematically, I developed a set of insider-outsider protocols. This schedule of procedures facilitated my entering the speech community and its urban and rural speech fields, linking with networks of speakers tied of language policy and practice in local schools, and assembling data on language and ethnicity for analysis later. 


\section{$\underline{\text { Re-attaching "Back Home" -- Months Later }}$}

While the patterns of language use in speech networks did not crystallize until months later, long after I had completed the interviews and re-attached myself back home, I made discoveries at various stages of data analysis. For example, my experience of entering the speech community revealed two physical settings, urban and rural, and two cultural scenes or identities, Kanadier and Russlaender. My experience of becoming enmeshed in two networks revealed levels of network zones and gatekeepers, and eventually, two speech networks. I found that "friends" in the first order zone or speech community, linked me with "friends-of-friends" in second order zone or speech field. These friends-of-friends, in turn, linked me with "others" in the third order zone or speech network. There, in the third order zone, I discovered two Mennonite speech networks, Kanadier Nerwork and the Russ/aender Network. There, I found evidence of continuity, of conflict, and of compartmentalization in the roles of Mother tongue, God's tongue, and the Queen's tongue in the home, in the congregation, and in the schools. These findings will be discussed in more detail in Chaprer IV.

\section{RE-ENTERING THE MENNONITE SPEECH COMMUNITY: THE SUMMER OF 1990}

All told, from entry to re-entry, I spent twelve months on the ethnography of speaking in the Mennonite speech community. Entering "this world of many codes" during the summer of 1989 , I asked the question Who uses what language with whom, when, where, and why? Reentering during the summer of 1990,1 reconsidered the question $I s$ it possible that the narrower issues of change and cominuity in sidestream ethmicity and langunge reflect the broader issues of shift and constancy in mainstream ethnoculture? Steering at all times between "these two poles of validation" (Hymes, 1980, p. 74), I observed repertoires of English, High German, and/or Low German, patterns of traditional diglossia and modern diglossia, and networks policymakers, educators, and parents linked to language education policy and practice in the Manitoba 
schools. By the end of the sojourn, I authenticated findings by tying my "images" of actual speech acts to speakers' "memories" of key speech events through the process of "feedback" (Bales, 1979, pp. 341-351) or "triangulation" (Goetz \& LeCompte, 1984, pp. 177-178). Afterward, I reflected upon the very existence and character of this "world of many codes . . . and its bearing on schools and education" (Hymes, 1980, pp. 72-77). Given this insideroutsider framework that linked, cut across, and built between the Hymes-type work in the ethnography of speaking, the Milroy-type work in speech networks, and the Bales-type work in multiple fields of interaction to examine the Ferguson-coined phenomenon of diglossia and the Fishman-extended relationship between societal diglossia and individual bilingualism, I turn now to the broad picture of SPEAKING and its bearing on schools. 


\title{
CHAPTER IV
}

\section{A PICTURE OF SPEAKING: \\ DIGLOSSIA AND BILINGUALISM AND THEIR BEARING ON SCHOOLS}

\begin{abstract}
Recognizing that the role of language in schooling draws on deep historical roots and goes through many transformations in modem life, an ethnographer said ...
\end{abstract}

Ethnography is inguiry that begins with recognition that one is at work in situations that are. . . prestructured by the histony and ways of those among whom one inquires. At the heart of it is a process... the interpretation of codes.... the world of inquiry is . . a world of muny codes, of many structures. Not a single natural world, indeed, but a plurality of worlds . . .. This view of ethnography as imguivy imro worlds is a view of these worlds as inherently adapting and changing. recreated and reinterpreted by individuals in their own lifes and in relation to the experience of the group as a whole. ... the existence and character of these worlds, their bearing on schools and educution, can become known only through participarion (pp. 74-77).

Del Hymes (1980)

\section{ORIGINS OF MENNONITE DIGLOSSIA: A DIACHRONIC VIEW OF SPEAKING}

A picture of SPEAKING starts from a diachronic view of Mennonite diglossia and moves to a synchronic or interactive view of Mennonite diglossia and individual bilingualism in a speech communiry, its speech fields, and its speech nerworks. For diglossia (Ferguson, 1959), and societal diglossia and individual bilingualism (Fishman, 1967, 1980), described in Chapter II, marked the particular situation of the Mennonite speech community that emigrated from Russia to Canada. Given the factors that Ferguson said were critical to the origin and 
maintenance of diglossia, namely (a) a sizeable canon in a literary tradition related to a oral tradition, (b) a limited access to literacy, and (c) a suitable period of time after the establishment of (a) and (b), in the order of centuries, I concluded that the language situation in the Mennonite speech community in Manitoba before the 1890 English-only act, could be characterized as a case of stable diglossia. Additionally, given factors that Ferguson called trends toward (1) increased literacy in a standard language, (2) broader communication between groups in society, and (3) widespread desire for a "national" language as a symbol of sovereignty, $I$ found that the diglossic situation in the Mennonite speech community apparently grew unstable after English language rules were imposed in 1890 and German language rights were denied in 1920 . To see this broad picture of SPEAKING, the ethnography looks next at the history of Mennonite dualism and its relation to the literary tradition and an oral tradition in Mennonite speech communities. All of this has a bearing on schools and schooling today.

\section{A Legacy of Mennonite Dualism}

Dualism has marked the Mennonite world-view for at least four centuries (Loewen, 1986). For dualism -- characterized as two traditions of language (an oral tradition and a literary tradition), two views of the world (a secular view and a sacred view), and two fields of social interaction (a prosaic "here and now" and a utopic "hereafter") -- is a legacy Mennonites inherited in 1525, at crossroads in Zurich. There, in an enclave, humanists Erasmus, More, Luther, and Zwingli exchanged ideas of moral philosophy and social reform based on a JudaicHellenic-Christian ideal of paradise. What they envisioned was a "utopia" (Kanter, 1972; Manuel \& Manuel, 1979), a peaceful place where a classical code and a vernacular code separated a utopic world-view from a dystopic world-view.

Neither Catholic nor Protestant nor Jew, these "Anabaptists," as they were called then, meaning "re-baptizers," sought to reshape sixteenth-century institutions, namely the established medieval church-state and the emerging modern nation-state, by advocating a novel idea of 
separation of church and state. In belief, custom, and practice, Anabaptisis objected conscientiously to the convention of brandishing swords, church-state militarism; to the ceremony of swearing oaths, church-state nationalism; and to the act of baptising infants, church-state ritualism. Alternatively, they embraced a communal way of life: a life in harmony with the laws of nature, the lessons of the Old and New Testaments, the catechism of good versus evil, and the norms of the Gemeinde, or "community." To enter and participate in the Gemeinde, adults voluntarily chose instruction in "a straight and narrow path" leading from "this world" to the "other world" then took a vow of adult baptism. That very act came to signify the existence of an Anabaptist dual world and its dual codes.

Labelled "heretics . . . traitors" for their utopic beliefs and, at times, enslaved, banished, persecuted, and executed for their customs and practices, Anabaptists scattered and went underground during the 1520s and 1530s, then re-grouped "a people apart" (Redekop, 1987) in regions outside Swiss borders: the Amish, in Alcase; the Hutterites, in Moravia; and the Mennonites, in Flanders and Frisia (Epp, 1974, 1982; Hostetler, 1974, 1980). Sufferers of repeated atrocities at the hands of church-state inquisitors between the 1550 s and 1650 s, victims of repeated harassments at the hands of nation-state conscriptors after the 1700s, Amish, Hutterites, and Mennonites fled their dystopic conditions and dispersed their movement to different places at different times (Dyck, 1981). Some groups re-settled in regions of Northern Europe and Britain, then migrated to North America during the seventeenth century; others resettled in regions of Eastern Europe, then migrated to North America during the nineteenth and twentieth centuries. All three groups endured and apparently achieved a sense of Gemeinschafi, a sense of identity as a community of people, in Eastern Europe (Urry, 1989) and North America (Kanter, 1972). Today, in addition to the Mennonite community in Manitoba, communities of Anabaptists survive elsewhere in Canada and the United States where they interpret their dual world in dual codes (Anderson, 1988; Anderson 1983; Dyck, 1981; Epp, 
1974, 1982; Hostetler, 1974; 1980). The series of maps in figures 18 through 20 chart the spread of the Anabaptism from Zurich to Northern Europe, Eastern Europe, and Britain, in figure 18; the settlements of Anabaptist-Mennonites in Russia, in figure 19; and the movements and settlements of Mennonites in North America, in figure 20.

\section{A Literary Tradition and an Oral Tradition}

The literary tradition and the oral tradition of the first Mennonite communities in Manitoba, then, was derived from the first Mennonite communities in Flanders and Frisia, and from the language of their founding patriarch Menno Simons. Their literary tradition was based an particular ideology about separation of church and state, described above, and included Simons' religious tracts in a variety of Anglo-Frisian before the 1550 s, his religious treatises in a variety of Netherlandic-Germanic after the 1550s, and the Anabaptist canon in Luther High German after the 1750s (R. Epp, 1987; J. Loewen, 1986). Representative works included the Schleitheim Confession (1527), the The Complete Writings: of Memo Simons (c1530), the Ausbund (1564), the Dortrecht Confession (1632), and the Martyrs Mirror (1660) (Dyck, 1981, pp. 31-37, 56-63, 132-151; Hustetler, 1980, 21-29, 34-35, 225-229; C. Redekop, 1989, pp. 329, 47-60). Additionally, this literary tradition related linguistically to the oral tradition of Plautdietsch spoken first in the Danzig, Marienburg, and Elbing regions of Prussia, later in the Molotschna and Chortitza regions of Russia, and in the last century on the East and West reserves of Manitoba. For both the literary tradition in Dutch and Luther High Germas and the oral tradition in regional varieties of Plautdietsch originated in the West Germanic branch of the Proto-indo-European family of languages (Pyles \& Algeo, 1982, pp. 70-71).

So the Mennonites who emigrated from Russia to Canada during the 1870 s and 1880 s, described in Chapter I, shared a history and a way of speaking with Mennonite communities in Flanders and Frisia in the 1550s, described here. Given this legacy of dualism and its relation to the literary and oral traditions, I concluded that the language situation of Mennonites in 


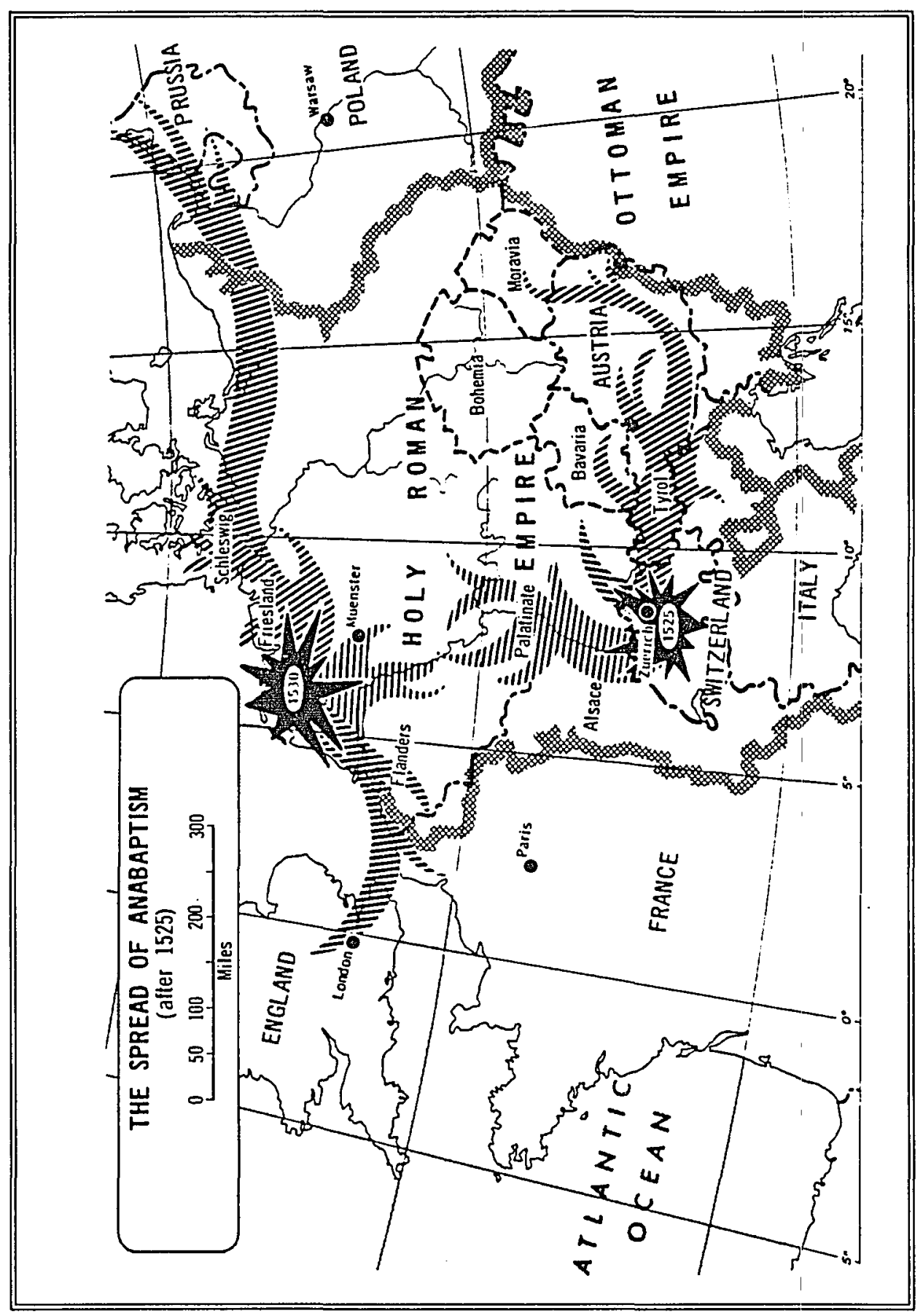

Figure 18. Anabaptist movement in Europe. A map of Europe shows the rise of Anabaptism in Zurich and its spread to Northern and Eastern Europe during the sixteenth century. Source: Epp (1974, p. 31). 


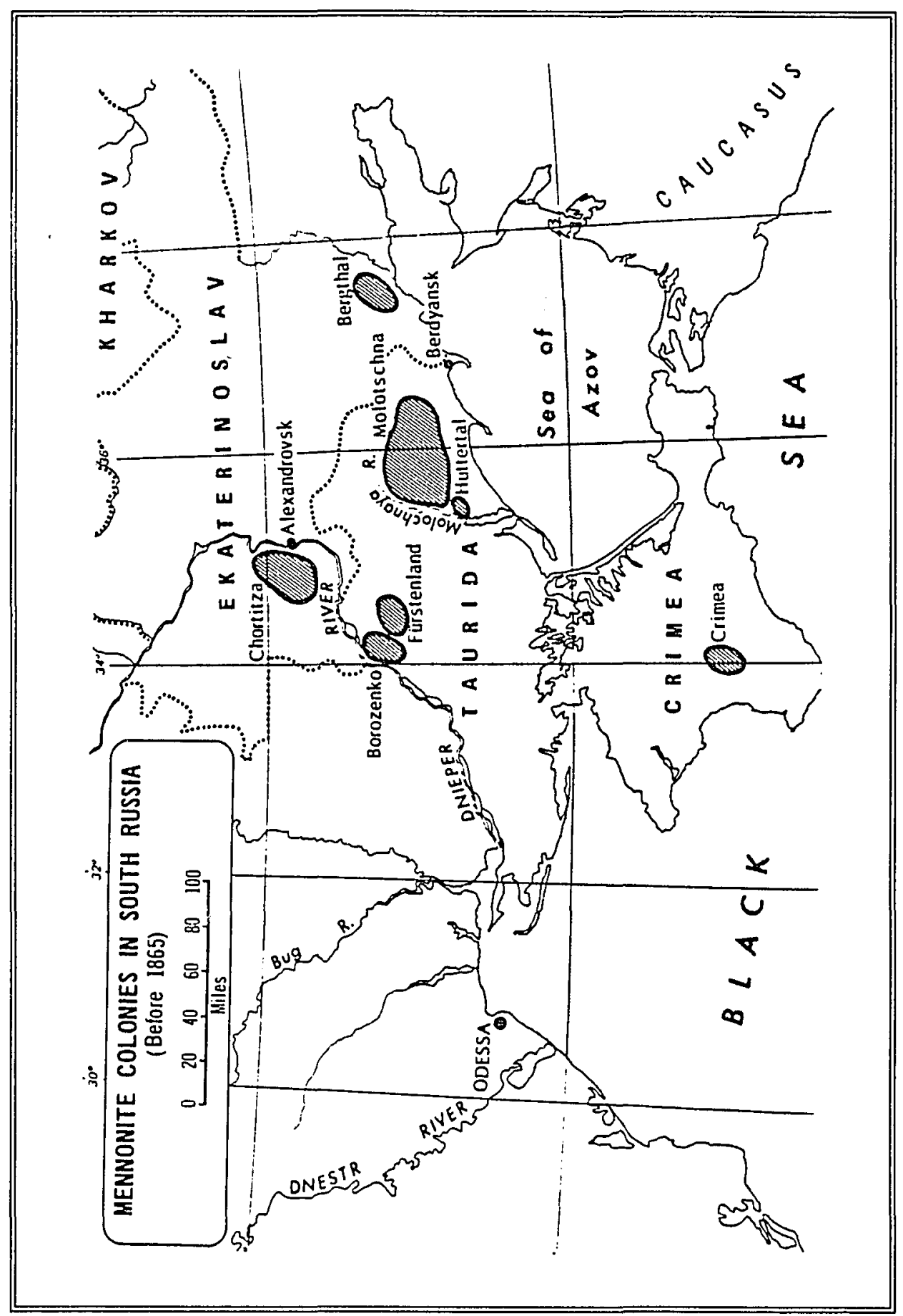

Figure 19. Mennonite settlement in Eastern Europe. A map of

Mennonite colonies in Russia, in the 1800s, shows locations of the

Chortitza and Molotschna colonies and their proximity to other colonies.

Source: Epp (1974, p. 162). 


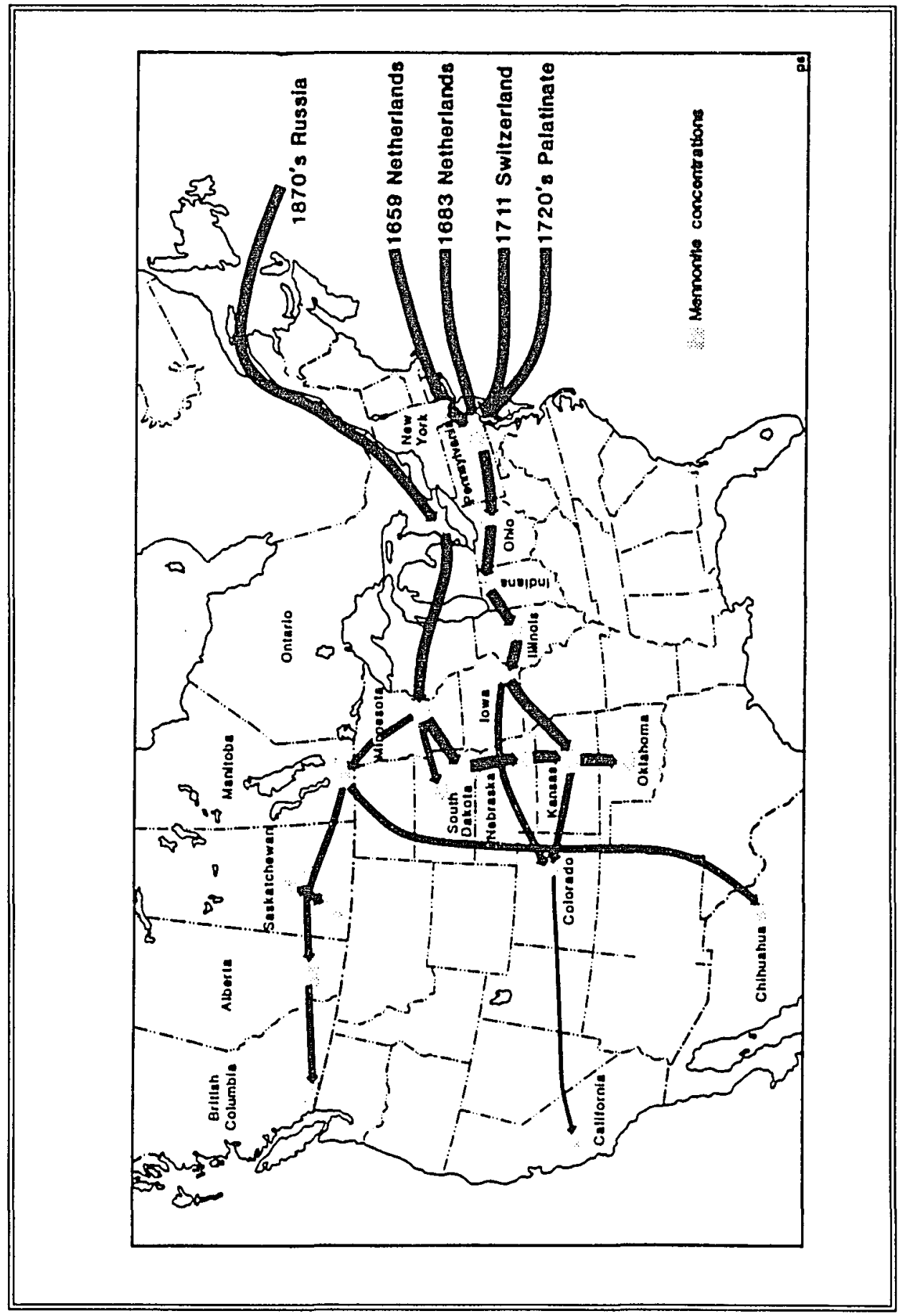

Figure 20. Mennonite settlement in North America. A map of Mennonite migration to North America, between the 1650 s and the 1870 s, shows sites where Mennonites settled in Canada and the United States. Source: Redekop (1989, p. 18). 
Manitoba fulfilled Ferguson's (1959) "linguistic relatedness" criterion that subsumed the descriptive "rubrics" of grammar, lexicon, and phonology, and his "function" criterion that subsumed the descriptive rubrics of function, prestige, acquisition, standardization, literary heritage, stability (Britto, 1986, 99. 9-26; Ferguson, 1959, pp. 328-336).

Linguistic Relatedness. Clearly, the literary and oral traditions of the Mennonite speech community in Manitoba satisfied Ferguson's (1959) criterion of linguistic relatedness. Further, given R. Epp's (1987) and Goertzen's (1970) studies, and others' as well, both the H and the L, two varieties of German, showed relationships in phonology, grammar, and lexicon (Rempel, 1984; Thiessen, 1977). First, while the range of sounds differed between $\mathrm{H}$ and $\mathrm{L}$, and across communities, the derivations of sound and the ways of combining sounds were based on the same phonology system. Second, while the inflections of nouns and verbs differed between $\mathrm{H}$ and $\mathrm{L}$, and the syntax of clauses differed, the ways of combining structures were based on the same grammar system. And third, while $\mathrm{H}$ was a written tradition and $\mathrm{L}$ was a spoken language, some borrowing and mixing occurred in both varieties. In the case of $L$, for example, migration and settlement patterns brought speakers of Pluutdietsch in contact with different spoken varieties in Frisia, Prussia, Russia, and Canadia between the 1550s and the 1890s. Gradually, words from Dutch, Polish, Russian, and English became part of the lexicon. In the case of $\mathrm{H}$, for another example, migration and settlement pattems brought users of Hochdeutsche in contact with different written varieties of a stindard "national" language as an attribute of sovereignty. Canadian language policy and Manitoba educational policy, between 1890 and 1969, superposed English as the standard national language on the Mennonite speech community. Policies in 1969, 1982, and 1988 have superposed "Multiculturalism Within a Bilingual Framework" as the standard. The relationship between $\mathrm{H}$ and $\mathrm{L}$ has changed.

Function. The literary and oral traditions of the Mennonite speech community satisfied Ferguson's (1959) criterion of "function." For two varieties of the same language, on 
$\mathrm{H}$ and one $\mathrm{L}$, existed "side by side throughout a community, with each having a definite role to play" (Ferguson, 1959, p. 335). This relationship between language form and social function subsumed the features of acquisition, standardization, prestige, literary heritage, and stability (Britto, 1986, pp. 8-26). Under the rubric of acquisition, $L$ was learned naturally at home as a mother tongue and used to speak with children, parents, hired help, and the uneducated. Virtually all the speakers in this study reported that the $L$ functioned as the language of hearth and home, simple economies, and bawdy conversations (Journal, 1989). The H, on the other hand, was learned later as a language of instruction in private schools and used to read, write, and recite the catechism (Journal, 1989). The $\mathrm{H}$ functioned as the language of the meetinghouse and the schoolhouse (Journal, 1989). Under the rubrics of standardization and prestige, $\mathrm{H}$ had a strong tradition preserved in a variety of genre including sermons, doctrines, hymnals, journals, epics, as well as grammars, dictionaries, orthographies, and style books. This heritage linked the written tradition to an ideology of an earlier period and a distant place. The educated elite who used $\mathrm{H}$ regarded it as more beautiful, more poetic, more expressive of important thoughts than $L$. Until recently, no comparable process of standardization was undertaken with $L$ (Klassen, 1989; Reimer, 1983). As a whole, the community as a whole regarded $L$ as an inferior language, and in some situations as no language at all (Journal, 1989). Canadian language policy and Manitoba educational policy, between 1890 and 1969, superposed English as the second H on the German H and L. Policies in 1969, 1982, and 1988 have superposed "Multiculturalism Within a Bilingual Framework" on ethnic language. As the next major section shows, the functions of $\mathrm{H}$ and $\mathrm{L}$ have changed: function is user-oriented rather than useoriented.

\section{From a Diachronic View to a Synchronic View}

Trends toward English-only in Canada after 1890, posed a very real threat to this legacy of dualism and to its literary and oral traditions. Indeed, the speech act in a Mennonite 
private school around 1890, and the words, in German, "What! English? My children shall not! . . . That shows the new spirit . . . That is the beginning of the end" (Epp, 1974), illustrated an historical problem and an enduring question of ethnic language in Anglo-American schooling. To see more of the broad picture of SPEAKING, the ethnography moves from this diachronic view of the past to a synchronic view of the present.

\section{INTERACTION OF SOCIETAL DIGLOSSIA AND INDIVIDUAL BILINGUALISM: A SYNCHRONIC VIEW OF SPEAKING}

A picture of SPEAKING moves to a synchronic view or inleractive view of Mennonite diglossia and individual bilingualism. Given the relationships that Fishman (Fishman, 1967, 1980) said are likely to occur between diglossia, defined as "an enduring societal arrangement extending at least beyond the third generation," and bilingualism, defined as an individual "asset or debit," I concluded that the strict compartmentalized language situation of the past had given way to a fluid language situation today. Additionally, given these factors, I assumed that the processes of interaction and change were underway in the Mennonite speech community. Indeed, I found evidence of the interactive diglossic situation in the primary settings of the home, the congregation, and the school: namely, (1) diglossia with bilingualism, (2) diglossia without bilingualism, (3) bilingualism without diglossia, and (4) neither bilingualism nor diglossia. Dodson (1989) summed it all up: "Bilingualism without diglossia is a transitory situation leading inevitably to unstable bilingualism and, eventually to monolingualism" (p. 387). The evidence for these conclusions is illustrated and explained in the sections on codechoosing and code-switching next.

Interaction of Mennonite Diglossia and Individual Bilingualism

To see this picture of SPEAKING, the ethnography continues here a description of relationships between Mennonite diglossia and individual bilingualism as told by fifty-seven 
speakers during the summers of 1989 and 1990. Throughout the inquiry, I gave particular attention to the pre-existing scales of speech community, speech field, and speech network described in Chapter II (Hymes, 1986) and applied to this study in Chapter III. I selected these fifty-seven speakers because they had come in contact with "One Language, One Language, One School" policies enacted between 1890 and 1920, and in effect in local schools through 1970, and/or because they had come in contact with "Multiculturalism Within a Bilingual Framework" policies enacted between 1970 and 1988, and in effect in local schools today. Once I selected the speakers to interview, I approached the insider-outsider interview as a "friend-of-a-friend" and treated the exchange of questions and the responses systematically as a sequence of speech acts and speech events related to the components of SPEAKING. The methods and instruments of the exchange are described and exhibited in Chapter III. To see particular patterns of codechoosing and code-mixing, I analyzed the data exhibited in Appendices A through $\mathrm{F}$ and looked for relationships between the social variables and language variables below.

Social Variables. All fifty-seven speakers were directly or indirectly associated with the Manitoba system of public schools or the Mennonite system of private schools. The description of who they are and how they became linked in networks tied to educational policy and practice begins with summaries below of eight social variables: (a) age of speaker, (b) sex of speaker and age, (c) local setting of speaker, (d) education of speaker, (e) occupation of speaker, (f) ethnicity of speaker, and (g) identity of speaker, and (h) network index of speaker. I selected these variables from the chart of language and social variables located in Appendix A (specifically, variables labelled Q1, Q2, Q3, Q32 and Q39, Q25, Q7, Q10, and Q82, respectively).

(a) Age of Speaker. Fifty-seven speakers ranged in age from 25 to 74 years; four were in their 20s; fourteen were in their 30s; twenty in their 40s; nine were in their 50s; eight were in their $60 \mathrm{~s}$; and two in their 70 s. The median age was 45 ; the mean age was 46 . 
(b) Sex of Speaker and Age. Twenty-two female speakers ranged in age from 25 to 74 years; three were in their 20s; seven were in their 30s; eight were in their 40s; three were in their $60 \mathrm{~s}$; and one was in her 70s. The median age was 40 ; the mean age was 42 . Thirty-five males speakers range in age from 26 to 74 years; one was in his 20s; seven were in their 30s; twelve were in their 40s; nine were in their 50s; five were in their 60s; and one was in his 70s.

(c) Setting of Speaker. Thirty-seven speakers lived and/or worked in the urban speech field defined as Kildonan on the North End of Winnipeg and selected settings in greater Winnipeg. Thirty of these speakers in the urban field met and participated in the insideroutsider interviews in ethnic settings and scenes including the Centre for MB Studies in Canada, the Mennonite Heritage Centre, the Mennonite Studies Centre at the University of Winnipeg, and private residences. Twenty speakers lived and/or worked in the rural speech field defined as the East Mennonite Reserve located approximately 50 kilometers southeast of Winnipeg, and the West Mennonite Reserve located approximately 100 kilometers southwest of Winnipeg. Eighteen of these speakers in the rural field met and participited in the insider-outsider interviews in ethnic settings and scenes including the Mennonite Heritage Village and private residences. Public settings included the Manitoba Department of Education, the River East School Division in the urban speech field, and the Hanover/School, Garden Valley, and Rhineland school divisions in the rural speech field. Local /scenes shifted from schools and libraries, to offices and restaurants, to residences and parks, depending on "ethno-acts and ethno-events" and other components of SPEAKING.

(d) Education of Speaker. Forty-six of the speakers received their education either in private Mennonite schools or in public schools serving the local Mennonite population. Seven speakers finished high school; two received an associate's clertificate; thirty-three received a bachelor's degree; five received a master's degree; and ten held doctoral degrees. While the observation can be made that the level of education is high for a "representative" group of 
speakers, the observation can also be made that the speakers are "educators" thus "educated." Further, the fact is that forty speakers reported that they were the first in their families to receive an education beyond the primary grades. They may indeed be representative of a modern Mennonite speech community.

(e) Occupation of Speaker. Thirty-eight speakers were professional educators tied directly to language education policy, practice, and promotion; six speakers were students working toward advanced degrees in language and language education; of the six, two worked part-time as language instructors. The remaining thirteen speakers were parents active in the local school community; two were skilled workers; one was a clerical worker; seven were farmers or homemakers; three were technicians.

(f) Ethnicity of Speaker. Forty-eight speakers were ethnic "Mennonites" who share rules for the conduct and interpretation of codes of the traditional pattern of Mennonite diglossia -- two varieties of German, one $\mathrm{H}$ and one $\mathrm{L}$-- or rules for the conduct and interpretation of codes of the modern pattern of Mennonite diglossia -- a Canadian variety of English and two varieties of German, or two Hs and one L. Additionally, three Mennonites who returned from Mexico reported use of Spanish; one who returned from Brazil reported use of Portuguese; and six recent Russian-Mennonite immigrants reported use of Russiian. Nine speakers were "nonMennonites" who share rules for the conduct and interpretation of other codes. All nine spoke a Canadian variety of English; six spoke a German variety of High German; one spoke a northern variety of Italian; and one spoke a Canadian variety of French.

(g) Identity of Speaker. Twenty-six ethnic Mennonites identified with the first wave of Russian-Mennonite immigrants, the Kanadier who first settled on the East Reserve and West Reserve in the 1870s and 1880s; ten were second-generation Canadians, and sixteen thirdgeneration Canadians. Twenty-two ethnic Mennonites identified with the second and third wave of Russian-Mennonite immigrants, represented here as the Russlitender, who generally settled on 
the North End after the 1920s; eleven were immigrants, seven were first-generation Canadians, and four were second-generation Canadians. Six non-Mennonites identified with mainstream German heritage; three were immigrants, and three were first-generation Canadians. Three claimed other heritages.

(h) Network Index. Milroy (1986) noted linguistic enforcement mechanisms in the context of speech networks. As discussed earlier in Chapter III, she concluded that conditions of network membership, namely, (1) neighborhood ties, (2) kinship ties, (3) place of work/school ties, (4) gender ties, and (5) voluntary leisure time ties, contributed to the maintenance of speech in networks. In keeping with Milroy's (1986), I assigned one point for each of the following conditions a speaker fulfilled: (1) membership tie to Mennonite community by virtue of a residence and/or local school located in the urban and rural speech fields; (2) claim to both kinship and family ties to Anabaptist-Mennonite tradition of the speech community; (3) professional, elected, or voluntary tie to language education policy, practice, or promotion of English-German bilingual studies or Low German studies in public schools or private schools; (4) gender relationship to condition (3); and (5) voluntary and leisure relationship to conditions (3) and (4). The score, then was a measure of network density. Seven speakers scored one on the network index; four scored two; six scored three; eleven scored four; and twenty-nine scored five. Speakers with a score of five, or with a network density of 100 percent, became the object of close analysis to observe code-choosing and code-mixing where enforcement mechanisms apparently were in tact.

Language Variables. The description of language begins with what fifty-seven speakers said about their use of four variables of language: English (E), High German (HG), and Low German (LG) in the primary settings of the home, the meetinghouse, and the schoolhouse, and French $(F)$ generally. The description further includes reports of language use at two times in speakers' lives, the past and the present. Given the time of the study and the ages of the 
speakers, past is defined as what speakers said about the codes of their homes, their congregations, and their schools in the community of their childhood, a span of time between 1920 and 1970, when English-only prevailed in the schoolhouse. Present is defined as what speakers said about the codes of their homes, their congregations, and their schools in the community of their livelihood, a moment in the summer of 1989 , when "language choice" prevailed in the schoolhouse. I selected these language variables from the chart of language and social variables located in Appendix A (specifically, variables labelled Q40, Q68, Q54 as codes of the past, and Q92, 107, and Q114 as codes of the present). Additionally, I summarized the distributions of these language variables within the ethnic Mennonite speech community and speech fields. Data summaries are located in Appendix C. The description continues with a discussion of six profiles of code-choosing and code mixing as they occurred in the ethnic Mennonite speech community, urban and rural speech fields, and its speech networks.

\section{Profiles of Code-Choosing and Code-Mixing -- Past and Present}

Profiles of code-choosing and code-mixing, past and present, depict the inherently interacting and changing character of Mennonite diglossia and individual bilingualism at the scales of speech community, speech field, and speech network. Starting from English (E), High German (HG), Low German (LG), and French (F) as variables of language, I made distinctions between ethnic Mennonite speakers and non-Mennonite speakers, between urban and rural settings, and between Kanadier and Russlaender repertoires as variables of ethnicity. I displayed the distinctions between these ethnolinguistic variables in the primary settings and scenes of home, meetinghouse, and schoolhouse. Additionally, I presented these ethnolinguistic variables at two times, past and present. Altogether, then, six profiles, illustrated as figures 21 through 26, depicts the interactive field of Mennonite diglossia and individual hilingualism depicts two profiles of the urban and rural speech fields, past and present, in figures 21 and 22; two profiles of Kanadier and Russlaender repertoires, past and present, figures 23 and 24; and two profiles 


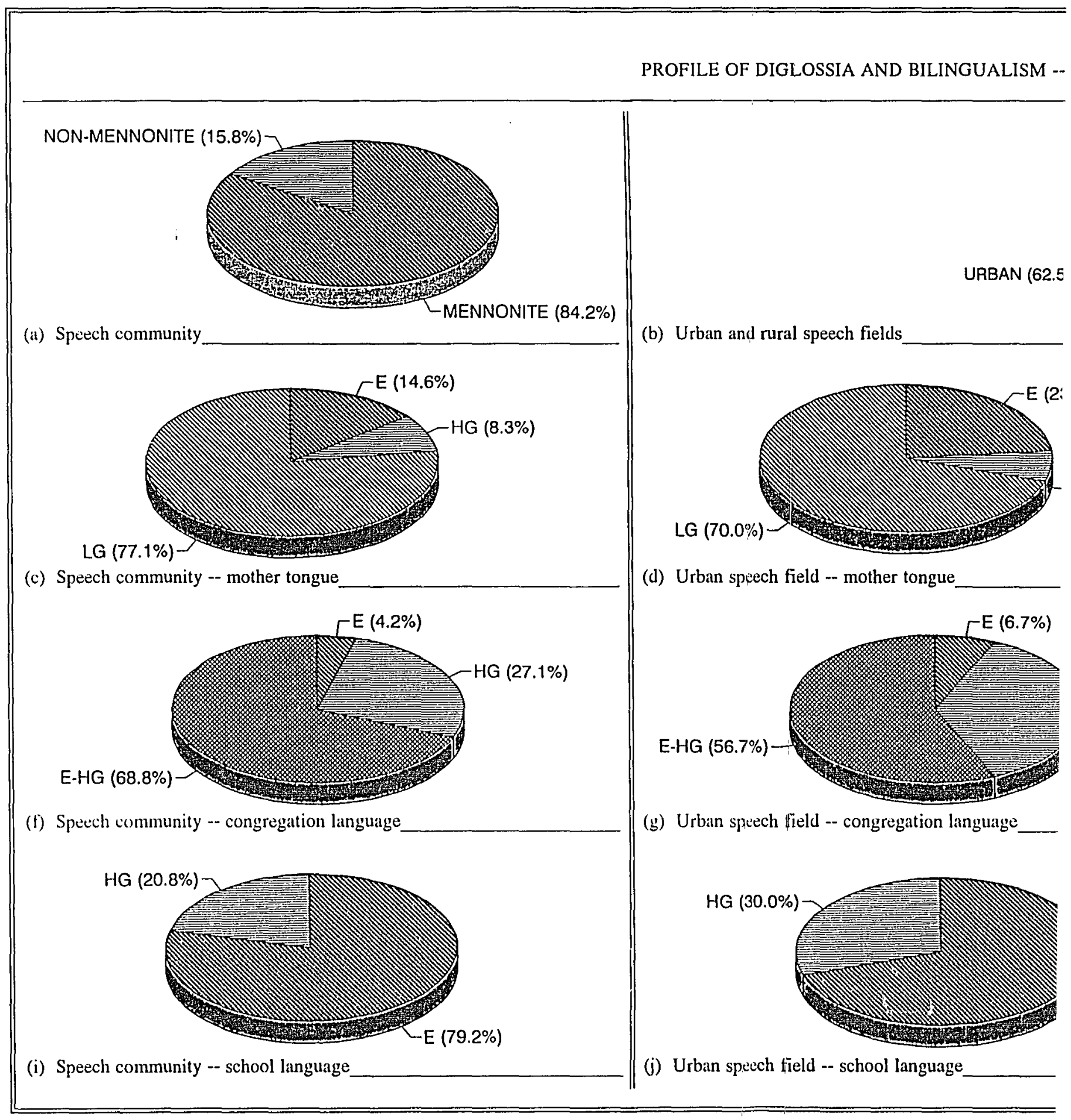

Figure 21. Profile of diglossia and bilingualis 
$-$ 


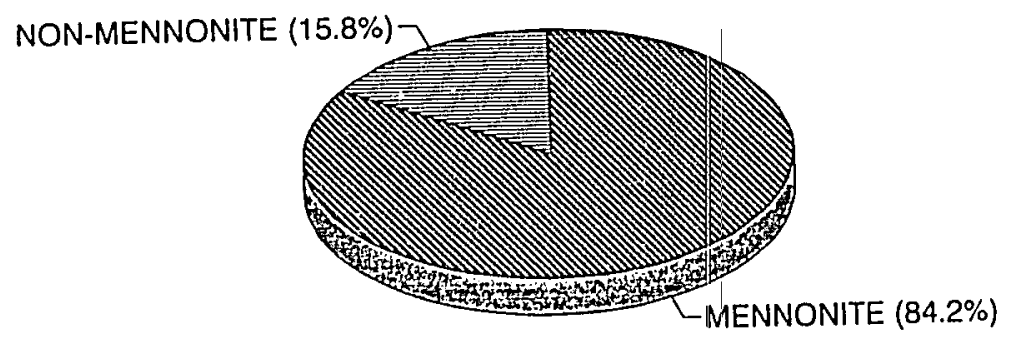

(a) Speech community

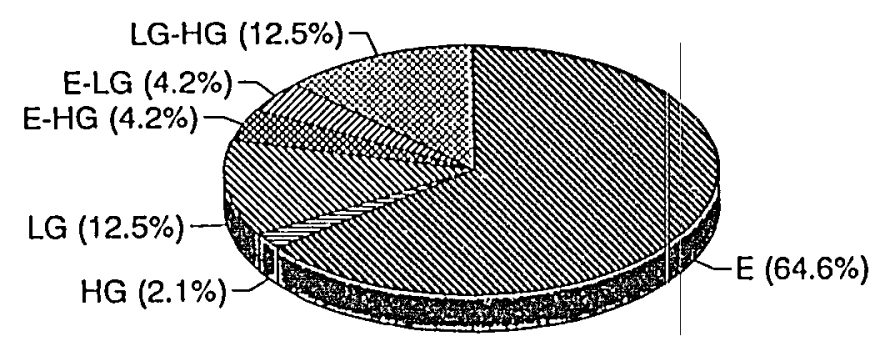

(c) Speech community -- home language

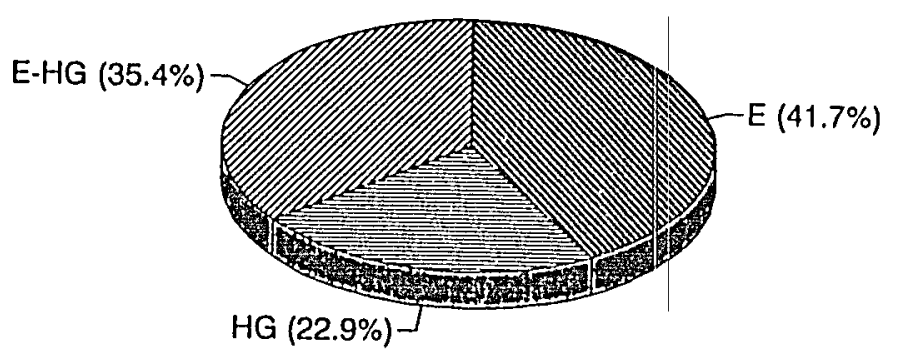

(f) Speech community -- congregation language

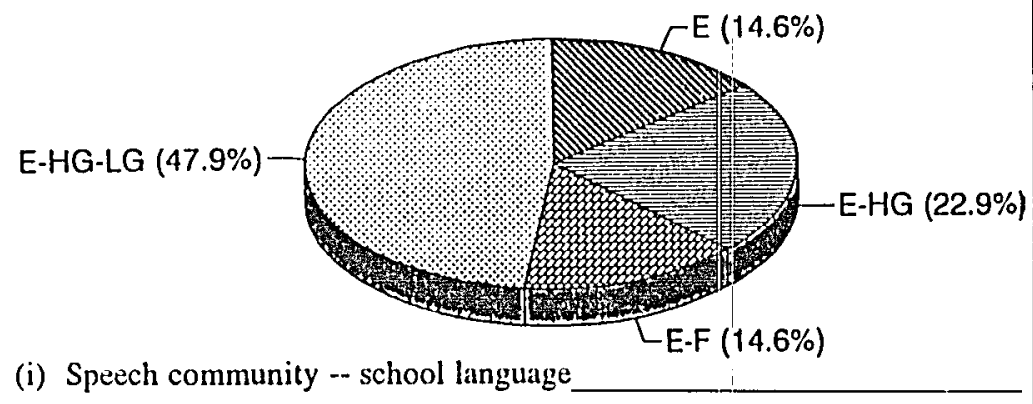

(b) Urban and rural speech fields

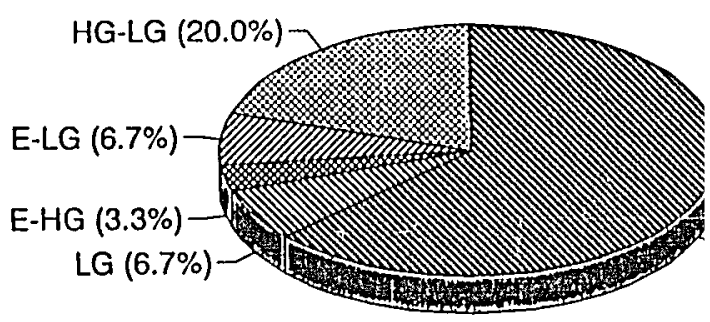

(d) Urban speech field -- home language

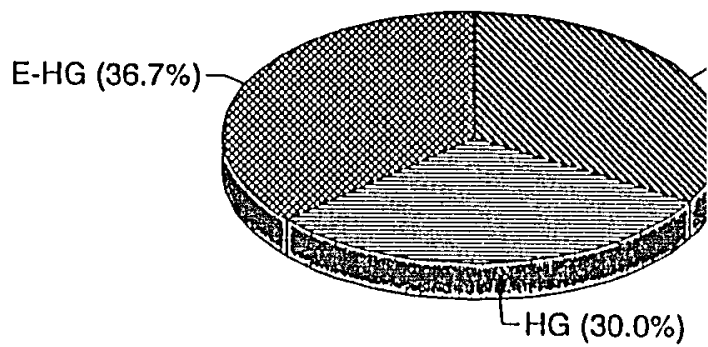

(g) Urban speech field -- congregation language

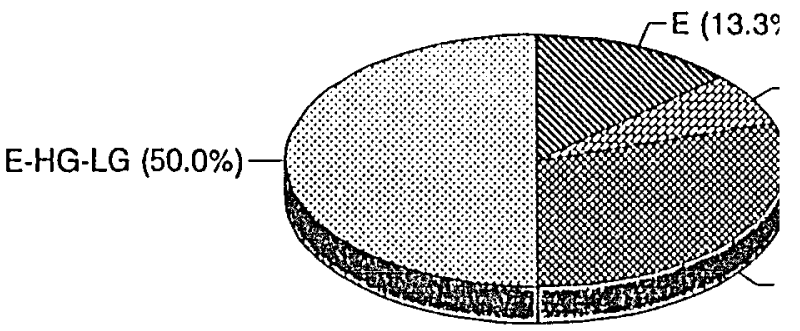

(j) Urban speech field -- school language

Figure 22. Profile of diglossia and bilingualism -- pre: 

URBAN $(62.5 \%)$

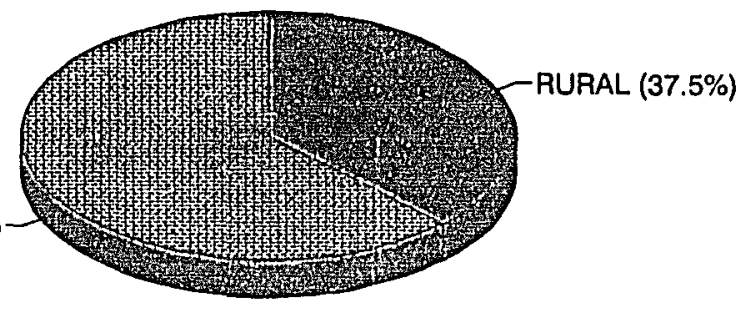

sch fields

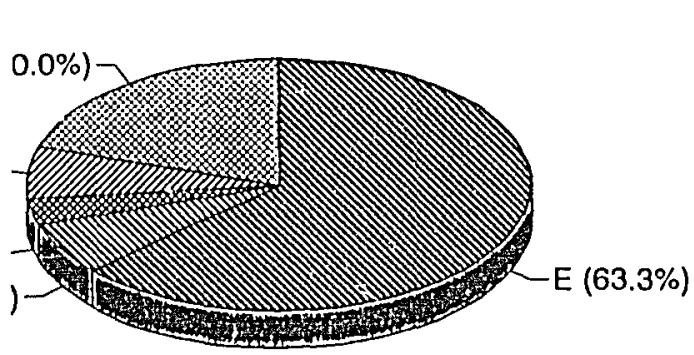

- home language

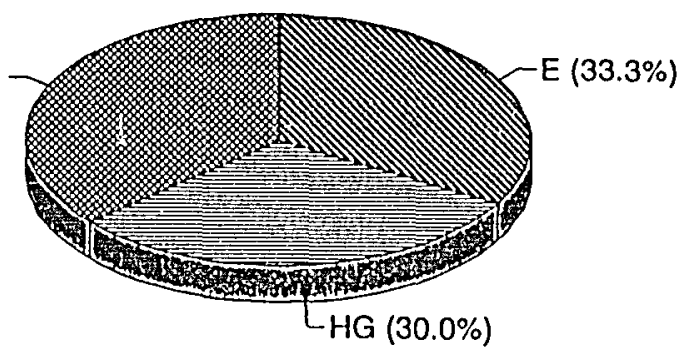

-- congregation language

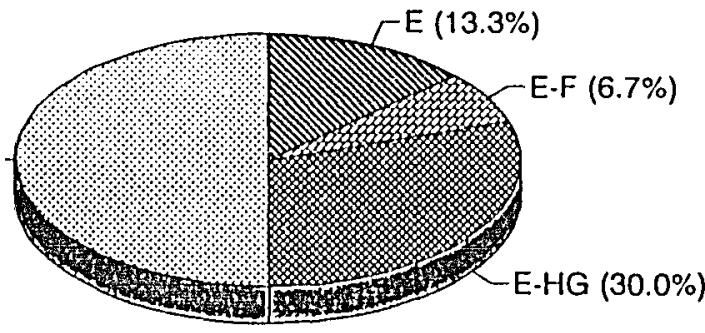

- school language

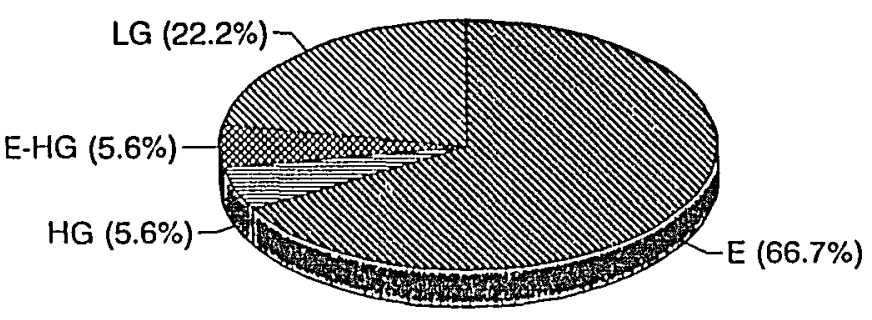

(e) Rural speech field -- home language

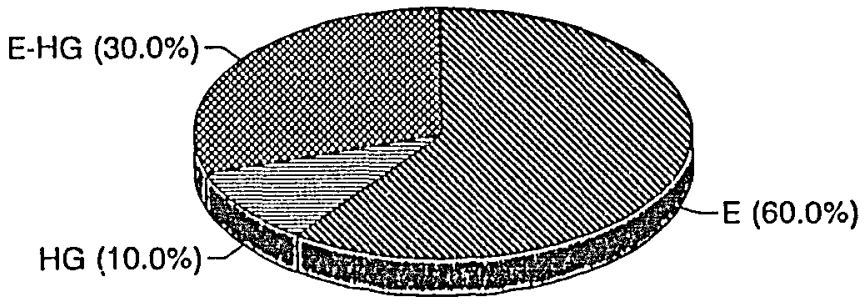

(h) Rural speech field -- congregation language

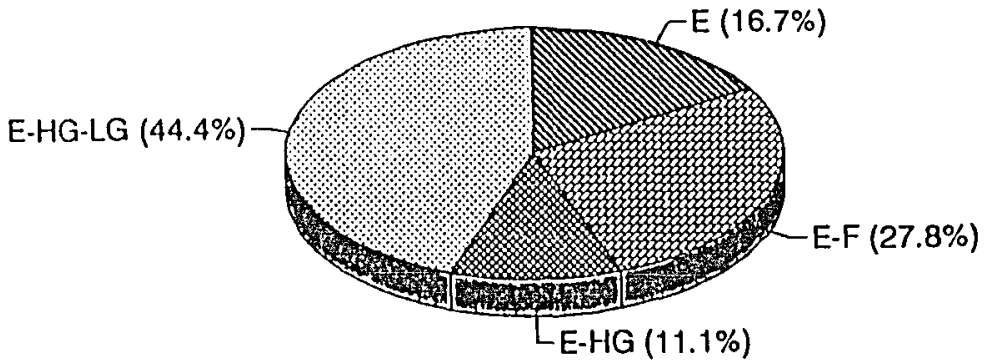

(k) Rural speech field -- school language

le of diglossia and bilingualism -- present. 



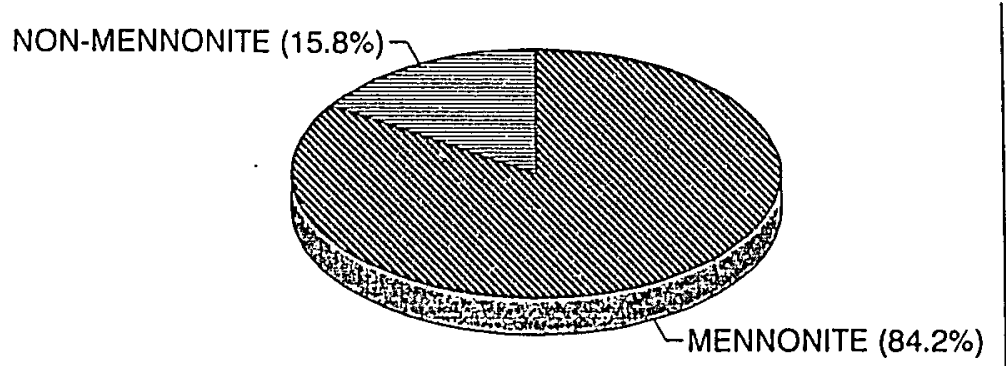

(a) Speech community

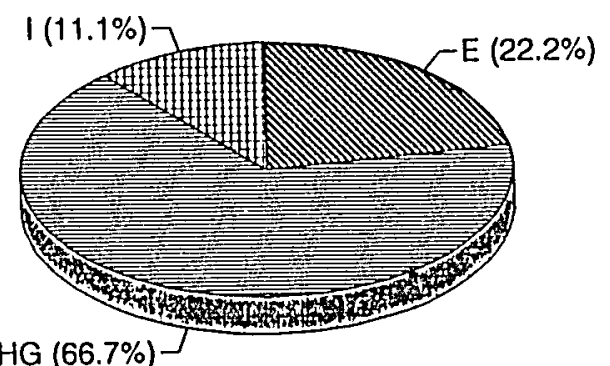

(c) Non-Mennonite repertoire -- mother tongue

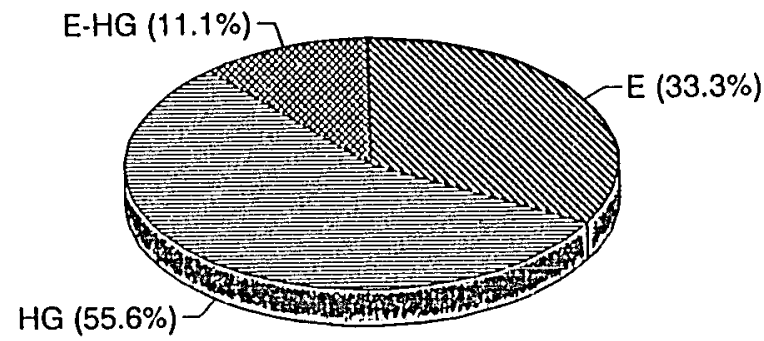

(f) Non-Mennonite repertoire -- congregation language

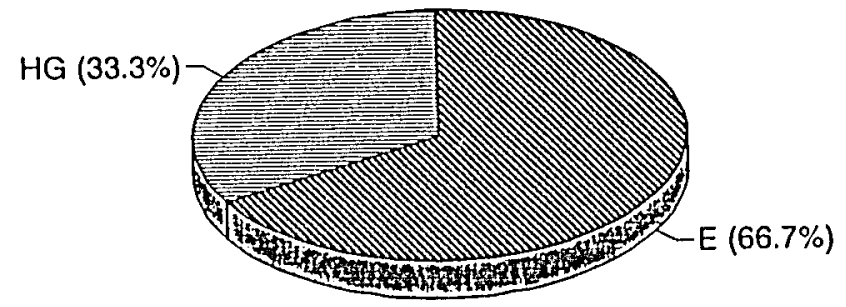

(i) Non-Mennonite repertoire -- school language
RUSSLANDER (45.8\%)

(b) Russlaender and Kanadier speech repertoires

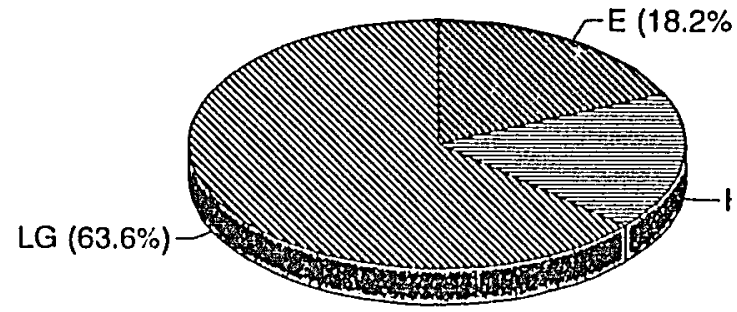

(d) Russlaender speech repertoire -- mother tongue

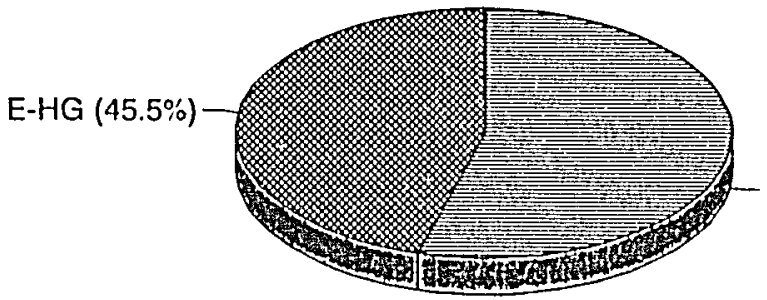

(g) Russlaender speech repertoire -- congregation language.

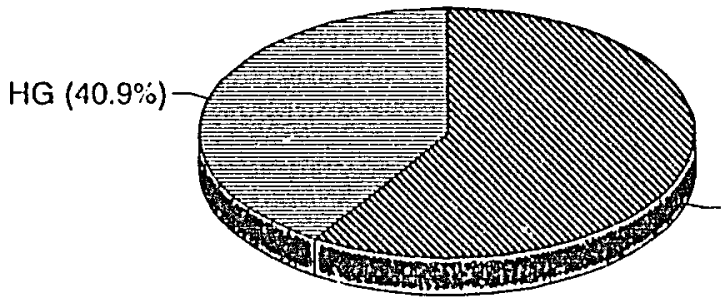

(j) Russlaender speech repertoire -- school language

Figure 23. Profile of repertoires -- past. 


NON-MENNONITE (15.8\%)-

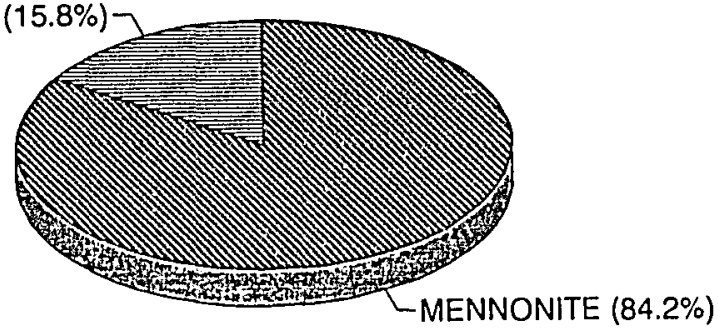

(a) Speech community

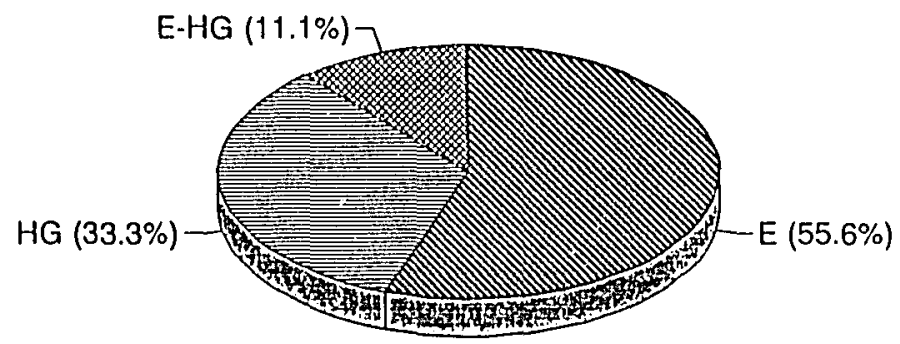

(c) Non-Mennonite repertoire -- home language

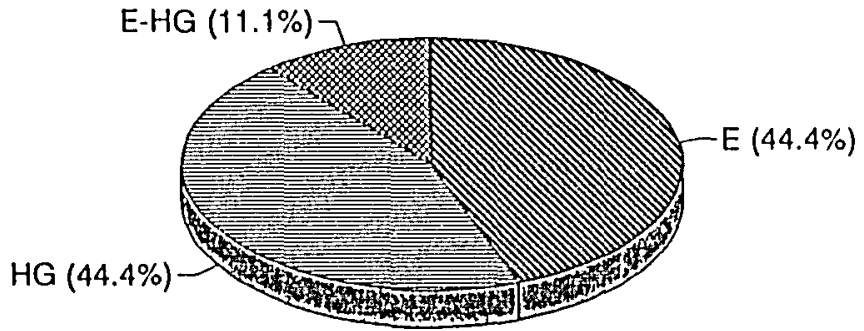

(f) Non-Mennonite repertoire -- congregation language

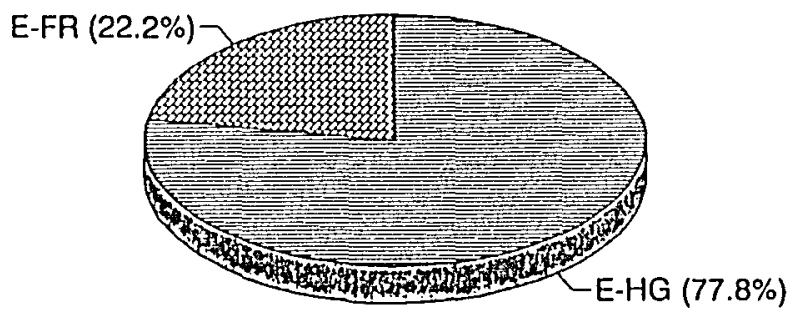

(i) Non-Mennonite repertoire -- school language
RUSSLAENDER (45.8\%)-

(b) Russlaender and Kanadier speech repertoires

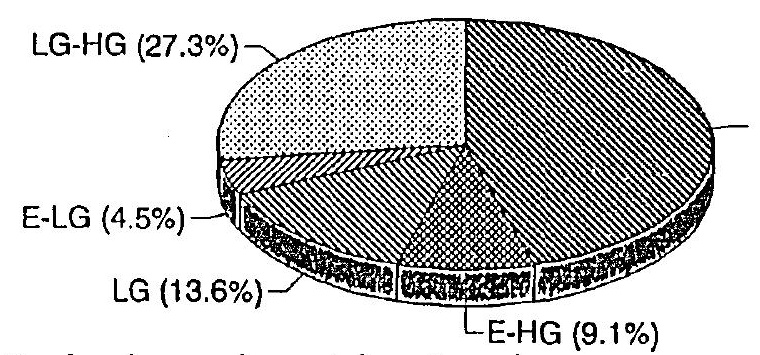

(d) Russlaender speech repertcire -- home language

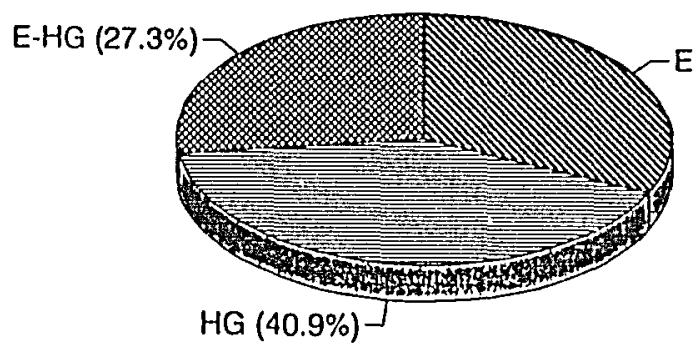

(g) Russlaender speech repertoire -- congregation language_

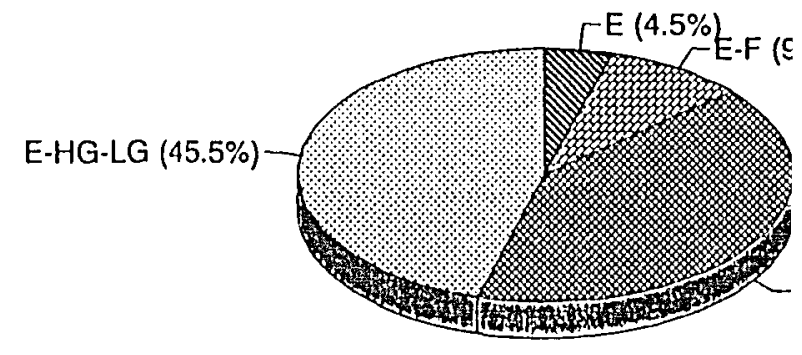

(j) Russlaender speech repertoire -- school language

Figure 24. Profile of repertoires -- present. 


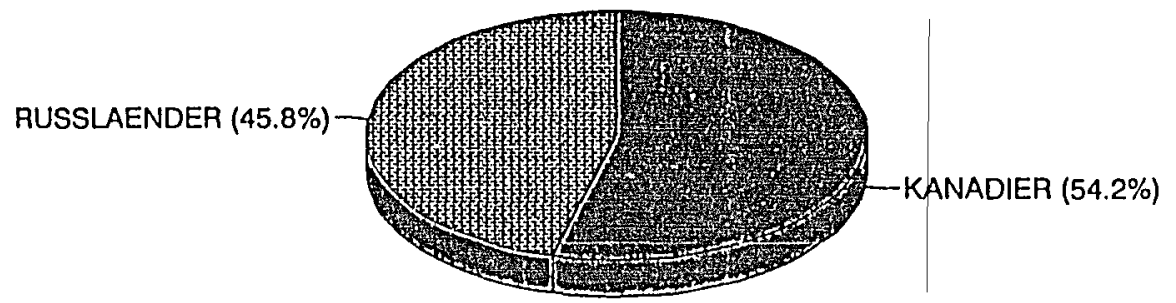

anadier speech repertoires

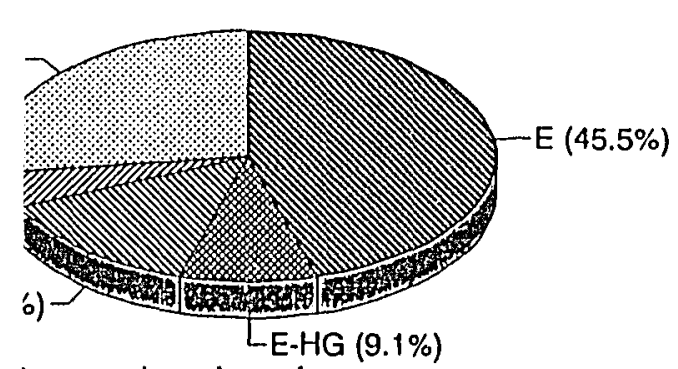

h repertoire -- home language

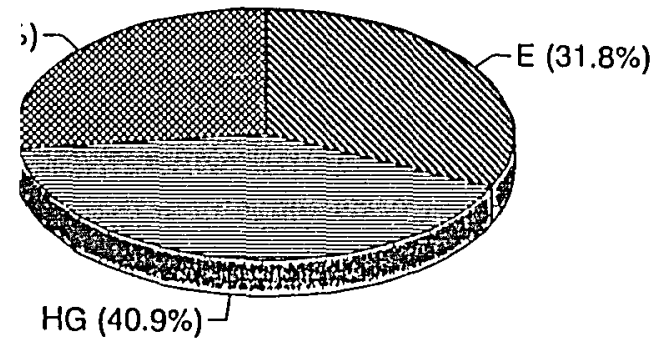

h repertoire -- congregation language

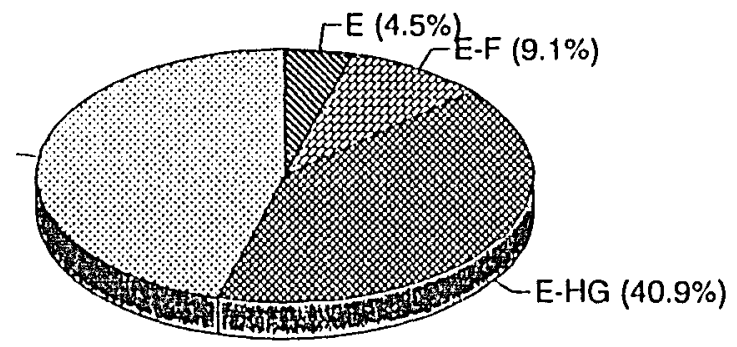

h repertoire -- school language

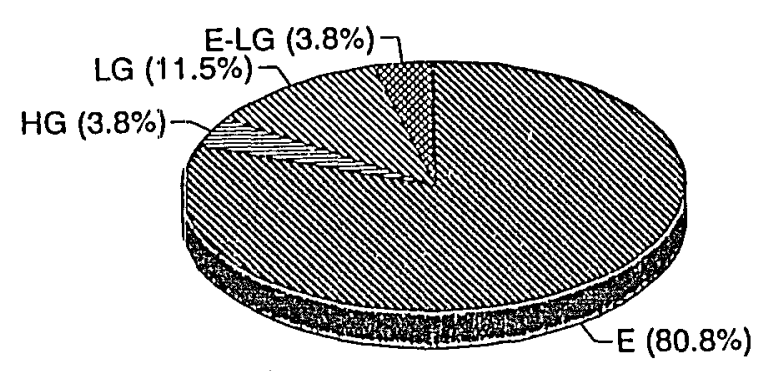

(e) Kanadier speech repertoire -- home language

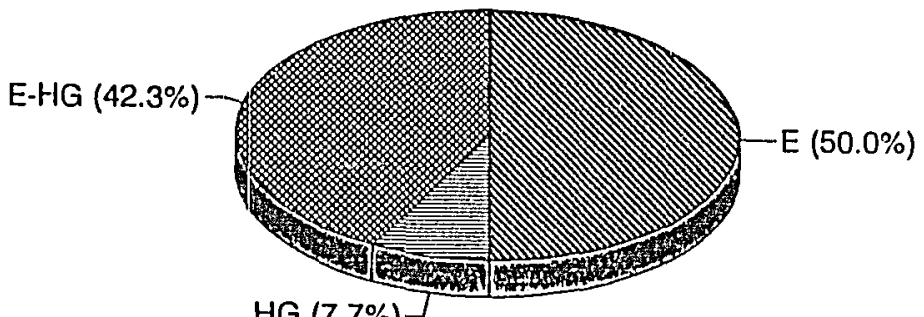

HG $(7.7 \%)$

(h) Kanadier speech repertoire -- congregation language

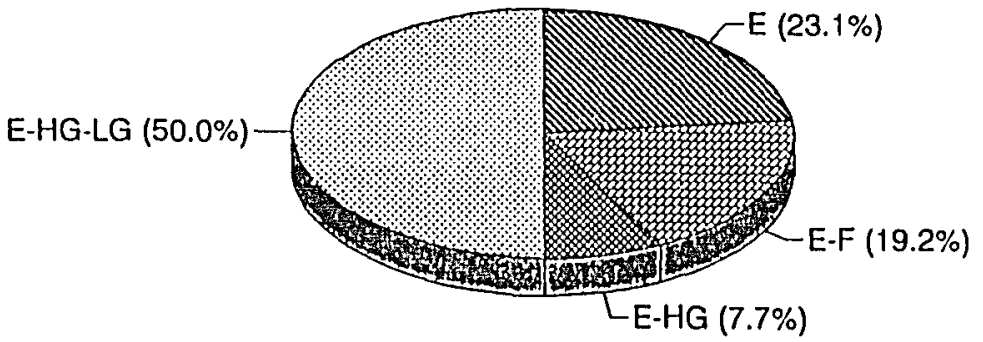

(k) Kanadier speech repertoire -- school language

ofile of repertoires -- present. 



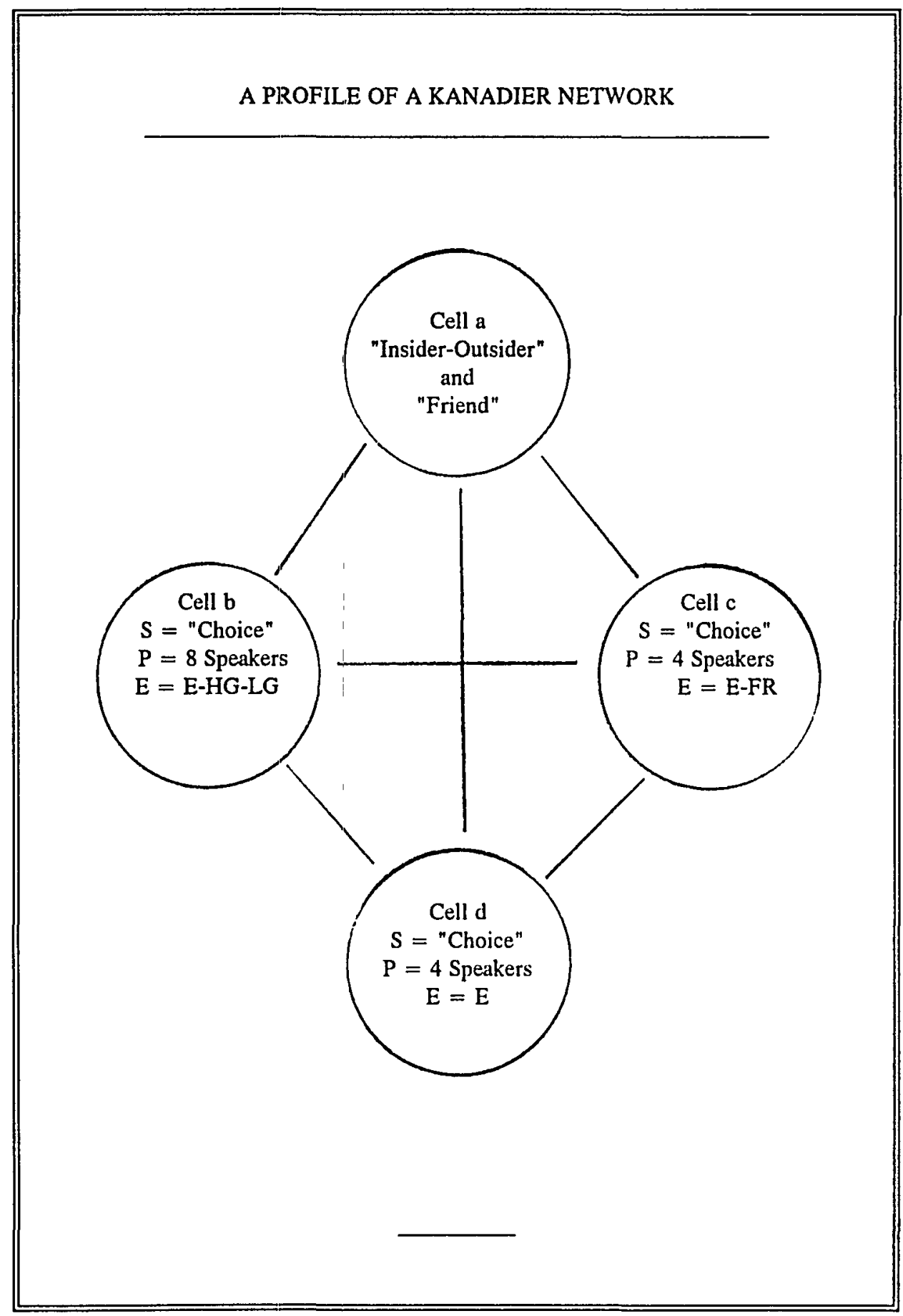

Figure 25. A profile of a Kanadier Network. A portion of the Kanadier Network with 100 percent density shows repertoires and language education "choice" or ends as reported by sixteen speakers. Source: Joumal (1989). 


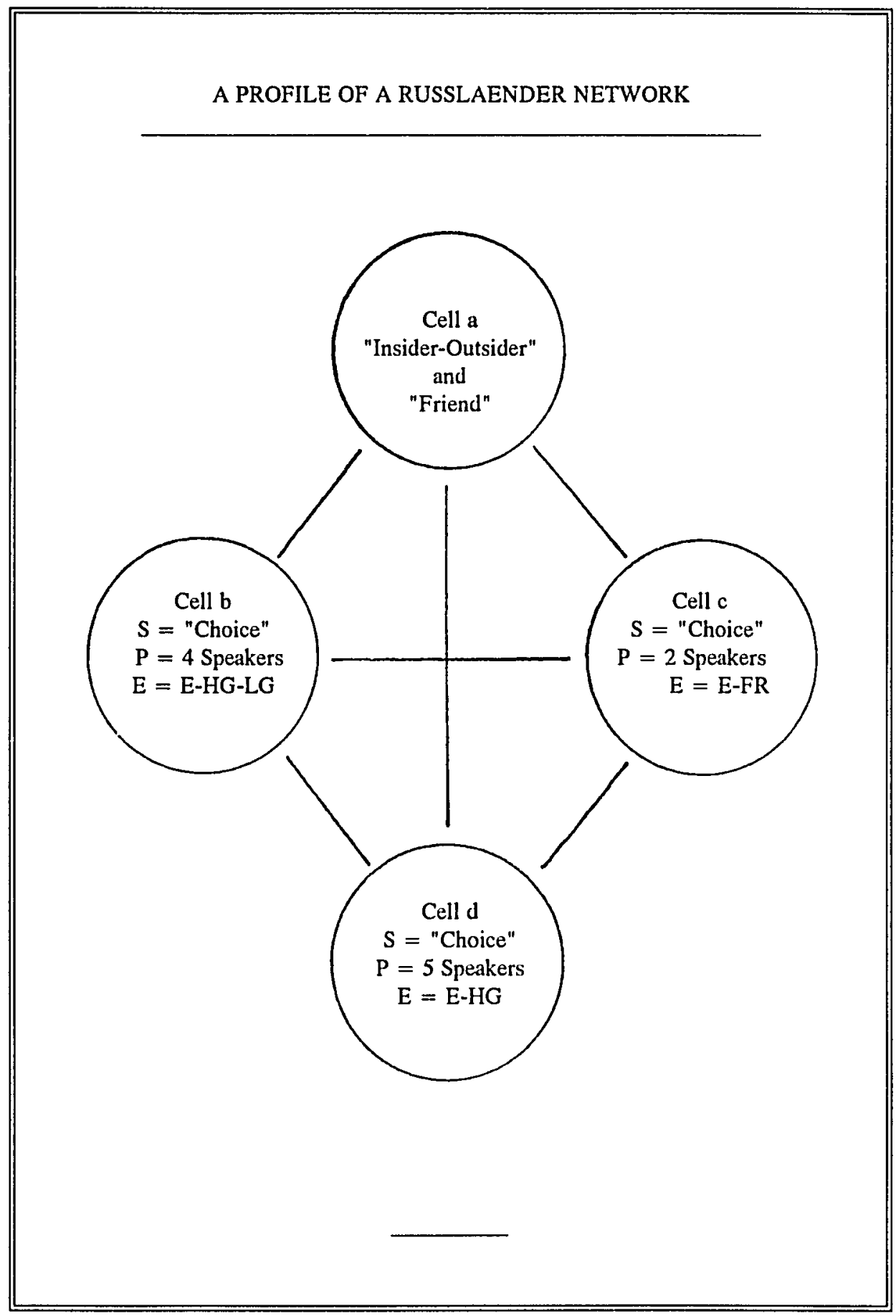

Figure 26. A profile of a Russlaender Network. A portion of the Russlaender Network with 100 percent density shows repertoires and language education "choice" or ends as reported by sixteen speakers. Source: Journal (1989). 
speech networks linked to German language, the Kanadier Network and the Russlaender Network, figures 25 and 26, respectively.

The Speech Community and Its Speech Fields -- Past and Present. Focusing on the scale of speech community and the variable of ethnicity, cell $a$ in figures 21 and 22 differentiates between the forty-eight speakers who are ethnic Mennonites and the nine speakers who are nonMennonites. Cells $b-k$ focus on the eighty-four percent who are ethnic Mennonite speakers, all of whom came in contact in English-only schooling before the 1970s and with bilingual schooling after the 1970s. Scanning across, cell $b$ in figures 21 and 22 differentiates between thirty ethnic Mennonites in the urban speech field and eighteen ethnic Mennonites in the rural speech field. Still scanning across, cells $c-d-e$ show mother tongue claims (figure 21) and home language use (figure 22) across the range of the community, the urban field, and the rural field. Cells $f-g-h$ show the codes of the meetinghouse, and cells $i-j-k$ show the codes of the schoolhouse. Scanning down, cells $a-c-f-i$ represent the pattern of code-choosing and codemixing in the home, the meetinghouse, and the schoolhouse of the speech community; cells $b-d-$ $g-j$ represent the pattern of the urban speech field, and cells $b-e-h-k$ represent the pattern of the rural speech field.

(a) Speakers in the Urban and Rural Speech Fields. Sixty-two percent of the ethnic Mennonites lived in the urban speech field and/or worked in urban settings tied to German language education. Speakers in private schools and employed as archivists, professors, teachers, preachers, or writers clustered themselves in relationships tied to Mennonite LG and HG studies located at the Centre for MB Studies in Canada, the Mennonite Heritage Center, and the Mennonite Studies Centre at the University of Winnipeg. Speakers in public schools and employed as administrators and teachers, or elected to local board positions clustered themselves in relationships tied to English-German studies at the Manitoba Department of Education and the River East School Division, or in voluntary capacities through the Manitoba Parents for German 
Education (MPGE), a public interest organization of parents, educators, and business leaders. Thirty-eight percent of the ethnic Mennonites lived in the rural speech field and/or worked in rural settings tied to German language education. Speakers in private schools associated themselves Mennonite LG and HG studies in voluntary capacities at the historical and literary societies. Speakers in public schools and employed as administrators and teachers, or elected to local board positions clustered themselves in relationships tied to English-German bilingual studies at the Manitoba Department of Education and the Hanover School Division, or in voluntary capacities through MPGE.

(b) Interaction and Change. Viewed apart, these profiles past and present depict a story of language dominance and language "death." The interacting and changing character of Mennonite diglossia and individual bilingualism, then, occurs as two patterns of code-choosing and code-switching in a Mennonite speech community and its speech fields. Traditional Mennonite diglossia is the pattern of the past. In its essence, traditional Mennonite diglossia was a stable societal arrangement in which two codes -- Plautdietsch, a $\mathrm{L}$ code, and Hochdeutsche, a $\mathrm{H}$ code -- existed side-by-side for centuries, well beyond the third generation of speakers. Modern Mennonite diglossia is the pattern in speech fields today. In its essence, modern Mennonite diglossia is an interactive societal arrangement in which speakers choose and mix three codes -- Plautdietsch, a L code, and Hochdeutsche and English, two $\mathrm{H}$ codes. The choices they make evidently are user-oriented rather than use-oriented. Viewed together, the profiles past and present show Mennonite diglossia to be an unstable situation with patterns of code-choosing, code-mixing, and code-shifting. In sum, the diglossic situation can be characterized as "transitory" bilingualism without diglossia, a pattern that inevitably leads to unstable bilingualism and eventual monolingualism (Ferguson, 1959; Fishman 1967). Clearly, English language dominance did something to the life of language in the Mennonite speech community. 
Kanadier and Russlaender Repertoires -- Past and Present. Focusing again on the scale of speech community and the variable of ethnicity, cell $a$ in figures 23 and 24 , differentiates between the forty-eight speakers who are ethnic Mennonites and the nine speakers who are nonMennonites. Scanning across, cell $b$ in figures 23 and 24 differentiates between twenty-two Russlaender and twenty-six Kanadier, two sub-groups of ethnic Mennonites whose speech repertoires differ. Still scanning across, cells $d$-e show mother tongue claims (figure 23) and home language use (figure 24) among Russlaender and Kanadier. Cells $g-h$ show the codes of the meetinghouse, and cells $j-k$ show the codes of the schoolhouse. Scanning down, cells $b-d-g-j$ represent repertoire of the Russlaender in the home, the meetinghouse, and the schoolhouse. Cells $b-e-h-k$ represent the repertoire of the Kanadier in the home, the meetinghouse, and the schoolhouse. Finally, in contrast to the repertoires of Russlaender and Kanadier, cells $a-c-f-i$ represent the repertoire of a small group non-Mennonite speakers who identify with a German national heritage and who promote English-High German bilingual education in Manitoba schools.

(a) Speakers With Kanadier and Russlaender Identities. Kanadier were defined earlier as ethnic Mennonites who identified with the first wave of Russian-Mennonite immigrants and who generally settled in the rural speech field, in the towns and villages on the Mennonite reserves between the 1870 s and 1880 s. Russlaender were defined as ethnic Mennonites who identified with the second and third waves of Russian-Mennonite immigrants and who generally settled in the urban field between 1920-1930, and between 1940 and 1960 . Because of their respective histories, Kanadier and Russlaender attitudes about the use of E-HG-LG differ. In the case of the Russlaender, speakers' use of HG and LG was influenced by competition between German and Russian as standard national languages in Eastern Europe. Among those Russlaender who lived in the Molotschna Colony during the twentieth century, speakers developed a pattern of mixing High German and Low German and switching from High German 
to Russian. In the case of Kanadier, speakers' use of HG and LG was influenced by English as a standard national language in Canada. Among the Kanadier who lived in the towns of Steinbach, Winkler, and Altona for three generations, speakers developed a pattern of mixing Low German and English and shifting from High German to English. Movement in recent decades, though, from rural villages, to rural towns, to urban villages has distributed these Kanadier and Russlaender and their repertoires beyond rural and urban distinctions.

Nevertheless, these geographically remote yet related trends toward standardization of national languages in Russia and Canada eventuated in distinct patterns of code-choosing and codemixing among Russlaender and Kanadier respectively. As Fishman (1967) said about interaction between diglossia and bilingualism, instead of "two carefully separated languages each under the eye of caretaker groups of teacher, preachers, and writers" (p. 36) a new pattern of language mixing and switching became the mother tongue of the new generation.

(b) Interaction and Change. Viewed apart, profiles of Kanadier and Russlaender, past and present, depict another story of language dominance and language "death" with a variation on the theme of "dominance." Within the story of English dominance is another story of High German dominance. The interactive field of Mennonite diglossia and individual bilingualism, shows that the pattern of traditional Mennonite diglossia, HG-LG, links Kanadier and Russlaender in certain ethnically encumbered language situations, particularly those language situations evoking the use of LG. The pattern of modern Mennonite diglossia, E-HG-LG, though, tends to separate Kanadier and Russlaender in ethnically unencumbered situations, particularly those language situations and education situations prompting the use of HG. So preference for HG in the Russlaender repertoire separates some Russlaender from some Kanadier in some situations, and links some Russlaender to "German Germans," as they say, in other situations. Viewed together, the profiles of Kanadier and Russlaender repertoires, past and present, show another pattern of code-choosing, code-mixing, and code-shifting. In sum, 
Mennonite diglossia remains a situation that can be characterized as "transitory" bilingualism without diglossia, a pattern that inevitably leads to unstable bilingualism and eventual monolingualism. Clearly, High German preference among Russlaender also did something to the life of language in the Mennonite community and school.

Profiles of a Kanadier Network and a Russlaender Network. Focusing the description now on the scale of speech network, two profiles illustrated in figures 25 and 26 , differentiate between the Kanadier Network and the Russlaender Network. To review the significant network concepts introduced in Chapter II and elaborated on in Chapter III, Hymes (1986) defined the speech network, the specific linkages of speakers whose individual repertoires and patterns of speaking allow them to move communicatively across the speech field. This concept applies to both the Kanadier Network of twenty-six speakers and the Russlaender Network of twenty-two speakers. Next, Fishman (1980) defined a network as either a "closed network" in which traditional, "ethnically encumbered" situations evoking the use of "high" or "low" were strictly compartmentalized or as an "open network" in which modern "ethnically unencumbered" situation prompting the use of "high" and "low" were blurred or fluid. This binary distinction also applies to both the Kanadier and Russlaender networks. Finally, Milroy (1986) conceived of network as a mechanism of enforcement in small groups linked together by the content and purpose. As explained in Chapter III, she used the terms "density" and "multiplexity" of network structure to describe issues of maintenance. As noted earlier, she identified five conditions as indicators of density and multiplexity: (1) neighborhood ties to the urban or rural speech fields of the community, (2) kinship and family ties to the Anabaptist-Mennonite tradition of the speech community, (3) professional, election, or voluntary ties to language education policy, practice, or choice in Manitoba public schools or Mennonite private schools, (4) gender ties to condition (3) above, and (5) voluntary social or leisure ties to conditions (3) and (4) above. Given these significant concepts of network and their application to Kanadier 
and Russlaender speech networks, it is now possible to describe (a) a portion of the Kanadier Network with a network density of 100 percent, (b) a portion of the Russlaender Network with a network density of 100 percent, and (c) the interaction of components of SPEAKING. Data used to described these networks is derived from the chart of language and social variables titled "Network Index Sort" located in Appendix F.

(a) The Kanadier Network. The Kanadier Network, illustrated in figure 25, is defined as sixteen speakers (1) whose repertoire of E-HG-LG allows them to move communicatively across the Mennonite speech fields, (2) whose mother tongue is a mixed pattern of E-LG and whose pattern is to use LG in "ethnically encumbered" language and educational situations and to use $\mathrm{E}$ in "ethnically unencumbered" language and educational sittations, and (3) whose network index score of five indicates that the network is multiplex or many stranded. According to Milroy, "speakers . . . in a multiplex [network] relation . . . are more susceptible to the obligation to adopt group norms" (Milroy, 1986, p. 60). Given this introduction to the Kanadier Network, cell $a$ represents my role as an insider-outsider and my relationship as a friend-of-a-friend. Cell $b$ represents eight participants (P) who speak E-HG-LG and who use EHG-LG to promote LG in the Mennonite Studies program at the university. Cell $c$ represents four participants whose use of E-HG-LG and promote E-FR or "official bilingualism" in French immersion programs in local schools. Cell $d$ represents four participants whose use of E-LG and promote $E$ and basic language enrichment programs in local schools. The trend in Canada toward standardization of E before 1970 and toward E-FR after 1970 is evident in the new generation of Kanadier, for these speakers make language education choices based on their mixed E-LG mother tongue and the:i acceptance of E-FR as a national standard.

(b) The Russlaender Network. The Russlaender Network, illustrated in figure 26, is defined as eleven speakers (1) whose repertoire of E-HG-LG allows them to move communicatively across the Mennonite speech fields, (2) whose mother tongue is a mixed 
pattern of E-HG-LG and whose pattern of code-choosing and cocle-mixing is related contextually to language situations characterized as "ethnically encumbered" and "ethnically unencumbered," and (3) whose network index score of five indicates that the speakers' network tie is multiplex or many stranded. Here too, speakers in a multiplex network more susceptible to group norms. Again, given the terms above, cell $a$ represents my role as an insider-outsider and my relationship as a friend-of-a-friend; cell $b$ represents four participants who speak E-HG-LG and use E-HG-LG and promote LG in the Mennonite Low German studies at the university. Cell $c$ represents two participants who speak E-HG-LG and promote E-FR or official bilingualism in local schools. Cell $d$ represents five participants who speak E-HG-LG and promote E-HG or "non-official" bilingualism in local schools. The trend in Canada toward standardization of EFR or official bilingualism after 1970 and more recently toward E-HG or "non-official" bilingualism after 1980 is evident in the new generation of Russlaender, for these speakers make language education choices based on their mixed E-HG mother tongue and their acceptance of EFR as a national standard.

(c) Interaction and SPEAKING Plautdietsch. Event One: Telling Stories of Plautdietsch, is a series of speech acts that took place at four Mennonite heritage centers. To review, SPEAKING, used to outline Event One and to explain Event One, is a mneumonic code described in detail in Chapter II, used as a data collection method in Chapter III, and applied to data analysis here. The code represents the following components of speech: $S=$ setting/scene where language "choice" is part of the local school policy and practice, $\mathrm{P}=$ participants, $\mathrm{E}=$ ends or goals, $A=$ act sequence, $K=$ keys or tone, $I=$ instruntentalities or linguistic codes, $N$ $=$ norms of interaction, and $G=$ genre (Hymes, 1986).

$\underline{G E N R E=\text { Event One: Telling Stories of Plaurdietsch }}$

Components:

$S=$ Mennonite LG studies located at Mennonite private institutions Centre for MB Studies in Canada Mennonite Heritage Centre 


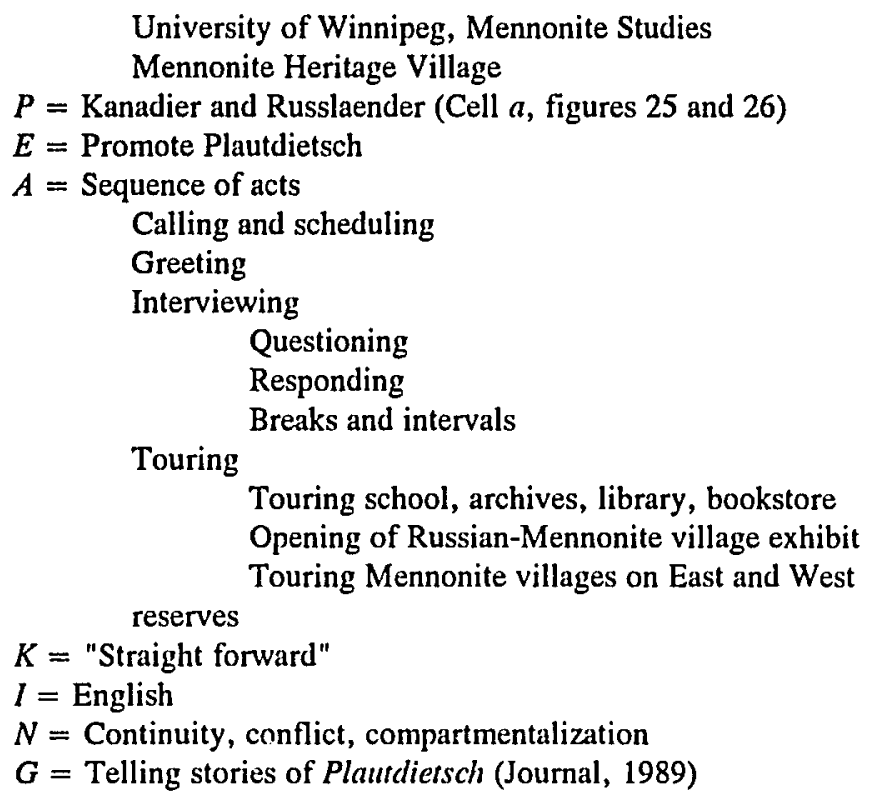

Settings and scenes included the Centre for MB Studies in Canada; the Mennonite Heritage Centre; the University of Winnipeg, Mennonite Studies Centre; and the Mennonite Heritage Village Museum. The participants in this speech event include the eight Kanadier and four Russlaender represented by ceil $a$ in figures 25 and 26 . According to speakers, the aims or ends of these heritage institutions are (1) to "support teaching and research in areas of ethnic history, cuiture, and language in higher education" (Journal, 1989, p. 2), (2) to "preserve heritage language and culture in the life of the community" (Journal, 1989, p. 4), and (3) "to give a further impetus to Low German writing" (Journal, 1989, p. 46). My exchanges with these participants occurred as a sequence of acts that included tours of each institution, introductions to participants and their colleagues, and interviews followed invitations to talk with local writers and speakers in other zones of the network. Generally the key or tone of this event and sequence of acts was straight forward and positive. Males tended to be aloof and serious in dyadic relationships with females and friendly and humorous in triadic relationships involving other males. Females tended to be positive, interested, and friendly. Using the instrumentality of spoken E, participants referred me to works in LG. Shelves of recent LG 
writings characterized as "small masterpieces" of "pathos and humor" reflecting "Mennonite values and language" (Loewen \& Reimer, 1985) indicated that these participants valued certain speakers and writers of the past. Specifically, they recognized educator Jacob Janzen (18781950), poet Fritz Senn (1894-1983), and storyteller Arnold Dyck (1889-1979) for breathing life into Plautdietsch, the traditional mother tongue. And they valued certain speakers and writers in the community today (Doerksen, Epp, \& Loewen, 1986, 1987; Doerksen \& Loewen, 1985; Klassen, 1989; V. Friesen, 1988; H. Loewen, 1980; K. Loewen \& Reimer, 1982; J. Loewen, 1989; Reimer, Reimer, \& Thiessen, 1983; Rempel, 1984).

Issues of continuity, conflict, and compartmentalization came up as speakers differentiated between Molotschna and Chortitza varieties of LG and the norms governing their use. In the case of the varieties themselves, since the early 1970 s, a movement has been underway in the community and at the university to codify the Mennonite oral tradition in LG. Recent endorsements of the Molotschna variety and its codification have revived an intra-ethnic rivalry between Russlaender who prefer to use the Molutschna variety to tell stories and Kanadier who prefer to use the Chortitza variety to tell stories (Journal, 1989, pp. 2, 39, 46). In sum, Event One, Telling Stories of Plautdietsch together with the profiles of codechoosing and code-mixing, illustrated in figures 21 through 24 , shows that LG, while still the code of hearth and home, is a "dying language." The movement to codify the vernacular further suggests that Plautdietsch is not only a part, an index of Mennonite ethnicity, and a symbol of a Mennonite ethnicity. For traditional Plautdietsch speakers use the language to recreate the fivehundred-year-old legacy. Plautdietsch symbolizes a traditional way of life on the East Reserve and West Reserve between 1890 and 1990; a traditional way of life in Chortitza and Molotschna regions of Russia during the nineteenth century; a traditional way of life in the Danzig, 
Marienburg, and Elbing regions of Prussia in the sixteenth and seventeenth centuries. Indeed Plautdietsch dates back to the mid-1500s and symbolizes the Russian-Prussian-Frisian tradition of Anabaptism.

(d) Interaction and SPEAKING Hochdeutsche. Event Two: Telling Stories of Hochdeutsche, is a series of speech acts that took place in Manitoba public schools. Again, the mneumonic code SPEAKING is used to outline Event Two and to explain Event Two.

\section{GENRE = Event Two: Telling Stories of Hochdeutsche}

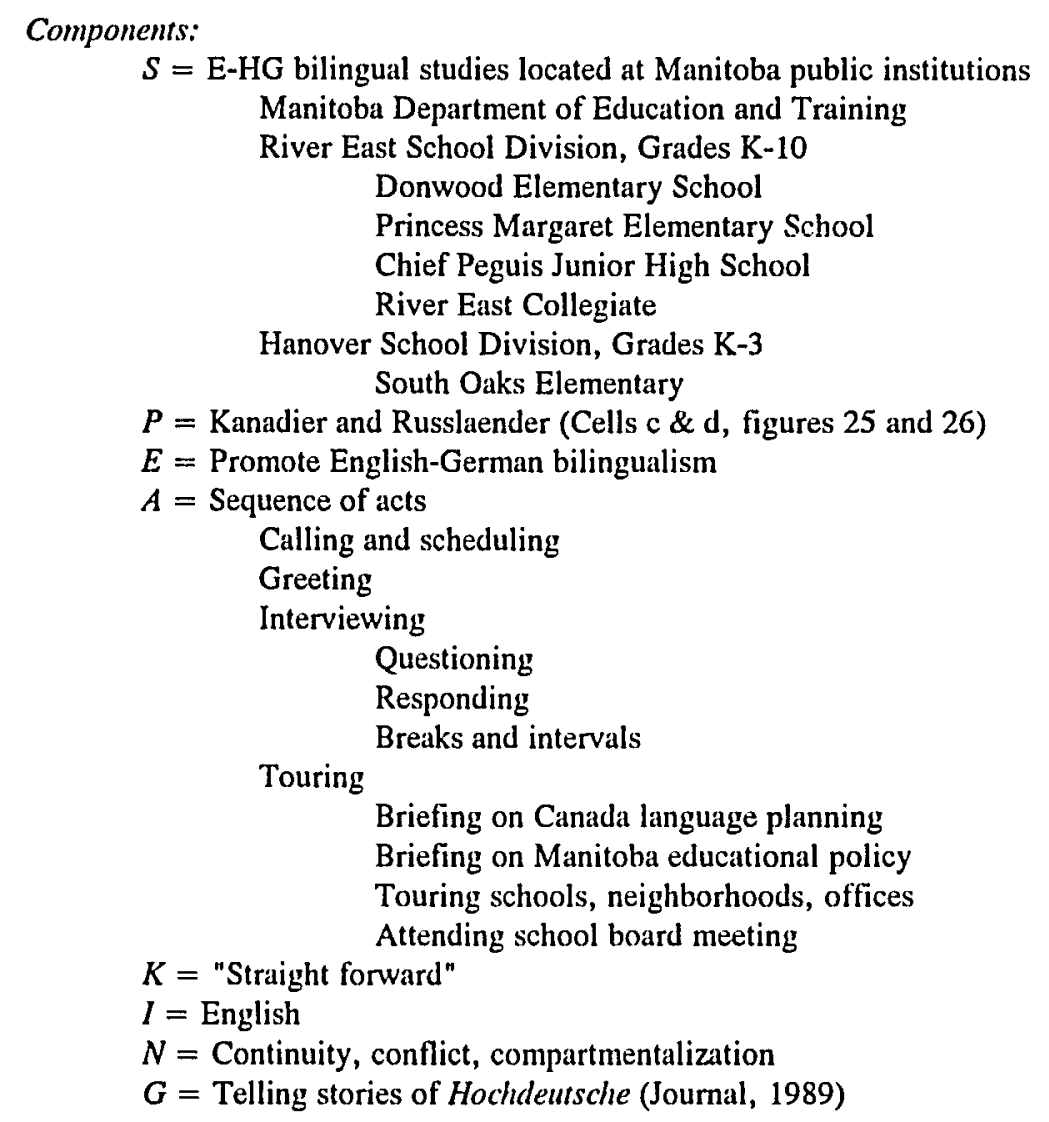

Settings and scenes included the Manitoba Department of Education; the River East

School Division and two schools, Donwood Elementary School and Princess Margaret

Elementary School; and Hanover School Division. The participants in this speech event include eight Kanadier and seven Russlaender represented by cells $c$ and $d$ in figures 25 and 26 . 
According to speakers, the aims or ends of these public institutions are (1) to promote language education "choice" by providing an "effective learning environment ... . effective teaching practices ... [through] curriculum and programs [in] "promote bilingual programs in Francais and immersion ... multiculturalism . . . Native education . . . and [heritage] languages" (Journal, 1989, pp. 3, 4, 5, 9, 21); (2) to "promote German as a language of study and a language of instruction ... through bilingual programs" in which half the school day is devoted to subjects in E -- English language arts, mathematics, and science -- and half the school day is devoted to subjects in G -- German language arts, social studies, music, art, and physical education (Journal, 1989, p. 5; Manitoba Department of Education, 1983a; MPGE, 1988); and (3) to "benefit . . . cognitive development . . . improve . . . academic performance in other subject areas ... [and] promote a favorable outlook on ... one's ethnocultural background and cultural differences of others" (Joumal, 1989, pp. 3, 4, 5, 6, 9, 13, 14, 21). My exchanges with these participants occurred as a sequence of acts that included briefings on Canadian language planning and policy and Manitoba educational policy (Joumal, 1989, pp. 4, 5, 9), tours of local schools (Journal, 1989, pp. 3, 36, 38, 42, 43), and meetings with local school board members (Journal, 1989, pp. 30, 34, 41, 44, 53, 54) and parent advocates (Journal, 1989, pp. 13, 14, 28, 29, 32, 37). Without exception, the key or tone of this event and sequence of acts was collegial and in the spirit of exchange between educators from two countries. Using the instrumentality of spoken E, participants referred me to the history of the Manitoba school question, to laws and statutes at federal and provincial levels, as well as pending legislation, and to Department of Education initiatives in local school divisions. They gave me access to reports on funding, policy, curriculum and training, and enrollment figures (Manitoba Department of Education, 1983a, 1983b, 1988, 1989a, 1989b, 1989c) and reviews of Canadian literature on heritage language research (Journal, 1989, p. 5). 
Issues of continuity, conflict, and compartmentalization came up as speakers differentiated between varieties of HG used by Mennonites and non-Mennonites and the norms governing their use. For example, Russlaender tended to express the value of HG and associated it with the traditional Mennonite press including such publications as Die Steinbach Post (1913), Der Bote (1924), and Die Mennonitishe Rundschau (1880) (Journal, 1989, pp. 1, $2,8,17,18,44,45,46,54)$. Their comments suggested to me that they valued this language both as a spoken and a written language suggesting that the traditional role of the literary tradition had changed. Russlaender also tended to see education in German national culture as a source of conflict stemming back to centuries-old resistance to nationalism. Kanadier tended to associate HG with the pain and prejudice experienced by individual Mennonites and by the Mennonite community as a whole when German was "declared" the language of "the enemy" in the 1920 s and the 1940 s (Journal, 1989, pp. 8, 9, 10, 30, 31, 38, 42, 43). Talk of HG reminded them of a community divided over compulsory education, English-only schools, and corporal punishment as a mechanism of enforcement. These Kanadier generally expressed a preference for $\mathrm{E}$ or E-FR in matters of language education choice. Some, particularly females, spoke of their use of English with an air of new-found identity and authority (Journal, 1989, pp. $20,24,27,57)$. Between these extreme views of $H G$ and of $E$, there appears to be a preference on the part of Kanadier for E or E-FR and on the part of Russlaender for E or E-HG in matters of "choice." Consistently across the community, the field, and the network speakers pointed with pride to pilot programs in schools on the North End and on the East Reserve as evidence of a forward-thinking language policy promoting multiculturalism and bilingualism in Canada and language education choice in Manitoba (Joumal, 1989, pp. 1, 2, 4, 6, 8, 10, 44). Only Kanadier expressed reservations about E-HG bilingual programs. They stated concem about (a) funding after pilot programs were fully implemented, (b) transportation in the consolidated rural division, and (c) the retraining of current teaching staffs. One Russlaender, an appointee to the 
Royal Canadian Commission of Biculturalism and Bilingualism, spoke of his role in representing a "non-Founding" minority before the Commission and Parliament. He referred to the Commission as the "B \& B" as he raised interesting questions. He asked: Is "Multiculturalism Within a Bilingual Framework" another attempt to "nationalize" immigrants and Native peoples? Will the "Canadian Cultural Mosaic" further "ghettoize" minorities? Others raised similar questions (Journal, 1989). As if to answer the question, he and others pointed with pride to the Mennonite Studies Center at the university, the Mennonite Heritage Centre, the Mennonite Heritage Village Museum, and the centennial celebration of Mennonites in Manitoba as evidence of a significant trend toward cultural pluralism in Canada (Journal, 1989, p. 44).

In sum, among the Kanadier, policy-makers, educators, and parents tend to promote $\mathrm{E}$ and E-FR in matters of school langauge choice while the Russlaender tend to promote E-HG or E-FR in matters of school language choice. In ethnically encumbered language situations, though, both groups identify with LG.

\section{Both a Diachronic View and a Synchronic View of Mennonite Diglossia}

Preliminary answers to the question who uses which language with whom, when, where, and why have been based on two views of SPEAKING, a diachronic view derived from Ferguson's (1959) diglossia and a synchronic view derived from Fishman's (1967, 1980) societal diglossia and individual bilingualism and from Hymes' (1974,1980, 1986) ethnography of speaking. First, Ferguson's model provided a framework with which to examine the legacy of Mennonite dualism and to illustrate three conditions that contributed to the diglossic situation in the Mennonite speech community. The history showed that (1) within the Mennonite speech community, there exists a literary tradition in HG, an oral tradition in the linguistically related LG, and a system of beliefs symbolized in both traditions, that (2) literacy has been limited to German-only, and that (3) the two former conditions have persisted at least four centuries. The 
situation fulfilled the conditions which characterize Ferguson's diglossia and explained why traditional Mennonites used HG in the meetinghouse and schoolhouse and LG in the home and village. Further, the discussion of the literary tradition and the oral tradition, specifically the linguistically relatedness factor and the function factor, illustrated how issues of acquisition, standardization, prestige, literary heritage, phonology, grammar, and lexicon all contributed to the stability of the situation. Continuing with Ferguson's model, the legacy of Mennonite diglossia also illustrated that trends toward (a) increased literacy in English as a standard language in Canada, (b) interaction between groups in school and community, and (c) widespread desire for "national" English schools and English as a symbol of British-Canadian sovereignty contributed in the last one-hundred years to an unstable diglossic situation leading to transitory bilingualism and eventual monolingualism. This model depicts conditions that existed when the Mennonites emigrated from Russia to Canada during the 1870 s and 1880 s. It accounts for trends toward English-only dominance in school and community that prevailed until recently. This model explains (1) the shift from the traditional Mennonite repertoire of HG-LG to the modern Mennonite repertoire of E-HG-LG, (2) the shift from LG as a mother tongue to E-LG as a mixed mother tongue, and (3) the shift from HG, a god's tongue, to E-HG, a mixed god's tongue.

Next, Fishman's model provided a framework with which to describe the dynamic nature of an interactive and changing ethnolinguistic situation. Interaction between traditional Mennonite diglossia and English-German bilingualism when examined closely revealed four relationships between societal diglossia and individual bilingualism. Analysis of the data revealed four patterns: (1) diglossia with bilingualism, (2) diglossia without bilingualism, (3) bilingualism without diglossia, and (4) neither bilingualism nor diglossia, all present in the community today. Profiles of code-choosing and code-mixing displayed at the level of the speech community, the speech field, and the speech network tell a story of language dominance 
and language "death." Specifically, the profiles of the Mennonite speech community and its urban and rural speech fields show that $E$ replaced HG in the schoolhouse after the 1920 s, that $E$ replaced HG in the meetinghouse after the 1950s. Gradually, between the 1920s and the 1970s, E mixed with LG in the home. The profiles of the Kanadier and Russlaender repertoires show that within Mennonite speech community itself, the language history of Kanadier differs from the language history of Russlaender. The Kanadier were first-wave of immigrants. Today, after three generations in Canada, speakers choose $\mathrm{E}$ in the home, the schoolhouse, and the meetinghouse with greater frequency. The Russlaender, on the other hand, were the secondand third-wave immigrants. Today, after one or two generations in Canada, Russlaender maintain use of HG in the meetinghouse with greater frequency than the Kanadier. Among both sub-groups, the use of LG is declining. While the profiles show some evidence of (1) both diglossia and bilingualism, (2) diglossia without bilingualism, (3) bilingualism without diglossia, and (4) neither diglossia nor bilingualism among Kanadier and Russlaender, the pattern of bilingualism and diglossia is more prevalent among Russlaender and the pattern of bilingualism without diglossia with a tendency toward monolingualism is more prevalent among Kanadier.

Finally, Hymes' model provides a framework with which to summarize the situation in terms of components of speech acts. Relations between components of speaking offer a basis for examining who chooses (or mixes) what language with whom, when, where, and why. These components explain preliminarily, on one hand, Russlaender's preference for E-HG bilingual education in matters of language education choice, and on the other hand, Kanadier's preference for $E$ with German enrichment programs or for E-FR bilingual education in matters of language education choice. Language education policy has changed in Manitoba and Canada. Given these patterns of code-choosing and code-mixing in a Mennonite speech community, language attitudes evidently are changing too. 


\title{
CHAPTER V
}

\section{COMING FULL CIRCLE: AN ETHNIC REVIVAL IN SCHOOLS AND SCHOOLING}

\begin{abstract}
Viewing the ethnic revival in the United States in the 1960s and 1970s and its co-occurance among indigenous minorities in Western and Northern Europe and "non-Founding" minorities in Canada as a widespread response to a uniformizing ethos, a sociolinguist says ...
\end{abstract}

Sidestream ethnicity is a phoenix in modern life; it constantly arises anew from its apparent ashes. But the ashes are more apparent than real. . . Ethnicity is "a far more durable and powerful phenomenon that is usually depicted, . . . it draws on far deeper historical roots" . . . and goes through many more transformations "than many would allow" . . . Ethnicity is constantly restructuring and recreating itself and its future, all around us, well into and beyond the third generation . . . Like most other aspects of culture, it waxes and wanes in response to more powerful and encompassing developments. Like most other aspects of culture, it does not follow a straight line (pp. 684-686).

Joshua Fishman (1985)

\section{HISTORY NEED NOT REPEAT ITSELF}

Histories give little attention to language dominance in school and community -- to the

fact that one-hundred years of "One People, One Language, One School" attitudes, policies, and goals in schools and communities have brought with them the demise of Native-American languages, the disappearance of immigrant languages, the stereotype of regional and ethnic languages, and the insistence on English as a mark of linguistic and intellectual virtue. While An Ethmography in Canada gives attention to one such history in Anglo-Canadian schools and 
schooling, it could give attention to similar histories in Anglo-American schools and schooling.

While this story is told in Mennonite perspective and framed in Manitoba schools between 1890 and 1990, the story could be told from the perspectives of Native-Americans, AfricanAmericans, Asian-Americans, or Latin-Americans. It could be framed in schools in the American states. While Telling Stories (Out of School) began with a story of Anglo-Canadian insistence on and German Mennonite resistance to English-only language education policies in public and private schools serving a Mennonite speech community in southern Manitoba, it could begin with a story of Anglo-American insistence on and Hispanic, Vietnamese, Chinese, Aboriginal resistance to English-only and transitional language policies in schools and schooling in the American states.

As this discussion of Telling Stories (Out of School) of Mother Tongue, God's Tongue, and the Queen's Tongue comes full circle, one interpretation is clear: histories need not repeat themselves. A change in language education policy can lead to a change in language attitude. So, while the story of a Mennonite speech community in southern Manitoba ends with a revival of ethnic language and culture via "Multiculturalism Within a Bilingual Framework" and "language education choice, " stories of minority languages in American states end with the decline of ethnic language and the shift from sidestream mother tongue to mainstream mother tongue via U.S. bilingual policies aimed at transitional bilingualism and eventual monolingualism. Indeed, a proposed English Language Amendment has been on the agenda of the American Congress since 1981, and sixteen states have passed official English statues as of 1990 (Judd, 1989, p. 27). These broad pictures remain all too clear.

\section{ISSUES, IMPERATIVES, AND QUESTIONS}

While this inquiry focused on what fifty-seven speakers said about their use of language in the past, in the community and school of their childhood, and their use of language today, the 
community and school of their livelihood, it raised issues of continuity and change, maintenance and shift; it suggested some imperatives for change; and it raised some questions.

U.S. Policy-Makers, Educators, and Linguists Should Take a Look at Historical Problems of One People, One Language, One School Policies

In the case of the Mennonite speech community in Canada, the historical problem related to a series of language education acts passed by the Manitoba Legislature, adjudicated by the Manitoba Attorney General, the Canadian Supreme Court, and the British Privy Council, and enforced by the Manitoba Department of Education -- all between 1890 and 1920 . These English-only policies, deemed an expedient response to the question of how to unify EnglishCanadians, French-Canadians, Aboriginals, and immigrants, abrogated the language education rights of all linguistic minorities. English prevailed in Manitoba schools until the 1960s. After the mid-1960s, though, the Canadian Parliament in concert with the Manitoba Legislature, the Manitoba Department of Educaiion, and local public school districts re-affirmed Canada's English-French legacy as well as its multilingual, multicultural heritage with yet another series of language and language education acts -- the Canadian Official Languages Act of 1969, the Canadian Constitution Act of 1982, and the Canadian Multicultural Act of 1988. Today, the Canadian "Cultural Mosaic," or "Multiculturalism Within a Bilingual Framework," dispels the "Melting Pot" myth borrowed from the United States at the turn of the century. And, the 1990 right to "language education choice" in Manitoba's system of public schools denies the 1890 rule of "One People, One Language, One School."

"One People, One Language, One School" attitudes, policies, and goals in Manitoba schools evidently did do something to the life of language in a community in 1920. Suddenly, when the courts denied Mennonites German language education rights, English displaced High German in the schoolhouse, and English taunted Low German on the playground. English rules prevailed in the schoolhouse until the courts restored language education rights to linguistic 
minorities in 1970. I By then, four decades of English dominance had blurred linguistic distinctions between the secular from the sacred, the traditional from the modern, the mainstream from the sidestream. Compartmentalization gave way to fluidity not only in the schoolhouse, but in the home and the meetinghouse as well. In the late 1950s and early 1960s, after a decade of internal debate, Mennonite congregations officially permitted the use of English in religious services and religious publications (Journal, 1989, p. 1). At that point, the tradilional pattern of choosing Low German at home and High German in the meetinghouse and the schoolhouse, "officially" changed to a modern pattern of choosing and mixing Low German and English at home, High German and English in the meetinghouse, and English in the schoolhouse. Evidently, the norms and rules for the use of Low German, High German, and English have interacted and changed from a traditional "use-oriented" diglossia to a modern "user-oriented" diglossia (Britto, 1986, 35-40). Speakers developed a speaking repertoire to use in "closed networks" involving "ethnically-encumbered" life and traditional pursuits and a speaking repertoire to use in "open networks" involving ethnically unencumbered life and modern pursuits (Fishnan, 1967, 1980). Dodson (1989) summed it all up: "Bilingualism without diglossia is a transitory situation leading inevitably to unstable bilingualism and evenllually to monolingualismı" (p. 387).

U.S. Policy-Makers, Educators, and Linguists Should Take a Look at Canada's Idea of Cultural Pluralism

"Multicultualism Within a Bilingual Framework" in Canada and "language education choice" in Manitoba evidently are doing something to the life of language in a community now. Given history and the broad picture of language in Anglo-American schooling, "Mullticulturalism Within a Bilingual Framework" appears to be a promising alternative to "One People, One Language, One School" attitudes, policies, and goals. Top administrators with the Manitoba Department of Education and Training described how the agency, in cooperation with 
the Canadian Secretary of State and the Manitoba Department of Culture, Heritage, and Recreation, supports "Multiculturalism Within a Bilingual Framework" or language education "choice" in Manitoba public schools. Two local public school divisions serving Germanspeaking Mennonite populations have instituted English-German bilingual education programs in local public schools since programs were piloted in the early 1980s (Manitoba, 1983a, 1983b, 1988, 1989a, 1989b, 1989c). Student enrollments in English-German bilingual programs have increased through the 1989-1990 academic year (Dyck, 1986; Journal, 1989; Plett, 1986; River East, 1989a, 1989b). Additionally, the Manitoba Department of Culture, Heritage, and Recreation, in cooperation with the Canadian Secretary of State, supports teaching and research in areas of ethnic history, culture, and language in higher education. Two decades of multicultural-bilingual policies and practices have brought new life to the role of heritage language and culture in the life of the comm :ity (Journal, 1989). Canada has altered the course $\mathrm{c}$ : its language and cultural history with a futuristic notion of Canadian unity through ethno-cultural plurality. Policies have changed. Attitudes have changed.

A View of the Micro-Level of the Community and the Local School. At the microlevel of the Mennonite community itself, educational policies and practices have changed the way language development is viewed. Change, though, appears to pace itself differentially at the scales of the speech community and its networks of policy-makers, educators, and parents. In the aftermath of multicultural and bilingual mandates and language education choices, sources inside and outside the Mennonite speech community said some local policy-makers, educators, and parents opted for French-English programs; others preferred basic language enrichment programs; still others chose English-German bilingual programs (Journal, 1989). After "language choice" legislation in the early 1980s, two local school boards piloted and implemented local English-German bilingual programs. In the urban school division in Winnipeg, parents showed "considerable support for ... [bilingual] program of studies," and 
the board members supported the proposal "for expansion into senior high" in 1990 (River East, 1989b). Minutes of an advisory committee meeting stated that "River East School Division appears to be at the leading edge of German bilingual education in Canada" (River East, 1989c). In the consolidated rural division outside Winnipeg, parents made a "last-ditch pitch" to expand a bilingual elementary school program, but board members denied a parent petition to develop the program beyond a K-3 pilot program (Plett, 1986). A news account of Hanover School Division board proceedings stated that the advisory committee found "the bilingual program . . . basic German . . . basic French . . . 'a confusing and costly' variety of options" (Plett, 1986). So the debate of English-German bilingual program, characterized as the "English-GermanFrench trilingual program" continues (Dyck, 1986).

Reflecting on Canadian social policy in the first half of the twentieth century, on the gradual shift from German to English in the Mennonite community, and on the debate in local schools, a retired educator, fluent in English, Low German, and High German, said:

[Multiculturalism Within a Bilingual Framework] comes too late . . The post World War I years were not favorable to teaching any language, particularly German. To facilitate learning English ... to discourage speaking German . . . . . . school districts restricted High German instruction to the last half-hour of the day . . . [and] used detentions and corporal punishment to discourage [children] from speaking Low German on the playground ... Strong antiGerman sentiment after the wars . . . consolidation of school divisions ... [and] bussing of children to large high schools devastated the infrastructure . . the infrastructure is gone.

We should have done what the French did ... Use French!

The Anglo-Saxons are generous when it is too late to rebuild the infrastructure (Journal, 1989, p. 8).

Reflecting on the second half of the century, on Manitoba's bilingual enrichment educational policies and on the apparent revival of interest in language and ethnicity, an ethnographer and musicologist said: Canadian pluralistic social policies "have helped to create an atmosphere in which it is not only acceptable, but even desirable to express one's ethnicity" (Klassen, 1989, p. 
6). Yet another educator, commenting on the centennial celebration of Mennonites in Manitoba, said:

The Centennial Celebration . . . one-hundred years of residence in Manitoba . .. was like the beginning of a renaissance in Low German . . . drama, singing, writing, academic work . . . all in Low German. The celebration presented . . . angles of our cultural distinctiveness ... not so much of our theological distinctiveness. New pieces were written and performed for the centennial program. Before 1974, almost nothing was written in Low German. Since 1974, at least twenty-five titles have been published in Low German. Low German has become a literary vehicle . . . a way to express a lost humor . . . a way to have fun ... a certain richness to pass on to my children ... a forgotten treasure unearthed (Journal, 1989, p. 6).

Finally, a writer in Low German and professor of English said:

Plaurdietsch as the [vernacular] . . . language of Canadian Mennonites is rapidly disappearing . . . yet, in recent years there have been encouraging signs, in Manitoba at least, of a growing interest in Plautdietsch as a literary vehicle. While hardly a "renaissance," this renewed interest seems to be more than a passing fad or a last nostalgic twitching of our ethnic nerve ends (Reimer, 1983, p. 1).

So, here at the micro-level of the local speech community and its schools, policies have changed, and attitudes vary.

A View of the Macro-Level of Communities and Schools. Moving to a broader view, beyond the local speech community, Manitoba policy-makers and educators who oversee language education policy and practice in Manitoba public schools say local communities have taken advantage of federal and provincial legislation enabling them to exercise "language education choicen in local schools (Ducharme, 1988; Manitoba Education, 1989a). Francais and French immersion programs piloted in the 1970s, and English-German, English-Hebrew, and English-Ukrainian bilingual programs piloted in the 1980s, have gained community acceptance (Manitoba Education, 1983a, 1983b, 1988, 1989a, 1989b, 1989c, 1990). Manitoba's assessments of those bilingual programs indicate that students master content in both languages, achieve proficiency in English equal to students in English-only programs (Manitoba Education, 1988, p. 12), and "learn tolerance and gain self-confidence in their own abilities" (Manitoba 
Education, 1983c p. 48). As one policy-maker said, "bilingual education fosters mutual respect in all shades of good" (Journal, 1989, p. 54).

U.S. Policy-Makers, Educators, and Linguists Should Step Back Imaginatively and Ask "What If?"

If all this is so, then perhaps policy-makers, linguists, and educators in the United States should step back imaginatively and ask promoters of English-only in the 1990s (Fishman, 1989; Marshall, 1986; NCTE, 1989) "What if . . . Why . . . How did it start?" (Hymes, 1980, p. 71). For the enduring question, posed in Chapter I -- who uses what language with whom, when, where, and why? -- and the literature reviewed in Chapter II, show that speech communities differ in ways of speaking, in repertoires, and in the roles of language itself. While knowledge of the role of language in thought and culture or ethnicity, for bilinguals and monolinguals alike, is "only now being built in a sustained way" (Hymes, 1986, p. 40), Ferguson's studies literacy and language development in multilingual societies $(1959,1963$, 1968a, 1985)), Fishman's studies of language policy in education $(1967,1980,1985 \mathrm{~b}, 1989)$, and Hymes ethnographies of speaking (1961, 1974, 1980, 1986) model ways to "step back, imaginatively, in a way analogous to 'zero-budgeting'" and to ask questions (Hymes, 1980, p. 71).

What if educators were to "start where the child is . . linguistically . . . [to] develop the child's full potential"?

What if classrooms in multilingual, multicultural settings were to become natural places for ways of speaking, ways of knowing, and ways of learning?

What if educational leaders were to become a major force in addressing the complex problems of language acquisition, development, and assessment in curriculum and instruction, special education, and counseling? 
What if policy-makers were to validate the use of minority mother tongue and majority mother tongue in education as a "fundamental human right"? (Spolsky, 1978, p. 14).

What if concerned policy-makers, superintendents, principals, teachers, and parents involved themselves with concerned linguists and educational researchers, all adopting certain imperatives and certain goals?

What if attitudes about ethnolinguistic diversity changed? 


\section{EPILOGUE}

On April 27, 1981, Senator S. I. Hayakawa of California proposed an amendment to the U.S. Constitution declaring that English be made the "official language" of the United States (Marshall, 1986). Since that time, in every congressional session, similar resolutions have been introduced in both houses. None has been passed or even voted upon .... That is not to say the ELA is of little importance. It has affected the United States in two important ways. First it has encouraged the proposal for, and in many cases the enactment of state and municipal versions of the ELA, which declare English to be the official language and, in some instances, restrict the use of nonEnglish languages. In addition, it has opened up a loud and general debate not just about English and other languages in the United States but about immigration policy, racism, educational policy, and civil liberties (Judd, 1989, p. 27).

During the 100th Congress (1987-88), six ELA measures were introduced. One was a Senate bill (Senate Joint Resolution 13) and the other five were bills in the House of Representatives (House Joint Resolutions 13, 33, 83, and 656 and House Concurrent Resolution 129).

By now, sixteen states have passed some version of an official-English law, and many more are considering such legislation. These states and the dates of their legislation are listed below:

1988 Arizona
1987 Arkansas
1986 California
1988 Colorado
1986 Georgia
1988 Florida
1969 Illinois
1984 Indiana
1984 Kentucky
1987 Mississippi
1923 Nebraska
1987 North Carolina
1987 North Dakota
1987 South Carolina
1984 Temnessee
1981 Virginia


If a Federal English Language Amendment is ratified and federal and state legislation protection minority rights is challenged, the United States Supreme Court may be asked to interpret the validity of current legislation. Four federal statutes and their state counterparts advance specific rights that prior to their enactment were actively adbridged: (1) the Voting Rights Act of 1965 and its 1975 amendments; (2) the Court Interpreters Act of 1978; (3) the Equal Employment Opportunity Act of 1972; and (4) the Bilingual Education Act of 1968 and its 1974 amendments.

Constitutional rights that are endangered follow:

Fourth Amendment rights to confront wirnesses, to have assistance of counsel, and to understand the nature of the charges and the proceedings brought by the govermment against individual cirizens;

Fifth Amendment right to not be deprived of life, liberty, or property without due process of law;

Fourteenth Amendment rights to procedural due process and equal application of the law;

Fifteenth Amendment right to vote (Gonzalez, 1989, p. 51). 


\section{REFERENCES}

Alatis, J. E. (Ed.). (1980). Georgetown University round table on languages and linguistics 1980: Current issues in bilingual education. Washington: Georgetown University Press.

Alatis, J.E., Stern, H. H., \& Stevens, P. (Eds.). (1983). Georgetown University Round Table on languages and linguistics 1983: Applied linguistics and the preparation of second language teachers. Washington: Georgetown University Press.

Alexiou, M. (1982).। Diglossia in Greece. In W. Haas (Ed.), Standard languages: Spoken and written, (pp. 156-191). Manchester: Manchester University Press.

American Psychological Association. (1988). Publication manual of the American Psychological Association: Third edition. Washington DC: APA.

Anderson, A. B. (1988). German, Mennonite, and Hutterite communities in Saskatchewan: An inventory of sources. Saskatoon: University of Saskachewan for the Saskachewan German Council, Inc.

Anderson, L. C. (1983, October). Hutterite colonies: Toponymic identification. Paper presented at the Tenth Annual Historic Communal Societies Conference, New Harmony, Indiena.

Armytage, W, H. G. (1961). Heavens below: Utopian experiments in England: 1560-1960. Toronto: University of Toronto Press.

Ashworth, M, (1985). Beyond methodology: Second language teaching and the community. Cambridge: Cambridge University Press.

Bales, R. F. (1950). Interaction process analysis. New York: Holt, Rinehart and Winston.

Bales, R. F. (1970). Revision of interaction process analysis. In R. F. Bales, Personality and interpersonal behavior, (pp. 471-491). New York: Holt, Rinehart and Winston.

Bales, R. F. (1979). SYMLOG: A system for the multiple level observation of groups. New York: Free Press.

Bales, R. F., Strodtbeck, F., \& Roseborough, M. E. (1951). Channels of communication in small groups. American Sociological Review, 16, 461-468.

Bales, R. F., \& Borgatta, E. F. (1965). Interaction of individuals in reconstituted groups. In A. P. Hare, E. Borgatta, \& R. F. Bales (Eds.), Small groups, (pp. 379-395). New York: Wiley. 
Bales, R. F., \& Borgatta, E. F. (1965). Size of groups as a factor in the interaction profile. In A. P. Hare, E. Borgatta, \& R. F. Bales (Eds.), Small groups, (pp. 396-413). New York: Wiley.

Baron, D. (1990). The legal status of English in Illinois: Case study of a multilingual state. In H. A. Daniels, (Ed.), Not only' English: Affirming America's multilingual heritage, (pp. 13-26). Urbana: National Council of Teachers of English.

Beer, W. R. (1987). Toward a theory of linguistic mobilization. In W. R. Beer \& J. E. Jacob (Eds.), Language policy and national unity (pp. 217-235). Ottawa: Roman \& Allanheld, Publishers.

Beer, W. R., \& Beer, W. R. (1987). Introduction. In W. R. Beer \& J. E. Jacob (Eds.), Language policy and national unity (pp. 1-19). Ottawa: Roman \& Allanheld, Publishers.

Bennett, J. W. (1967). Hutterite brethren: The agricultural economy and social organization of a communal people. Stanford: Stanford University Press.

Bergen, J. J. (1950). The Mennonites of Manitoba and their schools from 1873-1924. Unpublished manuscript, University of Manitoba.

Berger, P. (1969). The sacred canopy: Elements of a sociological theory of religion. Garden City: Doubleday and Company.

Bernstein, B. (1986). The sociolinguistic approach to socialization; with some reference to educability. In J. J. Gumperz \& D. H. Hymes (Ed.), Directions in sociolinguistics: The ethnography of communication, (pp. 465-497). New York: Basil Blackwell.

Bickerton, D. (1983) Can English and Pidgin be kept apart? In C. Kennedy (Ed.), Language planning and language education (pp. 111-117). London: George Allen \& Unwin.

Blom, J-P., \& Gumperz, J. J. (1986). Social meaning in linguistic structures: Codeswitching in Norway life. In J. J. Gumperz \& D. H. Hymes (Ed.), Directions in sociolinguistics: The ethnography 'of communication, (pp. 407-434). New York: Basil Blackwell.

Borland International. (1988). PARADOX: Relational database. Scotts Valley: Borland International, Inc.

Borland International. (1989). QUATRO PRO: User's guide. Scotts Valley: Borland International, Inc.

Bortoni-Ricardo, S. M. (1985). The urhanization of rural dialect speakers: A sociolinguistic study in Brazil. Caumbridge: Cambridge University Press.

Bourhis, R. Y. (1984a). Social psychologiy and heritage language research: A retrospective view and future trends for Canada. In J. Cummins (Ed.), Heritage languages in Canada: Research perspectives (pp. 13-44). Report of the Heritage Language Research Conference convened by the Multiculturalism Program, Ottawa. 
Bourhis, R. Y. (Ed.). (1984b). Introduction: Language policies in multilingual settings. In R. Y. Bourhis (Ed.), Conflict and language planning in Quebec, (pp. 1-28). Avon: Multilingual Matters, Ltd.

Bourhis, R. Y. (Ed.). (1984c). Selected historical and linguistic events in Quebec and Canada. In R. Y. Bourhis (Ed.), Conflict and language planning in Quebec, (pp. 285293). Aivon: Multilingual Matters, Ltd.

Breton, R., Reitz, J.G. \& Valentine, V. F. (1980). Cultural boundaries and cohesion in Canada. Montreal: Institute for Research on Public Policy.

Britto, F. Diglossia: A study of the theory with application to Tamil. Washington: Georgetown University Press.

Burnby, B. (1987). Language for native, ethnic, or recent immigrant groups: What's the difference? TESL Canada Journal, 4, 9-27.

Byrce, G. (1893). One Canadian people. In In L. Clark (Ed.), The Manitoba school question: Majority rule or minority rights? (pp. 39-40). Toronto: Copp Clark Company.

Byrce, G. \& Ewart, J. S. (1889). Liberty vs. patriotic expediency. In In L. Clark (Ed.), The Manitoba school question: Majority rule or minority rights? (pp. 39-40). Toronto: Copp Clark Company.

Burnaby, B. (1987). Language for native, ethnic, or recent immigrant groups: What's the difference? TESL Canada Journal, 4, 9-27.

Canada Ministry' of State. (1988). Overview of new multiculturall directions. Ottawa: Department of the Secretary of State of Canada.

Clark, L. (1968). The Manitoba school question: Majority rule or minority rights? Toronto: Copp Clark Publishing company.

Clasen, C. P. (1972). Anabaptism: A social history, 1525-1618: Switzerland, A.lustria, Moravia, South and Central Germany. Ithaca: Cornell University Press.

Combs, M. C. \& Lynch, L. M. (1990). Disillusionment with oflicial English and the search for alternatives. In H. A. Daniels (Ed.), Not only English: Affirming A.merica's multilingual heritage, (pp. 99-108). Urbana: National Council of Teachers of English.

Conklin, N. F., \&\& Lourie, M. A. (1983). Policy and education in a multilingual society. In N. F. Conklin \& M. A. Lourie, A host of tongues: Language communities in the United States, (pp. 225-260). New York: Free Press.

Cook, R. (1969). The manle leaf forever: Essays on nationalism and politics in Canada. Toronto: Macillan of Canada.

Coulmas, F. (Ed.) (1984). Linguistic minorities and literacy. Berlin: Mouton Publishers. 
Cummins, J. (1984a, May). Educational linguistics and its sociological context in heritage language research. In J. Cummins (Ed.), Heritage languages in Canada: Research perspectives (pp. 45-62). Report of the Heritage Language Research Conference convened by the Multiculturalism Program, Ottawa.

Cummins, J. (1984b, May). Heritage language research conference recommendations. In J. Cummins (Ed.), Heritage languages in Canada: Research perspectives (pp. 96-107). Report of the Heritage Language Research Conference convened by the Multiculturalism Program, Ottawa.

Cummins, J. (1984). Linguistic minorities and multicultural policy in Canada. In J. Edwards (Ed.), Linguistic minorities, policies and pluralism (pp. 81-106). London: Academic Press.

Cummins, J. (1988). Position paper: The role and use of educational theory in formulating language policy. TESL Canada Journal, $\underline{5}, 11-19$.

Daniels, H. A. (1990a). The roots of language protectionism. In H. A. Daniels, (Ed.), Not only English: Affirming America's multilingual heritage, (pp. 3-12). Urbana: National Council of Teachers of English.

Daniels, H. A. (1990b). What one teacher can do. In H. A. Daniels (Ed.), Not only English: Affirming America's multilingual heritage, (pp. 121-130). Urbana: National Council of Teachers of English.

Davis, V. I. (1990). Paranoia in language politics. In H. A. Daniels (Ed.), Not only English: Affirming America's multilingual heritage, (pp. 71-76). Urbana: National Council of Teachers of English.

De Fehr, W., Ens, G., Epp, G., Janzen, H., Klassen, P., Siemens, L., \& Thiessen, J. (1974). Harvest: Anthology of Mennonite writing in Canada. Steinbach, MB: Mennonite Historical Society of Manitoba.

De Silva, M. W. W. (1982). Some consequences of diglossia. In W. Haas (Ed.), Standard languages: Spoken and written, (pp. 94-122). Manchester: Manchester University Press.

Dewalt, M. W., \& Troxell, B. (1989, March). Old Order Mennonite oneroom schools in Pennsylvania. A paper presented at the annual meeting of the American Educational Research Association, San Francisco.

Dil, A. S. (1971). Language structure and language use: Essays by Charles A. Ferguson. Stanford: Stanford University Press.

Dil, A. S. (1972a). The ecology of language: Essays by Einar Haugen. Stanford: Stanford University Press.

Dil, A. S. (1972b). Language in sociocultural change: Essays by Joshua A. Fishman. Stanford: Stanford University Press. 
Dil, A. (1989). Diglossia in Bangla: A study of shifts in the verbal repertoire of the educated classes in Dhaka, Bangladesh. In J. A. Fishman, A. Tabouret-Keller, M. Clyne, B. Krishnamurti, M. Abdulaziz (Eds.), The Ferguson impact: In honor of Charles A. Ferguson on the occasion of his 65th birthday (pp. 451-465). Berlin: Mouton de Gruyter.

Di Pietro, R. J. (1985). Culture and ethnicity in the bilingual classroom. In J. E. Alatis \& J. J. Staczek (Eds.), Perspectives on bilingualism and bilingual education, (pp. 144156). Washington: Georgetown University Press.

Dodson, C. J. (1989). Bilingualism and a sense of "peopleness." In J. A. Fishman, A. Tabouret-Keller, M. Clyne, B. Krishnamurti, M. Abdulaziz (Eds.), The Ferguson impact: In honor of Charles A. Ferguson on the occasion of his 65th birthday (pp. 387393). Berlin: Mouton de Gruyter.

Doerksen, V. \& Loewen, H. (Eds.). (1985). Collected works of Arnold Dyck, Volume I. Steinbach, MB: Manitoba Mennonite Historical Society.

Dow, J. R. (1988). Toward an understanding of some subtle stresses on language maintenance among the Old Order Amish of Iowa. International Joumal of the Sociology of Language, 69, 19-31. (From Linguistics and Language Behavior Abstracts, 1988, Abstract No. 8804190).

Drake, G. F. (1984). Problems of language planning in the United States. In J. Edwards (Ed.), Linguistic minorities, policies and pluralism (pp. 151-178). London: Academic Press.

Driedger, L. (1978). Ethnic identity in the Canadian mosaic. In L. Driedger (Ed.), The Canadian ethnic mosaic: A quest for identity (pp. 9-22). Toronto: McClelland and Steward.

Driedger, L. (1980). Fifty years of Mennonite identity in Winnipeg: A sacred canopy in a changing laboratory. In H. Loewen (Ed.), Mennonite images: Historical, cultural, and literary essays dealing with Mennonite issues (pp. 123-135).

Driedger, L. (1984, May). Sociology of language and Canadian heritage language research. In J. Cummins (Ed.), Heritage languages in Canada: Research perspectives (pp. 63-71). Report of the Heritage Language Research Conference convened by the Multiculturalism Program, Ottawa.

Driedger, L. (1990). Mennonites in Winnipeg. Winnipeg: Kindred Press.

Driedger, L., \& Hengstenberg, P. (1986). Non-official multilingualism: Factors affecting German language competence, use and maintenance in Canada. Canadian Ethnic Studies, $\underline{18}, 90-109$.

Ducharme, J-C. (1988). Minority language education rights. Ottawa: Canada Library of Parliament, Law and Government Division.

Durnford, R. C. (1978). The Heritage of Canada. Ottowa: Readers' Digest. 
Dyck, A. (1948). Koop enn Bua faore nao Toronto. North Kildonan, Manitoba: J. Regehr Printers.

Dyck, A. (1960). Koop enn Bua enn Dietschlaund. Steinbach, MB: Derksen Printers, Ltd.

Dyck, A. (1974). Lost in the steppes. (H.D. Dyck, Trans.). Steinbach, MB: Derksen Publishers.

Dyck, B. (1986, April 2). Pilot language program successful in Grunthal. The Carillion, p. 2 A.

Dyck, C. J. (Ed.). (1981). An introduction to Mennonite history: A popular history of the Anabaptists and the Mennonites. Scottdale: Herald Press.

Elliott, J. L. (1983). Canada: Two nations, many cultures? In J. L. Elliott (Ed.), Two nations, many cultures: Ethnic grouns in Canada (pp. 1-7). Scarborough: Prentice-Hall Canada, Inc.

Enninger, W. (1985a). Old Order Amish community schools and their insignificant meaning for the for the preservation of German linguistic varieties. Deutsche Sprache in Europa und Ubersee, 10, 201-217. (From Linguistic and Language Behavior Abstracts, 1985, 20, Abstract No. 8605395).

Enninger, W. (1986). Old Order Amish: Their repertory and use of signs as an object of study. Deutsche Sprache in Europa und Ubersee, 10, 137-152. (From Linguistics and Language Behavior Abstracts, 1986, 20, Abstract No. 8605395).

Enninger, W. (i985b). The Old Order Amish in Kent county, Delaware. Deutsche Sprache in Europa und Uhersee, 10, 11-20. (From Linguistics and Language Behavior Abstracts, 1985, 20, Abstract No. 8605394).

Enninger, W. (1988). On the maintenance of German-based varieties among the Old Order Amish. International Journal of the Sociology of Language, 69, 33-57. (From Linguistics and Language Behavior Abstracts, 1988, 22, Abstract No. 8804193).

Ens, A. (1978). Mennonite relations with governments: Westm Canada 1870-1925. Unpublished doctoral dissertation, University of Ottawa.

Ens, A. (1980). The public school crisis among Mennonites in Saskatchewan 1916-1925. In H. Loewen (Ed.), Mennonite images: Historical, cultural, and literary essays dealing with Mennonite issues (pp. 73-81). Winnipeg: Hyperion Press.

Ens Family Singers. (1988). Spos mott senn! (Cassette). Winnipeg.

Epp, F. H. (1974). Mennonites in Canada, 1786-1920: The history of a separate people. Toronto: Macmillan of Canada.

Epp, F. H. (1978). Problems of Mennonite Identity: A historical study. In L. Driedger (Ed.), The Canadian ethnic mosaic: A quest for identity (pp. 281-294). Toronto: McClelland and Stewart. 
Epp, F. H. (1982). Mennonites in Canada, 1920-1940: A people's struggle for survival. Toronto: Macmillan of Canada.

Epp, G. (1987). Mennonite immigration to Canada after World War II. Journal of Mennonite Studies, $5,108-119$.

Epp, R. (1987). Plautdietsch: Origins, development and state of the Mennonite Low German language. Journal of Mennonite Studies, 5, 61-72.

Epp-Thiessen, E. (1982). Altona: The story of a prairie town. Altona: D. W. Friesen \& Sons, Ltd.

Ervin-Tripp, S. M. (1967). An Issei learns English. Journal of Social Issues, 23, 78-89.

Ervin-Tripp, S. M. (1971). Sociolinguistics. In J. A. Fishman (Ed.), Advances in the sociology of language: Volume I: Basic concepts, theories, and problems: Alternative approaches, (pp. 15-91). The Hague: Mouton.

Ervin-Tripp, S. (1986). On sociolinguistic rules: alternation and co-occurrence. In J. J. Gumperz \& D. Hymes (Eds.), Directions in sociolinguistics: The ethnography of communication, (pp. 213-250). New York: Basil Blackwell.

Esman, M. J. (1987). The politics of official bilingualism in Canada. In J. E. Jacob \& W. R. Beer (Eds.), Language policy and national unity (pp. 45-66). Ottawa: Roman \& Allanheld, Publishers.

Ewert, J. S. (1894). The Manitoba school question. Toronto: The Copp Clark Publishing Company.

Fasold, R. W., and Shuy, R. W. (1974). Studies in language variation: Semantics, syntax, phonology, pragmatics, social situations, ethnographic approaches. Washington: Georgetown University Press.

Fasold, R. W. (1984). The sociolinguistics of society. Oxford: Basil Blackwell.

Ferguson, C. A. (1959). Diglossia. Word, 15, 325-340.

Ferguson, C. A. (1960). Linguistic diversity in South Asia. In A. S. Dil (Ed.), Language structure and language use (pp. 27-49). Stanford: Stanford University Press.

Ferguson, C. A. (1962a). Background to second language problems. In A. S. Dil (Ed.), Language structure and language use (pp. 61-69). Stanford: Stanford University Press.

Ferguson, C. A. (1962b). The language factor in national development. In A. S. Dil (Ed.), Language structure and language use (pp. 51-59). Stanford: Stanford University Press.

Ferguson, C. A. (1963a). Linguistic theory and language learning. In A. S. Dil (Ed.), Language structure and language use (pp. 97-111). Stanford: Stanford University Press. 
Ferguson, C. A. (1963b). Problems of teaching languages with diglossia. In A. S. Dil (Ed.), Language structure and language use (pp. 71-85). Stanford: Stanford University Press.

Ferguson, C. A. (1966a). Applied linguistics. In A. S. Dil (Ed.), Language stricture and language use (pp. 135-147). Stanford: Stanford University Press.

Ferguson, C. A. (1966b). National sociolinguistic profile formulas. In A. S. Dil (Ed.), Language structure and language use (pp. 157-183). Stanford: Stanford University Press.

Ferguson, C. A. (1968a). Contrasting patterns of literacy acquisition in a multilingual nation. In A. S. Dil (Ed.), Language structure and language use (pp. 249-275). Sttanford: Stanford University Press.

Ferguson, C. A. (1968b). Contrastive analysis and language development. In A. S. Dil । (Ed.), Language structure and language use (pp. 233-247). Stanford: Stanford University Press.

Ferguson, C. A. (1968c). Language development. In A. S. Dil (Ed.), Language structure and language use (pp. 220-232). Stanford: Stanford University Press.

Ferguson, C. A. (1985). Patterns of literacy in multilingual situations. In J. E. Alatis \& J. J. Staczek (Eds.), Perspectives on hilingualism and bilingual education, (pp. 133-141). Washington: Georgetown University Press.

Fetterman "D. M. (1989). Ethnography: Step by step. Newbury Park: Sage Publications.

Fishman, A. (1988). Amish literacy: What and how it means. Portsmouth: Heinemann.

Fishman, J. A. (Ed.). (1966). Language loyalty in the United States: The maintenance and perpetuation of non-English Mother Tongues by American ethnic and religious groups. London: Mouton \& Co.

Fishman, J. A. (1967). Bilingualism with and without diglossia; Diglossia with and without bilingualism. Journal of Social Issues, 23, 29-38.

Fishman, J. A. (1968a). Societal bilingualism: Stable and transitional. In A. S. Dil (Ed.), Language in sociocultural change: Essays by Joshua A. Fishman, (pp. 135-152). Stanford: Stanford University Press.

Fishman, I. A. (Ed.). (1968b). Readings in the sociology of language: Vollume I-II. The Hague: Mouton.

Fishman, J. A. (1971). Instruments. In R. L. Cooper, \& R. Ma (Ed.), Bilingualism in the Barrio (pp. 613-698). Bloomington: Indiana University.

Fishman, J. A. (1971). The sociology of language: An interdisciplinary social science approach to the study of language in society. In J. A. Fishman (Ed.), Adlvances in the sociology of language: Volume I: Basic concepts, theories, and problems: Alternative approaches, (pp. 217-380). The Hague: Mouton. 
Fishman, J. A. (1972a). Bilingual and bidialectal education: Anl attempt at a joint model for policy description. In A. S. Dil (Ed.), Language in sociocultural change: Essays by Joshua A. Fishman, (pp. 331-339). Stanford: Stanford University Press.

Fishman, J. A. (1972b). What has the sociology of language to isay to the teacher? In A. S. Dil (Ed.), Language in sociocultural change: Essays by Joshua A. Fishman, (pp. 340355). Stanford: Stanford University Press.

Fishman, J. A. (1980). Bilingualism and biculturism as individual and as societal phenomena. Journal of Multilingual and Multicultural development, 1, 3-15.

Fishman, J. A. (1983). Language modernisation and planning in comparison with other types of national modernisation and planning. In C. Kennedy (Ed.), Language planning and language education (pp. 37-54). London: George Allen \& Unwin.

Fishman, J. A. (1985a). Bilingual education in the United States under ethnic community auspices. In J. E. Alatis \& J. J. Staczek (Eds.), Perspectives on bilingualism and bilingual education, (pp. 170-179). Washington: Georgetown University Press.

Fishman, J. A. (1985b). The rise and fall of the ethnic revival. |Berlin: Mouton Publishers.

Fishman, J. A. (1986). Domains and the relationship between micro- and macrosociolinguistics. In J. J. Gumperz \& D. H. Hymes (Ed.), Directions in sociolinguistics: The ethnography of communication, (pp. 435-454). New York: Basil Blackwell.

Fishman, J. A. (1989). Language and ethnicity in minority sociolinguistic perspective. Clevedon: Multilingual Matters, Ltd.

Fishman, J. A., Cooper, R. L., \& Ma, R. (1971). Bilingualism in the Barrio. Bloomington: Indiana University.

Fishman, J. A., Tabouret-Keller, A., Clyne, M., Krishnamurti, B., Abdulaziz, M. (1989). The Ferguson impact: In honor of Charles A. Ferguson on the occasion of his 65th birthday. Berlin: Moutonn de Gruyter.

Foucher, P. (1985). Constitutional language rights of official-language minorities in Canada: A study of the legislation of the provinces and territories respecting education rights of official-language minorities and compliance with section 23 of the Canadian Charter of Rights and Freedoms. Ottawa: Minister of Supplies and Services of Canada.

Francescato, G. (1989). Bilingualism and diglossia in their mutual relationship. In J. A. Fishman, A. Tabouret-Keller, M. Clyne, B. Krishnarnurti, M. Abdulaziz (Eds.), The Ferguson impact: In honor of Charles A. Ferguson on the occasion of his 65 th birthday (pp. 395-401). Berlin: Mouton de Gruyter.

Francis, E. K. (1948). Mennonite institutions in early Manitoba: A study of their origins. Agricultural History, 22, 144-155.

Francis, E. K. (1955). In search of utopia. Altona: D. W. Friesen \& Sons. 
Frick, E. (1990). Metaphors and motives of language-restrictive movements. In H. A. Daniels, (Ed.), Not only English: Affirming America's multilingual heritage, (pp. 2736). Urbana: National Council of Teachers of English.

Friesen, J. (1985). Mennonites through the centuries: From the Netherlands to Canada. Steinbach, MB: Mennonite Village Museum Historical Series, Introductory Volume.

Friesen, P. (1980). The shunning. Winnipeg: Turnstone Press.

Friesen, V. C. (1988). The windmill turning: Nursery rhymes, maxims, and other expressions of Western Canadian Mennonites. Edmonton, AL: University of Alberta Press.

Frye. N. (1966). Varieties of literary utopias. In F. E. Manuel )Ed.), Utopias and utopian thought (pp. 25-49). Boston: Houghton Mifflin Company.

German-Canadian Congress (Manitoba), Inc. (1985, November 2). Report of the German-Canadian Community Development Conference. Winnipeg.

German-Canadian Congress (Manitoba), Inc. (1987, November 7). Report of the German-Canadian Awareness Conference. Winnipeg.

Goerzen, J. W. (1970). Low German in Canada: A study of Plautdietsch spoken by Mennonite immigrants from Russia. Published doctoral dissertation, University of Toronto.

Goetz, J. P., \& LeCompte, M. D. (1984). Ethnography and qualitative design in educational research. Orlando, FL: Academic Press, Inc.

Gonzalez, R. D. (1990). In the aftermath of the ELA: Stripping language minorities of their rights. In H. A. Daniels (Ed.), Not only English: Affirming America's multilingual heritage, (pp. 49-60). Urbana: National Council of Teachers of English.

Gonzalez, R. D., Schott, A. A., \& Vasquez, V. F. (1988). The English language amendement: Explaining myths. English Journal, 77, 24-30.

Goody, J. \& Watt, I. (1963). The consequences of literacy. In P. P. Giglioli (Ed.), Language and social context, (pp. 311-357). Middlesex: Penguin Books.

Gumperz, J. J. (1967). On the linguistic markers of bilingual communication. Journal of Social Issues, 23, 48-57.

Gumperz, J. J. (1968). The speech community. In P. P. Giglioli (Ed.), Language and social context, (pp. 219-231). Middlesex: Penguin Books.

Gumperz, J. J. (1985). Verbal strategies in multilingual communication. In J. E. Alatis \& J. J. Staczek (Eds.), Perspectives on bilingualism and bilingual education, (pp. 293307). Washington: Georgetown University Press. 
Gumperz, J. J., \& Hymes, D. (Eds.). (1986). Directions in sociolinguistics: The ethnography of communication. Oxford: Basil Blackwell.

Gumperz, J. J. (1986). Social network and language shift. In J. J. Gumperz, Discourse strategies, (pp. 38-58). Cambridge: Cambridge University Press.

Gumperz, J. J. (1986). Conversational code switching. In J. J. Gumperz, Discourse strategies, (pp. 59-99). Cambridge: Cambridge University Press.

Hamm. (1987). Continuity and change among Canadian Mennonite Brethren. Waterloo: Wilfrid Laurier University Press.

Haugen, E. (1957). Language and immigration. In A. S. Dil (Ed.), The ecology of language: Essays by Einar Haugen, (pp. 148-158). Stanford: Stanford University Press.

Haugen, E. (1962). Schizoglossia and the linguistic norm. In A. S. Dil (Ed.), The ecology of language: Essays by Einar Haugen, (pp. 148-158). Stanford: Stanford University Press.

Haugen, E. (1987). Blessings of Bahel: Bilingualism and language planning. Berlin: Mouton de Gruyter.

Heller, M. (1984, May). Anthropological perspectives on heritage language research. In J. Cummins (Ed.), Heritage languages in Canada: Research perspectives (pp. 72-82). Report of the Heritage Language Research Conference convened by the Multiculturalism Program, Ottawa.

Hiebert, C. (Ed.). (1974). Brothers in deed to brothers in need: A scrapbook about Mennonite immigrants from Russia 1870-1885. Newton, KS: Faith and Life Press.

Holloway, M. (1966). Heavens on earth: Utopian communities in America, 1690-1880. New York: Dover Press.

Hostetler, J. A. (1974). Hutterite society. Baltimore: Johns Hopkins Press.

Hostetler, J. A. (1980). Amish society. Baltimore: Johns Hopkins Press.

Hostetler, J. A. (1983a). Amish life. Baltimore: Johns Hopkins Press.

Hostetler, J. A. (1983b). Mennonite life. Baltimore: Johns Hopkins Press.

Huffines, M. L. (1986). Strategies of language maintenance and ethnic marking among Pennsylvania Germans. Language Sciences, $\underline{8}, 1-16$. (From Linguistics and Language Behavior Abstracts, 1986, 20, Abstract No. 8607096).

Hughes. E. C. (1970). The linguistic division of labor. In J. A. Fishman (Ed.), Advances in the sociology of language: Volume II: Contributions to the sociology of language, (pp. 296-309). The Hague: Mouton. 
Hymes, D. (Ed.). (1964). Language in culture and society: A reader in linguistics and anthropology. New York: Harper \& Row, Publishers.

Hymes, D. (1964). Toward ethnographies of communication: The analysis of communicative events. In P. P. Giglioli (Ed.), Language and social context, (pp. 2144). Middlesex: Penguin Books Ltd.

Hymes, D. (1967). Models of interaction of language and social setting. Journal of Sacial Issues, $\underline{23}, 8-27$.

Hymes, D. (1974). Foundations in sociolinguistics: An ethnographic approach. Philadelphia: University of Pennsylvania Press.

Hymes, D. (1980). Language in education: Ethnolinguistic essays. Washington, DC: Center for Applied Linguistics.

Hymes, D. (1980). Qualitative/quantitative research methodologies in education: a linguistic perspective. Language in education: Ethnolinguistic essays, (pp. 62-87). Washington, DC: Center for Applied Linguistics.

Hymes, D. H. (1983) Essays in the history of linguistic anthropology. Amsterdam: John Benjamins Publishing Company.

Hymes, D. H. (1985). Bilingual education: Linguistic vs. sociolinguistic bases. In J. E. Alatis \& J. J. Staczek (Eds.), Perspectives on hilingualism and bilingual education, (pp. 10-17). Washington, DC: Georgetown University Press.

Hymes, D. H. (1986). Models of the interaction of language and social life. In J. J. Gumperz \& D. H. Hymes (Ed.), Directions in sociolinguistics: The ethnography of communication, (pp. 35-71). New York: Basil Blackwell.

Inglehart, R. F., \& Woodward, M. (1967). Language conflicts and political community. In P.P. Giglioli (Ed.), Language and social context, (pp. 358-377). Middlesex: Penguin Books.

Isajiw, W. W. (1984, May). Keynote remarks: Three contexts for heritage language study. In J. Cummins (Ed.), Heritage languages in Canada: Research perspectives (pp. 10-12). Report of the Heritage Language Research Conference convened by the Multiculturalism Program, Ottawa.

Isajiw, W. W. (1985). Definitions of ethnicity. In R. M. Bienvenue \& J. E. Goldstein (Eds.), Ethnicity and ethnic relations in Canada: A book of readings (pp. 5-17). Toronto: Butterworths.

Jernudd, B. H., \& Rubin, J. (1971). Some introductory references pertaining to language planning. In J. Rubin \& B. H. Jernudd (Eds.), Can language be planned? Sociolinguistic theory and practice for developing nations, (pp. 311-323). Honolulu: University of Hawaii Press.

Joos. (1967). The five clocks: A linguistic excursion into the five styles of English usage. New York: Harcourt, Brace \& World, Inc. 
Joy, R. J. (1972). Languages in conflict: The Canadian experience. Toronto: McLelland and Stewart.

Judd, E. L. (1990). The fedral English language amendment: Prospects and perils. In H. A. Daniels, (Ed.), Not only English: Affirming America's multilingual heritage, (pp. 37-46). Urbana: National Council of Teachers of English.

Kanter, R. M. (1972). Commitment and community: Communes and utopias in sociological perspective. Cambridge: Harvard University Press.

Kanter, R. M. (1973). Communes: Creating and managing the collective life. New York: Harper \& Row Publishers.

Keeney, W. E. (1968). The development of Dutch Anabaptist thought and practice from 1539-1564.

Keller, R. A. (1982). Diglossia in German-speaking Switzerland. In W. Haas (Ed.), Standard languages: Spoken and written, (pp. 70-93). Manchester: Manchester University Press.

Keim, A. N. (Ed.). (1975). Compulsory education and the Amish: The right not to be modern. Boston: Beacon Press.

Klassen, D. H. (1989). Singing Mennonite: Low German songs among the Mennonites. Winnipeg: University of Manitoba Press.

Klatt, E., Roy, D, Klatt, G, \& Messinger, H. (1983). Lagenscheidt's standard German dictionary. New York: Langenscheidt.

Kloss, H. (1966). German-American language maintenance efforts. In J. A. Fishman (Ed.), Language lcyalty in the United States: the maintenance and perpetuation of NonEnglish Mother Tongues by American ethnic and religious groups, (pp. 206-252). London: Moulton \& Co.

Kribs, L. P. (1895). The Manitoba school question. Toronto: The Murray Printing Co.

Kuhn, T. S. (1962). The structure of scientific revolutions. Chicago: The University of Chicago Press.

Labov, W. (1966). The social stratification of English in New York City. Washington, DC: Center for Applied Linguistics.

Labov, W. (1972). Sociolinguistic patterns. Philadelphia: University of Pennsylvania Press.

Labov, W. (Ed.). (1980). Locating language in time and space. New York: Academic Press.

Lachepelle, R. \& Henripin, J. (1982). The demolinguistic situation in Canada: Past trends and future prospects. Montreal: Institute for Research on Public Policy. 
Lambert, R. D., and Freed, B. F. (Eds.). (1982). The loss of language skills. Rowley: Newbury House Publishers, Inc.

Laskey, M. J. (1976). Utopia and revolution: On the origins of a metaphor, or some illustrations of the problems of political temperament and intellectual climate and how ideas, ideals, and ideologies have been historically related. Chicago: University of Chicago Press.

Leopold, W. F. (1968). The decline of German dialects. In Readings in the sociology of language, (pp. 340-364). The Hague: Mouton.

Loewen, H. (Ed.). (1980). Mennonite images: Historical, cultural, and literary essays dealing with Mennonite issues. Winnipeg: Hyperion Press.

Loewen, H., \& Reimer, H. (1985). Origins and literacy development of CanadianMennonite Low German. Mennonite Quarterly Review, 59, 279-286.

Loewen, J. A. (1965). Language: Vernacular, Trade, or National? Practical Anthropology, 12, 97-105.

Loewen, J. A. (1968). Why minority languages persist or die. Practical Anthropology, $\underline{15}$, 8-15.

Loewen, J. A. (1975). Culture and human values: Christian intervention in anthropological perspective. Pasadena: William Carey Library.

Loewen, J. A. (1986, November). The German Language, Culture and the Faith. Dynamics of Faith and Culture in Mennonite Brethren History. Symposium conducted at the Centre for Mennonite Brethren Studies, Winnipeg.

Loewen, J. A. (1988). Onnse ieaaschte missionnsreis. Unpublished manuscript.

Loewen, R. (1982). Blumenort: A Mennonite community in transition, 1974-1982. Blumenort, MB: The Blumenort Mennonite Historical Society.

Louden, M. L. (1987). Bilingualism and diglossia. The case of Pennsylvania German. Leuven Bijdragen, 1987, 76, 17-36. (From Linguistics and Language Behavior Abstracts, 1987, 211, Abstract No. 8706506).

Mackey, W. F. (1970). A typology of bilingual education. In J. A. Fishman (Ed.), Readings in the sociology of language: Volume II: Contributions to the sociology of language, (pp. 413-432). The Hague: Mouton.

MacMaster, R. K. (1985). Land, piety, peoplehood: The establishment of Mennonite communities in America 1683-1790. Scottdale: Herald Press. (MEA Volume I.)

Mallea, J. R. (1984, May). Heritage languages, culture and schooling. In J. Cummins (Ed.), Heritage langunges in Canada: Research perspectives (pp. 83-95). Report of the Heritage Language Research Conference convened by the Multiculturalism Program, Ottawa. 
Maluzynsky, T. (1989, June). Language and culture showcased at Pantages Theatre. Your schools: River East School Division, p. 6.

Mallea, J. R. (1989). Schooling in a plural Canacia. Philadelphia: Multilingual Matters.

Manitoba Department of Education and Training. (1983a). Final report of the heritage language seminar held in Winnipeg on March 18, 19, 1983. Winnipeg: Manitoba Department of Education, Curriculum Development and Implementation Branch.

Manitoba Department of Education and Training. (1983b). Information booklet on the teaching of heritage languages in Manitoba. Winnipeg: Manitoba Department of Education, Curriculum Development and Implementation Branch.

Manitoba Department of Education and Training. (1988). English-German bilingual program: Grade six assessment. Winnipeg: Manitoba Department of Education, Curriculum Development and Implementation Branch.

Manitoba Department of Education and Training. (1989a). Heritage language programs in Manitoba. Winnipeg: Manitoba Department of Education, Curriculum Development and Implementation Branch.

Manitoba Department of Education and Training. (1989b). Funding of schools: 1989. Winnipeg: Manitoba Department of Education, Schools' Finance Branch.

Manitoba Department of Education and Training. (1989c). Basic German Language curriculum: Grades 1-12: Draft curriculum guide. Winnipeg: Manitoba Department of Education, Training Branch.

Manitoba Multicultural Secretariat. (1990). Manitoba's policy for a multicultural society: Building pride, equity and partnership. Winnipeg: Multicultural Secretariat.

Manitoba Parents for German Education. (1988). TRY hilingual education: An opportunity for children in your community to improve their English, German, and French. Winnipeg: Canada Minister of State, Multiculturalism, and Manitoba Department of Culture, Heritage and Recreation.

Manitoba Parents for German Education. (1988). Enrollment in German language programs. Winnipeg: MPGE.

Manuel F. E. and Manuel, F. P. (1979). Utopian thought in the Western World. Cambridge: Harvard University Press.

Marshall, D. G. (1986). The question of an official language: Language rights and the English Language Amendment. International Journal of Sociology, 60, 7-75.

McLeod, K. A. (1983). Multicultural education: A decade of development. In J. L. Elliott (Ed.) Two nations, many cultures: Ethnic groups in Canada (pp. 243-259). Scarborough: Prentice-Hall Canada, Inc. 
Milroy, J., \& Milroy, L. (1985). Authority in language: Investigating language prescription and standardisation. London: Routledge \& Kegan Paul.

Microsoft Corporation. (1989). Using microsoft word: Word processing program: Version 5.0. Redmond: Microsoft Corporation.

Milroy, L. (1986). Language and social networks (2nd ed.). New York: Basil Blackwell.

Milroy, L. (1987). Style-shifting and code-switching. In L. Milroy, Observing and analyzing natural languaga: A critical account of sociolinguistic method, (pp. 171-198). Oxford: Basil Blackwell.

Migus, P. M. (Ed.). (1975). Sounds Canadian: Languages and cultures in multi-ethnic society. Toronto: Peter Martin Associates Limited.

Mireau, E. (1965). A descriptive grammar of Ukrainian Low German. Unpublished doctoral dissertation, Indiana University, Bloomington.

Pattanayak, D. P. (1986). Educational use of the mother tongue. In B. Spolsky (Ed.), Language and education in multilingual settings, (pp. 5-15). San Diego: College-Hill Press.

Penalosa, F. (1981). Introduction to the sociology of language. Rowley: Newbury House Publishers, Inc.

Peters, E. (Tran.) (1980). Arnold Dyck's "Two Letters," "The Millionaire of Goatfield," "Runde Koake". Steinbach, MB: Derksen Printers.

Peters, J. (1985a). Mennonite private schools in Manitoba and Saskatchewan: 1874-1925. Steinbach, MB: Mennonite Village Museum Historical Series II.

Peters, J. (1985b). The Waisenamt: A history of Mennonite inheritance custom. Steinbach, MB: Mennonite Village Museum Historical Series I.

Plett, D. (1987). Profile of the Mennonite Kleine Gemeinde. Steinbach: DFP Publications.

Plett, T. (1986, February 26). Last-ditch pitch will be made for German program. The Carillion, p. 1A.

Pyles, T. and Algeo, J. (1982). The origins and development of the English language. New York: Harcourt Brace Jovanovich, Publishers.

Rand, B. (1988). Canadian Multiculturalism Act: What will it do? Manitoba Heritage Review, 4, 1-3.

Ratzlaff Swinney, J. (1989). Pilot study of a questionnaire on language and culture in a Mennonite community. Unpublished manuscript, Portland State University.

Redekop, C. (1989). Mennonite society. Baltimore: Johns Hopkins University Press. 
Redekop, J. H. (1987). A people apart: Ethnicity and the Mennonite Brethren. Winnipeg: Kindred Press.

Redekop, M. (1986). Through the Mennonite looking glass. In H. Loewen (Ed.), Why I am a Mennonite: Essays on Mennonite identity (pp. 226-253). Kitchener: Herald Press.

Reimer, A. (1980). The creation of Arnold Dyck's "Koop enn Bua" characters. In H. Loewen (Ed.), Mennonite Images: Historical, cultural, and literary essays dealing with Mennonite issues (pp. 257-266). Winnipeg: Hyperion Press.

Reimer, A. (1983). History of Mennonite Plautdietsch. In A. Reimer, A. Reimer, \& J. Thiessen (Eds.). A sackful of Plautdietsch: A collection of Mennonite Low German stories and poems (pp. 11-21). Winnipeg: Hyperion Press.

Reimer, A. (1985). My harp is turned to mourning. Winnipeg: Hyperion Press.

Reimer, A. (1987). Collected Works of Arnold Dyck, Volume II. Steinbach, MB: Manitoba Mennonite Historical Society.

Reimer, A. (1988). Collected Works of Arnold Dyck, Volume III. Steinbach, MB: Manitoba Mennonite Historical Society.

Reimer, A. (Trans.). (1980). "Koop and Bua go traveling." Journal of Mennonite Studies, I, 71-83.

Reimer, Al., Reimer, Anne., \& Thiessen, J. (Eds.). (1983). A sackful of Plautdietsch: A collection of Mennonite Low German stories and poems. Winnipeg: Hyperion Press.

Rein, K. (1988). The sociocultural and linguistic changes in Hutterite communities: Observations regarding a new visit. Schatzkammer, 13, 18-33. (From Linguistics and Language Behavior Abstracts, 1988, 22, Abstract No. 8801755).

Rempel, H. (1984). Kjenn jie noch Plautdietsch? A Mennonite Low German dictionary (revised edition). Winnipeg: Mennonite Literary Society.

River East School Division. (1989a). Schooll houndary maps. (Available from River East School Division No. 9, 589 Foche Street, Winnipeg.)

River East School Division. (1989b, May). Proposal for implementation of an enhanced German program at grade 10 level at River East Collegiate for September 1990. (Available from River East Curriculum Department, 589 Roch Street, Winnipeg, Manitoba, Canada R2K 2P7),

River East School Division. (1989c, June). Minutes: Senior high German advisory committee. (Available from River East Curriculum Department, 589 Roch Street, Winnipeg, Manitoba, Canada R2K 2P7).

Roger, M. (1983). An evaluation of the first two years of the English-German bilingual program. Winnipeg: Manitoba Department of Education, Curriculum Development and Implementation. 
Rose, M. (1988). Migration and ethnic persistence: A study of a rural Mennonite church. Mennonite Quarterly Review, 62, 167-176.

Rubin, J. (1971). Evaluation and language planning. In J. Rubin \& B. H. Jernudd (Eds.), Can language be planned: sociolinguistic theory and practice for developing nations (pp. 217-252). Honolulu: University of Hawaii Press.

Rubin, J. (1968). Language education in Paraguay. In J. A. Fishman, C. A. Ferguson, \& J. Das Gumpta (Eds.), Language problems in developing nations, (pp. 477-488). New York: Wiley.

Rubin, J. (1983). Bilingual education and language education. In C. Kennedy (Ed.), Language planning and language education (pp. 4-16). London: George Allen \& Unwin.

Rubin, J. (1985). Toward bilingual education for Paraguay. In J. E. Alatis \& J. J. Staczek (Eds.), Perspectives on bilingualism and bilingual education, (pp. 419-431). Washington, DC: Georgetown University Press.

Rudnyskyj, J. B. (1975). The problem of "unofficial" languages in Canada. In P. M. Migus (Ed.), Sounds Canadian: Languages and cultures in multi-ethnic society (pp. 29-41). Toronto: Peter Martin Associates.

Sagarin, E., \& Kelly, R. J. (1987). Polylingualism in the United States of America: A multitude of tongues amid a monolingual majority. In W. R. Beer \& J. E. Jacob (Eds.), Language policy and national unity (pp. 20-44). Ottawa: Roman \& Allanheld, Publishers.

Sampson, G. (1980). Schools of linguistic thought. Stanford: Stanford University Press.

Saville-Troike, M. (1982). The ethnography of communication: An introduction. Oxford: Basil Blackwell.

Saville-Troike, M. (1985). Cross-cultural communication in the classroom. In J. E. Alatis \& J. J. Staczek (Eds.), Perspectives on hilingualism and bilingual education, (pp. 330340). Washington, DC: Georgetown University Press.

Sawatzky, H. L. (1971). They sought a country: Mennonite colonization in Mexico. Berkeley: University of California Press.

Scheer, H. (1980). The Hutterite German dialect: A study in sociolinguistic assimilation and differentiation. Mennonite Quarterly Review, 54, 229-243.

Schegloff, E. A. (1971). Notes on a conversational practice: Formulating place. In P. P. Giglioli (Ed.), Language and social context, (pp. 95-135). Middlesex: Penguin Boolks.

Schegloff, E. A. (1986). Sequencing in conversational openings. In J. J. Gumperz \& D. H. Hymes (Ed.), Directions in sociolinguistics: The ethnography of communication, (pp. 346-380). New York: Basil Blackwell. 
Scotton, C. M. (1989). Diglossia and code switching. In J. A. Fishman, A. TabouretKeller, M. Clyne, B. Krishnamurti, M. Abdulaziz (Eds.), The Ferguson impact: In honor of Charles A. Ferguson on the occasion of his 65th birthday (pp. 403-415). Berlin: Mouton de Gruyter.

Searle, J. (1965). What is a speech act? In P. P. Giglioli (Ed.), Language and social context, (pp. 136-154). Middlesex: Penguin Books.

Sherzer, J., \& Damell, R. (1986). Outline guide for the ethnographic study of speech use. In J. J. Gumperz \& D. H. Hymes (Ed.), Directions in sociolinguistics: The ethnography of communication, (pp. 548-554). New York: Basil Blackwell.

Singh, U. N. (1989). Diglossia in Bangladesh and language planning problems. In J. A. Fishman, A. Tabouret-Keller, M. Clyne, B. Krishnamurti, M. Abdulaziz (Eds.), The Ferguson impact: In honor of Charles A. Ferguson on the occasion of his 65th birthday (pp. 431-449). Berlin: Mouton de Gruyter.

Skelton, O. D. (1921). The life and letters of Sir Willfrid Laurier. Toronto: Oxford University Press.

Sledd, J. (1990). Anglo-conformity: Folk remedy for lost hegemony. In H. A. Daniels (Ed.), Not only English: Affirming America's multilingual heritage, (pp. 87-98). Urbana: National Council of Teachers of English.

Smith, C. H. (1927). The coming of the Russian Mennonites: An episode in the settling of the last frontier, 1874-1884. Berne: Mennonite Book Concern.

Smitherman, G. (1990). The "mis-education of the Negro" -- and you too. In H. A. Daniels (Ed.), Not only English: Affirming America's multilingual heritage, (pp. 109120). Urbana: National Council of Teachers of English.

Spolsky, B. (Ed.). (1986). Language and education in multilingual settings. San Diego: College-Hill Press.

Stalker, J. C. (1988). Official English or English only. English Journal, 77, 18-23.

Stalker, J. C. (1990). Official English and the English profession. In H. A. Daniels (Ed.), Not only English: Affirming America's multilingual heritage, (pp. 61-68). Urbana: National Council of Teachers of English.

Statistics Canada. (1984). 1981 Census: Population: Manitoba: Catalogue 93-931. Ottawa: Ministry of Supply and Services, Canada.

Statistics Canada. (1987). 1986 Census: Profiles: Manitoba, Part I: Catalogue 94-113. Ottawa: Ministry of Supply and Services, Canada.

Statistics Canada. (1988). 1986 Census: Profiles: Manitoba, Part II: Catalogue 94-113. Ottawa: Ministry of Supply and Services, Canada. 
Stern, H. H. (1985). Bilingual schooling and foreign language education: Some implications of Canadian experiments in French immersion. In J. E. Alatis \& J. J. Staczek (Eds.), Perspectives on bilingualism and bilingual education, (pp. 395-418). Washington, DC: Georgetown University Press.

Stubbs, M. W. (Ed.). (1985). The other languages of England: Linguistic minorities project. London: Routledge \& Kegan Paul.

Stubbs, M. W. (1986). Educational linguistics. Oxford: Basil Blackwell.

Sundberg, T. J. (1988). The case against bilingualism. English Journal, 77, 16-17.

Swain, M. (1985). Bilingual education for the English-speaking Canadian. In J. E. Alatis \& J. J. Staczek (Eds.), Perspectives on bilingualism and bilingual education, (pp. 381394). Washington, DC: Georgetown University Press.

Thiessen, J. (1977). Mennonite Low German dictionary. Marburg: N.G. Elwert.

Toews, J. A. (1975). A history of the Mennonite Brethren Church: Pilgrims and pioneers. Hillsboro: Mennonite Brethren Publishing House.

Toews, J. B., Konrad, A. G., \& Dueck, A. (1985). Mennonite Brethren Church membership profile 1972-1982. [Special issue]. Direction, 14, (2).

Toews, P. (1986, November). Faith in culture and culture in faith: Mennonite Brethren entertaining expansive, separative and assimilative views about the relationship. Dynamics of Faith and Culture in Mennonite Brethren History. Symposium conducted at the Centre for Mennonite Brethren Studies, Winnipeg.

Tollefson, J. W. (1981). The language situation and language policy in Slovenia. Washington, DC: University Press of America, Inc.

Trudgill, P. (1983). Sociolinguistics: An introduction to language and society. New York: Penguin Books.

Trudgill, P. (Ed.). Applied sociolinguistics. London: Academic Press, Inc.

Urry, J. (1978). The language of faith and life. The closed and the open: Sncial and religious change amongst the Mennonites in Russia: 1789-1889 (pp. 382-399). Unpublished doctoral dissertation, Oxford University.

Urry, J. (1983). Who are the Mennonites? Archives Europeennes Sociologie, 24, 241-263.

Urry, J. (1989). From speech to literature: Low German and Mennonite identity in two worlds. Unpublished manuscript, Victoria University of Wellington, New Zealand.

Urry, J. (1989). None hut saints: The transformation of Mennonite life in Russia. Winnipeg: Hyperion Press. 
Villanueva, V. (1990). Solamente Ingles and Hispanics. In H. A. Daniels (Ed.), Not only English: Affirming America's multilingual heritage, (pp. 77-86). Urbana: National Council of Teachers of English.

Wald, P. (1989). Diglossia applied: Vernacular mixing and functional switching with Bangui Yakomas. In J. A. Fishman, A. Tabouret-Keller, M. Clyne, B. Krishnamurti, M. Abdulaziz (Eds.), The Ferguson impact: In honor of Charles A. Ferguson on the occasion of his 65th birthday (pp. 417-430). Berlin: Mouton de Gruyter.

Walker, A. G. H. (1984). Applied sociology of language: vernacular languages and education. In P. Trudgill (Ed.), Applied sociolinguistics, (pp. 159-202). London: Academic Press, Inc.

Wardhaugh, R. (1983). Language \& nationhond. Vancouver, BC: New Star Books.

Wardhaugh, R. (1986). An introduction to sociolinguistics. Oxford: Basil Blackwell.

Wardhaugh, R. (1987). Languages in competition: Dominance, diversity, and decline. Oxford: Basil Blackwell.

Wax, R. H. (1975). Doing fieldwork: Warmings and advice. Chicago: University of Clicago Press.

Whiteley, W. H. (1983). Sociolinguistic surveys at the national level. In C. Kennedy (Ed.), Language planning and language education (pp. 68-79). London: George Allen \& Unwin.

Wiens, D. (1973-74). From the village to the city (a grammar for the languages we are). Direction, 2, 98-149.

Wilkenson, L. (1988). SYSTAT: The system for statistics. Evanston: SYSTAT, Inc.

Williams, C. H. (1984). More than tongue can tell: Linguistic factors in ethnic separatism. In J. Edwards (Ed.), Linguistic minorities, policies, and pluralism (pp. 179-220). London: Academic Press.

Wundt, K. H. (1985). Pennsylvania German and the interpretation of "cultural themes" through various religious groups in Kent and Sussex counties, Delaware. Deutsche Sprache in Europa und Ubersee, 10, 20-25. (From Linguistic and Language Behavior Abstracts, 1985, 20, Abstract No. 8605475).

Zacharias, P. D. (1976). Reinland: An experience in community. Altona: D. W. Friesen \& Sons, Ltd. 
APPENDIX A

INSIDER-OUTSIDER INTERVIEW:

GUIDELINE, SPEAKER, QUESTIONS, AND CODES 


\section{INSIDER-OUTSIDER INTERVIEW \\ GUIDELINE, SPEAKER, QUESTIONS, AND CODES \\ SUMMER 1989}

\section{GUIDELINE}

1. Schedule a 1.5-hour to 2-hour "insider-outsider" interview in advance.

2. Take an interpreter, if necessary.

3. Approach the interview as a "speech act" or "speech event" -- not as a "survey".

4. Approach the interview as an "insider-outsider" in a Mennonite speech community:

(a) Study German language tradition in Mennonite ethnicity/religion;

(b) Study English languige trend in a Mennonite ethnicity/religion;

(c) Study language planning and policy-making in Canadian/Manitoba education.

5. Participate in and observe the interview as a speech act, as "SPEAKING".

6. Ask questions in the context of a speech act or speech event.

7. Note observations within 30 minutes of a speech act or speech event.

8. Code, enter, and analyze dita systematically later.

9. Follow-up and give feedback to participants within a reasonable time.

10. Be aware of the "observer's palmadox" all all times.

\section{SPEAKER}

1. Name?

2. Address?

3. City/Province/Zip?

4. Telephone?

5. Friend-of-friend?

6. Interview Date/Time?

\section{QUESTIONS AND CODES}

1. What is the year of your birth/age?

AGE1

\#_ = Age

2. What is your sex?

SEX2

$=0=M=M a l e$

$\square=1=F=$ Female 
3. What is the present address/locale insicle the Mennonite community in Manitoba?

$$
\begin{aligned}
\text { LOC3 } & \\
& =0=\mathrm{WI}=\text { Winnipeg } \\
& =1=\mathrm{KI}=\text { Kildonan } \\
& =2=\mathrm{ER}=\text { East Reserve } \\
& =3=\mathrm{WR}=\text { West Reterve } \\
& =4=\mathrm{OT}=\text { Other }
\end{aligned}
$$

4. How much time have I spent with you, spaaking/participating/observing?

$$
\stackrel{\text { TIME4 }}{{ }^{H}-}=\mathrm{H}=\text { Hours }
$$

5. How many generations have you/your folks lived in Manitoba?

$$
\begin{aligned}
& \text { GEN5 } \\
& =0=M=\text { Less than a generation } \\
& =1=1=\text { One generation } \\
& =2=2=\text { Two generations } \\
& \\
& =3=3=\text { Thre generations or more }
\end{aligned}
$$

6. What is your domestic stitus?

$$
\begin{aligned}
& \text { DoM6 } \\
& =0=\mathrm{S}=\text { Single } \\
& =1=\mathrm{M}=\text { Married } \\
& \\
& =2=\mathrm{D}=\text { Divoried/Separated/Widowed }
\end{aligned}
$$

7. What ethno-cultural tradition best describes your heritage?

$$
\begin{aligned}
\text { ETH7 } & \\
& =0=\mathrm{AM}=\text { Anabaptist-Mennonite } \\
& =1=\mathrm{AH}=\text { Anabiptist-Hutterite } \\
& =2=\mathrm{AA}=\text { Anabiptist-Amish } \\
& =3=\mathrm{PR}=\text { Protestant } \\
& =4=\mathrm{RC}=\text { Roman Catlolic } \\
& =5=\mathrm{JE}=\text { Jewish } \\
& =6=\mathrm{OT}=\text { Other }
\end{aligned}
$$

8. What ethno-cultural tradition besi describes your spouse's heritage?

ETH8

$$
\begin{aligned}
& =0=A M=\text { Anahiptist-Mennonite } \\
& =1=A H=\text { Anahaptist-Hutterite } \\
& =2=A A=\text { Anahaptist-Amish } \\
& =3=\mathrm{PR}=\text { Protestant } \\
& =4=\mathrm{RC}=\text { Catholic } \\
& =5=\mathrm{JE}=\text { Jewish } \\
& =6=\mathrm{OT}=\text { Other }
\end{aligned}
$$


9. What ethno-linguistic tradition best describes your family's heritage?

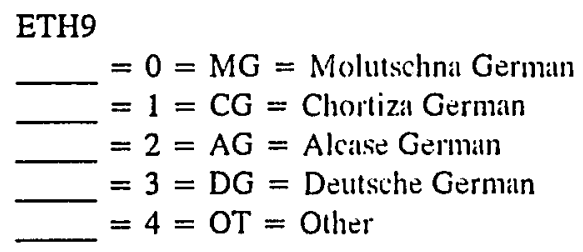

10. What ethno-linguistic tradition best describes your heritage?

ETH10

$\begin{aligned} & =0=\mathrm{KA}=\text { Kanidlier } \\ & =1=\mathrm{RU}=\text { Russlitender } \\ & =2=\mathrm{AN}=\text { Anglo-American } \\ & =3=\mathrm{DE}=\text { Deutschlitender }\end{aligned}$

11(-17). In what country were you (your folks) born?

LOC11-LOC17

$=0=\mathrm{C}=$ Canada

$=1=\mathrm{R}=$ Russia

$=2=\mathrm{G}=$ Germiny

$=3=\mathrm{P}=$ Poland

$=4=M=$ Mexico/Paraguay

$=5=\mathrm{U}=\mathrm{USA}$

$=6=\mathrm{I}=$ Italy

18(-24). What is the setting of your (your folk's) childhood home?

SET18-SET24

$=0=\mathrm{V}=$ Villatye (population under 1,000 )

$=1=\mathrm{T}=$ Town (population $=1,000-9,999$ )

$=2=\mathrm{C}=$ City (population $=10,000-99,999$ )

$=3=M=$ Metropolis (population = over 100,000)

25(-31). What occupation do you (your folks) pursue'?

WORK25-WORK31

$=0=\mathrm{S}=$ Student

$=1=\mathrm{F}=$ Farmer/homematker

$=2=\mathrm{C}=$ Clerk/Service worker

$=3=\mathrm{T}=$ Technician/Skilled worker

$=4=\mathrm{B}=$ Business/business manager

$=5=\mathrm{P}=$ Professionall/professional manager

$=6=\mathrm{E}=$ Executive/Corporate head

32(-38). What is the highest grade you (your folks) completed in school?

GRAD32-GRAD38

- 
39. What certificate/diploma best represtents your level of education?

GRAD39

$=0=A=$ Associate's certificate/Registered Nurse

$=1=\mathrm{B}=$ Bachelor's degree

$=2=M=$ Master's degree

$=3=\mathrm{D}=$ Doctor's degree

$=4=\mathrm{H}=$ High school diploma

40-81. Indicate preferred languige historically.

LANG40-LANG8I

Indicate a preference for $0=L G=$ Low German.

Indicate a preference for $1=H G=$ High German.

Indicate a preference for $2=E N=$ English.

Indicate a preference for $3=F R=F r e n c h$.

Indicate a preference for $4=R U=R u s s i a n$.

Indicate a preference for $S=O^{\circ}=$ Oher.

40(-46). What mother tongue do you (your folks) claim?

TONGUE40-TONGUE46

$=0=\mathrm{LG}=$ Low German

$\square=1=\mathrm{HG}=\mathrm{High}$ Germin

$\square=2=\mathrm{EN}=$ English

$=3=\mathrm{FR}=$ French

$=4=R U=$ Russian

$=5=\mathrm{OT}=$ Olher

47(-53). What home langulge did you (your folks) use in the folks' home?

HOMEL27-HOMEL53

$=0=\mathrm{LG}=\mathrm{Low}$ Germ:

$\square=1=\mathrm{HG}=$ High German

$=2=\mathrm{EN}=$ English

$=3=\mathrm{FR}=$ French

$=4=\mathrm{RU}=$ Rusisian

$=5=$ OT $=$ Other

54(-60). What school language did you (your folks) learn first?

SCH1L54-SCHIL60

$=0=\mathrm{LG}=$ Low Germ:m

$=1=\mathrm{HG}=$ High Germin

$=2=\mathrm{EN}=$ English

$=3=\mathrm{FR}=$ French

$=4=R U=R u$ si: un 
$=5=$ OT $=$ Other

61(-67). What school language dicl you (your folks) learn second?

SCH2L61-SCH2L67

$=0=\mathrm{LG}=$ Low German

$=1=\mathrm{HG}=$ High Germiın

$=2=\mathrm{EN}=$ English

$=3=\mathrm{FR}=$ French

$=4=\mathrm{RU}=$ Russian

$=5=$ OT $=$ Other

68(-74). What congregation/church langulge did you (your folks) use?

CONGL68-CONGL74

$=0=\mathrm{LG}=$ Low Germun

$=1=\mathrm{HG}=$ High German

$=2=\mathrm{EN}=$ Enılish

$=3=F R=$ French

$=4=\mathrm{RU}=$ Russian

$=5=\mathrm{OT}=$ Other

75(-81). What work language did you (your folks) use?

WORKL75-WORKL81

$=0=$ LG $=$ Low Germin

$=1=\mathrm{HG}=$ High Germin

$=2=E N=$ English

$=3=$ FR $=$ French

$=4=\mathrm{RU}=\mathrm{Rusii}$

$=5=\mathrm{OT}=$ Other

82(-91). What groups link you to the Mennonite community?

\section{NET82-NET91}

$=(82)$ Family groups

$=(83)$ Congregation/Kinship groups

$=(84)$ Educator/Language education occupation groups

$=(85)$ Parent/Language education occupation groups

$=(86)$ Policy-matier/Language education occupation groups

$=(87)$ Heritage/Culture voluntary groups

$=(88)$ Charity voluntary groups

$=(89)$ Literary/Art/Music voluntary groups

$=(90)$ Recreation voluntary groups

$=$ (91) Business/Economic voluntary groups

(82a-91a). How often do you associate with these groups?

$=0=\mathrm{D}=$ Daily

$=1=W=$ Weekly

$=2=M=$ Monthly 
$=3=\mathrm{A}=$ Annually

$=4=0=$ Occasionally

(82b-91b). What is the boundary of your group participation?

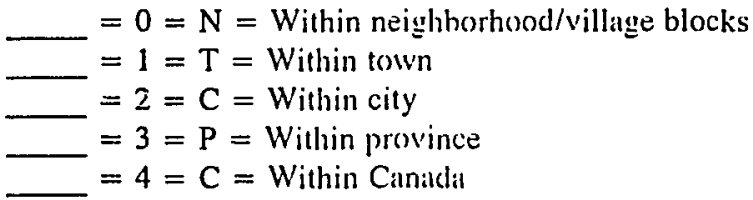

(82c-91c). What language do you prefer to use with these groups?

$=0=\mathrm{LG}=\mathrm{Low}$ German

$=1=\mathrm{HG}=$ High German

$=2=\mathrm{EN}=$ English

$=3=\mathrm{FR}=$ French

$=4=\mathrm{RU}=$ Russian

$=5=$ OT $=$ Other

92-126. Indicate preferred langulige lodayy.

LANG92A-LANG126F

Indicate a preference for $0=\mathrm{LG}=$ Low German.

Indicate a preference for $I=H G=H i g h$ German.

Indicate a preference for $2=E N=$ English.

Indicate a preference tor $3=F R=$ French.

Indicate a preference for $4=R U=$ Russian.

Indicate a preference for $5=O T=$ Other.

92(-99). In your home today, what lampluage do you use:

L92-99

$=(92)$ To talk will your spouse

$=(93)$ To talk with your children

$=(94)$ To talk with your parents

$=(95)$ To talk with your friends

$=(96)$ To talk with a stranger

= (97) To dream

$=(98)$ To read newspapers/hooks

$=(99)$ To write letlers

100(-106). In your folks' home lodily, what langulage do you use:

L100-106

$=(100)$ To talk with your pattents

$=(101)$ To talk will your sibling:

$=(102)$ To talk with your @ramdpatrents 
$=(103)$ To talk with your friends

$=(104)$ To talk with a stranger

$=(105)$ To read newspapers/books

$=(106)$ To write letters

107(-113). In the congregation today, what language do you use:

L107-113

$=(107)$ To talk in the foyer

$=(108)$ To talk in the sanctuary

$=(109)$ To talk in the social room/basernent

$=(110)$ To read the Bible

$=(111)$ To sing hymns

$=(112)$ To priay

$=(113)$ To talk with the pastor

14(-120). In primary/secondary school todiy, what language do you use:

\section{L114-120}

$=(114)$ To talk to children/play games on the playground

$=(115)$ To talk in the halls or coat room

$=$ (116) To talk to the teacher in language classes

$=(117)$ To talk to the latcher in other classes

$=(118)$ To read hooks/papers

$=(119)$ To write

$=(120)$ To talk to the teicher outside class

121(-126). In the Mennonite community Inday, what language do you use:

\section{L121-126}

$=(121)$ To talk in a village store

$=(122)$ To talk in a Steinbach store

$=(123)$ To talk in a Winkler store

$=(124)$ To talk in an Allona store

$=(125)$ To talk in a Kildonan silore

$=(126)$ To talk in a Winnipeg store

127. What books/newspapers/periodicals do you read??

LIT127

List examples open-endecily.

128. To what degree did langui!e used in your community change as a result of the ENGLISHONLY policy in Manitoba schools in 1890?

POL128

$=0=$ no chinges

$=1=$ small change

$=2=$ moderate chunge 
$=3=$ large change
$=4=$ no knowledge of change

List examples of change at home, at school, at work, in the congregation, in the community, open-endedly.

129. To what degree did language used in your community change as a result of the Englishonly policy in Manitoba schools in 1916?

POL129

$=0=$ no change

$=1=$ small chamge

$=2$ moderate change

$=3$ = large change

$=4=$ no knowledge of change

List examples of change at home, at school, at work, in the congregation, in the community, open-endedly.

130. To what degree did language used in your community change as a result of attitudes about Germans during World War ll?

POL130

$=0=$ no change

$=1=$ small change

$=2$ = moderate change

$=3$ = large change

$=4=$ no knowledge of change

List examples of change at home, at school, at work, in the congregation, in the community, open-endedly.

131. To what degree did languige used in your community change as a result of attitudes about Germans during World War Il?

POL131

$=0=$ no change

$=1=$ small change

$=2$ = moderate change

$=3$ = large change

$=4=$ no knowledge of change

List examples of change at home, at school, at work, in the congregation, in the community, open-endedly.

132. To what degree did langlalge used in your community change as a result of the Official Languages Act of 1969?

POL132

$=0=$ no change

$=1=$ small changes 
$=2$ = moderale change

$=\mathbf{3}=$ large change

$=4=$ no knowledge of change

List examples of change at home, at school, at work, in the congregation, in the community, open-endedly.

133. To what degree did language use in your community change as a result of the bilingual and multicultural school policies in the 1970s?

POL133

$=0=$ no change

$=1=$ small change

$=2=$ moderate change

$=3$ = large change

$=4$ = no knowledge of change

List examples of change at home, at school, at work, in the congregation, in the community, open-endedly.

134. To what degree did language use in your community change as a result of the Multicultural Act of 1988 ?

POL134

$=0=$ no change

$=1=$ small chinget

$=2=$ moderate changes

$=3$ = large change

$=4=$ no knowledge of change

List examples of change at home, at school, at work, in the congregation, in the community, open-endedly.

135. If you have ever found yourself in one or more of the following, and can recall it, answer the following question: "Who was using what language when, where, and why?

a. A time when you felt emharrassed to use your preferred language:

b. A time when you tried to change your speech:

c. A time when others tried to change your speech:

d. A time when you traveled and people commented on your speech:

e. A time when your German differed from your Mennonite companions:

f. A time when your words for tood, games, objects, differed from your associates:

g. A time when you tutored a child or a parent with in language:

h. A time when language was the subject of a conflict at home:

i. A time when langulge was the subject of conflict in the congregation:

j. A time when language was the subject of conflict at school:

k. A time when your preference for a language changed:

1. A time when your thild's preterence for a language changed:

m. A time when you telt proud to use your preferred language:

List examples open-endedly. 
APPENDIX B

INSIDER-OUTSIDER INTERVIEW:

LANGUAGE AND SOCIAL DATA ON FIFTY-SEVEN SPEAKERS 


\begin{tabular}{|c|c|c|c|c|c|c|c|c|c|c|c|c|c|c|c|c|c|}
\hline & & & & & & & & & & & & \multicolumn{6}{|c|}{ LANGUAGE AND SOCIAL DATA ON FIFT } \\
\hline & $\begin{array}{l}\text { Qi } \\
\text { AGE }\end{array}$ & $\begin{array}{l}\text { Q2 } \\
\text { SEX }\end{array}$ & $\begin{array}{l}03 \\
1.00\end{array}$ & OH & $\begin{array}{l}\text { Q5 } \\
\text { GEN }\end{array}$ & $\begin{array}{l}\text { QG } \\
\text { DOM }\end{array}$ & $\begin{array}{l}\text { Q7 } \\
\text { ETH }\end{array}$ & $\begin{array}{l}\text { Q8 } \\
\text { EIH }\end{array}$ & $\begin{array}{l}\text { Q9 } \\
\text { ETH }\end{array}$ & $\begin{array}{l}\text { Q10 } \\
\text { ETH }\end{array}$ & $\begin{array}{l}\text { Q11(-17) } \\
\text { LOC }\end{array}$ & Q18(-24) & $\mathrm{Q} 25(-31)$ & $\mathrm{Q} 32(-38)$ & Q39 & $040(-46)$ & $Q 47(-53)$ \\
\hline & & & & & & & & & & & LOC & SET & WORK & GRADE & GRAD & MOM-L & HOME-L \\
\hline \multicolumn{18}{|l|}{ Speaker } \\
\hline 1 & 42 & $M$ & $\mathrm{KI}$ & 6.0 & 3 & $M$ & $\mathrm{AM}$ & $\mathrm{AM}$ & $\mathrm{AG}$ & $\mathrm{KA}$ & $\mathrm{U}$ & $v$ & $p$ & $\mathrm{~T}$ & $M$ & 1.6 & Lo; \\
\hline 2 & 55 & $M$ & $\mathrm{KI}$ & 4.0 & M & $M$ & $\Lambda M$ & $\mathrm{AM}$ & $M C_{i}$ & RU & $R$ & $\mathrm{~T}$ & $p^{\prime \prime}$ & $\mathrm{l}$ & $D$ & I.Ci & L.G \\
\hline 3 & 51 & $M$ & KI & 2.0 & $M$ & $M$ & $\mathrm{AM}$ & $\mathrm{AM}$ & MG & RUI & $R$ & $T$ & $\mathrm{P}$ & $\mathrm{T}$ & $B$ & LG & HG \\
\hline 4 & 49 & $\mathrm{M}$ & $w !$ & 7.5 & 2 & $\mathbf{M}$ & AM & $\mathrm{AM}$ & $\mathbf{M G}$ & $\mathrm{KA}$ & $c$ & $\mathrm{r}$ & $\mathbf{p}$ & $\mathrm{r}$ & B & $I G$ & EN \\
\hline 5 & 42 & F: & $\mathrm{KI}$ & 8.5 & $M$ & D & $\mathrm{KC}$ & . & O' & OI & 1 & $\mathrm{~T}$ & $P$ & $\mathrm{~T}$ & $B$ & $\mathrm{lT}$ & $\mathrm{EN}$ \\
\hline 6 & 5) & $M$ & $w !$ & 8.0 & 3 & $M$ & $\mathrm{AM}$ & $\mathrm{AM}$ & $\mathrm{CG}$ & $\mathrm{KA}$ & $c$ & $v$ & $\mathrm{p}$ & $\mathrm{T}$ & D & I.G & $\mathrm{EN}$ \\
\hline 7 & 44 & $\mathrm{M}$ & $\mathrm{KI}$ & 5.5 & 1 & $M$ & $\mathrm{AM}$ & $\mathrm{AM}$ & MG & RU & c & $\mathrm{T}$ & $\mathrm{P}$ & $\mathrm{T}$ & D & $\mathrm{HIG}$ & $\mathrm{EN}$ \\
\hline 8 & (69) & $M$ & k1 & 4.0 & M & M & NM & $\mathrm{AM}$ & MG & RU & $\mathbf{R}$ & $\mathrm{v}$ & $P$ & $\mathrm{~T}$ & B & I.G & I.G \\
\hline 4 & 54 & $\mathrm{M}$ & WI & 3.0 & 3 & $M$ & AM & $\mathrm{AM}$ & CG & $\mathrm{KA}$ & $c$ & v & $\mathrm{p}$ & $\mathrm{T}$ & B & $1 . G$ & EN \\
\hline 10 & 50 & $M$ & WR & 7.0 & 2 & $M$ & AM & $\mathrm{AM}$ & $M G$ & $\mathrm{KA}$ & r: & $\mathrm{v}$ & $P$ & $r$ & $B$ & I. & I. \\
\hline 11 & 33 & $\mathrm{M}$ & $\mathrm{KI}$ & 0.5 & 1 & $s$ & $\mathrm{AM}$ & - & MG & $\mathrm{RU}$ & c & $M$ & $p$ & $T$ & B & IIG & EN \\
\hline 12 & 26 & $M$ & $\mathrm{KI}$ & 1.5 & 1 & $\mathrm{~S}$ & $\mathrm{PR}$ & . & DG & $\mathrm{DE}$ & C & $\mathrm{T}$ & $\mathrm{s}$ & $\mathrm{T}$ & B & $\mathrm{HG}$ & EN \\
\hline 13 & 40 & $\mathrm{~F}$ & WI & 2.5 & $M$ & $M$ & $\mathrm{RC}$ & RC & DG & $D F$ & $G$ & $M$ & $\mathbf{P}$ & $T$ & $\bar{B}$ & IIG & HG \\
\hline 14 & 49 & $\mathbf{M}$ & W! & 2.0 & $M$ & $M$ & $\mathrm{RC}$ & $\mathrm{RC}:$ & $D G$ & $D E$ & G & $M$ & p & $\mathrm{T}$ & $\mathrm{B}$ & HG & $H_{G}$ \\
\hline 15 & $\$ 2$ & $M$ & $\mathrm{Kl}$ & 2.0 & M & $M$ & $\mathrm{AM}$ & $\mathrm{AM}$ & $\mathrm{MG}$ & $\mathrm{RU}$ & $\mathrm{R}$ & v & $\mathrm{p}$ & $\dot{T}$ & D & $1 . G$ & LG \\
\hline 16 & 34 & $M$ & W] & 0.5 & 3 & $\mathrm{~s}$ & $\mathrm{AM}$ & - & CG & $\mathrm{KA}$ & c & $v$ & $\mathbf{s}$ & $T$ & B & I.G & EN \\
\hline 17 & 74 & $M$ & WI & 3.5 & $M$ & $M$ & $\mathrm{AM}$ & $\mathrm{AM}$ & MG & RU & $\mathbf{R}$ & v & $\mathrm{p}$ & $\mathrm{T}$ & D & I.G & 1.G \\
\hline 18 & 74 & $\mathrm{~F}$ & W! & 3.5 & $M$ & $\mathbf{M}$ & AM & $\mathrm{AM}$ & MG & RU & $\mathrm{R}$ & v & $\mathbf{P}$ & $\mathrm{T}$ & $M$ & I.G & LG \\
\hline 19 & 64 & $\mathbf{M}$ & WR & 3.0 & 1 & $M$ & $\mathrm{AM}$ & $\mathrm{AM}$ & $\mathrm{MG}$ & $\mathrm{RU}$ & $c$ & $v$ & $\mathrm{p}$ & $\mathrm{r}$ & B & 1.6 & LG \\
\hline 20 & 36 & $1:$ & $\mathrm{kl}$ & 36.0 & 2 & $M$ & AM & $\mathrm{AM}$ & $\mathrm{MG}$ & RU & C & $v$ & $\mathrm{~T}$ & $\mathrm{~T}$ & B & L, & EN \\
\hline 21 & 68 & $\mathbf{M}$ & kI & 1.5 & $M$ & $M$ & $\mathrm{AM}$ & $\mathrm{AM}$ & MG & $\mathrm{RU}$ & $\mathrm{R}$ & $v$ & $\mathrm{p}$ & $\mathrm{T}$ & $B$ & 1.6 & I.G \\
\hline 22 & 33 & $F$ & WI & 1.0 & 1 & $\mathrm{M}$ & $P R$ & PR & $D G$ & $\mathrm{DE}$ & c & $M$ & $\mathrm{~F}$ & $\mathrm{~T}$ & B & IIG & FN \\
\hline 23 & 41 & $M$ & I:R & 1.5 & 2 & $\mathbf{M}$ & $\mathrm{AM}$ & $\mathrm{AM}$ & CG & $\mathrm{KA}$ & $c$ & $v$ & $P$ & $\mathrm{I}$ & $D$ & I. & EN \\
\hline 24 & 32 & I: & WR & 4.5 & 2 & $\mathbf{S}$ & $A M$ & $\cdot$ & MG & $\mathrm{RU}$ & c & $v$ & $s$ & $T$ & B & LG & EN \\
\hline 25 & 35 & F & $\mathrm{KI}$ & 1.0 & 2 & $M$ & $\mathrm{AM}$ & $\Lambda \mathrm{M}$ & CG & $\mathrm{K} \Lambda$ & C & $\mathrm{T}$ & $\mathbf{T}$ & $\mathrm{T}$ & $\Lambda$ & EN & EN \\
\hline $2 k$ & 6.3 & $F$ & $\mathrm{KI}$ & 1.0 & 1 & $M$ & $\mathrm{AM}$ & $\mathrm{AM}$ & $\mathrm{CG}$ & $\mathrm{KA}$ & $c$ & $\mathrm{~T}$ & $\mathrm{~s}$ & $T$ & $\mathrm{~A}$ & I.G & FN \\
\hline 27 & 33 & $F$ & $\mathrm{KI}$ & 1.5 & 2 & $S$ & $\mathrm{AM}$ & $\cdot$ & MG & RU & c & $v$ & $\mathbf{S}$ & $s$ & H & EN & $\mathrm{EN}$ \\
\hline $2 k$ & 34 & $M$ & $\mathrm{I}: \mathrm{R}$ & 1.5 & 3 & $M$ & AM & $\mathbf{A M}$ & C.Ci & $\mathrm{KA}$ & $M$ & $v$ & $P$ & $s$ & $\mathrm{H}$ & I.Ci & IiGi \\
\hline 29 & 40 & I: & {$[: R$} & 1.0 & 1 & $M$ & $\mathrm{P} R$ & $P R$ & DO & DE & C & $M$ & B & $\mathrm{T}$ & B & $11 \mathrm{G}$ & EN \\
\hline 30 & 41 & $M$ & $\mathrm{I}: \mathrm{R}$ & 1.5 & 3 & $M$ & $\mathrm{AM}$ & $\mathrm{AM}$ & CG & $\mathrm{K} \wedge$ & $C$ & $v$ & $P$ & $\mathrm{~T}$ & B & L.G & EN \\
\hline 31 & 48 & $M$ & $\mathrm{KI}$ & 1.5 & 3 & $s$ & $\Lambda M$ & - & $\mathrm{CG}$ & $\mathrm{KA}$ & $r$ & $v$ & $\mathrm{P}$ & $\mathrm{T}$ & $\mathrm{B}$ & I.G & EN \\
\hline 32 & 47 & $\mathrm{~F}$ & I:R & 1.5 & 2 & $M$ & AM & $\mathrm{AM}$ & $c\left(c_{i}\right.$ & $\mathrm{KA}$ & c: & $v$ & C. & $s$ & $\mathrm{H}$ & 1.6 & IEN \\
\hline 33 & 25 & F & I:R & 1.5 & 1 & $M$ & $\mathrm{AM}$ & $A M$ & $\mathrm{MG}$ & $\mathrm{RU}$ & $c$ & $M$ & $\mathrm{P}$ & $\mathrm{T}$ & B & IIG & IEN \\
\hline 34 & 51 & M & $\mathrm{I}: \mathrm{R}$ & 2.5 & $M$ & $M$ & $A M$ & $\mathrm{AM}$ & MG & $\mathrm{RU}$ & $\mathrm{R}$ & $\mathrm{v}$ & $\mathrm{r}$ & $\mathrm{T}$ & B & L.G & EN \\
\hline .35 & 35 & $M$ & $\mathrm{IER}$ & 1.0 & 3 & $M$ & $\mathrm{AM}$ & $\mathrm{AM}$ & $\mathrm{C}(\mathrm{i}$ & $K_{A}$ & $c$ & v & $\mathrm{F}$ & $\mathrm{T}$ & $M$ & I.G & IN \\
\hline 36 & 38 & $\mathbf{M}$ & $\mathrm{I}: \mathrm{R}$ & 1.0 & 3 & $M$ & I'R & PR & O' & O' & $c$ & V & $\mathrm{P}$ & $\mathrm{I}$ & B & EN & IEN \\
\hline 37 & 45 & F & Kl & 1.0 & M & $M$ & $\mathrm{AM}$ & $\mathrm{AM}$ & $M C i$ & RU & C & $M$ & 3 & $\mathrm{~T}$ & B & 1.Gi & $\mathrm{HICi}$ \\
\hline . SS & 49 & $M$ & $\mathrm{I}: \mathrm{R}$ & 1.5 & 3 & $M$ & $\mathrm{AM}$ & $\mathrm{MM}$ & CG & $\mathrm{KA}$ & $c$ & $v$ & $\mathrm{P}$ & $\mathrm{T}$ & B & I.Gi & 1.6 \\
\hline 39 & 45 & $\mathrm{~F}$ & $I R$ & 1.5 & 3 & $\mathrm{~s}$ & AM & . & $\mathrm{C}(\mathrm{i}$ & $\mathrm{KA}$ & $r$ & v & $\mathrm{p}$ & $\mathrm{T}$ & $M$ & $1.6 i$ & IEN \\
\hline 40 & 65 & $\mathrm{~F}$ & I:R & 1.0 & 2 & D & MM & $\mathrm{AM}$ & CG & $\mathrm{KA}$ & $r$ & v & $\mathrm{F}$ & $\mathrm{P}$ & 11 & I.G & $\mathrm{INN}$ \\
\hline 41 & 49 & $M$ & $\mathrm{I}: \mathrm{K}$ & 1.5 & 1 & $M$ & $\mathrm{AM}$ & $\mathrm{AM}$ & Mri & KA & c & $v$ & I: & $\mathrm{T}$ & $\mathrm{k}$ & LG & LiN \\
\hline 42 & 43 & $M$ & WR & 2.0 & 3 & $M$ & $\mathrm{AM}$ & $A M$ & $\mathrm{CG}_{1}$ & $\mathrm{kA}$ & $c$ & $v^{\prime}$ & $\mathrm{p}$ & $T$ & B & $1 . G$ & IN \\
\hline 43 & 46 & $M$ & WR & 1.0 & 2 & $M$ & $\mathrm{AM}$ & $\mathrm{AM}$ & CG & $\mathrm{k} \wedge$ & $c$ & $v$ & $\mathrm{P}$ & $\mathrm{T}$ & B & L.G & I:N \\
\hline 44 & 6.5 & $M$ & KI & 3.0 & $M$ & $M$ & $\mathrm{AM}$ & $\mathrm{AM}$ & $\mathrm{Ag} ;$ & $\mathrm{RU}$ & $\mathrm{R}$ & $v$ & $\mathrm{p}$ & $T$ & $D$ & I.G & 1.6 \\
\hline 45 & 5.4 & $M$ & WI & 10 & 2 & $M$ & $A M$ & $\mathrm{AM}$ & $\mathrm{CG}^{\circ}$ & $\mathrm{KA}$ & $c^{\circ}$ & $v$ & $p$ & ' $\mathrm{l}$ & D & L.G & I:N \\
\hline 46 & 45 & $M$ & wi & 3.01 & 3 & $M$ & AM & $\mathrm{AM}$ & coi & KA & $r$ & $v$ & $p$ & $r$ & 1) & $1 .{ }_{1}$ & $I: N$ \\
\hline 47 & 42 & I & $\mathrm{k}_{1}$ & 1.5 & 1 & $M$ & AM & $\mathrm{MM}$ & $c_{i}$ & $\mathrm{RU}$ & $c$ & $v$ & $\mathrm{P}$ & $\mathrm{T}$ & is & $\mathrm{I}: \mathrm{N}$ & I:N \\
\hline 48 & 38 & F & K1 & 1.5 & 2 & $M$ & $\mathrm{AM}$ & $\mathrm{AM}$ & $\mathrm{CG}$ & RU & $c$ & $v$ & $\mathrm{p}$ & $\mathrm{T}$ & B & EN & EN \\
\hline 49 & 38 & $M$ & $\mathrm{KI}$ & 1.0 & 1 & $M$ & $A M$ & $A M$ & $\mathrm{CG}$ & RUI & $c$ & $v$ & $p$ & $T$ & n & $\mathrm{IN}$ & IN \\
\hline 50 & 266 & F: & WI & 2.0 & $M$ & $M$ & $\mathrm{HH}$ & $\mathrm{PR}$ & $D C_{i}$ & DF: & (i) & $M$ & $P$ & $\mathrm{~T}$ & 18 & Hiri & $\| K_{i}$ \\
\hline 51 & 39 & $M$ & $\mathrm{KI}$ & 2.0 & 3 & $M$ & $\mathrm{AM}$ & $A M$ & $\mathrm{co}$ & $\mathrm{KA}$ & $c$ & $v$ & $\mathrm{P}$ & $\mathrm{T}$ & 13 & EN & $\mathrm{I}: \mathrm{N}$ \\
\hline 52 & 28 & $\mathrm{~F}$ & k1 & 2.0 & 3 & $M$ & $\mathrm{AM}$ & $\mathrm{AM}$ & $\mathrm{CG}$ & $\mathrm{KA}$ & $c$ & $v$ & $\mathrm{~F}$ & s & H & LG & INN \\
\hline 53 & 48 & $M$ & $k 1$ & 2.0 & 3 & $M$ & $P R$ & $P R$ & $\mathrm{OH}$ & $o r$ & $c$ & $M$ & $\mathrm{p}$ & $\mathrm{J}$ & i) & FiN & $\mathrm{INN}$ \\
\hline 54 & 6.3 & $M$ & KJ & 151 & $M$ & $M$ & $A M$ & AM & MG; & RU & R & $v$ & $p$ & $\mathrm{r}$ & B & L.G & I.Gj \\
\hline 55 & 61 & I: & WR & 2.5 & 3 & $M$ & AM & $M M$ & CG & $\mathrm{KA}$ & $r$ & $v$ & IF & $\mathrm{s}$ & 11 & L.G & I. \\
\hline 56 & 45 & $F$ & WR & 2.0 & 1 & $M$ & $\mathrm{AM}$ & $\mathrm{AM}$ & MG; & RU & $c$ & $v$ & $T$ & $\mathrm{~S}$ & 11 & IIG & $\mathrm{IEN}$ \\
\hline 57 & 35 & $\mathrm{~F}$ & WI & 5.5 & 3 & $D$ & $A M$ & $\mathrm{AM}$ & $\mathrm{CH}$ & $\mathrm{KA}$ & $c$ & v & $s$ & $\mathrm{~T}$ & $M$ & FN & IIN \\
\hline
\end{tabular}





\section{LANGUAGE AND SOCIAL DATA ON FIFTY-SEVEN SPEAKERS}

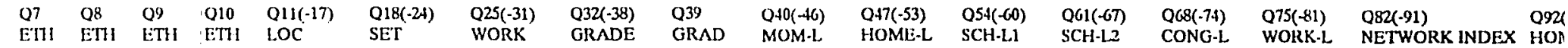

\begin{tabular}{|c|c|c|c|}
\hline$M M$ & $A M$ & $A G$ & $\mathrm{KA}$ \\
\hline$A M$ & $\Lambda M$ & $M G i$ & | RU \\
\hline$A M$ & $A M$ & MG & | RU \\
\hline$A M$ & $\mathrm{AM}$ & $M C ;$ & $\mathrm{KA}$ \\
\hline $\mathrm{KC}$ & - & OT & OT \\
\hline$A M$ & $A M$ & CG & $\mathrm{KA}$ \\
\hline$\wedge M$ & $\Lambda \mathrm{M}$ & MG & $\mathrm{RU}$ \\
\hline $\mathrm{AM}$ & $\Lambda M$ & $M G$ & $\mathrm{RU}$ \\
\hline$A M$ & $A M$ & $\mathrm{CG}$ & $\mathrm{KA}$ \\
\hline$\wedge M$ & $\mathrm{AM}$ & $M G i$ & KA \\
\hline$A M$ & · & MG & IRU \\
\hline PR & . & $\mathrm{DG}$ & DE \\
\hline $\mathrm{RC}$ & RC. & DG & DE: \\
\hline $\mathrm{RC}$ & $\mathrm{RC}$ & $D G$ & $\mathrm{DE}$ \\
\hline$A M$ & $\mathrm{AM}$ & MG & $R U$ \\
\hline$A M$ & . & CG & $\mathrm{K} \Omega$ \\
\hline$A M$ & AM & MGi & RU \\
\hline$A M$ & $A M$ & MG & $\mathrm{RU}$ \\
\hline$A M$ & $A M$ & $M G$ & $R U$ \\
\hline $\mathrm{AM}$ & AMI & $M G$ & RU \\
\hline$\wedge \mathrm{M}$ & $\mathrm{AM}$ & MG & RU \\
\hline $\mathrm{PR}$ & $P R$ & $\mathrm{DG}$ & DF \\
\hline$A M$ & $A M$ & $\mathrm{CG}$ & $K A$ \\
\hline$A M$ & - & $\mathrm{MG}$ & $\mathrm{RU}$ \\
\hline$\Lambda \mathrm{M}$ & $\Lambda \mathrm{M}$ & CG & $\mathrm{K} \Lambda$ \\
\hline$A M$ & $A M$ & $\mathrm{CG}$ & $\mathrm{KA}$ \\
\hline$\lambda M$ & - & MG & RU \\
\hline$A M$ & NA.1 & $C C_{i}$ & $k \wedge$ \\
\hline $\mathrm{PR}$ & PR & DG & $\mathrm{DE}$ \\
\hline$A M$ & $\Lambda M$ & CG & $\mathrm{KA}$ \\
\hline$A M$ & - & $\mathrm{CG}$ & $\mathrm{KA}$ \\
\hline $\mathbf{A M}$ & $\wedge M$ & $\mathrm{CCi}$ & $\mathrm{KA}$ \\
\hline $\mathrm{AM}$ & $\mathrm{AM}$ & $M G$ & $\mathrm{RU}$ \\
\hline$A M$ & $\Lambda \mathrm{M}$ & $M G$ & $\mathrm{RU}$ \\
\hline$A M$ & $\Lambda M$ & CG & $\mathrm{KA}$ \\
\hline l'K & $\mathbf{H} \mathbf{R}$ & OT & OI' \\
\hline $\mathrm{AM}$ & $\mathrm{AM}$ & $M C ;$ & $\mathrm{RU}$ \\
\hline$A M$ & $\Lambda M$ & $\mathrm{CG}$ & $\mathrm{K} \Lambda$ \\
\hline$\therefore M$ & . & $C(;$ & $\mathrm{KA}$ \\
\hline $\mathrm{AM}$ & AM & C. & $\mathrm{KA}$ \\
\hline$A M$ & $A M$ & Mri & $\mathrm{kA}$ \\
\hline AN & $A M_{1}$ & $\left.c^{\circ}\right)$ & $K A$ \\
\hline$A M$ & $\triangle M$ & $\mathrm{CG}$ & $\mathrm{k} \wedge$ \\
\hline$A M$ & $A M$ & MC; & RU \\
\hline $\mathrm{AM}$ & $A M_{1}$ & $C G$ & $\mathrm{KA}$ \\
\hline AM & $A B$ & $c\left(c_{i}\right.$ & $k A$ \\
\hline$\therefore M$ & $\operatorname{AM}$ & $\mathrm{CC}^{\circ}$ & RU \\
\hline$A M$ & $\Lambda \mathrm{M}$ & CG & RU \\
\hline $\mathrm{AM}$ & $A M$ & $\mathrm{CG}$ & RUI \\
\hline$r k$ & $\mathrm{PH}$ & $D_{x_{i}}$ & 1)1: \\
\hline$A M$ & $\mathrm{AM}$ & $\mathrm{CG}$ & $k_{s}$ \\
\hline$A M$ & $\Lambda M$ & $\mathrm{CG}$ & $\mathrm{k} \wedge$ \\
\hline$P R$ & PR & O't" & $O \mathrm{~T}$ \\
\hline$A M$ & $A M$ & $\mathrm{MGj}$ & RU \\
\hline$A M$ & $A M$ & $C C_{I I}$ & $K A$ \\
\hline$A M$ & $\Lambda M$ & $\mathrm{MG}$ & RU \\
\hline$A M$ & $\Lambda \mathrm{M}$ & $\mathrm{CH}$ & $\mathrm{K} A$ \\
\hline
\end{tabular}

$\begin{array}{lll}V & \mathrm{P} & \mathrm{T} \\ \mathrm{T} & \mathrm{P} & \mathrm{T} \\ \mathrm{T} & \mathrm{P} & \mathrm{T} \\ \mathrm{T} & \mathrm{P} & \mathrm{T} \\ \mathrm{T} & \mathrm{P} & \mathrm{T} \\ \mathrm{V} & \mathrm{P} & \mathrm{T} \\ \mathrm{T} & \mathrm{P} & \mathrm{T} \\ \mathrm{V} & \mathrm{P} & \mathrm{T} \\ \mathrm{V} & \mathrm{P} & \mathrm{T} \\ \mathrm{V} & \mathrm{P} & \mathrm{T} \\ \mathrm{M} & \mathrm{P} & \mathrm{T} \\ \mathrm{T} & \mathrm{S} & \mathrm{T} \\ \mathrm{M} & \mathrm{P} & \mathrm{T} \\ \mathrm{M} & \mathrm{P} & \mathrm{T} \\ \mathrm{V} & \mathrm{P} & \mathrm{T} \\ \mathrm{V} & \mathrm{S} & \mathrm{T} \\ \mathrm{V} & \mathrm{P} & \mathrm{T} \\ \mathrm{V} & \mathrm{P} & \mathrm{T} \\ \mathrm{V} & \mathrm{P} & \mathrm{T} \\ \mathrm{V} & \mathrm{T} & \mathrm{T} \\ \mathrm{V} & \mathrm{P} & \mathrm{T} \\ \mathrm{M} & \mathrm{F} & \mathrm{T} \\ \mathrm{V} & \mathrm{P} & \mathrm{T} \\ \mathrm{V} & \mathrm{S} & \mathrm{T} \\ \mathrm{T} & \mathrm{T} & \mathrm{T} \\ \mathrm{T} & \mathrm{S} & \mathrm{T} \\ \mathrm{V} & \mathrm{S} & \mathrm{S} \\ \mathrm{V} & \mathrm{P} & \mathrm{S} \\ \mathrm{M} & \mathrm{T} & \mathrm{T} \\ \mathrm{V} & \mathrm{P} & \mathrm{T} \\ \mathrm{V} & \mathrm{P} & \mathrm{T} \\ \mathrm{V} & \mathrm{V} & \mathrm{S} \\ \mathrm{M} & \mathrm{P} & \mathrm{T} \\ \mathrm{V} & \mathrm{F} & \mathrm{T} \\ \mathrm{V} & \mathrm{F} & \mathrm{T} \\ \mathrm{V} & \mathrm{P} & \mathrm{T} \\ \mathrm{M} & \mathrm{B} & \mathrm{T} \\ \mathrm{V} & \mathrm{P} & \mathrm{T} \\ \mathrm{V} & \mathrm{P} & \mathrm{T} \\ \mathrm{V} & \mathrm{F} & \mathrm{P} \\ \mathrm{V} & \mathrm{F} & \mathrm{T} \\ \mathrm{V} & \mathrm{P} & \mathrm{T} \\ \mathrm{V} & \mathrm{P} & \mathrm{T} \\ \mathrm{V} & \mathrm{P} & \mathrm{T} \\ \mathrm{V} & \mathrm{P} & \mathrm{T} \\ \mathrm{V} & \mathrm{P} & \mathrm{T} \\ \mathrm{V} & \mathrm{P} & \mathrm{T} \\ \mathrm{V} & \mathrm{P} & \mathrm{T} \\ \mathrm{V} & \mathrm{P} & \mathrm{T} \\ \mathrm{M} & \mathrm{P} & \mathrm{T} \\ \mathrm{V} & \mathrm{P} & \mathrm{T} \\ \mathrm{V} & \mathrm{F} & \mathrm{S} \\ \mathrm{M} & \mathrm{P} & \mathrm{T} \\ \mathrm{V} & \mathrm{P} & \mathrm{T} \\ \mathrm{V} & \mathrm{F} & \mathrm{S} \\ \mathrm{V} & \mathrm{T} & \mathrm{S} \\ \mathrm{V} & \mathrm{S} & \mathrm{T}\end{array}$

\begin{tabular}{|c|c|c|}
\hline $\mathrm{M}$ & 1.6 & LG \\
\hline D & I.G & L.G \\
\hline B & LG & $\mathrm{HG}$ \\
\hline B & $1 . G$ & EN \\
\hline B & $\mathrm{IT}$ & EN \\
\hline D & LG & EN \\
\hline D & $11 \mathrm{G}$ & EN \\
\hline B & 1.6 & I.G \\
\hline B & 1.G & EN \\
\hline B & 1.6i & $1.9 \mathrm{i}$ \\
\hline B & $I I G$ & EN \\
\hline B & HG & EN \\
\hline B & 110 & $\mathrm{HG}$ \\
\hline B & $116 \mathrm{i}$ & $\mathrm{HG}$ \\
\hline D & I.G & LG \\
\hline B & I.G & EN \\
\hline D & I.G & L.G \\
\hline$M$ & L.G & LG \\
\hline B & I.G & L.G \\
\hline B & l.c; & LN \\
\hline B & I.Gi & I.G \\
\hline B & 110 & EN \\
\hline $\mathrm{D}$ & L.G & EN \\
\hline B & LG & EN \\
\hline$\wedge$ & EN & EN \\
\hline$\wedge$ & I.G & FN \\
\hline 11 & EN & EN \\
\hline $\mathbf{H}$ & I.G & $\mathrm{HCi}$ \\
\hline B & 116 & EN \\
\hline B & I.G & EN \\
\hline B & 1.6 & EN \\
\hline $\mathrm{H}$ & $1.8 \mathrm{i}$ & $\mathrm{INN}$ \\
\hline $\mathbf{B}$ & 116 & EN \\
\hline B & L.G & EN \\
\hline $\mathbf{M}$ & 1.6 & IEN \\
\hline 18 & EN & EN \\
\hline$B$ & LG; & IIC; \\
\hline$B$ & 1.6 & I.G \\
\hline$M$ & $1.6 i$ & $\because \mathrm{N}$ \\
\hline 11 & I.G & FN \\
\hline$B$ & LGi & LN \\
\hline 13 & $1 . G$ & $I: N$ \\
\hline$B$ & I.G & IEN \\
\hline$D$ & I.G & I.G \\
\hline$D$ & l.ci & $\mathrm{N}$ \\
\hline D) & 1.8 & $I: N$ \\
\hline B & I:N & $I: N$ \\
\hline B & EN & EN \\
\hline$B$ & IN & $\mathrm{IIN}$ \\
\hline $\mathrm{B}$ & $11 \mathrm{G}$ & $H G i$ \\
\hline B & IEN & EN \\
\hline 11 & LG & EEN \\
\hline D) & $\mathrm{riN}$ & $\mathrm{IIN}$ \\
\hline B & 1.6 & L.G \\
\hline 11 & LG & 1.0 \\
\hline 11 & $11 \mathrm{G}$ & IEN \\
\hline & $\mathrm{IEN}$ & $\mathrm{FN}$ \\
\hline
\end{tabular}

\begin{tabular}{|c|c|}
\hline EN & $11 \mathrm{GG}$ \\
\hline IIGi & LN \\
\hline IIG & EN \\
\hline EN & IIG \\
\hline LN & $\mathrm{HG}$ \\
\hline EN & 110 \\
\hline EN & HG \\
\hline $\mathrm{HG}_{\mathrm{H}}$ & $\mathrm{HG}$ \\
\hline EN & $\mathrm{HG}$ \\
\hline H:N & $\mathrm{HC}$ \\
\hline EN & IIG \\
\hline EN & \\
\hline HG & IEN \\
\hline $\mathrm{HG}$ & $\mathrm{IEN}$ \\
\hline $\mathrm{HIG}_{\mathrm{H}}$ & EN \\
\hline EN & HG \\
\hline HG & $\mathrm{EN}$ \\
\hline HG & EN \\
\hline LiN & $116 \%$ \\
\hline EN & 116 \\
\hline $\mathrm{HG}$ & $\mathrm{INN}$ \\
\hline EN & IIG \\
\hline EN & . \\
\hline EN & 116 \\
\hline EN & 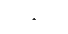 \\
\hline FEN & . \\
\hline EN & HG \\
\hline $\mathrm{HK}$ & \\
\hline EN & $11 \mathrm{G}$ \\
\hline EN & 116 \\
\hline $\mathrm{IIN}$ & $\mathrm{HC}$ \\
\hline I:N & $H H_{i}$ \\
\hline EN & IIG \\
\hline EN & HGG \\
\hline IIN & $\mathrm{II}_{\mathrm{i}}$ \\
\hline EN & $\mathrm{INK}$ \\
\hline I:N & $\| \mathrm{K}$ \\
\hline IEN & IKC \\
\hline I:N & III \\
\hline IN & 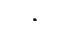 \\
\hline $\mathrm{IN}$ & $H_{G i}$ \\
\hline E:N & 110 \\
\hline EN & 110 \\
\hline IIG & IIN \\
\hline IIN & 1160 \\
\hline I:N & $\mathrm{HC}$; \\
\hline I:N & $1 \mathrm{IK}$ \\
\hline EN & 110 \\
\hline IN & $\mathrm{HG}_{\mathrm{H}}$ \\
\hline $\mathrm{HSi}$ & $\mathrm{I}: \mathrm{N}$ \\
\hline I:N & \\
\hline EN & 110 \\
\hline $\mathrm{I}: \mathrm{N}$ & ITR \\
\hline $11 \mathrm{Ki}$ & $\mathbb{I : N}$ \\
\hline EN & 116 \\
\hline EN & 116 \\
\hline I:N & \\
\hline
\end{tabular}

\begin{tabular}{|c|c|c|}
\hline HG-EN & LG.HG.EN & $1+1+1+1+1=5$ \\
\hline $11 \mathrm{G}$ & LG-HGG.EN & $1+1+1+1+1=5$ \\
\hline $\mathrm{HG}$ & HG-EN & $1+1+1+0+1=4$ \\
\hline IGG.EN & $\mathrm{EN}$ & $0+1+0+0+1=2$ \\
\hline$E$ & EN-FR & $1+0+0+0+0=1$ \\
\hline E & LG-HG.EN & $0+1+1+1+1=4$ \\
\hline HGG.EN & HG-EN & $1+1+1+1+1=4$ \\
\hline HG & L.G-HG-EN & $1+1+1+1+1=5$ \\
\hline IIG-EN & HG-EN & $0+1+1+0+1=3$ \\
\hline HGi-FN & I.G.HG.FN & $1+1+1+1+1=5$ \\
\hline IIG & HG-EN & $1+1+1+1+1=5$ \\
\hline IHG & HG-EN & $1+0+0+0+0=1$ \\
\hline HG & HG-EN & $0+0+1+0+0=1$ \\
\hline $\mathrm{HG}$ & $\mathrm{HG} \cdot \mathrm{EN}$ & $0+0+1+0+0=1$ \\
\hline HG & LG-HG-EN & $0+1+1+1+1=4$ \\
\hline HG.EN & HG.LG.EN & $0+1+1+1+0=3$ \\
\hline HG & HG-EN & $0+1+1+1+1=4$ \\
\hline $\mathrm{HG}$ & HG-EN & $0+1+1+1+1=4$ \\
\hline HG-EN & L.G-HGG.EN & $1+1+1+1+1=5$ \\
\hline HG-EN & LG-HCi-EN & $1+1+0+1+1=4$ \\
\hline 119 & $\mathrm{HG} \cdot \mathrm{EN}$ & $1+1+1+1+1=5$ \\
\hline lig & IIG-EN & $0+0+1+0+0=1$ \\
\hline HG.EN & $\mathrm{EN}$ & $1+1+1+1+1=5$ \\
\hline IIG.EN & IIG.EN & $0+1+0+1+1=3$ \\
\hline HG.EN & EN & $1+1+0+0+1=3$ \\
\hline HG.EN & EN & $1+1+0+0+1=3$ \\
\hline HG-EN & EN & $0+1+0+0+0=1$ \\
\hline $116:$ & HG-FiN & $1+1+1+1+1=5$ \\
\hline IIG-EN & IIG-EN & $1+0+0+1+0=2$ \\
\hline HGG-EN & LG-EN & $1+1+0+1+1=4$ \\
\hline HG-EN & I.G-EN & $1+1+1+1+1=5$ \\
\hline HGi-FN & HGi-I:N & $1+1+1+1+1=5$ \\
\hline $11 \mathrm{G}$ & IIG-EN & $1+1+1+1+1=5$ \\
\hline HG.EN & L.G.EN & $1+1+1+1+1=5$ \\
\hline HIGIEN & I.G.TN & $1+1+1+1+1=5$ \\
\hline I:N & $\mathrm{EN}$ & $1+0+1+1+0=3$ \\
\hline 110 & HG.LN & $1+1+1+1+1=5$ \\
\hline 11G.I:N & L.G.EN & $1+1+1+1+1=5$ \\
\hline IIGIEN & I.G.FN & $1+1+1+1+1=5$ \\
\hline IIG-EN & InN & $1+1+1+1+1=5$ \\
\hline $116 \cdot-\mathrm{EN}$ & LN & $1+1+1+1+1=5$ \\
\hline $1 / K+E N$ & LG-LN & $1+1+1+1+1=5$ \\
\hline IIG-EN & L.G.EN & $1+1+1+1+1=5$ \\
\hline 116 & I.GHIG.JN & $0+1+1+1+1=4$ \\
\hline HG.EN & LG-HGG.UN & $0+1+1+1+1=4$ \\
\hline HGi.EN & ICI-HGi.HN & $0+1+1+1+1=4$ \\
\hline IIGIEN & IIG.I:N & $1+1+1+1+1=5$ \\
\hline HG-EN & HG-EN & $1+1+1+1+1=5$ \\
\hline HG.I:N & HG.FN & $1+1+1+1+1=5$ \\
\hline $116 \mathrm{i}$ & HGi.I:N & $0+0+1+1+0=2$ \\
\hline$I: N$ & liN & $1+1+1+1+1=5$ \\
\hline HG.EN & IN & $1+1+1+1+1=5$ \\
\hline$I: N$ & $\mathrm{I}: \mathrm{N}$ & $0+0+1+0+0=1$ \\
\hline $116 i$ & HIG-LiN & $1+1+1+1+1=5$ \\
\hline $11 G \cdot \mathrm{LN}$ & LGIIG IN & $1+1+1+1+1=5$ \\
\hline 11G.EN & EN & $1+1+1+1+1=5$ \\
\hline 0 & & \\
\hline
\end{tabular}

$\mathrm{EN}$

LG

LG::

EN

EN

EN

EN

I.Gi

EN

EN

HG

LG.

LG

LG

LG

LG

EN

I.G

EN

EN

EN

EN

EN

HC
IIC

$\mathrm{EN}$

FA

in

IK

EP

T:P

LP

III

LC

Ii

it

El

El
El

I.

bi

(i)

[:

I:

H

l:

E 



\section{DATA ON FIFTY-SEVEN SPEAKERS}

\begin{tabular}{|c|c|c|c|c|c|c|c|c|c|c|c|}
\hline $\begin{array}{l}\text { O40(-4G) } \\
\text { MOM-L }\end{array}$ & $\begin{array}{l}\text { Q47(-53) } \\
\text { HOME-L }\end{array}$ & $\begin{array}{l}\text { Q54(-60) } \\
\text { SCH-L1 }\end{array}$ & $\begin{array}{l}\text { QGl }(-67) \\
\mathrm{SCH} \cdot \mathrm{L} 2\end{array}$ & $\begin{array}{l}\text { QG8(-74) } \\
\text { CONG-L }\end{array}$ & $\begin{array}{l}\text { Q75(-81) } \\
\text { WORK-L }\end{array}$ & $\begin{array}{l}\text { Q82(-91) } \\
\text { NE'TWORK INDEX }\end{array}$ & $\begin{array}{l}\text { Q92(-99) } \\
\text { HOME-L }\end{array}$ & $\begin{array}{l}\text { Q100(-100) } \\
\text { FOLKS-L }\end{array}$ & $\begin{array}{l}\text { Q107(-113) } \\
\text { CONG-L }\end{array}$ & $\begin{array}{l}\text { QHH }(-120) \\
\text { SCH-L }\end{array}$ & $\begin{array}{l}\text { Q121(-126) } \\
\text { TRADE-L }\end{array}$ \\
\hline 1.6 & L.G & LiN & $\mathrm{Hig}$ & HG-EEN & LG-HG-EN & $1+1+1+1+1=5$ & EN & LG-EN & HG.EN & EN-I.G-HG & EN \\
\hline 1.6; & LG & 116 & IEN & IIG & LG.IIG-EN & $1+1+1+1+1=5$ & LG & LG & IIG & EN-LG-HG & EN \\
\hline LG & IIG & $11 G$ & EN & HG & HG.EN & $1+1+1+0+1=4$ & LG-HG & LG-HG & HG & EN-HG & EN \\
\hline I.G & EN & ENN & $I I G$ & IIG.EN & EN & $0+1+0+0+1=2$ & EN & LG & IIG-EN & EN-FR & EN \\
\hline lit & $\mathrm{ISN}$ & IEN & $\mathrm{HO}$ & $\mathrm{E}$ & EN-FR & $1+0+0+0+0=1$ & EN & I' & EN & EN-FR & EN \\
\hline I.G & EN & EN & IIG & $\mathbf{E}$ & LGHHG-EN & $0+1+1+1+1=4$ & EN & LG & IG-EN & EN-LG.]IG & LN \\
\hline IIG & EN & EN & $11 G$ & HG.EN & $\mathrm{HG} \cdot \mathrm{EN}$ & $1+1+1+1+1=4$ & EN & IIG & HG.EN & EN-HG & EN \\
\hline 1.6 & I.G & $H G$ & $\mathrm{HG}$ & HG & IGHGGEN & $1+1+1+1+1=5$ & I.G & I.G & HG-EN & EN-LG-HG & $\mathrm{FN}$ \\
\hline I.G & EN & EN & $11 G$ & HG-EN & HG-EN & $0+1+1+0+1=3$ & EN & LG & HG & EN-LG-HG & EN \\
\hline I. $(i$ & l.6i & FN & $H G$ & HG.FN & 1.G-HGi $\mathrm{FiN}$ & $1+1+1+1+1=5$ & I.G & I.G & HG-FN & FiN-IGHCH & $\mathrm{HN}$ \\
\hline 110 & EN & EN & $11 G$ & IIG & HG.EN & $1+1+1+1+1=5$ & EN & IIG & IIG·EN & EN-IIG & EN \\
\hline HG & EN & EN & $\cdot$ & $11 \mathrm{G}$ & HG.EN & $1+0+0+0+0=1$ & EN & HG & HG.EN & EN-HG & EN \\
\hline 116 & HG & 116 & EN & HG & HG-EN & $0+0+1+0+0=1$ & $\mathrm{HG}$ & HG & $\mathrm{HG}$ & I:N HG & $I: N$ \\
\hline IIC & $\mathrm{HIG}$ & $\mathrm{HG}$ & $\mathrm{EN}$ & $\mathrm{HG}$ & HG-EN & $0+0+1+0+0=1$ & $\mathrm{HG}$ & $\mathrm{HG}$ & HG & $\mathrm{EN} \cdot \mathrm{HG}$ & $\mathrm{EN}$ \\
\hline $1 . G$ & LG & HG & $\mathrm{EN}$ & HG & LG-1IG-EN & $0+1+1+1+1=4$ & LG-EN & LG & HG-EN & EN-LG-HIG & EN \\
\hline I.G & EN & EN & $11 \mathrm{G}$ & HG-EN & HG-LG-EN & $0+1+1+1+0=3$ & LG.EN & LG & HG-EN & EN-LG- $\cdot$ IG & EN \\
\hline I.G & 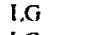 & HG & EN & $\mathrm{HCS}$ & $\mathrm{HG} \cdot \mathrm{EN}$ & $0+1+1+1+1=4$ & LG-HG & I.G & HG & EN-IG-HC & EN \\
\hline L.G & LG & HG & EN & $\mathrm{HG}$ & HG.EN & $0+1+1+1+1=4$ & LG.HG & LG.HG & $\mathrm{HG}$ & EN-LG-HG & EN \\
\hline 1.6 & LG & $\mathrm{EN}$ & $11 \mathbf{G}$ & IIG-EN & LG.HG.LN & $1+1+1+1+1=5$ & LG & LG & HG.EN & EN-LG-HG & $\mathrm{EN}$ \\
\hline 1.6 & $\mathrm{LN}$ & LN & $11 G$ & IIG-EN & LG.IIG-EN & $1+1+0+1+1=4$ & EN & LG.EN & EN & EN-LG-IIG & EN \\
\hline 1.6 & $1 . G$ & $H G$ & $\mathrm{IEN}$ & HG & HG-EN & $1+1+1+1+1=5$ & I.G.HG & I.G & $\mathrm{HG}$ & EN-LG.HG & EN \\
\hline 116 & EN & $\mathrm{EN}$ & IIG; & IIC & IIG.EN & $0+0+1+0+0=1$ & EN & $11 G$ & HIG & EN-HG & EN \\
\hline LG & EN & LN & $\cdot$ & $H G \cdot E N$ & EN & $1+1+1+1+1=5$ & $\mathrm{EN}$ & LG-EN & EN & EN & EN \\
\hline LG & EN & EN & $11 G$ & IIG.EN & 11G-EN & $0+1+0+1+1=3$ & EN & LG.EN & EN & EN-LG-IIG & EN \\
\hline EN & EN & EN & & HG-EN & EN & $1+1+0+0+1=3$ & EN & EN & EN & EN & EN \\
\hline I.6 & FN & TEN & . & HGTEEN & $\mathrm{FEN}$ & $1+1+0+0+1=3$ & EN & I.G.F.N & EN & EN & EN \\
\hline EN & EN & EN & $\mathrm{HG}$ & HG-EN & EN & $0+1+0+0+0=1$ & EN & EN & EN & EN-HG & EN \\
\hline l.ci & IIC; & 116 & $\cdot$ & HCi & $\mathrm{HG}-\mathrm{H}: \mathrm{N}$ & $1+1+1+1+1=5$ & $\mathrm{HCi}$ & I. (i & HCi & BN.HG & FN \\
\hline 119 & EN & EN & $\| G$ & IIG-IEN & HG.EN & $1+0+0+1+0=2$ & IIG-EN & 116 & EN & EN-IIG & EN \\
\hline LG & EN & EN & $\mathrm{HG}$ & HG-EN & LG.EN & $1+1+0+1+1=4$ & $\mathrm{EN}$ & LG & EN & EN-LG·HG & EN \\
\hline I.G & ז:N & T:N & 110 & IIG-IEN & I.G.FEN & $1+1+1+1+1=5$ & EN & I.G & EN & EN-I.G.HG & EN \\
\hline 1.6 & IIN & $\mathrm{I} N \mathrm{~N}$ & $\mathrm{HCi}$ & HCi-FN & $H(C \cdot I \div N$ & $1+1+1+1+1=5$ & $\mathrm{INN}$ & I.ri & HG-FEN & FN-I.G-HG & FEN \\
\hline 116 & EN & EN & II $;$ & IIG & IIG-EN & $1+1+1+1+1=5$ & HG-EN & HG & IIG & EN-HG & EN \\
\hline $1 . G$ & EN & EN & $11 G$ & IIG-EN & LG.EN & $1+1+1+1+1=5$ & EN & I.G.HG & EN & EN.FR & EN \\
\hline 1,6 & $\mathbf{I}: \mathbf{N}$ & ISN & $\mathrm{HC}$ & IIG-TEN & I.G.FEN & $1+1+1+1+1=5$ & EN & I.G & T:N & EN-L.G & EN \\
\hline EN & $\mathrm{EN}$ & LN & $\mathrm{lk}$ & I:N & EN & $1+0+1+1+0=3$ & $\mathrm{EN}$ & I:N & EN & EN-HG & EN \\
\hline I. $(i$ & $\mathrm{HG}$ & liN & $\| G i$ & IICi & $\mathrm{HG} \cdot \mathrm{ESN}$ & $1+1+1+1+1=5$ & HG-LN & L.G.HG & HG & EN-HG & EN \\
\hline l. ( ; & 1.5 & EN & IICi & IIG-T:N & I.G.EN & $1+1+1+1+1=5$ & LG & I.G & IIG.IEN & EN-TR & EN \\
\hline I. $(i$ & $\mathrm{IN}$ & IEN & HC; & IICI.EN & I.G.FN & $1+1+1+1+1=5$ & $\mathrm{ISN}$ & I.6i & HG;.I:N & EN-I.G & FN \\
\hline I.G & FiN & IEN & - & HCI-EN & $\mathrm{I}: \mathrm{N}$ & $1+1+1+1+1=5$ & EN & I.G & EN & EN & EN \\
\hline 1.(i & $\mathrm{LN}$ & IIN & 116 & $\| 16,-E N$ & IEN & $1+1+1+1+1=5$ & IEN & LG & $\mathrm{LN}$ & EN.FFR & EiN \\
\hline L.G & IIN & EN & Iici & $\| K+1 E N$ & L.G.LN & $1+1+1+1+1=5$ & EN & 1.6 & EN & EN-FIR & EN \\
\hline L.G & IEN & EN & $H G$ & IIG.EN & I.G.t:N & $1+1+1+1+1=5$ & EN & LG & EN & EN-FR & EN \\
\hline I.G & I. $C$ & 116 & $\mathrm{FN}$ & IIG & I.G-HIG-I:N & $0+1+1+1+1=4$ & $1 . G .116$ & I.G.HO & 116 & EN-LG.HG & EN \\
\hline 1.6; & I:N & $1 \mathrm{~N}$ & $\mathrm{HCi}$ & $H G-K E N$ & LG.HIC-ISN & $0+1+1+1+1=4$ & $\mathrm{ISN}$ & I.G & I:N & EN-LG-HG & EN \\
\hline I. & $\mathrm{I} N$ & $I: N$ & 116 & $\| G G-H N$ & I.GilfGilt:N & $0+1+1+1+1=4$ & $\mathrm{I}: \mathrm{N}$ & I. & $H(i-H) N$ & FEN-I.G-HG & FN \\
\hline$I: N$ & $I: N$ & I:N & $1 \mathrm{lG}$ & $1 / C ; . L N$ & HGHEN & $1+1+1+1+1=5$ & lEN & I.G.IEN & $\| G-L N$ & EN-HG & EN \\
\hline EN & EN & EN & HG & IIG-EN & HG.EN & $1+1+1+1+1=5$ & $\mathrm{EN}$ & LG-EN & EN & EN.HG & $\mathrm{EN}$ \\
\hline IIN & $\Gamma: N$ & T:N & 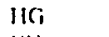 & IIG-FEN & HG-FEN & $1+1+1+1+1=5$ & $\Gamma: N$ & I.C.F.N & $\mathrm{IIN}$ & I:N.HG & EN \\
\hline 116 & $116 i$ & $116 i$ & $\mathrm{H}: \mathrm{N}$ & $116 i$ & $H G i \cdot N$ & $0+0+1+1+0=2$ & $\mathrm{HC}$ & IICi & $\mathrm{HC}$ & FANHG & $\mathrm{F}: \mathrm{N}$ \\
\hline EN & $\mathfrak{l}: \mathrm{N}$ & I:N & $\cdot$ & IN & IiN & $1+1+1+1+1=5$ & $I: N$ & E:N & IEN & EN & EN \\
\hline LG & EN & I:N & 116 & IIG.EN & IEN & $1+1+1+1+1=5$ & EN & I.G.E.N & HG.EN & EN & EN \\
\hline $\mathbf{I : N}$ & $\mathrm{I}: \mathrm{N}$ & I:N & {$[\cdot R$} & $\mathrm{I}: \mathrm{N}$ & $\mathrm{I}: \mathrm{N}$ & $0+0+1+0+0=1$ & EN & $\mathrm{INN}$ & I:N & FN-ITR & riN \\
\hline $1 . G$ & I.G & IIG & $\operatorname{t:N}$ & $11 G$ & HG-E:N & $1+1+1+1+1=5$ & LGH-HICi & LG-HG & $\mathrm{HC}$ & L:N-FK & $\mathrm{LN}$ \\
\hline 1.6 & 1.6 & IEN & 110 & IIC.EN & LG-IIG-IN & $1+1+1+1+1=5$ & LG & LG & IIG-EN & EN-LGHG & $\mathrm{EN}$ \\
\hline 116 & $I: N$ & EN & 116 & IIG.EN & EN & $1+1+1+1+1=5$ & EN & $11 G$ & IEN & IEN & EN \\
\hline FN & I:N & I:N & $11 \mathrm{C}$ & HGI-IEN & IEN & $0+1+0+0+1=2$ & TEN & I.G.F.N & IEN & EN.HG & EN \\
\hline
\end{tabular}



APPENDIX C

DATA SUMMARY 
Mennonite Speech Community (Q7) and Speech Fields (Q3)

Mother Tongue (Q40) / Home Language(Q92) -- Past / Present

Mother Tongue Clui:ns -- Passt

7 speakers $=$ English

4 speakers $=$ High German

37 speakers $=$ Low Germann

48 speakers $=$ Total in speech community

7 speakers $=$ English

2 speakers $=$ High Germim

21 speakers $=$ Low Germain

30 speakers $=$ Total in urban speech tield

2 speakers $=$ High German

16 speakers $=$ Low Germin

18 speakers $=$ Total in rural speech field

Home Lamgungere Use -- Present

31 speakers $=$ English

1 speaker = High Germam

6 speakers $=$ Low Germ:

2 speakers $=$ English and High German

2 speakers $=$ English and Low German

6 speakers $=$ Low German and High German

48 speakers $=$ Totill in speech corimumity

19 speakers $=$ English

2 speakers $=$ Low German

1 speaker = English and High German

2 speakers $=$ English and Low German

6 speakers $=$ Low Germin : and High Germari

30 speakers $=:$ Total in urban speech field

12 speakers $=$ Englisl

1 speaker = High Germin

4 speakers $=$ Low Germa:m

1 speaker = English and High German

18 speakers $=$ Total in rural speech field 
Mennonite Speech Community (Q7) and Speech Fields (Q3) Congregation Language (Q68)/(Q107) -- Past / Present

Congregation Lamguage Use -- Past

2 speakers $=$ English

13 speakers $=$ High Germun

33 speakers $=$ High German shifi to English

48 speakers $=$ Totil in speech community

2 speakers $=$ Enylish

11 speakers $=$ High Germun

17 speakers $=$ High German shift to English

30 speakers $=$ Totil in urbin speech tield

2 speakers $=$ High Germinn

16 speakers $=$ High Germun shift to English

18 speakers $=$ Totill in rural speech field

Congregation Langunge Use -- Prescent

20 speakers $=$ English

11 speaker $=$ High German

17 speakers $=$ Low Germun shift to English

48 speakers $=$ Total in spech community

10 speakers $=$ English

9 speakers $=$ Low German and High German

11 speakers $=$ High German shift to English

30 speakers $=$ Tot:il in urban speech field

10 speakers $=$ English

2 speaker $=$ High German

6 speakers $=$ High German shift (o) English

18 speakers $=$ Total in rural speech tield 
Mennonite Speech Community (Q7) and Speech Fields (Q3)

School Language (Q54)/(Q1/4) -- Patst / Present

School Language Uise -- Past

38 speakers $=$ English

10 speakers $=$ High German

48 speakers $=$ Total in speech community

21 speakers $=$ English

9 speakers $=$ High German

30 speakers $=$ Totil in urhatn speech field

17 speakers $=$ English

1 speaker $=$ High German

18 speakers $=$ Totill rutal speech field

School Languerge Usie -- Presemt

7 speakers $=$ English

11 speakers = English-High German hilingualism

23 speakers $=$ English and High German/Low German diglossia

7 speakers $=$ English-French bilingualism

48 speakers $=$ Total in speech community

4 speakers $=$ English

9 speakers $=$ Englisl-High German bilingualism

15 speakers $=$ English and High German/Low German diglossia

2 speakers $=$ Englisth-French bilingualism

30 speakers $=$ Totil in urbitn speech field

3 speakers $=$ English

2 speaker $=$ English-High German hilingualism

8 speakers $=$ English and High German/Low German diglossia

5 speakers $=$ English-French bilingualism

18 speakers $=$ Total rutal speech field 


\section{DATA SUMMARY}

Mennonite Speech Community (Q7) and Speech Repertoires (Q10)

Mother Tongue (Q40) / Home Language (Q92) -- Past / Present

Mother Tongue Claims -- Past

3 speakers $=$ English

23 speakers $=$ Low German

26 speakers $=$ Total with Kanadier identity

4 speakers $=$ English

4 speakers = High German

14 speakers $=$ Low Germ:

22 speakers $=$ Total with Russlatender identity

2 speakers $=$ English

6 speakers $=$ High Germaın

1 speaker = Italian

9 speakers $=$ Total with non-Mennonite identity

Home Languenge Usie -- Prescint

21 speakers $=$ Englisill

1 speaker = High German

3 speakers = Low German

1 speaker = Low German shift to English

26 speakers $=$ Total with Kantadier identity

10 speakers $=$ English

3 speakers $=$ Low German

2 speakers $=$ High German shift to English

1 speaker $=$ Low Germun shift to English

6 speakers $=$ Low German and High German

22 speakers $=$ Total with Russlatender identity

5 speakers $=$ English

3 speaker $=$ High German

1 speaker = High German shift to English

9 speakers $=$ Total with non-Mennonite identity 
DATA SUMMARY

Mennonite Speech Community (Q7) and Speech Repertoires (Q10) Congregation Langulate (Q68)/(Q107) -- Past / Present

Congregation Language Use -- Past

2 speakers $=$ English

1 speaker $=$ High Germin

23 speakers $=$ High German shift to English

26 speakers $=$ Tot:t with Kinnadier identity

12 speakers $=$ High German

10 speakers $=$ High German shift to English

22 speakers $=$ Totil with Russilander identity

3 speakers $=$ English

5 speakers $=$ High German

1 speaker = High German shift to English

9 speakers $=$ Total with non-Mennonite identity

Congregation Lamguage Use -- Presem

13 speakers $=$ English

2 speakers $=$ High Germ:ın

11 speakers $=$ High Germuan shift to English

26 speakers $=$ Tolial with Kanadier identity

7 speakers $=$ English

9 speakers $=$ High Germin

6 speakers $=$ High Germ:tn shift to English

22 speakers $=$ Tot:tl with Russlatender identity

4 speakers $=$ English

4 speakers $=$ High German

1 speakers $=$ High German shift to English

9 speakers $=$ Totill with non-Mennonite identity 
Mennonite Speech Community (Q7) and Speech Repertoires (Q10) School Languige (Q54)/(Q114) -- Past / Present

School Language Usie -- Past

25 speakers $=$ English

1 speaker $=$ High Germin

26 spenkers $=$ Total with Kanadier identity

13 speakers $=$ English

9 speakers $=$ High German

22 speakers $=$ Total with Russlitender identity

6 speakers $=$ English

3 speakers $=$ High Germin

9 speakers $=$ Total with non-Mennonite identity

School Languuge Use -- Presem

6 speakers $=$ English

2 speakers $=$ English-High German bilingualism

13 speakers = English anl Higl/ German/Low German diglossia

5 speakers $=$ English-French hilingualism

26 speakers = Total wilh Kanadier identity

1 speakers $=$ English

9 speakers = English-High German bilingualism

2 speakers = English-French bilingualism

10 speakers = English and Higlı German/Low German diglossia

22 speakers $=$ Total with Russilander identity

7 speakers $=$ English-High German bilingualism

2 speakers $=$ English-French hilingutilism

9 speakers $=$ Total wilh non-Mennonite identity 
APPENDIX D

NETWORK INDEX SORT 


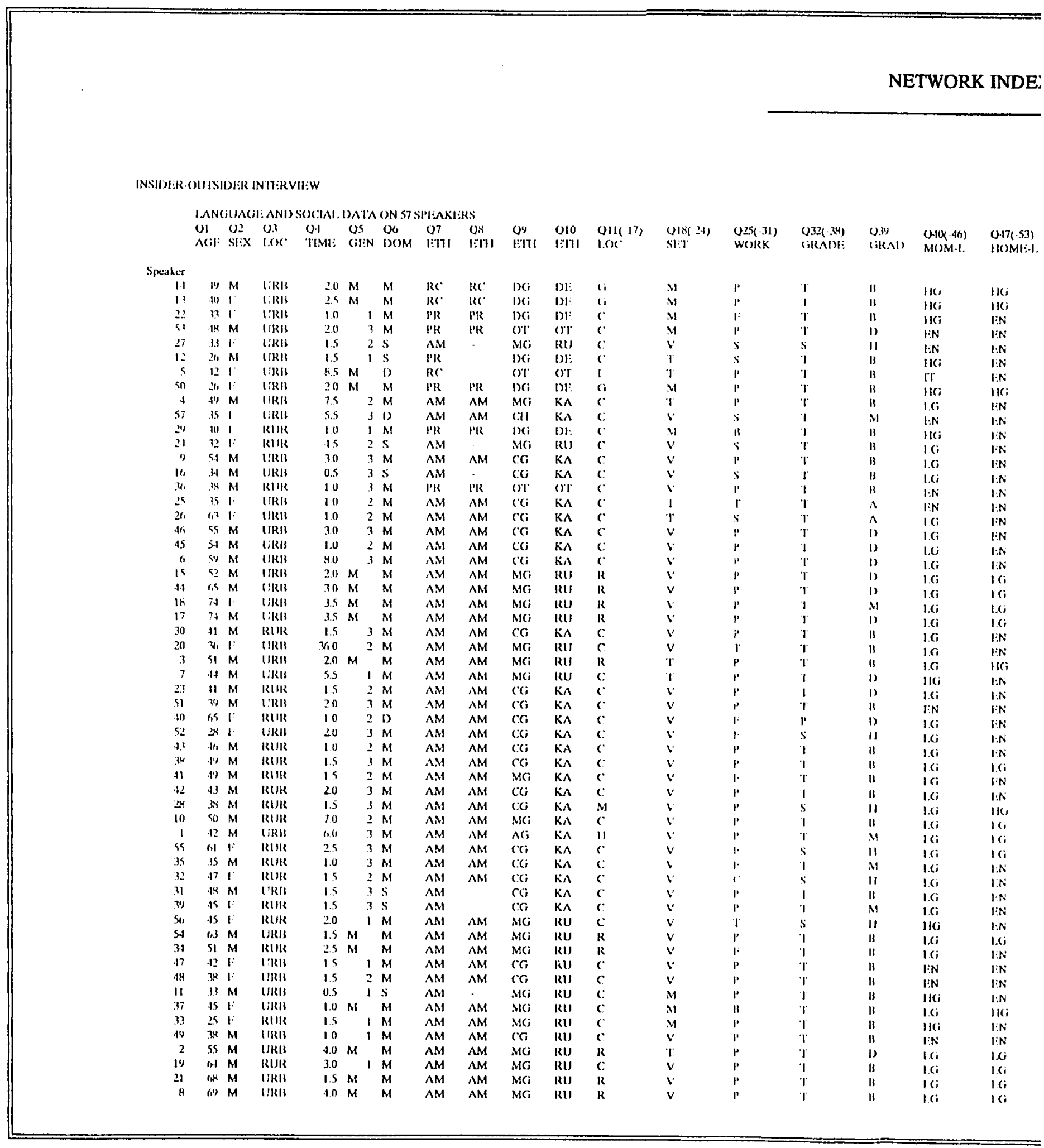




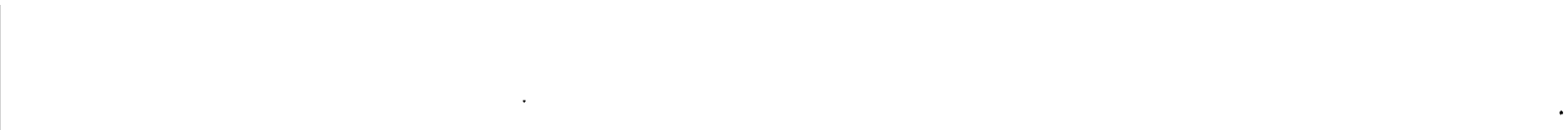


(ON 57 SIl:ANI:RS

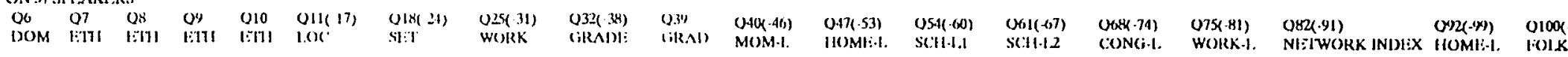

\begin{tabular}{|c|c|c|}
\hline (i) & $M$ & $I^{\prime}$ \\
\hline (1) & $\mathrm{H}$ & I' \\
\hline${ }^{\circ}$ & $M$ & i: \\
\hline${ }^{\circ}$ & $\mathbf{M}$ & $P^{\prime}$ \\
\hline C. & $v$ & $\mathrm{~s}$ \\
\hline${ }^{\circ}$ & 1 & $s$ \\
\hline I & $\gamma$ & " \\
\hline (i) & $M$ & " \\
\hline$c^{\circ}$ & 1 & $\mu$ \\
\hline$c$ & 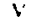 & s \\
\hline$c^{\circ}$ & $M$ & 11 \\
\hline$r$ & $v^{\prime}$ & 4 \\
\hline C: & $v^{\prime}$ & $l^{\prime}$ \\
\hline c: & $v$ & $s$ \\
\hline$\sigma^{\circ}$ & 1 & I' \\
\hline$c^{\circ}$ & 1 & 1 \\
\hline$c$ & $\boldsymbol{r}$ & $s$ \\
\hline$C$ & $v$ & $\mu$ \\
\hline$c$ & $v$ & $r$ \\
\hline$c^{\circ}$ & $v$ & $\mu$ \\
\hline R & $v^{\prime}$ & ' \\
\hline 18 & $v$ & I' \\
\hline R & $v$ & $I^{\prime}$ \\
\hline R & $v$ & $r^{\prime}$ \\
\hline c: & $v$ & $p^{\prime}$ \\
\hline c. & $v$ & $\mathbf{r}$ \\
\hline R & ${ }^{\prime} \boldsymbol{\prime}$ & 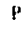 \\
\hline$c$ & 1 & $I^{\prime}$ \\
\hline${ }^{\circ}$ & $\therefore$ & $I^{\prime}$ \\
\hline$r$ & $v$ & $P^{\prime}$ \\
\hline c: & $v^{\prime}$ & 1 \\
\hline $6:$ & $v$ & 1 \\
\hline$c^{\circ}$ & $v$ & 1 \\
\hline$c$ & $v$ & $\mu$ \\
\hline c & $v$ & 1. \\
\hline$c$ & $v$ & $i$ \\
\hline$M$ & $v$ & $1^{*}$ \\
\hline$c$ & $v$ & $f^{\prime}$ \\
\hline 11 & $V$ & $1^{2}$ \\
\hline$c$ & $v$ & 1. \\
\hline$c$ & $v$ & 1. \\
\hline${ }^{c}$ & $\checkmark$ & I \\
\hline${ }^{\circ}$ & $v$ & r' \\
\hline$c$ & $v$ & J' \\
\hline $\mathrm{C}^{\prime}$ & $v$ & 1 \\
\hline " & $v$ & $1^{\circ}$ \\
\hline BR & $v$ & 1 \\
\hline c & $v^{\prime}$ & $P^{\prime}$ \\
\hline C. & $v$ & I' \\
\hline C: & $M$ & $1^{\prime \prime}$ \\
\hline c & $N$ & B \\
\hline${ }^{\circ}$ & $M$ & " \\
\hline c & $v^{\prime}$ & $1^{\prime}$ \\
\hline R & 1 & $\mu^{\prime}$ \\
\hline C & $v$ & $\mathrm{p}$ \\
\hline R & $v$ & J' \\
\hline & $v$ & $p^{\prime}$ \\
\hline
\end{tabular}

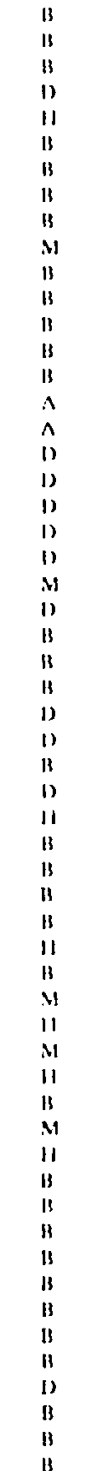

\begin{tabular}{|c|c|c|}
\hline He, & $116 ;$ & 116 \\
\hline $116 i$ & Hiki & $116 i$ \\
\hline HKi & $\mathbf{I}: \mathbf{N}$ & $I N$ \\
\hline I:N & IN & IN \\
\hline I:N & $\mathrm{LN}$ & IN \\
\hline IIC; & $\operatorname{IN}$ & IN \\
\hline $\mathrm{rr}$ & $I N$ & $1 N$ \\
\hline HISi & IIG; & $116 i$ \\
\hline I.Gi & $I N$ & $\mathrm{IIN}$ \\
\hline I:N & I:N & $\mathrm{I}: \mathrm{N}$ \\
\hline $116 i$ & $I N$ & $1: N$ \\
\hline $1.6 \mathrm{i}$ & $I N$ & $1: N$ \\
\hline I.G & $\mathrm{I}: \mathrm{N}$ & $I N$ \\
\hline I.Ci & $I: N$ & IN \\
\hline I:N & $I: N$ & $I: N$ \\
\hline $\mathrm{IIN}$ & $I N$ & $\mathrm{IN}$ \\
\hline I. $\mathrm{i}$ & $\mathrm{INN}$ & $I N$ \\
\hline $1.6 \mathrm{i}$ & INN & IN \\
\hline I. & $I: N$ & I:N \\
\hline ICi & $I N$ & IN \\
\hline $16 i$ & $16 i$ & $116 ;$ \\
\hline I.Ci & $16 i$ & $116 i$ \\
\hline $1 /(i$ & 1.6 & 116 \\
\hline I. $\mathrm{i}$ & $1.6 i$ & Jlsi \\
\hline 10 & I:N & $\mathrm{IN}$ \\
\hline $18 i$ & $\mathrm{IN}$ & $1 N$ \\
\hline $1 G i$ & $116 i$ & IICi \\
\hline IIC; & $1 . N$ & I.N \\
\hline I. $\mathrm{i}$ & $1: N$ & $1 . N$ \\
\hline EN & IN & $1 N$ \\
\hline I.Gi & $I: N$ & $I N$ \\
\hline 1.6 & $I: N$ & I. \\
\hline $16 \mathrm{i}$ & $I N$ & $I N$ \\
\hline $16 \mathrm{i}$ & 1.6 & IN \\
\hline I $\mathrm{Gi}$ & $I N$ & $1 N$ \\
\hline $1.6 j$ & I:N & I. $\mathrm{N}$ \\
\hline $1.6 \mathrm{i}$ & 116 & III \\
\hline I. $\mathrm{i}$ & 16 & $1 N$ \\
\hline I $\mathrm{Ci}$ & 16 & $1 \mathrm{~N}$ \\
\hline I $i$ & $16 i$ & $1 \cdot N$ \\
\hline I.6j & $I: N$ & IN \\
\hline I.Ci & $1 N$ & IN \\
\hline I. G & $I N$ & $1 \mathrm{~N}$ \\
\hline $16 \mathrm{i}$ & $1: N$ & $1 N$ \\
\hline IIC; & $I N$ & $I N$ \\
\hline I.G & 1.6i & 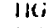 \\
\hline I. $;$ & $I: N$ & IN \\
\hline $\mathrm{INN}$ & $I N$ & $I N$ \\
\hline $\mathbf{I}: \mathbf{N}$ & $\mathrm{I}: \mathrm{N}$ & $\mathrm{I}: \mathrm{N}$ \\
\hline IIK; & $\mathrm{IIN}$ & I:N \\
\hline $16 i$ & $116 i$ & $I N$ \\
\hline IIC; & $I N$ & $\mathrm{IN}$ \\
\hline $1: N$ & $\mathrm{IIN}$ & $I: N$ \\
\hline $16 i$ & 10 & liki \\
\hline I. $i$ & I.ci & $I: N$ \\
\hline I.6i & 16 & 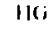 \\
\hline
\end{tabular}

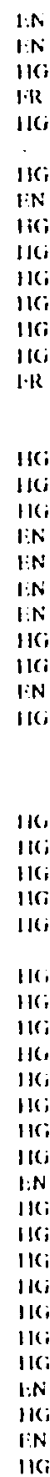

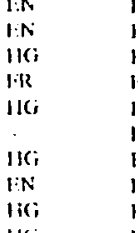

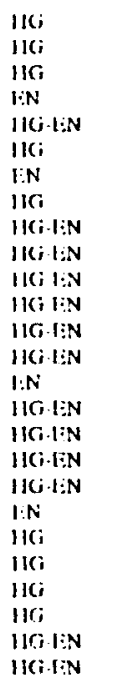

$\operatorname{IIGH}$ IIC I:N
IC I:N I:N

IN

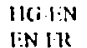
IICi I:N

I:N

IIN

IIGili:
IIGive

IIG II:N

IIC

I:N

I:N

I.G.11G IN $\quad=1+1+0+1+1+1+1$

I. i. IIU.I.N $\quad A=0+1+1+1+1$

I. j.ili.liN $+=0+1+1+1+1$

IGIIGIEN $\quad 1=0+1+1+1+1$

I.CIILII:N $\quad t=0+1+1+1+1$

HCi.1:N

I.G $1: \mathrm{N}$

4

$+=0+1+1+1+1$

$4=1+1+0+1+1$

I.G.IITIIIN $\quad t=1+1+0+1+1$

hici

IISi I:N

IICi.j:

III IN

$\operatorname{ma} \cdot \mathrm{lin}$

$t=1+1+0+1+1$
$4=1+1+1+0+1$

IIGi-I:N

$t=1+1+1+1+1$

I:N

$i_{N}$

JIGi-i:N

IIGitin

IIGi I:N

I:N

1.6.1.Y

$5=1+1+1+1+$

$5=1+1+1+1+1$

$S=1+1+1+1+1$

$s=1+1+1+1+1$

IiN

$s=1+1+1+1+1$

$116 i-1 \mathrm{~N}$

IICi

I.

$S=1+1+1+1+1$

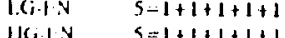

licillid:N $5=1+1+1+1+1$

I.GIIIIEN $5=1+1+1+1+1$

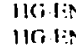

IIG.ISN

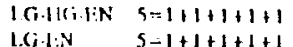

I.G.T.N

IICi-1in
I.G. i

I. $\mathrm{i} .1 . \mathrm{V}$

$5=1+1+1+1+1$

$5=1+1+1+1+1$

$5=1+1+1+1+1$

$\operatorname{lil}(\mathrm{i}-\mathrm{I}$

$S=1+1+1+1+1$

l.G.1.

$S=1+1+1+1+$

$s=1+1+1+1+1$

ligis
$116.1 \mathrm{y}$

$5:=1+1+1+1+$

IIG.

$S=1+1+1+1+1$
$5=1+1+1+1+1$

$\operatorname{licili}$

$5=1+1+1+1+$

HIC

lligi

IIGi. N
IIG

$5=1+1+1+1+1$

LG-LICj-LNS $\quad s=1+1+1+1+1$

IIG.I:N

I.Cillli-1

$S=1+1+1+1+$

Gatigitin $\quad s=111+1+1+1$

IIC;

l.G.liti.in

$s=1+1+1+1+1$ 



\begin{tabular}{|c|c|c|c|c|c|c|c|c|c|c|c|c|}
\hline $\begin{array}{l}\text { U.i" } \\
\text { (ikA1) }\end{array}$ & $\begin{array}{l}(0.40(46) \\
\text { N()M-1. }\end{array}$ & $\begin{array}{l}0.47(.53 i \\
110 \mathrm{Mt}:-1 .\end{array}$ & $\begin{array}{l}05+(\cdot+2) \\
\sin (1-1.1\end{array}$ & $\begin{array}{l}0,11(-67) \\
S(11.12\end{array}$ & $\begin{array}{l}\operatorname{Ues}(-74) \\
\operatorname{coN}(j-1 .\end{array}$ & $\begin{array}{l}\text { o75x.81) } \\
\text { wokk.1. }\end{array}$ & $\begin{array}{l}\text { O82(-91) } \\
\text { Ni:IWOKK INI)IiX }\end{array}$ & $\begin{array}{l}\text { ON(-.9\%) } \\
\text { HOML-1. }\end{array}$ & $\begin{array}{l}0100(-106) \\
\text { li(01KS-I. }\end{array}$ & $\begin{array}{l}\text { O107(-113) } \\
\text { CON(i-1. }\end{array}$ & $\begin{array}{l}0114(-120) \\
\text { scill. }\end{array}$ & $\begin{array}{l}\text { UILI } \\
\text { ITRAI }\end{array}$ \\
\hline 13 & 116 & II) & 116 & IN & IIG & $116 \cdot 1 \mathrm{~N}$ & $1=0+0+1+0+0$ & the & $116 ;$ & He, & I:N.IIC & IEN \\
\hline 11 & IKi & $116 i$ & $11 \mathrm{Ci}$ & $I: N$ & $110 i$ & $11(\mathrm{i} I \mathrm{~N}$ & $1=0+0+1+0+0$ & IICi & $116 i$ & IIKi & IIN.IIG & I:N \\
\hline 13 & 116 & $\mathrm{IEN}$ & $I: N$ & $116 ;$ & 119 & $M G I I N$ & $1=0+0+1+0+0$ & IEN & Hoi & IIGi & I:N.IIGi & IN \\
\hline 1) & $1: \mathrm{N}$ & $I: N$ & I:N & I:R & $I: N$ & $\mathrm{I}: \mathrm{N}$ & $1=0+0+1+0+0$ & F:N & $\mathrm{IiN}$ & HiN & I:N.TRK & $\mathrm{I}: \mathrm{N}$ \\
\hline 11 & I:N & I:N & I:N & $\mathrm{IIC}$ & $I I C ; .1 \leqslant N$ & I:N & $1=0+1+0+0+0$ & LEN & liN & $\operatorname{tiN}$ & I:N-HG & LN \\
\hline 13 & $11 \mathrm{Ci}$ & $\mathrm{I}: \mathrm{N}$ & I:N & & $116 i$ & IMIIIN & $1=1+0+0+0+0$ & ISN & $116 \mathrm{i}$ & IICIIIN & EN-HG & INN \\
\hline B & $\mathrm{rr}$ & IN & $I N$ & 116 & I:N & I:N I:TR & $1=1+0+0+010$ & $\mathrm{IEN}$ & $\mathrm{Ir}$ & $\mathrm{IEN}$ & l:N.FR & I:N \\
\hline is & $116 i$ & 136 & $\mathrm{HCi}$ & $1: N$ & $116 i$ & IIG in & $2=0+n+1+1+0$ & IICi & $116 i$ & Illi & IIN.IIC; & $\mathbf{H N}$ \\
\hline 3 & I.G & $I: N$ & IiN & $116 ;$ & $11 C i \cdot I: N$ & I:N & $2=0+1+0+0+1$ & $I: N$ & I.Gi & IIG I-INN & INN-ITR & II:N \\
\hline$M$ & $\mathbf{I}: \mathrm{N}$ & $I: N$ & $I: N$ & $11 C_{i}$ & $11 K i \cdot 1: N$ & $\mathrm{I}: \mathrm{N}$ & $2=0+1+0+0+1$ & I:N & I.G-H:N & IIN & I:N.HO & IIN \\
\hline 11 & $11 \mathrm{Ki}$ & $I N$ & I:N & $116 i$ & $11 C i 1: N$ & $11 G ; 1: N$ & $2-1+0+0+1+0$ & IIC I I:N & 116 & I:N & IIN.IIG & UN \\
\hline 11 & I 6 & I:N & $I: N$ & He; & $H C r \cdot I N$ & $11 G ; 1: N$ & $x=0+1+0+1+1$ & $1: N$ & I.r.PN & $\mathrm{EN}$ & IEN.IG.HG & EN \\
\hline "3 & 1.6 & $1: N$ & $I: N$ & 116 & $11 G+1: N$ & IICIIIN & $3=0+1+1+0+1$ & IIN & I.6i & IIT & I!N-IG-IIG & $\mathrm{VIN}$ \\
\hline 13 & 1.6i & $I: N$ & $I: N$ & 116 & $11 C i-1: N$ & IKGICI-1:N & $.3=0+1+1+1+0$ & L.(j-I:N & $1, c i$ & $\| K$ IIIN & LEN-L,Ci-IIG & LEN \\
\hline 11 & IIN & $I . N$ & $I: N$ & $1 \cdot k$ & $\mathrm{l}: \mathrm{N}$ & $I: N$ & $3=1+0+1+1+0$ & IIN & $\mathrm{t}: \mathrm{N}$ & LiN & 1:N-11C; & IEN \\
\hline A & I:N & $\mathrm{YN}$ & $\mathrm{I}: \mathrm{N}$ & & HGIEN & $I: N$ & $3=1+1+0+0+1$ & IEN & $\mathrm{IiN}$ & IEN & EN & $\operatorname{tin}$ \\
\hline$\hat{\imath}$ & IC; & $I: N$ & IIN & & $11 C .1: N$ & IIN & $x=1+1+n+0+1$ & IIN & I.G-I:N & $\| \mathrm{N}$ & IIN & IIN \\
\hline 17 & 1.6 & IN & $I: N$ & $11 \mathrm{Ci}$ & $11 G \cdot F N$ & I.G.IIG.IiN & $4=0+1+1+1+1$ & EN & la & HG;.IIN & INN-LG-HG & EN \\
\hline (3) & I.G & $\mathrm{I}: \mathrm{N}$ & IN & $116 ;$ & $H K j \cdot l i N$ & I.CIIIUILN & $t=0+1+1+1+1$ & LEN & 1.6 & LiN & IEN-LC;.IIG & $\mathrm{EN}$ \\
\hline 1) & 1.ci & $1: N$ & $I N$ & $116 i$ & $I: N$ & 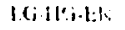 & $\therefore=0+1+!+1+1$ & $I: N$ & $1.6 i$ & $\|(C-l i N$ & IEN-ICC.JICi & $\mathrm{I}: \mathrm{N}$ \\
\hline 1) & $16 i$ & I. $\mathrm{i}$ & HIC; & liti & $\because ;$ & $1 C_{i}-11 C_{i} \mid \mathrm{N}$ & $1=0+1+1+1+1$ & I.G $\mathrm{i}-1: \mathrm{N}$ & I. 6 & HCi-I:N & I:N.I.C..HG & $\mathrm{FN}$ \\
\hline 11 & $1.6 i$ & $16 i$ & $116 ;$ & $1: N$ & !n & $! C_{1} ! G_{i} ! N$ & $1=0+1+1+1+1$ & I.G-116; & I.ritlo & $\mathrm{IIC} ;$ & IENGGAIIC & $\mathrm{IIN}$ \\
\hline$M$ & 1.6i & l.6; & 1116. & $1: N$ & $\therefore:$ & $1 i(j+1: N$ & $+=0+1+1+1+1$ & LCi-JI) & LCi-HICi & HIG; & IEN.LGHIS & EN \\
\hline 1) & $16 i$ & 16 & $116 ;$ & $1: N$ & $1 ! 6$ & $M G i \mid I_{N}$ & $4=0+1+1+1+1$ & $1.1 \mathrm{i}-11 \mathrm{Ci}$ & I.Gi & Hici & I:N.IG.G.]IG & IEN \\
\hline 11 & 16 & I:N & IN & 130 & $11 G \cdot 1 \cdot \mathrm{N}$ & ICIISN & $t=1+1+0+1+1$ & I:N & 1.6 & IEN & FE-IG.JG & EN \\
\hline 13 & in & IN & $I: N$ & $11 C_{i}$ & $H G \cdot I: N$ & ICAIICABN & $4=1+1+0+1+1$ & $\operatorname{IN}$ & I.G-HN & $\mathrm{INN}$ & ISARE-IIG & $\mathrm{IN}$ \\
\hline it & 1.6 & $\mathrm{HCi}$ & $116 i$ & $f: N$ & 110 & MKi.1:N & $f=1+1+1+0+1$ & $1.6 j-116 i$ & I.Ci.HCi & IICi & I:N.IIC; & IEN \\
\hline 1) & $116 ;$ & L:N & I.N & $116 ;$ & $11 C ; E N$ & IIGil:N & $f=1+1+1+1+1$ & I:N & $116 i$ & $\|(\mathbf{i} \cdot \mid: N$ & I:N-IIC & I:N \\
\hline 1) & 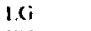 & $1: N$ & $1 N$ & & IIC IIN & $I: N$ & $5=1+1+1+1+1$ & $\operatorname{liN}$ & $1 .(\mathrm{i} \cdot \mathrm{L}: \mathrm{N}$ & $\mathrm{I}: \mathrm{N}$ & I:N & LiN \\
\hline 13 & $I: N$ & IN & $I N$ & & IN & I:N & $5=1+1+1+1+1$ & $1 \mathrm{~N}$ & $1: N$ & EN & EN & $\mathrm{liN}$ \\
\hline 1) & $16 i$ & $\mathrm{IN}$ & $I: N$ & & $116 ; 1: N$ & $\mathrm{I}: \mathrm{N}$ & $S=1+1+1+1+1$ & I:N & 1.6i & $\mathrm{riN}$ & IEN & I:N \\
\hline 11 & 1.6 & $\mathrm{I}: \mathrm{N}$ & lin & 146 & IKG & $I: N$ & $S=1+1+1+1+1$ & I:N & I.Gil:N & IILiLEN & IIN & $t: N$ \\
\hline 13 & I. $6 \mathrm{i}$ & L:N & IN & $111 \mathrm{i}$ & IKi-liN & $1(i \cdot 1: N$ & $S=1+1+1+1+1$ & INN & 1.6 & $\mathrm{ISN}$ & $1: N \cdot 1 \cdot 7 R$ & LIN \\
\hline 11 & I.6i & 16 & $I \cdot N$ & $116 i$ & HCI IN & ICIIN & $S=1: 1+1+1+1$ & 1.6 & 1.6 & HCIEN & I:N.FR & LN \\
\hline 11 & 16 & IN & $I N$ & $110 i$ & $11(\mathrm{i}, \mathrm{N}$ & $\mathrm{I}: \mathrm{N}$ & $s=1+1+1+1+1$ & IIN & In & riN & IIN.TR & $\operatorname{IIN}$ \\
\hline 13 & 1.6 & $1: N$ & IN & $116 ;$ & $\| K \cdot .1 \mathrm{~N}$ & $16.1: N$ & $5-1+1+1+1+1$ & $\mathrm{t}: \mathrm{N}$ & L.G & liN & ENA.P.K & IEN \\
\hline 11 & $1.6 i$ & 116 & 116 & & IIKi & $I K, 1: N$ & $S=1+1+1+1+1$ & la; & 1.6 & 116 & $E N \cdot I t ;$ & LiN \\
\hline 11 & I.G & 16 & $1 \pi$ & 136 & $116,1: N$ & ICIIICIIN & $5-1+1+1+1+1$ & $1.1 i$ & 1.6 & $116.1 \mathrm{~N}$ & [iN.LOHC; & IEN \\
\hline$M$ & $16 i$ & 16 & IN & $116 \mathrm{i}$ & $116 ; 9 \div 1$ & ICIIIKIIIN & $s=1+1+1+1+1$ & $1: N$ & I.GHIN & IIG;I:N & BN.ICF.HC & $1: N$ \\
\hline 11 & 18 & 16 & $I N$ & $111 \mathrm{i}$ & $11 G \mathrm{HN}$ & 1G.1IGi.1:N & $s=1+1+1+1+1$ & I.6; & $1 . x$ & ItGi.IN & IENIGIBIG & I:N \\
\hline .11 & I.Ci & I:N & IN & ! 16 & $\|(;-1: N$ & I.CII:N & $S=1+1+1+1+1$ & LiN & $1,6 i$ & liN & LEN-L.G-HIG & L:N \\
\hline 11 & 1.6 & $I N$ & IN & 116, & $\| G ;-1 \equiv N$ & $M(-1 . N$ & $5=1+1+1+1+1$ & $\mathrm{I}: \mathrm{N}$ & I. & $116 \cdot 1: N$ & I:N.ICillG & ISN \\
\hline 11 & 16 & $I N$ & In & HKi & $116 ; 1: N$ & $1,19 \mathrm{~N}$ & $5=111+1+11 !$ & $\operatorname{liN}$ & I.Gi & $\mathrm{IEN}$ & EN.LGHG & IEN \\
\hline$M$ & $16 i$ & $1: N$ & IN & $116 i$ & $116 \cdot .13 !$ & $16-1: N$ & $5=1+1+1+1+1$ & $I I N$ & i.xi & IIGi.IEN & VENIG.JKi & $\operatorname{INN}$ \\
\hline 11 & IlGi & $1: N$ & $I: N$ & 116 & $\|(\mathbf{j} \cdot \mid \mathrm{EN}$ & $I: N$ & $S=1+1+1+1+1$ & LiN & $116 j$ & bN & EN & L:N \\
\hline B & 16 & eci & $11 k ;$ & $1: N$ & IIC; & $H G(H) N$ & $S=1+1+1+1+1$ & $1,(j-1)(i$ & $1.6+116 ;$ & 116 & LEN. I.R & I:N \\
\hline 11 & $16 i$ & $I N$ & $I N$ & $116 i$ & $116 ; \cdot 1 \leqslant N$ & I.Ci.IN & $5=1+1+1+1+1$ & $\operatorname{LiN}$ & I.G.hIC; & IIN & I:N.ITR & IN \\
\hline 13 & $I: N$ & IN & $I N$ & $11 c_{i}$ & $\| K$ II:N & IIG is: & $5:=1+1+1+1+1$ & IN & I.RiEN & IIG.FN & EN.HG & $\mathrm{VN}$ \\
\hline 13 & I:N & l:N & $1: N$ & $116 i$ & IIG ISN & $11 \mathrm{GIN}$ & $5=1+1+1+1+1$ & $\mathrm{INN}$ & I.G.FIN & I:N & IIN-IIG & R.N \\
\hline 13 & IIGi & l:N & I:N & 116 & 116 & IKit:N & $S=1+1+1+1+1$ & L:N & $116 ;$ & IIG-EN & EH.LIG & IN \\
\hline 13 & I.6i & 116 & I:N & 1K: & 116 & $1 K i: \mathrm{N}$ & $5=1+1+1+1+1$ & IICj-I:N & I.Ci-1) & lici & EN-IIG & EN \\
\hline 13 & Ili & In & $1 \cdot N$ & $116 i$ & 116 & IIKil:N & $S=1+1+1+1+1$ & IIG.IEN & 116 & Ilki & IE-IIG & $\mathrm{I}: \mathrm{N}$ \\
\hline 11 & $\mathrm{I}: \mathrm{N}$ & $\mathrm{IiN}$ & $I: N$ & $116 i$ & $I I C ; I N N$ & $11 C_{i} . \mathrm{N}$ & $5=1+1+1+1+1$ & IN & I.GitiN & rin & LNHG & LN \\
\hline 1) & 16 & $u_{i}$ & $H / C i$ & $\mathrm{IN}$ & 116 & $\|$ (G.\|l-LiN & $5=1+1+1+1+1$ & LG & i.c; & Ilc; & LAN-LG-HG & IEN \\
\hline is & $16 i$ & ici & $I N$ & 116 & HGiliN & $1.6 \cdot 116$ i.1:N & $S=1+1+1+1+1$ & I.G; & 1.6i & $\| G$ IIIN & LEN.LG.J]G & EN \\
\hline 13 & 16 & 16 & 116 & IN & IIC: & IIG I: & $5=111+111+1$ & $1 .(i .1)$ & 1.6 & Ilici & I:N-LG-1IG & $1: N$ \\
\hline B & 1,6 & 16 & IIfi & $116 i$ & $116 ;$ & I.Cilmi.l:N & $s=1+1+1+1+1$ & & i.ci & $i l(i-t i N$ & I:N-IG-HG & $\sqrt{4}$ \\
\hline
\end{tabular}


